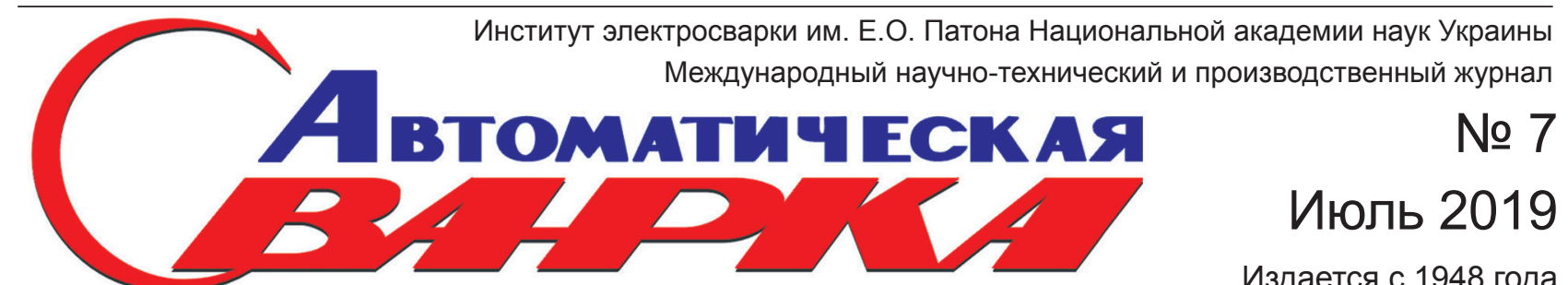

РЕДАКЦИОННАЯ КОЛЛЕГИЯ

Главный редактор Б.Е. Патон

Ученые ИЭС им. Е.О. Патона Д.т.н. С.И. Кучук-Яценко (зам. гл. ред.), д.Т.Н. В.Н. Липодаев (зам. гл. ред.),

Д.Т.н. Ю.С. Борисов,

Д.Т.Н. Г.М. Григоренко,

к.ф.--М.Н. А.Т. Зельниченко Д.Т.Н. В.В. Кныш,

д.Т.н. И.В. Кривцун, Д.Т.н. Ю.Н. Ланкин, Д.Т.Н. Л.М. Лобанов Д.Т.Н. В.Д. Позняков,

Д.Т.н. И.А. Рябцев, д.Т.Н. К.А. Ющенко

Т.В. Юштина (отв. секр.)

Ученые университетов Украины д.Т.Н. В.В. Дмитрик, НТУ «ХПИ», Харьков, д.Т.Н. В.В. Квасницкий,

НТУУ «КПИ им. Игоря Сикорского», Киев, К.Т.Н. Е.П. Чвертко

НТУУ «КПИ им. Игоря Сикорского», Киев,

Д.т.н. М.М. Студент, Физ.-механ. ин-т

им. Г.В. Карпенко НАНУ, Львов

Зарубежные ученые д.Т.н. Н.П. Алешин

МГТУ им. Н.Э. Баумана, Москва, РФ д.Т.н. Гуань Цяо

Ин-т авиационных технологий, Пекин, Китай д.Х.н. М. Зиниград Ун-т Ариэля, Израиль д.Т.н. В.И. Лысак

Волгоградский гос. техн. ун-т, РФ д-р инж. У. Райсген

Ин-т сварки и соединений, Аахен, Германия Д.Т.н. Я. Пилярчик

Ин-т сварки, Гливице, Польша д.Т.Н. Г.А. Туричин

С.-Петербургский гос. политехн. ун-т, РФ

Адрес редакции

ИЭС им. Е.О. Патона НАНУ

03150, Украина, Киев-150,

ул. Казимира Малевича, 11

Тел.: (38044) 200 6302, 2008277

Факс: (38044) 2008277

E-mail: journal@paton.kiev.ua

www.patonpublishinghouse.com

Учредители

Национальная академия наук Украины, ИЭС им. Е.О. Патона НАНУ,

МА «Сварка» (издатель)

Свидетельство о государственной регистрации КВ 4788 от 09.01.2001 ISSN 0005-111X

DOI: http://dx.doi.org/10.15407/as

Рекомендовано к печати редакционной коллегией журнала

Журнал входит в перечень утвержденных

Министерством образования и науки

Украины изданий для публикации трудов соискателей ученых степеней

За содержание рекламных материалов редакция журнала ответственности не несет

Цена договорная

Подписной индекс 70031

Издается ежемесячно

\title{
СОДЕРЖАНИЕ
}

\section{НАУЧНО-ТЕХНИЧЕСКИЙ РАЗДЕЛ}

Цыбулькин Г.А. Исследование импульсно-дуговых процессов при периодическом изменении вольт-амперных характеристик источника питания дуги

Красновский К., Хохлова Ю.А., Хохлов М.А. Влияние фрормы инструмента для сварки трением с перемешиванием на физико-механические свойства сварных соединений алюминиевого сплава EN AW 6082-T6

Костин В.А., Григоренко Г.М. Моделирование температурных полей, напряжений и деформаций в цилиндрических оболочках, полученных методом аддитивной технологии

Илюшенко В.М., Бондаренко А.Н., Лукьянченко Е.П., Майданчук Т.Б. Эфффективность применения присадочной металлопорошковой проволоки при TIG сварке меди.

Максимова С.В., Зволинский И.В. Плазменно-дуговая пайка стали 08кп с применением припоев системы $\mathrm{Cu}-\mathrm{Mn}-\mathrm{Ni}-\mathrm{Si}$

Левченко О.Г., Лукьяненко А.О., Демецкая О.В. Влияние состава связующего покрытия электродов на токсичность сварочных аэрозолей .

\section{ПРОИЗВОДСТВЕННЫЙ РАЗДЕЛ}

Ющенко К.А., Яровицын А.В., Червяков Н.О., Звягинцева А.В., Волосатов И.Р., Хрущов Г.Д. Оценка кратковременных механических свойств соединения трудносвариваемых никелевых жаропрочных сплавов типа ЖС6

Позняков В.Д., Гайворонский А.А., Клапатюк А.В., Шишкевич А.С, Ящук В.А. Порошковая проволока для восстановления наплавкой изношенных поверхностей железнодорожных колес

Марченко А.Е. Факторы риска и критерии пожаро- и взрывоопасности при измельчении ферросплавов

\section{ХРОНИКА}

Всеукраинский конкурс студенческих научных работ

по направлению «Сварка»

Научно-техническое сотрудничество: ИЭС-Турбоатом ............... 61

Семинар «Автоматизация и механизация сварки» .

Международная конференция «Инновационные техно-

логии и инжиниринг в сварке и родственных процессах -

PolyWeld 2019»

Конфреренция «Материалы для сварки, наплавки, нанесе-

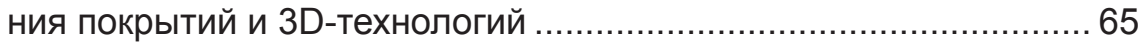

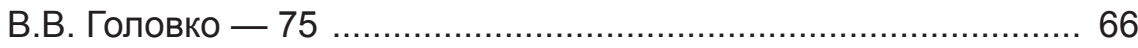

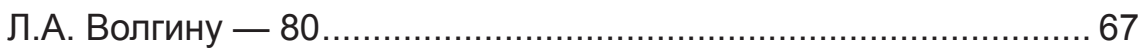




\section{Автоматичне Зварювання}

Видається 12 разів на рік з 1948 р.

\section{Головний редактор Б.є. Патон 3MICT}

\section{НАУКОВО-ТЕХНІЧНИЙ РОЗДІЛ}

Цибулькін Г.О. Дослідження імпульсно-дугових процесів при періодичній зміні вольт-амперних характеристик джерела живлення дуги .............. Красновський К., Хохлова Ю.А., Хохлов М.А. Вплив форми інструменту для зварювання тертям з перемішуванням на фрізико-механічні властивості зварних з'єднань алюмінієвого сплаву EN AW 6082-T6

Костін В.А., Григоренко Г.М. Моделювання температурних полів, напруг та деформацій у циліндричних оболонках, отриманих методом адитивної технології

Ілюшенко В.М., Бондаренко А.М., Лук'янченко Є.П., Майданчук Т.Б. Ефективність застосування присадних металопорошкових дротів при TIG зварюванні міді

Максимова С.В., Зволінський І.В. Плазмово-дугове паяння сталі 08кп із застосуванням припоїв системи $\mathrm{Cu}-\mathrm{Mn}-\mathrm{Ni}-\mathrm{Si}$

Левченко О.Г., Лук'яненко А.О., Демецька О.В. Вплив складу зв'язуючого покриття електродів на токсичність зварювальних аерозолів

\section{ВИРОБНИЧИЙ РОЗДІЛ}

Ющенко К.А., Яровіцин О.В., Черв'яков М.О., Звягінцева А.В., Волосатов І.Р., Хрущов Г.Д. Оцінка короткочасних механічних властивостей з'єднання важкозварювальних нікелевих жароміцних сплавів типу ЖС6

Позняков В.Д., Гайворонський О.А., Клапатюк А.В., Шишкевіч О.С, Ящук В.А. Порошковий дріт для відновлення наплавленням зношених поверхонь залізничних коліс

Марченко А.Ю. Фактори ризику і критерії пожежота вибухонебезпечності при подрібненні феросплавів

\section{ХРОНІКА}

Всеукраїнський конкурс студентських наукових робіт за напрямом «Зварювання»

Науково-технічне співробітництво:

IE3-Турбоатом

Семінар «Автоматизація та механізація зварю-

вання»

Міжнародна конфреренція «Інноваційні технології та інжиніринг в зварюванні та споріднених процеcax - PolyWeld 2019» .... 64

Конференція «Матеріали для зварювання, наплавлення, нанесення покриттів та 3D-технологій» .......6 65

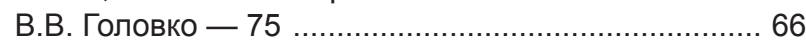

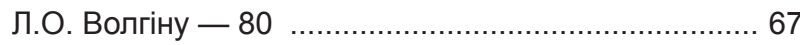

Журнал «Автоматичне зварювання» видається англійською мовою під назвою «The Paton Welding Journal» Адреса редакції

03150, Україна, м. Київ-150, вул.Казимира Малевича, 11 IEЗ ім. Є.О. Патона НАН України

Тел./факс: (38044) 200-82-77, 200-63-02 E-mail: journal@paton.kiev.ua www.patonpublishinghouse.com

\section{Avtomaticheskaya Svarka (Automatic Welding)}

Published 12 times per year since 1948

\author{
Editor-in-Chief B.E. Paton \\ CONTENTS \\ SCIENTIFIC AND TECHNICAL
}

Tsybulkin G.A. Study of pulsed arc processes, generated by periodic switching of volt-ampere characteristics of the arc power source ..................................... 3 Krasnovski K., Khokholova Yu.A., Khokholov M.A. Influence of the shape of the tool for firction stir welding on physico-mechanical properties of the zones of welds of alminium alloy EN AW 6082-T6 Kostin V. A., Grigorenko G. M. Modelling of temperature fields, stresses and deformations in cylinder casings

produced by additive manufacturing method

Ilyushenko V.M., Bondarenko A.N., Lukyanchenko E.P., Maydanchuk T.B. Efficiency of application of filler metal-cored wire in TIG welding of copper ...... 24 Maksymova S.V., Zvolinskyy I.V. Braze alloys of Cu-Mn-Ni-Si system and plasma-arc brazing of 8KP (boiling) steel

Levchenko O.G., Lukianenko A.O., Demetskaya O.V. Influence of the composition of electrode coating binder on toxicity of welding fumes

\section{INDUSTRIAL}

Yushchenko K.A., Yarovitsyn A.V., Chervyakov N.O., Zvyagintseva A.V., Volosatov I.R., Khrushchov G.D. Peculiarities of evaluation of short-term mechanical properties of a joint of difficult-to-weld nickel hightemperature alloys of ZhS6 type ............................... 38 Poznyakov V.D., Gaivoronskiy A.A., Klapatyuk A.V., Shishkevich A.S., Yashchuk V.A. Flux-cored wire for restoration surfacing of worn surfaces of railway wheels

Marchenko A.E. Risk factors, and criteria of fire and explosion safety at ferroalloy grinding

\section{NEWS}

All-Ukrainian Competition of Student Scientific Works in «Welding» Area ................................................... 60

Scientific-Technical Cooperation: PWI-Turboatom ...... 61 Seminar on «Welding Automation and Mechanization» 62

International Conference «Innovation Technologies and Engineering in Welding and Related Processes PolyWeld 2019» 64 Conference «Consumables for Welding, Surfacing, Coating and 3D Technologies» ................................ 65

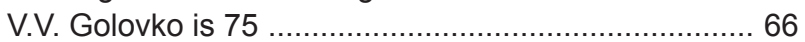

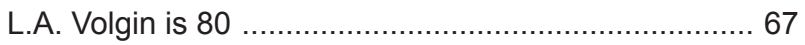

«Avtomaticheskaya Svarka» (Automatic Welding) journal is republished
in English under the title «The Paton Welding Journal»
The E. O. Paton Electric Welding Institute of the NAS of Ukraine,
11 Kazimir Malevich Str., 03150, Kyiv, Ukraine
Tel./Fax: (38044) 200-82-77, 200-63-02
E-mail: journal@paton.kiev.ua
www.patonpublishinghouse.com




\title{
ИССЛЕДОВАНИЕ ИМПУЛЬСНО-ДУГОВЫХ ПРОЦЕССОВ ПРИ ПЕРИОДИЧЕСКОМ ИЗМЕНЕНИИ ВОЛЬТ-АМПЕРНЫХ ХАРАКТЕРИСТИК ИСТОЧНИКА ПИТАНИЯ ДУГИ
}

\begin{abstract}
Г.А. Цыбулькин
ИЭС им. Е.О. Патона НАН Украины. 03150, г. Киев, ул. Казимира Малевича, 11. E-mail: office@paton.kiev.ua

Рассматриваются импульсно-дуговые процессы, осуществляемые путем периодического переключения вольт-амперных характеристик источника питания дуги, имеющих различную крутизну. При этом сама коммутация указанных характеристик осуществляется не принудительно, а автоматически на основе информации о текущем состоянии системы «источник питания-дуга». Основная цель - выяснить насколько эффективен указанный способ импульсно-дуговой сварки плавящимся электродом в среде защитного газа. В статье приводятся результаты теоретических исследований и компьютерного моделирования автоколебательных процессов, протекающих в рассматриваемой системе. Выведена формула для предварительной оценки частоты следования импульсов сварочного тока. Варьируя значением определенного параметра, фигурирующего в этой формуле, можно задавать желаемую частоту следования указанных импульсов. Библиогр. 9, рис. 7.
\end{abstract}

Ключевые слова: импульсно-дуговая сварка, плавящийся электрод, коммутация вольт-амперных характеристик, компьютерное моделирование, частота следования импульсов сварочного тока

Импульсный процесс дуговой сварки плавящимся электродом в среде защитного газа может быть осуществлен различными способами [1-7]. Наиболее эффективными в настоящее время считаются два способа:

- путем подачи на дугу дополнительного напряжения от специального генератора импульсов, подключенного параллельно основному источнику питания дуги;

- периодическим переключением вольт-амперных характеристик источника питания дуги, имеющих различную крутизну.

Второй способ представляется особенно привлекательным в том отношении, что содержит потенциальные возможности осуществления импульсного режима сварки не только за счет принудительной коммутации вольт-амперных характеристик источника питания дуги, как это реализовано в работе [5]. Можно, например, ввести в систему «источник питания-дуга» специальную обратную связь, обеспечивающую коммутацию указанных характеристик автоматически на основе информации о текущем состоянии данной системы.

Предполагается, что такое решение позволит получить новые полезные свойства, не присущие системе импульсно-дуговой сварки с принудительной коммутацией вольт-амперных характеристик.

Заметим, что системы, работа которых основана на принципе изменения ее параметров в зависимости от текущего состояния системы, в теории управления относятся к классу систем с переменной структурой [8].

(C) Г.А. Цыбулькин, 2019
В настоящей статье будут рассмотрены импульсно-дуговые процессы, устанавливающиеся в системе с автоматической коммутацией вольт-амперных характеристик. Цель - выяснить насколько эффективен указанный способ импульсно-дуговой сварки.

На рис. 1 схематически изображена система «источник питания - дуга», включающая источник питания дуги $(S P)$ с двумя вольт-амперными характеристиками, крутизна которых $S_{1}$ и $S_{2}$ различна, и сварочный контур $(W C)$ с плавящимся электродом. Кроме того, введено логическое переключающее устройство $(L S D)$, которое, в зависимости от текущего состояния системы, характеризуемого выходным напряжением источника питания $u_{s}=u_{s}(t)$, подключает к сварочному контуру либо электрическую цепь с параметром $S_{1}$, либо с параметром $S_{2}$, т. е. изменяет структуру самой системы по определенному закону.

Математическое описание системы. На основе схемы, представленной на рис. 1, и известных свойств саморегулирования дуги [9] составим уравнения, описывающие динамические процессы, протекающие в рассматриваемой системе:

$$
\left.\begin{array}{c}
u_{x}=u_{s}+S i, \\
u_{s}=u_{a}+(L D+R) i, \\
u_{a}=u_{0}+E l+S_{a} i, \\
l=H-h_{0}-\frac{1}{D}\left(v_{e}-v_{m}\right), \\
v_{m}=M i .
\end{array}\right\},
$$




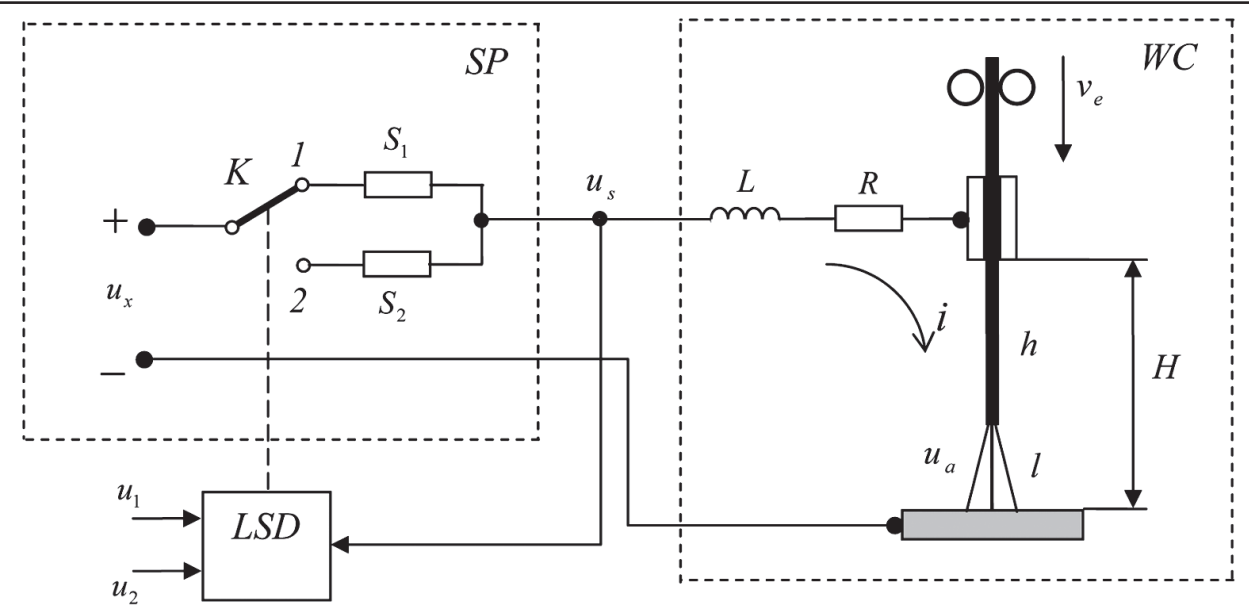

Рис. 1. Схема системы «источник питания-дуга» (обозначения см. в тексте)

где $u_{x}=$ const - напряжение холостого хода; $i=$ $=i(t)-$ сварочный ток; $S=\left|\partial u_{s} / d i\right|-$ абсолютное значение крутизны выходной вольт-амперной характеристики, равное $S_{1}$ или $S_{2}$ в зависимости от положения переключателя $K ; u_{a}=u_{a}(t)$ - напряжение на дуге; $L$ - индуктивность сварочной цепи; $R$ - суммарное сопротивление подводящих проводов, вылета электрода и скользящего контакта в мундштуке горелки; $u_{0}$ - сумма приэлектродных падений напряжений; $S_{a}=\left|\partial u_{d} / d i\right|-$ абсолютное значение крутизны вольт-амперной характеристики дуги; $E$ - напряженность электрического поля

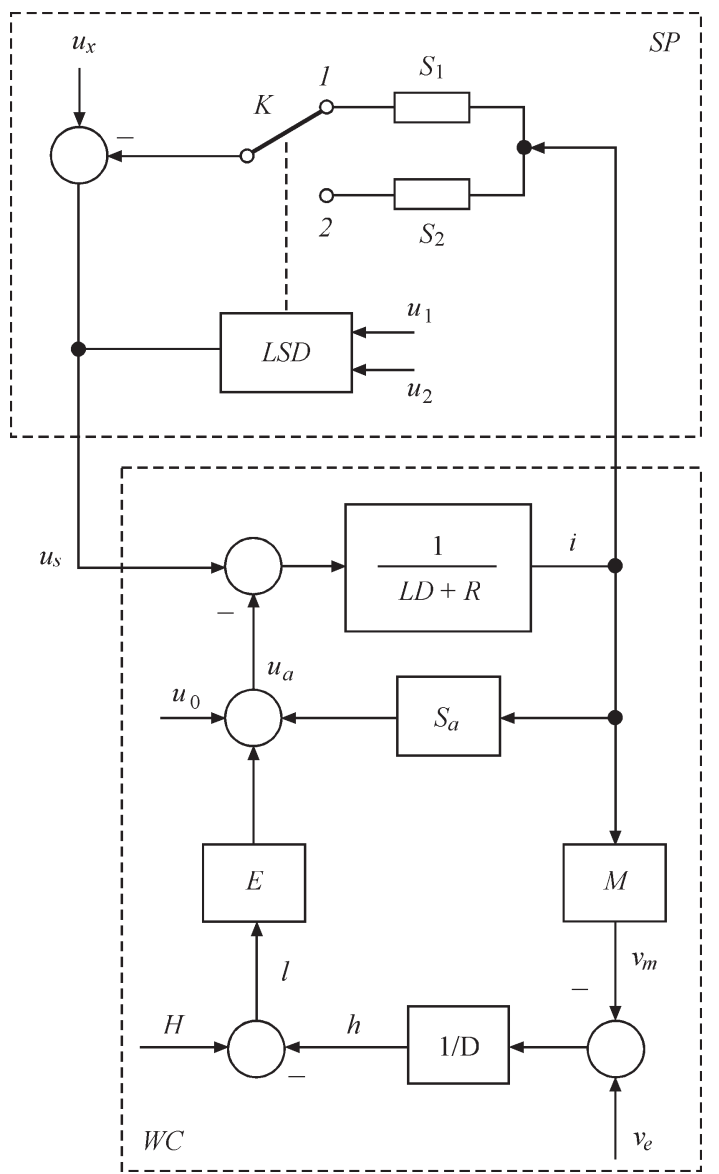

Рис. 2. Структурная схема системы «источник питаниядуга» с переменной структурой (описание см. в тексте) в столбе дуги; $l=l(t)$ - длина дуги; $H=\mathrm{const}-$ расстояние между торцом токоподводящего мундштука и свободной поверхностью сварочной ванны; $h_{0}, h=h(t)$ - начальное и текущее значения вылета электрода; $v_{e}=$ const, $v_{m}=v_{m}(t)-$ скорости подачи и плавления электрода, соответственно; $M=d v_{m} / d i-$ крутизна токовой характеристики плавления электрода; $D=d / d t$ - оператор дифференцирования; $t$ - текущее время.

При составлении уравнений (1) использована некоторая идеализация относительно реальных вольт-амперных характеристик источника сварочного тока, аппроксимировав их линейными функциями. Графическая интерпретация системы уравнений (1) в виде структурной схемы изображена на рис. 2. Сварочный контур $W C$, входящий в эту систему, с точки зрения теории автоматического управления представляет собой замкнутую систему с естественной отрицательной обратной связью по скорости плавления электрода $v_{m}$, которая обеспечивает самостабилизацию (саморегулирование) длины дуги $l(t)$ при заданной скорости $v_{e}$ и заданном расстоянии $H$, а релейная обратная связь по напряжению $u_{s}(t)$ обеспечивает автоматическое переключение структуры системы.

Закон переключения запишем в виде:

$$
S=\left\{\begin{array}{ll}
S_{1}, & \left(u_{s} \leq u_{1}, D u_{s}<0\right), \\
S_{2}, & \left(u_{s} \geq u_{2}, D u_{s}>0\right),
\end{array} S_{1}<S_{2},\right.
$$

где $u_{1}$ и $u_{2}$ - пороговые значения $u_{s}(t)$.

Приведем систему уравнений (1) с учетом выражения (2) к одному дифференциальному уравнению

$$
\left(T_{L}^{2} D+T D+1\right) u_{s}(t)=g,
$$

в котором $T_{L}, T$ - коэффициенты, определяемые соотношениями

$$
T_{L}^{2}=\frac{L}{E M}, \quad T= \begin{cases}T_{1}, & \left(S=S_{1}\right), \\ T_{2}, & \left(S=S_{2}\right),\end{cases}
$$


где

$$
T_{1}=\frac{S_{1}+S_{a}+R}{E M}, T_{2}=\frac{S_{2}+S_{a}+R}{E M},
$$

а правая часть имеет вид

$$
g= \begin{cases}g_{1}, & \left(S=S_{1}\right), \\ g_{2}, & \left(S=S_{2}\right),\end{cases}
$$

где

$$
g_{1}=u_{x}-S_{1} \frac{v_{e}}{M}, g_{2}=u_{x}-S_{2} \frac{v_{e}}{M} .
$$

Из выражений (4), (5) видно, что коэффициент $T$, фигурирующий в уравнении (3), и правая часть этого уравнения $g$ изменяются скачком при переключении системы с одной характеристики на другую, т. е. при переключении связей между элементами системы. Что касается величины $T_{L}^{2}$, то она, согласно (4), постоянна и в большинстве практических случаев значительно меньше $T$, так как $L<<\left(S+S_{a}+R\right)^{2} / E M$. Это позволяет вместо уравнения (3) в дальнейшем использовать редуцированное (укороченное) уравнение

$$
(T D+1) u_{s}(t)=g .
$$

Пороговые значения $u_{1}$ и $u_{2}$, входящие в выражение (2), выберем, исходя из следующих условий:

$$
u_{1}=g_{2}+\xi, u_{2}=g_{1}-\xi,
$$

где $\xi>0$ - некоторая величина, выбираемая из технологических соображений.

Для того чтобы проследить за ходом динамического процесса, описываемого уравнением (6), рассмотрим последовательно два процесса, подчиняющихся двум различным дифференциальным уравнениям $\left(T_{1} D+1\right) u_{s}(t)=g_{1}$ и $\left(T_{2} D+1\right) u_{s}(t)=g_{2}$.

Начнем с момента, когда переключающий элемент $K$ установлен в положение 1 , как показано на рис. 1 . На этом этапе сварочный процесс протекает согласно дифференциальному уравнению $\left(T_{1} D+1\right) u_{s}(t)=g_{1}$. С учетом начального условия $u_{s}(0)=u_{s 0}$ решение этого уравнения примет следующий вид:

$$
u_{s}(t)=\left(u_{s 0}-g_{1}\right) \exp \left(-\frac{t}{T_{1}}\right)+g_{1}
$$

(начальному условию $u_{s}(0)=u_{s 0}$ на рис. 3 соответствует точка $P$ ).

Согласно (8) напряжение $u_{s}(t)$ с ростом $t$ возрастает и стремится к своему установившемуся значению $g_{1}=u_{x}-S_{1} v_{e} M^{-1}$. Но в момент времени $t_{1}$, когда $u_{s}(t)$ становится равным пороговому значению $u_{2}=g_{1}-\xi$, происходит согласно закону (2) переключение системы с характеристики 1 на характеристику 2 (переключатель $K$ на рис. 1 устанавливается при этом в положение 2). Рабочая точка рассматриваемого динамического процес- са (см. рис. 3) «скачком» переходит из точки $a$ в точку $b$. При этом напряжение $u_{s}$, равное $u_{2}$, остается неизменным, но происходит скачкообразное уменьшение сварочного тока $i=i(t)$. На этом первый этап заканчивается.

На втором этапе динамический процесс подчиняется дифференциальному уравнению

$$
\left(T_{2} D+1\right) u_{s}(t)=g_{2} \text {. }
$$

Решение этого уравнения с учетом начального условия $u_{s}\left(t_{1}\right)=u_{2}$ принимает вид

$$
u_{s}(t)=\left(u_{2}-g_{2}\right) \exp \left(-\frac{\left(t-t_{1}\right)}{T_{2}}\right)+g_{2} .
$$

Согласно (9) напряжение $u_{s}(t)$, начиная с момента времени $t_{1}$, будет убывать, стремясь к установившемуся значению $g_{2}=u_{x}-S_{2} v_{e} M^{-1}$. Как только $u_{s}(t)$ становится равным $u_{1}=g_{2}+\xi$, происходит в соответствии с (2) переключение системы с характеристики 2 на характеристику 1 . При этом рабочая точка «скачком» переходит из точки $c$ в точку $d$. Соответственно, «скачком» увеличивается сварочный ток $i=i(t)$.

Теперь напряжение $u_{s}(t)$ снова начнет расти в соответствии с уравнением

$$
u_{s}(t)=\left(u_{1}-g_{1}\right) \exp \left(-\frac{\left(t-t_{2}\right)}{T_{2}}\right)+g_{1},
$$

где $t_{2}$ - момент времени, когда $u_{s}(t)=u_{1}$. Увеличение $u_{s}(t)$ будет продолжаться до тех пор, пока не достигнет порога $u_{2}$ в точке $a$. Далее процессы в системе будут в точности повторяться.

Таким образом, «медленные» движения рабочей точки на участках $d a$ и $b c$ периодически чередуются с «быстрыми» (скачкообразными) движениями на участках $a b$ и $c d$, порождая колебания $u_{s}(t)$ релаксационного типа. Следовательно, траектория движения $a \rightarrow b \rightarrow c \rightarrow d \rightarrow a$ является устойчивым циклом, свидетельствующим об установившемся автоколебательном режиме в рассматриваемой системе. Периодическое изменение $u_{s}(t)$ происходит в пределах от $u_{1}$ до $u_{2}$, т. е. в пределах заранее задаваемой зоны (а она при необходимости может быть сделана достаточно узкой).

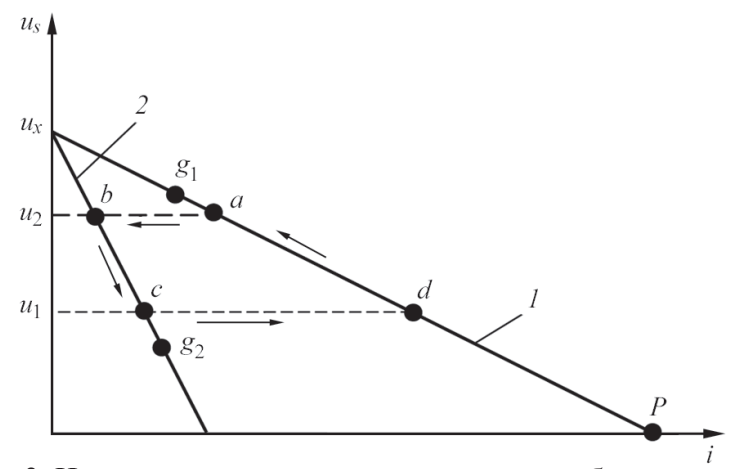

Рис. 3. Циклограмма установившегося автоколебательного режима: $1-u_{s}=u_{x}-S_{1} i ; 2-u_{s}=u_{x}-S_{2} i$ (обозначения см. в тексте) 


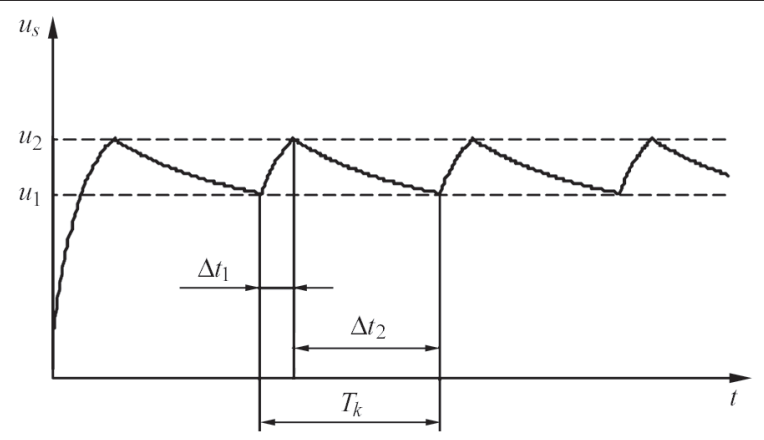

Рис. 4. График изменения напряжения $u_{s}(t)$ при заданных пороговых значениях $u_{1}$ и $u_{2}$ (описание см. в тексте)

Из рис. 4 видно, что «релаксационные» колебания напряжения $u_{s}(t)$ носят пилообразный характер. Период автоколебаний $T_{k}$ определяется суммой двух интервалов времени $\Delta t_{1}$ и $\Delta t_{2}$. Интервал $\Delta t_{1}$, в течение которого напряжение $u_{s}(t)$ возрастает от $u_{1}$ до $u_{2}$, определяется согласно уравнению (10) соотношением

$$
\Delta t_{1}=T_{1} \ln \left(\frac{u_{1}-g_{1}}{u_{2}-g_{1}}\right) .
$$

Аналогично, интервал времени $\Delta t_{2}$, в течение которого напряжение $u_{s}(t)$ убывает от $u_{2}$ до $u_{1}$, определяется в соответствии с уравнением (9) выражением

$$
\Delta t_{2}=T_{2} \ln \left(\frac{u_{2}-g_{2}}{u_{1}-g_{2}}\right) .
$$

Формулы (11) и (12) с учетом соотношений (7) приобретают следующий вид:
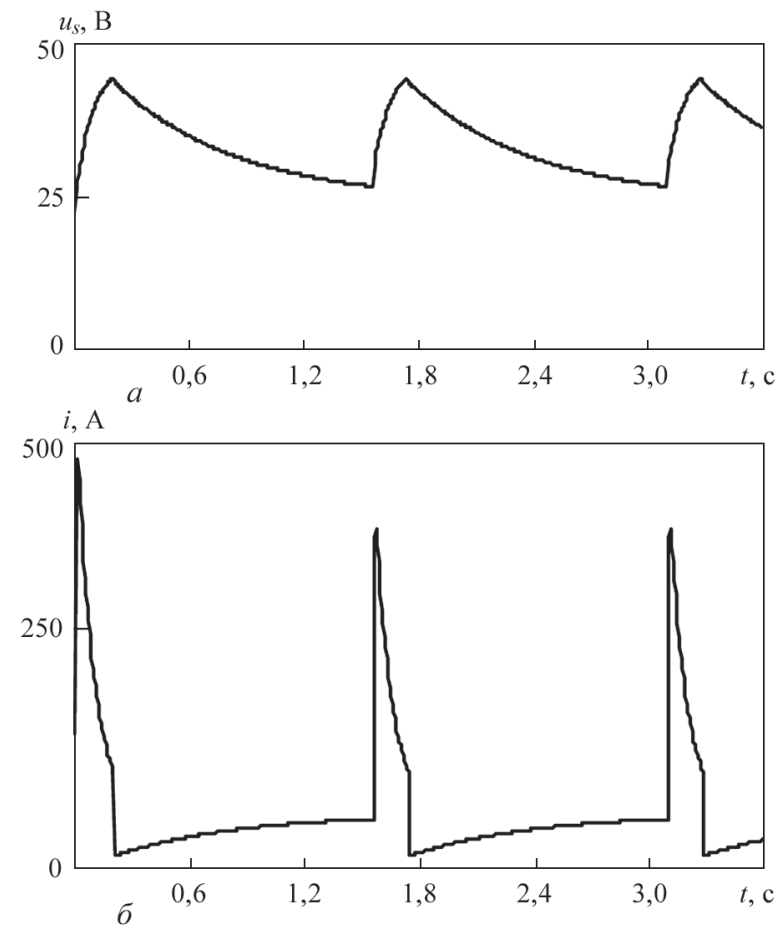

Рис. 5. Графики при $\xi=2,5 \mathrm{~B}: a-u_{s}(t) ; \sigma-i(t)$

$$
\Delta t_{1}=T_{1} \ln \left(\frac{\Delta g}{\xi}-1\right), \quad \Delta t_{2}=T_{2} \ln \left(\frac{\Delta g}{\xi}-1\right),
$$

где $\Delta g=g_{2}-g_{1}=\left(S_{2}-S_{1}\right) v_{e} M^{-1}$.

Следовательно,

$$
T_{k}=\left(T_{1}+T_{2}\right) \ln \left(\frac{\Delta g}{\xi}-1\right) .
$$

Период релаксации $T_{k}$ (при заранее выбранных значениях $S_{1}$ и $S_{2}$ ) зависит лишь от значения параметра $\xi$, варьируя которым можно устанавливать желаемую частоту $f=1 / T_{k}$ автоколебательного процесса рассматриваемой системы.

Результаты компьютерного моделирования. На рис. 5-7 представлены результаты моделирования автоколебательных процессов, устанавливающихся в рассматриваемой системе при следующих значениях параметров роботизированной дуговой сварки: $u_{x}=50 \mathrm{~B} ; u_{0}=18 \mathrm{~B} ; S_{1}=0,05 \mathrm{~B} / \mathrm{A} ; S_{2}=0,4 \mathrm{~B} / \mathrm{A}$; $S_{a}=0,02 \mathrm{~B} / \mathrm{A} ; R=0,01 \mathrm{Oм} ; L=5 \cdot 10^{-4} \Gamma \mathrm{H} ; E=2 \mathrm{~B} / \mathrm{Mm}$; $v_{e}=20 \mathrm{Mm} / \mathrm{c} ; M=0,31 \mathrm{~mm} /(\mathrm{A} \cdot \mathrm{c}) ; H=17 \mathrm{Mм}$.

Из рис. 5, в частности, видно, что напряжение на выходе источника питания дуги $u_{s}(t)$, как и следовало ожидать, имеет пилообразную форму,

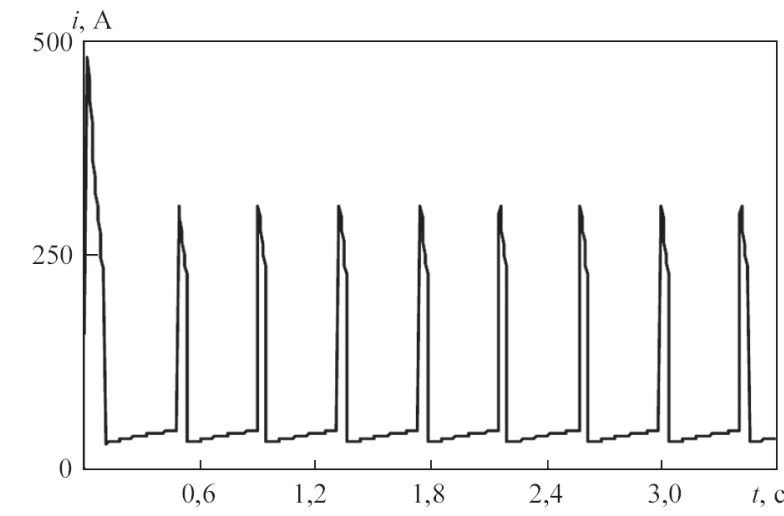

Рис. 6. График $i(t)$ при $\xi=8 \mathrm{~B}$

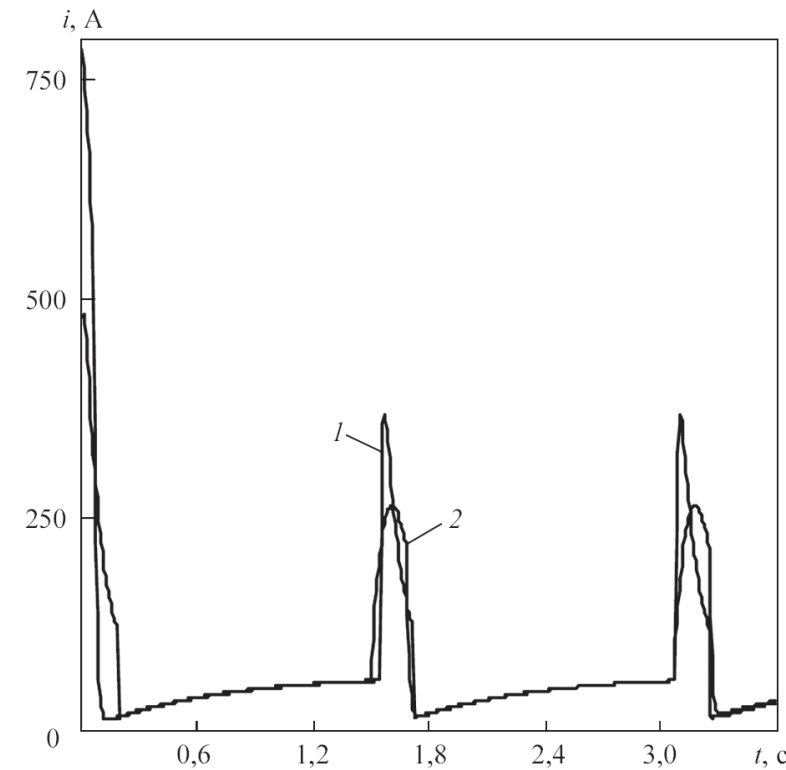

Рис. 7. Графики $i(t)$ при $\xi=2,5$ В: $1-L=5 \cdot 10^{-4} \Gamma \mathrm{H} ; 2-L=5 \cdot 10^{-3}$ 
а сварочный ток $i(t)$ носит импульсный характер. Импульсы тока возникают в моменты «мгновенного» перехода текущего состояния рассматриваемой системы из точки $c$ в точку $d$ (рис. 3 ).

График $i(t)$, изображенный на рис. 6 , получен при $\xi=8$ В. Сравнивая графики, представленные на рис. 5 и 6, видим, что при увеличении $\xi$ увеличивается частота следования импульсов тока $f=1 / T_{k}$.

Вернемся к вопросу о том, насколько существенно влияние на автоколебательный процесс неучтенного нами в (6) малого параметра $T_{L}$, зависящего согласно (4) от индуктивности системы $L$. Для выяснения этого вопроса, вместо упрощенного уравнения (6), при компьютерном моделировании использовалось исходное уравнение (3).

На рис. 7 представлены результаты моделирования, полученные при двух различных значениях индуктивности: $L=5 \cdot 10^{-4}$ Гн (кривая 1$)$ и $L=$ $=5 \cdot 10^{-3}$ Гн (кривая 2). Сравним сначала импульсы тока $i=i(t)$ на рис. 7 (кривая 1$)$ с импульсами тока на рис. 5 , полученными при $L=0$. Они практически не отличаются друг от друга ни по форме, ни по высоте. Следовательно, малые индуктивности (т. е. когда $L<5 \cdot 10^{-4}$ Гн) заметного влияния на динамику релаксационного процесса $i=i(t)$ не оказывают.

Сравним теперь кривые 1 и 2 на рис. 7 . Высота импульсов уменьшилась лишь в 1,5 раза при существенном (в 10 раз) увеличении индуктивности $L$. При этом несколько изменилась форма импульсов (сгладилась «вершина» импульса), но характер релаксационных колебаний практически остался без заметных изменений.

\section{Выводы}

1. Результаты теоретического рассмотрения и компьютерного моделирования позволяют сделать вывод о том, что вполне удовлетворительный режим импульсно-дуговой сварки плавящимся электродом может быть осуществлен, используя идеи теории систем с переменной структурой.

2. Особенность реализации рассматриваемого способа импульсно-дуговой сварки состоит в том, что коммутация вольт-амперных характеристик обеспечивается не принудительно, а автоматически на основе информацию о текущем состоянии процесса дуговой сварки.

3. Основным достоинством рассмотренного способа является простота, надежность и низкая стоимость его реализации.

\section{Список литературы}

1. Воропай Н.М., Илюшенко В.М., Ланкин Ю.Н. (1999) Особенности импульсно-дуговой сварки с синергетическим управлением параметрами режимов (Обзор). Автоматическая сварка, 6, 26-32.

2. Жерносеков А.М., Андреев В.В. (2007) Импульсная дуговая сварка плавящимся электродом (обзор). Там же, 10, 48-52.

3. Крампит Н.Ю., Буракова Е.М., Крампит М.А. (2014) Краткий обзор способов управления процессом дуговой сварки в среде защитных газов. Современные проблемы науки и образования, 1. URL: http://www.scienceeducation.ru/115-12069.

4. Дюргеров Н.Г., Ленивкин В.А. (2015) Технологическая стабильность импульсно-дуговой сварки плавящимся электродом. Сварочное производство, 4, 14-18.

5. Шейко П.П., Павшук В.М. (1992) Источник питания для импульсно-дуговой сварки плавящимся электродом с плавным регулированием параметров. Автоматическая сварка, 6, 44-46.

6. Jing Nie, Xiao-Feng Meng, Yu Shi. (2011) Study on Evaluation Method of Aluminum Alloy Pulse MIG Welding Stability Based on Arc Voltage Probability Density. Signal and Information Processing, 2, 159-164.

7. Mathivanan A., Senthilkumar A., Devakumaran K. (2015) Pulsed current and dual pulse gas metal arc welding of grade AISI. Defense Technology, 11(3), 269-274.

8. Волик Б.Г. (ред.) (1988) Теория управления. Терминология. Bыл. 107. Москва, Наука.

9. Цыбулькин Г.А. (2014) Адаптивное управление в дуговой сварке. Киев, Сталь.

\section{References}

1. Voropaj, N.M., Ilyushenko, V.M., Lankin, Yu.N. (1999) Peculiarities of pulsed-arc welding with synergic control of mode parameters (Review). Avtomatich. Svarka, 6, 26-32 [in Russian].

2. Zhernosekov, A.M., Andreev, V.V. (2007) Pulsed metal arc welding (Review). The Paton Welding J., 10, 40-43.

3. Krampit, N.Yu., Burakova, E.M., Krampit, M.A. (2014) Short review of methods for control of shielded-gas arc welding process. In: Modern problems of science and education, 1. URL:http://www.science-education.ru/11512069 [in Russian].

4. Dyurgerov, N.G., Lenivkin, V.A. (2015) Technological stability of consumable electrode pulsed-arc welding. Svarochn. Proizvodstvo, 4, 14-18 [in Russian].

5. Shejko, P.P., Pavshuk, V.M. (1992) Power source for consumable electrode pulsed-arc welding with smooth control of parameters. Avtomatich. Svarka, 6, 44-46 [in Russian].

6. Jing Nie, Xiao-Feng Meng, Yu Shi (2011) Study on evaluation method of aluminum alloy pulse MIG welding stability based on arc voltage probability density. Signal and Information Processing, 2, 159-164.

7. Mathivanan, A., Senthilkumar, A., Devakumaran, K. (2015) Pulsed current and dual pulse gas metal arc welding of grade AISI. Defense Technology, 11(3), 269-274.

8. (1988) Control theory. Terminology. Issue 107. Moscow, Nauka [in Russian].

9. Tsybulkin, G.A. (2014) Adaptive control in arc welding. Kiev, Stal [in Russian]. 


\title{
ДОСЛІДЖЕННЯ ІМПУЛЬСНО-ДУГОВИХ ПРОЦЕСІВ ПРИ ПЕРІОДИЧНІЙ ЗМІНІ ВОЛЬТ-АМПЕРНИХ ХАРАКТЕРИСТИК ДЖЕРЕЛА ЖИВЛЕННЯ ДУГИ
}

\author{
Г.О. Цибулькін
}

IE3 ім. Є.О. Патона НАН України. 03150, г. Киев, ул. Казимира Малевича, 11. E-mail: office@paton.kiev.ua Розглянуто імпульсно-дугові процеси, які здійснюються шляхом періодичного перемикання вольтамперних характеристик джерела живлення дуги, що мають різну кривизну. При цьому сама комутація зазначених характеристик здійснюється не примусово, а автоматично на основі інформації про поточний стан системи «джерело живлення-дуга». Основна мета - з'ясувати наскільки ефективний зазначений спосіб імпульсно-дугового зварювання плавким електродом в середовищі захисного газу. У статті наводяться результати теоретичних досліджень і комп'ютерного моделювання автоколивальних процесів, що протікають в даній системі. Виведено формулу для попередньої оцінки частоти проходження імпульсів зварювального струму. Варіюючи значенням визначеного параметра, що фігурує в цій формулі, можна задавати бажану частоту проходження вказаних імпульсів. Бібліогр. 9, рис. 7.

Ключові слова: імпульсно-дугове зварювання, плавкий електрод, комутаиіл вольт-амперних характеристик, комп'ютерне моделювання, частота проходження імпульсів зварювального струму

\section{STUDY OF PULSED ARC PROCESSES, GENERATED BY PERIODIC SWITCHING OF VOLT-AMPERE CHARACTERISTICS OF THE ARC POWER SOURCE}

\author{
G.A. Tsybulkin
}

E.O. Paton Electric Welding Institute of the NAS of Ukraine. 11 Kazimir Malevich Str., 03150, Kyiv, Ukraine.

E-mail:office@paton.kiev.ua

The article discusses the pulsed arc processes carried out by periodic switching of the volt-ampere characteristics of the arc power source having different steepness. At the same time, the commutation of the mentioned characteristics itself is realized not forcibly, but automatically based on the information about the current state of the system "power source-arc". The main aim is to find out how effective is this method of pulsed arc welding with consumable electrode in a shielding gas environment. The article presents the results of theoretical investigations and computer simulation of self-oscillatory processes, occurring in the system under consideration. A formula was derived for a preliminary evaluation of the pulse repetition rate of the welding current. By varying the value of a certain parameter appearing in this formula, it is possible to set the desired repetition rate of the indicated pulses. 9 Ref., 7 Fig.

Keywords: pulsed arc welding, melting electrode, switching of volt-ampere characteristics, computer simulation, pulse repetition rate of welding current

Всеукраїнська конференція

\section{ПРОБЛЕМИ ЗВАРЮВАННЯ ТА СПОРІДНЕНИХ ТЕХНОЛОГІЙ}

Присвячується 60-річчю кафредрі зварювального виробництва НУК

$$
\text { 17-19 вересня } 2019 \text { р. Миколаїв, Коблеве }
$$

\section{Тематичні напрямки роботи конференції:}

- Технології, матеріали та устаткування зварювання плавленням

- Зварювання у твердому стані

- Паяння та споріднені процеси

- Інженерія поверхні
- Нові конструкційні матеріали та покриття

- Міцність зварних та спаяних з'єднань

- Комп'ютерне моделювання та експериментальні дослідження напружено-деформованого стану зварних і спаяних з'єднань

\section{Оргкомітет:}

Національний університет кораблебудування ім. адмірала Макарова

Вчений секретар оргкомітету - Костін Олександр Михайлович тел. +38(050) 982-97-67; E-mail: koctin.weld@gmail.com 


\title{
ВЛИЯНИЕ ФОРМЫ ИНСТРУМЕНТА ДЛЯ СВАРКИ ТРЕНИЕМ С ПЕРЕМЕШИВАНИЕМ НА ФИЗИКО-МЕХАНИЧЕСКИЕ СВОЙСТВА СВАРНЫХ СОЕДИНЕНИЙ АЛЮМИНИЕВОГО СПЛАВА ЕN AW 6082-Т6
}

\author{
К. Красновский ${ }^{1}$, Ю.А. Хохлова ${ }^{2}$, М.А. Хохлов ${ }^{2}$ \\ ${ }^{1}$ Институт сварки. 44-100, Польша, Гливице, ул. Бл. Чеслава, 16-18. E-mail: is@is.gliwice.pl \\ ${ }^{2}$ ИЭС им. Е.О. Патона НАН Украины. 03150, г. Киев, ул. Казимира Малевича, 11. \\ E-mail: office@paton.kiev.ua
}

\begin{abstract}
В статье представлены результаты исследования формирования макроструктуры и распределения механических свойств в сварных соединениях плоских образцов из алюминиевого сплава EN AW 6082-T6 толщиной 8 мм, полученных методом сварки трением с перемешиванием с применением трех типов специально разработанных пинов с заплечиками: $\mathrm{C}$ - цилиндрического резьбового пина и заплечика со спиральной канавкой; Т — цилиндрического резьбового пина с тремя канавками и заплечика со спиральной канавкой; $\mathrm{S}$ - гладкого цилиндрического пина без резьбы и плоского заплечика. Сварка трением с перемешиванием проводилась на оборудовании Института сварки в Гливице (Польша), а обработку образцов и механические испытания проводили в ИЭС им. Е.О. Патона НАН Украины. Для механических испытаний индентированием использовали прибор «Микрон-гамма», позволяющий по предельным значениям соотношения твердости к модулю упругости Юнга экспериментально идентифицировать структурное состояние металла после измельчения и определить наличие деформационного упрочнения. Установлено, что для всех трех образцов твердость зоны термического влияния понижается, а в зоне термомеханического влияния твердость повышается. Максимальные значения твердости свойственны центральной части ядра сварных соединений, а также светлым овальным концентричным фрагментам структуры верхней и нижней части ядра. По наличию в ядре наноразмерной упрочненной структуры и равномерности ее распределения, а также хорошей рассеянности оксидных пленок и отсутствию несплошностей, оптимальным можно считать сварку трением с перемешиванием инструментом С-типа. Сделано предположение, что формирование равномерной структуры в сварных швах можно получать при трех-четырех оборотах сварки трением с перемешиванием инструмента на одном месте. Библиогр. 21, табл. 1, рис. 7.
\end{abstract}

Ключевые слова: сварка трением с перемешиванием, зона термомеханического влияния, ядро сварного шва, индентирование, индентор Берковича, модуль Юнга, физико-механические свойства

Технология сварки трением с перемешиванием (СТП) применяется для соединения различных сплавов магния, меди, титана, цинка и даже стали, но основное промышленное применение СТП для стыкового соединения длинномерных деталей из алюминиевых сплавов (около 99 \% всех соединений). Характеристики технологии СТП и ее преимущества, связанные с конкретным типом соединений или применением, являются предметом многочисленных публикаций [1-11]. В общем случае, при СТП вращающийся инструмент, оборудованный пином и заплечиком, медленно погружается между краями соединяемых элементов (касаясь друг друга) и перемещается вдоль линии сварки [5]. Тепло, необходимое для пластификации материала, генерируется трением между инструментом и соединяемыми материалами, вращательное и поступательное движение пина обеспечивает интенсивную пластическую деформацию нагретого размягченного материала перемещаться от кончика пина к плечу, создавая

( С К. Красновский, Ю.А. Хохлова, М.А. Хохлов, 2019 непрерывную структуру соединения с обеих сторон соединяемых материалов.

Основные технологические параметры процесса СТП: скорость вращения инструмента и направление вращения, об/мин; линейная скорость сварки, мм/мин; угол наклона инструмента относительно поверхности свариваемых элементов, град.; тип инструмента и его размеры - диаметр пина и диаметр заплечика, мм [10].

Ключевым параметром, определяющим стандарт качества СТП соединений, является геометрия пина для перемешивания, которая обусловливает различные условия локального нагрева и взаимного массопереноса металла соединяемых элементов. Помимо пина, важным элементом СТП инструмента является заплечик, основной функцией которого является выделение тепла за счет трения между заплечиком и свариваемыми материалами, передача давления и образование деформаций в области поверхности сварного шва.

Считается, что после интенсивной скручивающей пластической деформации в ядре СТП шва 


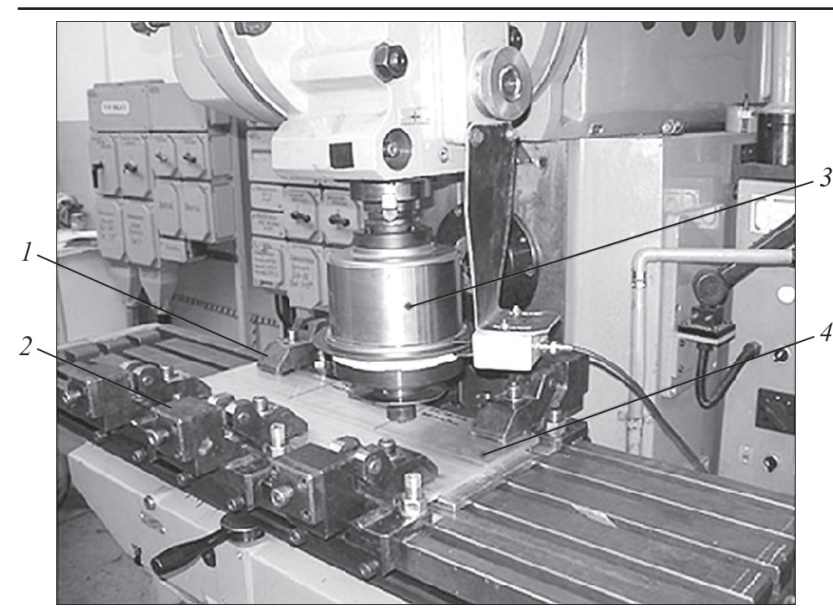

Рис. 1. Вид установки для сварки трением с перемешиванием: 1 - инструмент; 2 - крепеж; 3 - блок крепления инструмента; 4 - свариваемые части

происходит изменение характера межатомных взаимодействий и формирование близкой к наноразмерной структуры. Наряду с формированием наноструктуры, может происходить формирование метастабильных состояний, пересыщенных твердых растворов и метастабильных фаз. Также, за счет больших деформаций материала обеих кромок свариваемых деталей, термомеханическая зона может содержать сильно фрагментированную и разориентированную структуру рекристаллизованного аморфного состояния. Все это неизбежно сказывается на физических и химических свойствах зоны соединения. Поэтому представляет интерес исследование зависимости влияния ключевого параметра СТП — геометрии сварочного инструмента на формирование нанодисперсных зон сварных швов с минимальной дефектностью и равномерной структурой, что должно положительно влиять на прочность сварного соединения в целом.

Целью данной работы является определение оптимальной формы СТП инструмента по результатам локального исследования структуры и физико-механических свойств зоны термомеханического влияния в сварных швах, выполненных с применением трех типов специально разработанных пинов с заплечиками. Для решения поставленной цели было проведено совместное исследование - СТП проводилась на оборудовании Института сварки в Гливице, а обработку образцов и механические испытания проводили в ИЭС им. Е.О. Патона НАН Украины. По результатам механических испытаний и соотношению твердости к модулю упругости Юнга, экспериментально идентифицировали структурное состояние зон сварных швов.

Оборудование, материалы и методы исследования. СТП проводилась на модифицированной фрезерной установке FYF32JU, оснащенной системой захвата и измерительной головкой контроля параметров процесса сварки (рис. 1).

Для сварки были выбраны образцы алюминиевого сплава 6082-Т6 (аналог АД35) в виде плоских горячекатаных прутков длиной 10 см и толщиной 0,8 см. Термическая обработка сплава проведена при температуре около $540^{\circ} \mathrm{C}$, с последующим искусственным старением при $170{ }^{\circ} \mathrm{C}$. Химический состав представлен в таблице.

Инструменты СТП трех типов (рис. 2) были специально изготовлены из быстрорежущей высокопрочной (на кручение) легированной стали HS6-5-2 повышенной износостойкости до $600{ }^{\circ} \mathrm{C}$. По типу геометрических особенностей они классифицированы следующим образом:

- C - обычный инструмент «conventional» типа, состоящий из корпуса, цилиндрического резьбового пина и заплечика со спиральной канавкой;

- Т - инструмент типа «triflute», состоящий из корпуса, цилиндрического резьбового пина с тремя канавками и заплечика со спиральной канавкой;

- S - простой «simple» инструмент, состоящий из корпуса, гладкого цилиндрического пина без резьбы и плоского заплечика.

Химический состав алюминиевого сплава 6082, мас. \% [12]

\begin{tabular}{|c|c|c|c|c|c|c|c|c|c|}
\hline Сплав & $\mathrm{Si}$ & $\mathrm{Fe}$ & $\mathrm{Cu}$ & $\mathrm{Mn}$ & $\mathrm{Mg}$ & $\mathrm{Cr}$ & $\mathrm{Zn}$ & $\mathrm{Ti}$ & $\mathrm{Al}$ \\
\hline 6082 & $0,7 \ldots 1,3$ & до 0,5 & 0,1 & $0,4 \ldots 1,0$ & $0,6 \ldots 1,2$ & до 0,25 & до 0,2 & до 0,1 & Остальное \\
\hline
\end{tabular}

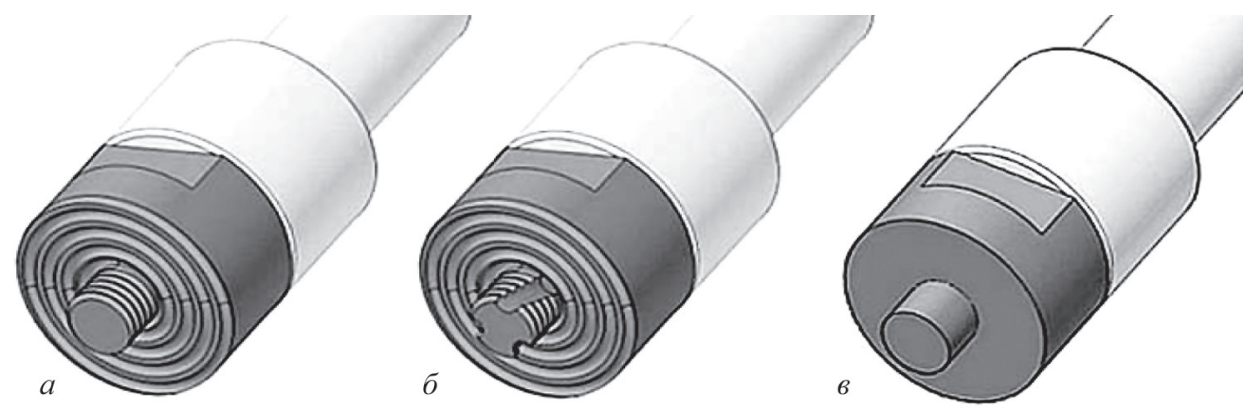

Рис. 2. Инструменты для сварки трением с перемешиванием: $a-$ тип $\mathrm{C} ; \sigma-\mathrm{T} ; 6-\mathrm{S}$ 


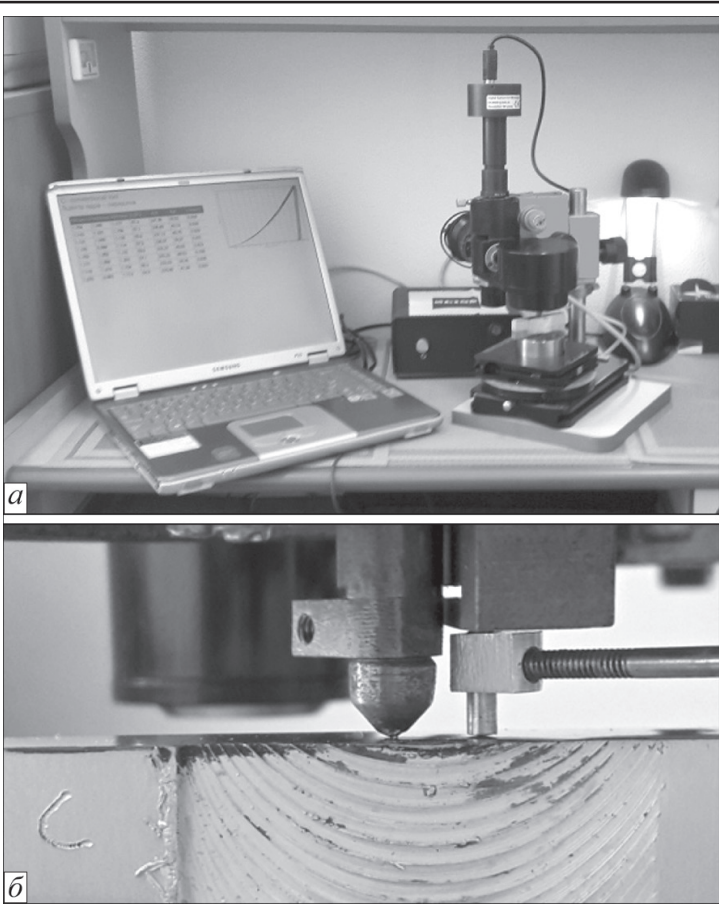

Рис. 3. Прибор «Микрон-гамма» (a) в процессе записи диаграммы непрерывного вдавливания индентора в материал (б)

Процесс СТП проводили в режиме: скорость вращения инструмента -710 об/мин; линейная скорость сварки - 900 мм/мин; инструменты типа $\mathrm{C}, \mathrm{T}$ и $\mathrm{S}$ с длиной пина 7,8 мм; угол наклона инструмента по отношению к сварным заготовкам $-1,5^{\circ}$, направление вращения инструмента - по часовой стрелке. Указанные параметры обеспечили наиболее экономичный процесс с точки зрения скорости сварки. После сварки каждый шов проходил визуальную проверку соответствия стандарту с положительным результатом.

Для оптического исследования макроструктуры СТП соединений были приготовлены шлифы по стандартной для алюминиевых сплавов методике - поверхности образцов шлифовали на станке 3Е88ИМ наждачной бумагой разной зернистости (Р120 - 100...125 мкм, Р240 - 50..63 Р $600-20 \ldots 28$, P1200 - 10...14), полировали пастой ГОИ до зеркального блеска, промывали водой и спиртом, просушивали фильтровальной бумагой. Травление структуры проводили реактивом 5 мл $\mathrm{HNO}_{3}, 30$ мл $\mathrm{CH}_{3} \mathrm{COOH}, 300$ мл $\mathrm{H}_{2} \mathrm{O}$.

Для механических испытаний индентированием использовали прибор «Микро-гамма» (рис. 3, $a)$, разработанный в лаборатории нанотехнологий аэрокосмического института Национального авиационного университета Украины. Индентирование - тест, основанный на методе Оливера и Фарра [13-16] для определения твердости $H$ и модуля упругости $E$ по диаграммам индентирования, которые фиксируются при непрерывном вдавливании алмазного трехгранного пирамидального индентора Берковича $[17,18]$ в соответ- ствии с ISO/FDIS 14577-1: 2015; Metallic materials - Instrumented indentation test for hardness and materials parameters - Part 1: Test method (ISO Central Secretariat, Geneva, Switzerland). Индентирование проводили на шлифованной поверхности образцов без травления при нагружении индентоpa 100 г (рис. 3, б).

По соотношению $H / E$ экспериментально идентифицировали структурное состояние металла после измельчения и определяли наличие деформационного упрочнения. Известно, что все материалы в различном структурном состоянии, в зависимости от величины отношения твердости к модулю упругости $(H / E)$ можно разместить в ряд, включающий три группы [19-21]. Первая группа - крупнокристаллические $(H / E<0,04)$, вторая - мелкокристаллические и наноматериалы $(H / E \approx 0,05 \ldots 0,09)$ и третья группа - материалы в аморфном и аморфно-кристаллическом состояниях $(H / E \geq 0,1)$. Установление предельных значений величины $H / E$ для различных структурных состояний облегчает идентификацию материала с неизвестным структурным состоянием.

Результаты и обсуждение. Наблюдаемые в сварных швах СТП (рис. 4) несимметричные стороны «набегания» (AS) и «отхода» (RS), обусловлены несимметричностью скручивающей деформации металла и связаны с несимметричностью нахождения начальной точки касания инструмента при растущем давлении, а следовательно, и с различием распределения температурных полей нагрева при интенсивном механическом воздействии.

Типичным для всех трех образцов СТП является образование зоны ядра в центре соединений, которое содержит овальные концентричные фрагменты, различающиеся структурой. Образование овальных колец связано с особенностями перемешивания металла различными наконечниками инструмента. К ядру примыкает сложный профиль, который образует верхнюю часть шва. В результате травления шлифов выделились дефекты соединений в виде локальных несплошностей

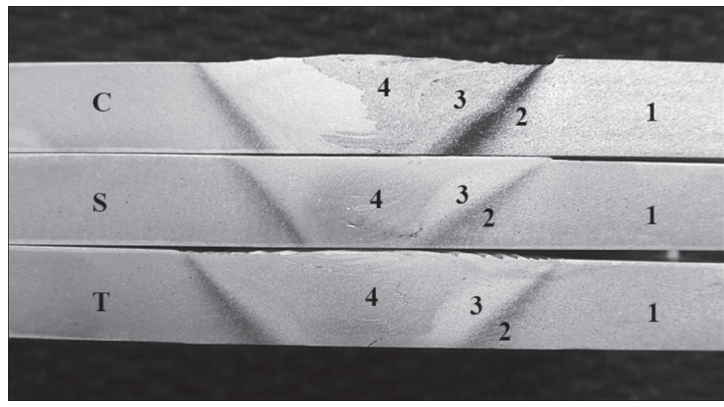

Рис. 4. Макроструктура и зоны СТП соединений алюминиевого сплава EN AW 6082-Т6 толщиной 0,8 см (1-4 - описание см. в тексте) 


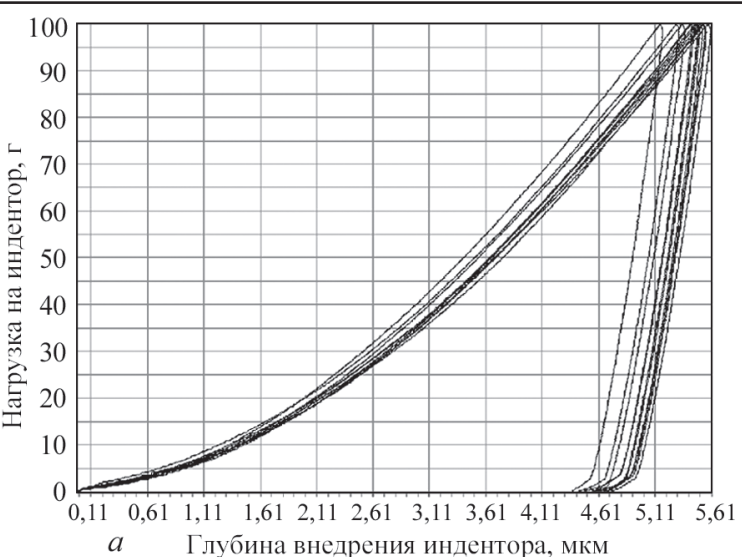

Рис. 5. Различие диаграмм индентирования основного металла и полостей по линии, отделяющей центр ядра от окружающей его зоны термомеханического влияния. Эти полосы оксида алюминия присущи поверхностям свариваемых материалов, потому что не были достаточно механически распределены сварочным инструментом. Подобный тип дефекта типичен для швов СТП и зависит от линейной скорости сварки, т. е. при увеличении линейной скорости сварки рассеивание оксидов при механическом массопереносе увеличивается и дефектность снижается.

Еще один типичный горизонтальный дефект, вызванный недостаточным перемешиванием материалов, наблюдается в образце, полученном с применением гладкого инструмента S-типа, без
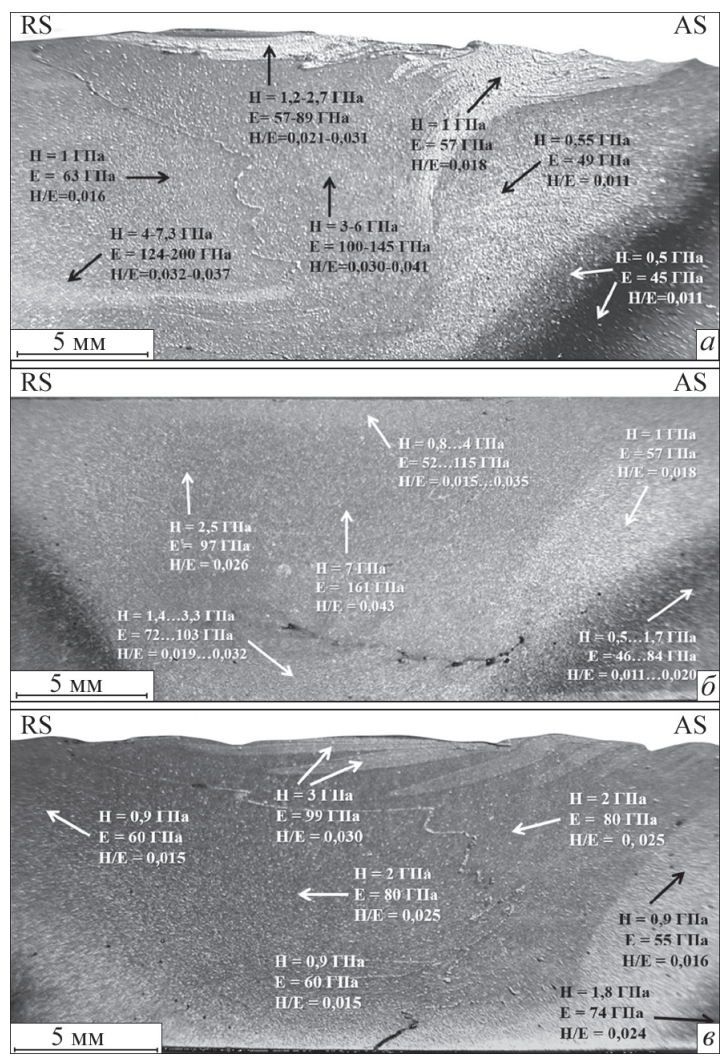

Рис. 6. Распределение твердости $H$, модуля упругости $E$ и сопротивляемости деформации $H / E$ в микроструктуре СТП шва $\mathrm{C}$-типа инструмента $(a)$; S-типа (б); Т-типа ( $)$

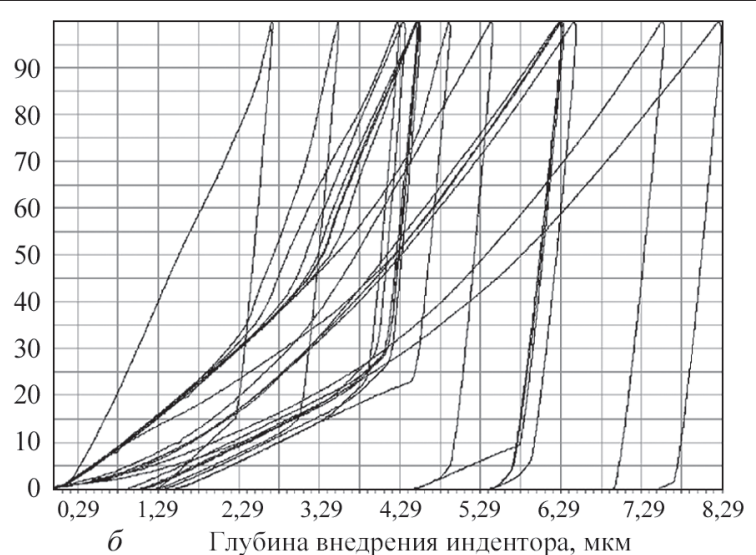

(a) и различных зон термического влияния образца S-типа (б)

резьбы на цапфе инструмента. Причиной такого дефекта является то, что плоские поверхности инструмента при трении приводят к локальному перегреву металла до температуры плавления.

Таким образом, в сварном соединении сформированы четыре характерные для СТП зоны: непосредственно к зоне 1 (основной металл - ОМ) примыкает зона 2, где металл заготовок остается недеформированным и изменяет свою структуру только под воздействием нагрева (зона термического влияния - 3ТВ); зона 3, где металл подвергается значительным пластическим деформациям и нагреву (зона термомеханического влияния 3ТМВ) и зона 4 - это ядро соединения, где происходит динамическая рекристаллизация.

Механический тест показал принципиальное, для швов СТП, отличие диаграмм индентирования основного металла (рис. $5, a$ ) и различных зон (рис. 5,6 ), что характеризует присутствие измененного структурного состояния.

Для всех трех образцов твердость зоны 2 (ЗТВ) понижается. Максимальные значения твердости свойственны зоне 4 - центральной части ядра (рис. 6), а также светлым овальным концентричным фрагментам структуры верхней и нижней части ядра (рис. $6, a, в$ ). Усредненные значения физико-механических свойств зонам СТП соединений трех типов следующие:

$$
\begin{aligned}
& \text { зона } 1(\mathrm{OM})-H=1,2 \text { ГПа, } E=70 \text { ГПа; } \\
& \text { зона } 2 \text { (ЗТВ) }-H=0,5 \ldots 1,0 \text { ГПа, } \\
& E=45 \ldots 57 \text { ГПа; } \\
& \text { зона } 3 \text { (ЗТМВ) }-H=1,0 \ldots 3,0 \text { ГПа, } \\
& E=63 \ldots 103 \text { ГПа; } \\
& \text { зона } 4 \text { (ядро) }-H=2,0 \ldots 7,0 \text { ГПа, } \\
& E=80 \ldots 161 \text { ГПа. }
\end{aligned}
$$

На рис. 6, б показано сварное соединение, полученное инструментом С-типа с цилиндрическим резьбовым пином и заплечиком со спиральной канавкой, в котором зафиксировано максимальное, для всех трех исследуемых образцов, значение твердости - 7,3 ГПа (светлый овальный 

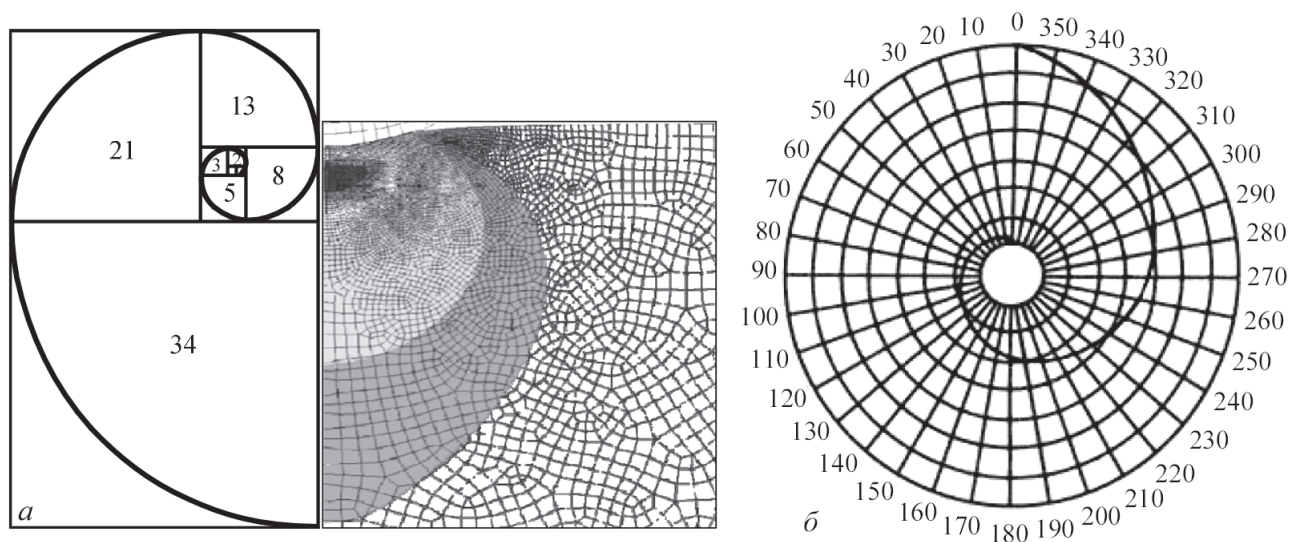

Рис. 7. Спираль Фибоначчи и модель СТП с масштабным изменением фрагментов структуры (a) и радианное изменение сегментов структуры при скручивании (б)

фрагмент нижней части ядра), также максимальные значения $E$ до 200 ГПа и соотношение $H / E$ до 0,041 . Такие значения фиксируют присутствие нанодисперсной многофазной структуры, сформировавшейся при максимально высокой степени деформации. Подобная структура свойственна также 4-ой зоне ядра СТП швов: С-типа $-H / E$ до 0,041 ; S-типа $-H / E$ до 0,043 при исходном поликристаллическом структурном состоянии основного металла $H / E=0,017$. Подобное упрочнение при измельчении зерен структуры обычно связывают с уменьшением плотности дислокаций и их торможением.

Таким образом, если считать преимуществом наличие в шве, выполненном СТП, наноразмерной упрочненной структуры и равномерность ее распределения, хорошую рассеянность оксидных пленок и отсутствие несплошностей, то оптимальным в данном исследовании является инструмент С-типа.

В процессе работы было сделано предположение, что, по степени измельчения до наноразмерности зерен структуры металла при скручивающей деформации, можно определить количество оборотов инструмента для СТП на одном месте. Если скручивающую деформацию рассматривать в виде спиральной математической пропорции Фибоначчи $-1,2,3,5,8,13 \ldots$ (рис. $7, a$ ), где полный оборот (раскручивание) - это последовательность из четырех значений, то в обратном направлении (скручивание) спирали существенное измельчение структуры получится уже после деформации на пол-оборота $0 \ldots 180^{\circ}$ (рис. 7, б), а для создания однородной наноструктуры требуется деформация в несколько оборотов.

Приняв усредненным диаметром зерна измельченной структуры - 100 нм, а средним диаметром зерна исходного поликристаллического алюминия -100000 нм (0,1 мм), это соотношение составит 1:1000. Тогда, измельчение зерна в такой обратной пропорции произойдет при трех-четыpех оборотах СТП инструмента на одном месте:

1-й оборот - 1597, 987, 610, 377;

2-й оборот - 233, 144, 89, 55;

3-й оборот - 34, 21, 13, 8;

4-й оборот $-5,3,2,1$.

Технологически этим можно управлять, меняя скорость оборотов и/или линейную скорость перемещения инструмента при сварке, но обычно сварочное оборудование имеет фиксированную скорость, что ограничивает контроль.

\section{Заключение}

Исследованы физико-механические свойства сварных швов соединений из алюминиевого сплава EN AW 6082-T6, полученных сваркой трением c перемешиванием с использованием трех инструментов различной геометрической формы. Для всех трех образцов твердость зоны термического влияния понижается, а в зоне термомеханического влияния твердость повышается. Максимальные значения твердости свойственны центральной части ядра сварных соединений, а также светлым овальным концентричным фрагментам структуры верхней и нижней части ядра. По наличию в ядре сварных швов наноразмерной упрочненной структуры и равномерности ее распределения, а также хорошей рассеянности оксидных пленок и отсутствию несплошностей, оптимальным является СТП инструмент С-типа. Сделано предположение, что формирование равномерной структуры в сварных швах можно получать при трех-четырех оборотах инструмента для СТП на одном месте.

\section{Список литературы/References}

1. Thomas W.M., Nicholas E.D., Needham J.C. et al. (1991) Friction stir butt welding. European Patent Specification 06 $15480 \mathrm{~B} 1$.

2. Dawes C.J. (1995) An introduction of friction stir welding and its development. Welding \& Metal Fabrication, 63, 1316.

3. Mishra R.S., Ma Z.Y. (2005) Friction Stir Welding and Processing. Mater. Sci. Eng., 50A, 1-78. 
4. Uday M.B., Ahmad Fauzi M.N., Zuhailawati H., Ismail A.B. (2010) Advances in Friction Welding Process: A Review. Sci. Technol. Weld. Join., 15, 534-558.

5. Krasnowski K., Sędek P., Łomozik M., Pietras A. (2011) Impact of selected FSW parameters on mechanical properties of 6082-T6 aluminium alloy butt joints. Archives of Metallurgy and Materials, 56, 4, 965-973.

6. Threagill P.L., Leonard A.J., Shercliff H.R., Withers P.J. (2009) Friction Stir Welding of Aluminium Alloys. Int. Mater. Rev., 54, 2, 49-93.

7. Nandan R., DebRoy T., Bhadeshia H.K.D.H. (2008) Recent Advances in Friction-Stir Welding: Process, Weldment Structure and Properties. Prog. Mater Sci., 53, 980-1023.

8. Krasnowski K., Dymek S. (2013) A comparative analysis of the impact of tool design to fatigue behavior of single-sided and double-sided welded butt joints of EN AW 6082-T6 Alloy. Journal of Materials Engineering and Performance, 22, 12, 3818-3824.

9. Krasnowski K. (2014) Fatigue and static properties of friction stir welded aluminium alloy 6082 lap joints using Triflute-type and smooth tool. Archives of Metallurgy and Materials, 59, 1, 157-162.

10. Kalemba I., Kopyscianski M., Dymek S. (2010) Investigation of Friction Stir Welded Al-Zn-Mg-Cu Aluminum Alloys. Steel Research International, 81, 9, 1088-1096.

11. Mustafa B., Adem K. (2004) The influence of stirrer geometry on bonding and mechanical properties in friction stir welding process. Materials and Design, 25, 343-347.

12. Standard DIN EN 573-3:2009, Aluminium and aluminium alloys. Pt 3: Chemical composition and form of wrought products. Chemical composition and form of products.

13. Oliver W.C., Pharr G.M. (1992) An improved technique for determining the hardness and elastic modulus using load displacement sensing indentation experiments. J. Mater. Res., 7, 1564-1583

14. Oliver W.C., Pharr G.M. (2004) Measurement of hardness and elastic modulus by instrumented indentation: Advances in understanding and refinements to methodology. Ibid, 19, 1, 3-21.

15. Хохлова Ю.А., Клочков И.Н., Гринюк А.А., Хохлов М.А. (2009) Верификация значений модуля упругости Юнга, получаемых микропиновой системой Микрон-гамма. Техническая диагностика и неразрушающий контроль, 1, 30-32.

Khokhlova, Yu.A., Klochkov, I.N., Grinyuk, A.A., Khokhlov, M.A. (2009) Verification of Young's modulus determination using «Mikron-gamma» microprobe system. Tekh. Diagnost. i Nerazrush. Kontrol, 1, 30-32 [in Russian].

16. Хохлова Ю.А., Ищенко Д.А., Хохлов М.А. (2017) Индентирование от микро- до нанометрового уровня и примеры исследования свойств материалов с особой структурой. Там же, 1, 30-36

Khokhlova, Yu.A., Ishchenko, D.A., Khokhlov, M.A. (2017) Indentation from macro- to nanometer level and examples of investigation of properties of materials with a special structure. Ibid., 1, 30-36 [in Russian].

17. Nano indenters from micro star technologies. Revision 2.3. http://www.microstartech.com

18. Kazuhisa Miyoshi (2002) Surface Characterization Techniques: An Overview NASA/TM-2002-211497, 12-22.

19. Doener M.F., Nix W.D. (1986) Indentation problems. J. Mater. Res., 1, 601-614.

20. Горбань В.Ф., Мамека Н.А., Печковский Э.П., Фирстов С.А. (2007) Идентификация структурного состояния материалов методом автоматического индентирования. Сб. докладов Харьковской нанотехнологической ассамблеи 23-27 апреля 2007 г., Харьков. Наноструктурные материалы. Неклюдов И.М., Шпак А.П., Шулаев В.М. (ред.), Т. 1. сc. 52-55.

Gorban, V.F., Mameka, N.A., Pechkovsky, E.P., Firstov, S.A. (2007) Indentation of structural state of materials by automatic indentation method. In: Proc. of Kharkov Nanotechnological Assembly (Ukraine, Kharkov, 23-27 April 2007). Ed. by I.M. Neklyudov et al. V.1. Nanostructural materials, 52-55 [in Russian].

21. Фирстов С.А., Горбань В.Ф., Печковский Э.П., Мамека Н.А. (2007) Связь прочностных характеристик материалов с показателями автоматического индентирования. Материаловедение, 11, 26-31.

Firstov, S.A., Gorban, V.F., Pechkovsky, E.P., Mameka, N.A. (2007) Relationship of strength characteristic with indexes of automatic indentation. Materialovedenie, 11, 26-31 [in Russian].

\title{
ВПЛИВ ФОРМИ ІНСТРУМЕНТУ ДЛЯ ЗВАРЮВАННЯ ТЕРТЯМ 3 ПЕРЕМІШУВАННЯМ НА ФІЗИКО-МЕХАНІЧНІ ВЛАСТИВОСТІ ЗВАРНИХ 3’СДНАНЬ АЛЮМІНІСВОГО СПЛАВУ ЕN АW 6082-Т6
}

\author{
К. Красновський ${ }^{1}$ Ю.А. Хохлова ${ }^{2}$, М.А. Хохлов ${ }^{2}$
}

${ }^{1}$ Інститут зварювання. 44-100, Польща, Глівице, вул. Бл. Чеслава, 16-18. E-mail: is@is.gliwice.pl

${ }^{2}$ IE3 ім. Є.О. Патона НАН України. 03150, м. Київ, вул. Казимира Малевича, 11. E-mail: office@paton.kiev.ua

У статті представлено результати дослідження формування макроструктури та розподілу механічних властивостей в зварних з'єднаннях плоских зразків з алюмінієвого сплаву EN AW 6082-Т6 товщиною 8 мм, отриманих методом зварювання тертям 3 перемішуванням із застосуванням трьох типів спеціально розроблених пинів із заплечиками: С — циліндричного пина і заплечика зі спіральною канавкою; T — циліндричного пина з трьома канавками і заплечика зі спіральною канавкою; S - гладкого циліндричного пина без різьблення і плоского заплечика. Зварювання тертям з перемішуванням проводилось на обладнанні Інституту зварювання в Глівице (Польща), а обробку зразків і механічні випробування проводили в IE3 ім. Є.О. Патона НАН України. Для механічних випробувань індентуванням використовували прилад «Мікрон-гамма», що дозволяє по граничних значеннях співвідношення твердості до модуля пружності Юнга, експериментально ідентифікувати структурний стан металу та визначити наявність деформаційного зміцнення. Встановлено, що для всіх трьох зразків твердість зони термічного впливу знижується, а в зоні термомеханічного впливу твердість підвищується. Максимальні значення твердості властиві центральній частині ядра зварних з'єднань, а також світлим овальним концентричним фрагментам структури верхньої та нижньої частини ядра. За наявністю в ядрі нанорозмірної зміцненої структури та рівномірності її розподілу, а також хорошому розсіюванню оксидних плівок і суцільності з'єднання, оптимальним можна вважати зварювання тертям з перемішуванням інструментом С-типу. Зроблено припущення, що формування рівномірної структури в зварних швах можна отримувати за три-чотири оберта зварюванням тертям 3 перемішуванням інструменту на одному місці. Бібліогр. 21, табл. 1, рис. 7

Ключові слова: зварювання тертям з перемішуванням, зона термомеханічного впливу, ядро зварного шва, індентування, індентор Берковича, модуль Юнга, фізико-механічні властивості 


\title{
INFLUENCE OF THE SHAPE OF THE TOOL FOR FIRCTION STIR WELDING ON PHYSICO-MECHANICAL PROPERTIES OF WELDS OF ALUMINIUM ALLOY EN AW 6082-T6
}

K. Krasnovski ${ }^{1}$, Yu.A. Khokholova ${ }^{2}$, M.A. Khokholov ${ }^{2}$

${ }^{1}$ Institute of Welding, 16-18 B1. Czeslava str., Gliwice, 44-100, Poland

${ }^{2}$ E.O. Paton Electric Welding Institute of the NAS of Ukraine.

11 Kazymyr Malevych Str., 03150 Kyiv, Ukraine. E-mail: office@paton.kiev.ua

\begin{abstract}
The paper presents the results of studying the formation of macrostructure and distribution of mechanical properties in welded joints of flat samples from aluminium alloy EN AW 6082-T6 $8 \mathrm{~mm}$ thick, produced by the method of friction stir welding with application of three types of specially designed pins with shoulders: $\mathrm{C}$ - cylindrical threaded pin and shoulder with a spiral groove; $\mathrm{T}$ - cylindrical threaded pin with three grooves and shoulder with a spiral groove; $\mathrm{S}$ - smooth cylindrical pin without thread and flat shoulder. Friction stir welding was conduced in the equipment of the Institute of Welding in Gliwice (Poland), and treatment and mechanical testing were conducted at PWI. Mechanical testing by indentation was performed in Microngamma instrument, which allows experimental identification of the structural state of metal after refinement and determination of the presence of strain ageing by limit values of the ratio of hardness to Young's modulus of elasticity. It is found that for all the three samples HAZ hardness decreases, and in the thermomechanical impact zone hardness increases. Maximum hardness values are inherent to the central part of welded joint nugget, as well as to light-coloured oval concentrated fragments of the structure in the nugget upper and lower part. Judging by the presence of nanosized strengthened structure and uniformity of its distribution in the nugget, as well as good dispersion of oxide films and absence of discontinuities, friction stir welding with C-type tool can be regarded as the optimum variant. An assumption was made that formation of a uniform structure in welds can be achieved at three-four rotations of the tool in friction stir welding in one spot. 21 Ref., 1 Tabl., 7 Fig.
\end{abstract}

Keywords: friction stir welding, thermomechanical impact zone, weld nugget, indentation, Berkovich indender, Young's modulus, physico-mechanical properties

\section{Лащенко Г.И., Никитюк Ю.А. Расширение технологических возможностей сварочного производства. Киев, 2019. - 360 стр.}

Рассмотрена роль сварочного производства в развитии национальной экономики. Проанализировано состояние и пути трансформации украинской экономики. Освещены тенденции и тренды развития современного сварочного производства. Изложены основы разработки технологии сварки. Дана характеристика способов и приемов сварки плавлением. Проанализировано использование принципа комбинирования для расширения технологических возможностей заготовительных, сборочных и сварочных операций.

Приведены технологические возможности сварки трением с перемешиванием и родственных процессов. Освещены особенности малоэнергоемких технологий послесварочной обработки металлоконструкций с помощью вибронагружения и поверхностного пластического деформирования.

Для инженерно-технических работников, занятых в сварочном производстве. Может быть полезна преподавателям, аспирантам и студентам сварочных специальностей вузов.

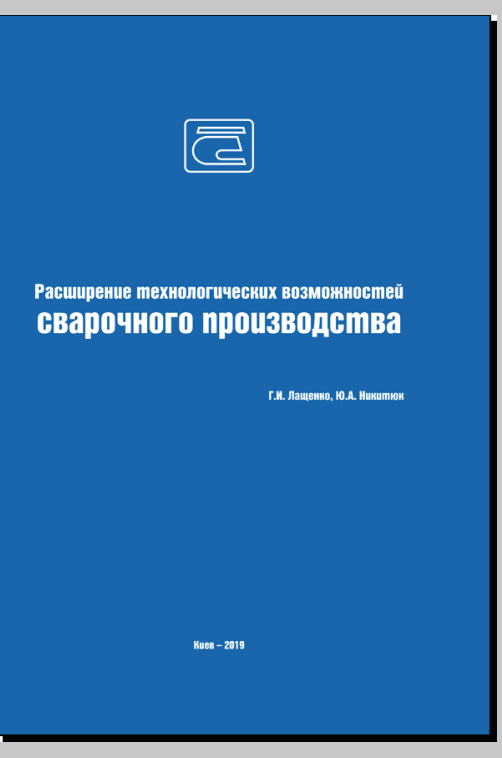

Заказы на книгу просьба направлять в редакцию журнала «Автоматическая сварка» (тел. 200-82-77). 


\title{
МОДЕЛИРОВАНИЕ ТЕМПЕРАТУРНЫХ ПОЛЕЙ, НАПРЯЖЕНИЙ И ДЕФОРМАЦИЙ В ЦИЛИНДРИЧЕСКИХ ОБОЛОЧКАХ, ПОЛУЧЕННЫХ МЕТОДОМ АДДИТИВНОЙ ТЕХНОЛОГИИ*
}

\begin{abstract}
В.А. Костин, Г.М. Григоренко
ИЭС им. Е.О. Патона НАН Украины. 03150, г. Киев, ул. Казимира Малевича, 11. E-mail: office@paton.kiev.ua В работе представлены результаты моделирования температурных полей, напряжений и деформаций при формировании аддитивной многослойной конструкции из алюминиевого сплава 1561 , низколегированной конструкционной стали марки 09Г2С и титанового сплава марки Grade 2. На основании экспериментальных результатов, полученных ранее в ИЭС им. Е.О. Патона при нанесении аддитивных наплавок из данных материалов, было проведено компьютерное моделирование для улучшения технологии проведения аддитивного процесса. В ходе расчетов было проанализировано влияние алгоритма последовательности нанесения аддитивных слоев — наплавление цилиндрической оболочки по кольцу или по спирали - на распределение температур в наплавке и ее устойчивость к внешним нагрузкам. Установлено, что при формировании цилиндрических оболочек аддитивным методом целесообразно использовать технологию наплавления по спирали и применять менее теплопроводные конструкционные материалы - конструкционные стали и титановые сплавы. Библиогр. 10, рис. 7.
\end{abstract}

Ключевые слова: аддитивное производство, моделирование, наплавление по спирали, ичилиндрические оболочки, устойчивость, остаточные напряжения

В современном строительстве, авиационной и космической технике, а также в ряде других областей промышленного производства большое значение имеет использование тонкостенных оболочек из различных материалов [1]. Такие оболочки могут использоваться как корпуса ракетных двигателей твердого топлива, строительные куполообразные сооружения, резервуары для хранения активных и криогенных жидкостей, т.е. как конструкции, работающие при высоких внутренних давлениях при осесимметричной внешней нагрузке.

В качестве сырья для их производства часто используются различные конструкционные стали, титановые и алюминиевые сплавы, композитные материалы на основе титана, алюминия и керамики.

Использование тонкостенных оболочек позволяет значительно снизить массу конструкции при сохранении максимального объема, обеспечить ее необходимую прочность и жесткость, использовать самые разнообразные сложные формы при проектировании изделий различных типов.

Традиционно такие оболочки получают методом инструментальной или магнито-импульсной штамповки, электрогидравлической штамповкой или штамповкой взрывом, ротационной вытяжки,

\footnotetext{
* По материалам доклада, представленного на Международной конференции «Материалы для сварки, наплавки, нанесения покрытий и 3D-технологий», 04-05 июня 2019 г., г. Киев.
}

(C) В.А. Костин, Г.М. Григоренко, 2019 изгиба тонколистового проката и последующего соединения его краев сваркой [2].

В случае использования оболочек переменной толщины возникает проблема удаления излишков материала. Это достигается путем механического фрезерования или химического травления, что значительно увеличивает продолжительность процесса его изготовления и значительно увеличивает стоимость производства. Механические дефекты, возникающие в ходе этих операций, делают его непригодным для восстановления путем ремонта.

Возобновление интереса к изучению тонкостенных конструкций обусловлено не только появлением новых материалов и сплавов, бурным развитием компьютерных технологий, но и возможностью использования новых методов получения деталей и их компонентов с помощью аддитивных технологий $[3,4]$.

В настоящее время многие мировые компании при изготовлении своей продукции начали использовать аддитивную технологию для 3D-печати. В начале 2018 г. известная американская аэрокосмическая корпорация Lockheed Martin представила [5] первый напечатанный на 3D-принтере бак для ракетного топлива из титанового сплава (рис. 1).

Выбор титана был обусловлен его высокой удельной прочностью, термостойкостью и коррозионной стойкостью. При использовании традиционных технологий производства цилиндриче- 


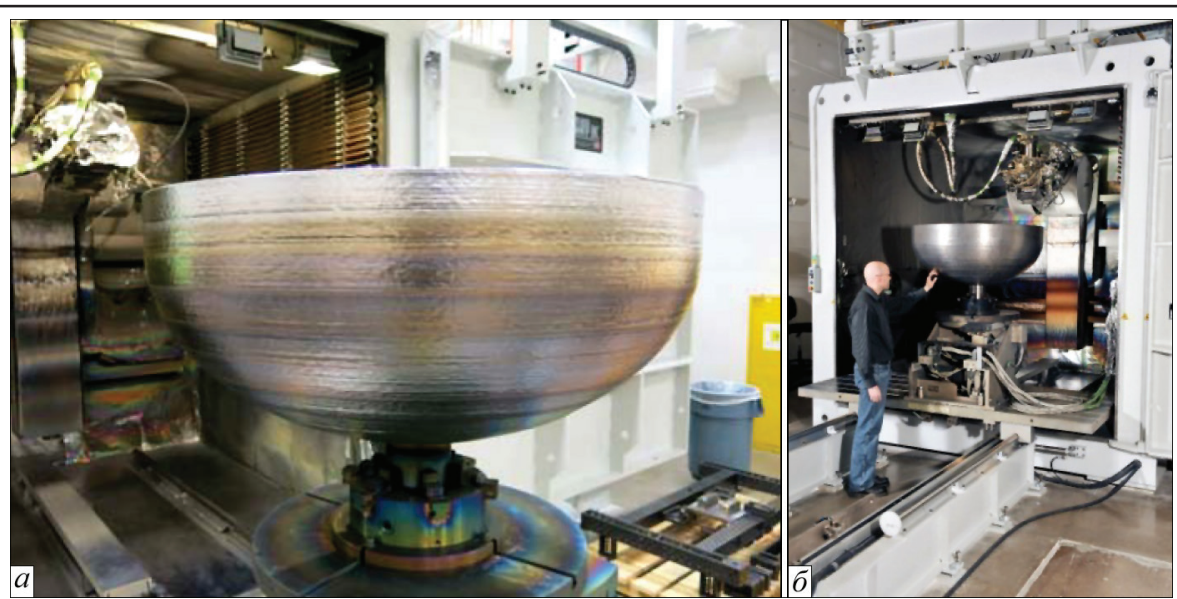

Рис. 1. Бак ракетного топлива (a) и электронно-лучевая камера для 3D-печати (б) [5]

ских топливных баков, как правило, до 70...80 \% ценного материала направляется на перерабатываемые отходы. Новый способ печати от Lockheed Martin позволяет в значительной степени (по данным компании до 87 \%) экономить на производстве этих баков.

Цилиндрические топливные баки - не единственное изделие Lockheed Martin, напечатанное на 3D-принтере. Компания уже использовала эту технологию для создания спутниковой системы связи и компонентов для межпланетной станции NASA Juno. Компания также планирует изготовить внешнюю оболочку для космического корабля «Орион» с использованием технологии 3D-печати.

Аддитивные технологии - это новый высокоэффективный метод создания деталей и конструкций, основанный на добавлении небольших порций материала. Изделия и материалы создаются путем плавления металлического порошка [4], сплошной проволоки или порошковой проволоки [6] концентрированными источниками нагрева.

Использование металлической проволоки вместо порошка в аддитивном процессе позволяет повысить производительность металлургических процессов, обеспечить более высокую энергоэффективность, повысить коэффициент использования материала, снизить остаточные напряжения и деформации, обеспечить необходимый уровень свойств. Использование аддитивного метода при ремонте тонкостенных оболочек может позволить восстановить их структурную целостность и несущую способность. В то же время создание работающей тонкостенной конструкции требует предварительного лабораторного исследования и компьютерного моделирования.

Целью представленной работы было усовершенствование технологии создания тонкостенных оболочек аддитивным методом на основе выбора геометрии их нанесения.
Методика эксперимента. В связи с тем, что тонкостенные конструкции широко используются в аэрокосмической технике, судостроении и промышленном строительстве, первоначально, для исследований были выбраны два типа материалов: титановый сплав марки Grade 2 и конструкционная низколегированная сталь марки 09Г2С.

В связи с особенностями формирования конструкций из титановых сплавов (высокая мощность источника нагрева, наличие высокого вакуума в камере нанесения) использовали специализированную систему аддитивного наплавления xBeam 3D Metal Printing [7]. Система основана на применении полого конического электронного луча в качестве источника нагрева и использовании проволоки в качестве расходуемого материала. Это создает благоприятные условия для расплавления расходуемого материала и его послойного контролируемого наплавления.

Для наплавки изделий из конструкционной стали использовалась дуговая система для создания аддитивных структур [8]. Она основана на использовании сварочного робота «АВB IRB-1600». В Институте электросварки им. Е.О. Патона разработано программное обеспечение для создания трехмерной модели, основанной на сканировании аддитивного покрытия, планировании траектории движения сварочной горелки с учетом коррекции данных лазерно-телевизионных и видеопирометрических датчиков.

Тонкостенные изделия из исследованных материалов показаны на рис. 2. В качестве материала для аддитивной наплавки трехмерных изделий использовались сварочные проволоки соответствующего состава и толщины.

С целью улучшения технологии создания тонкостенных оболочек аддитивным методом и повышения их механических свойств было проведено компьютерное моделирование.

Для моделирования был использован титановый сплав марки Grade 2 (BT1-0), содержащий, мас. \%: 


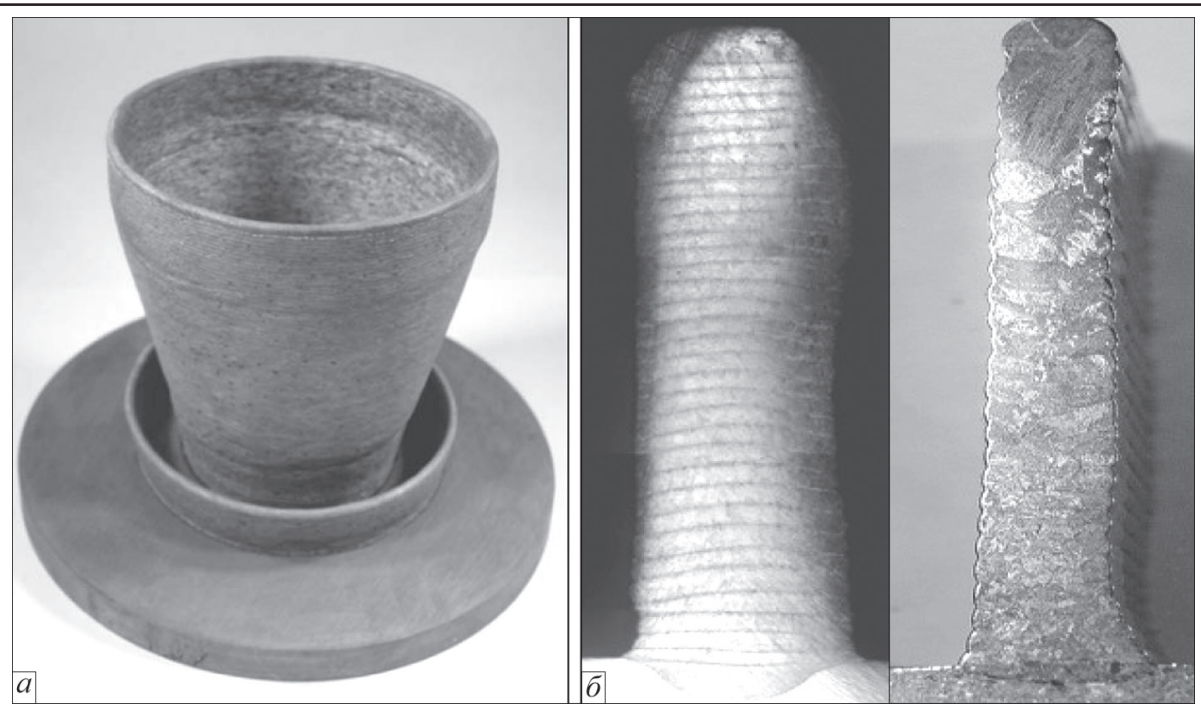

Рис. 2. Наплавки из исследуемых материалов, полученные аддитивным методом: $a$ - низколегированная сталь марки 09Г2С; 6 - титановый сплав марки Grade 2

0,03 N; 0,1 C; 0,25 O; 0, 3 Fe. Предел текучести сплава составлял $275 \mathrm{MПа,} \mathrm{предел} \mathrm{прочности} 345 \mathrm{MПа.}$ В качестве низколегированной стали была выбрана сталь марки 09Г2С, применяемая для сварных конструкций, содержащая, мас. \%: 0,12 C; $0,6 \mathrm{Si} ; 1,5$ $\mathrm{Mn} ; 0,3 \mathrm{Cu} ; 0,04 \mathrm{~S} ; 0,003$ P. Предел текучести стали составлял 345 МПа, предел прочности 490 МПа, относительное удлинение $21 \%$.

В связи с тем, что в практике создания цилиндрических оболочек для аэро- и ракетно-космической техники широко распространено использование высокопрочных алюминиевых сплавов, было целесообразно применить разработанные подходы к анализу создания аддитивных оболочек для данных сплавов.

В связи с ограничением доступа к экспериментальным результатам в этой отрасли, в качестве прогнозируемого варианта было проведено моделирование электродуговой наплавки проволокой тонкостенного изделия из деформируемого алюминиевого сплава марки 1561 (АМг61) в защитной среде аргона. Сплав марки 1561 содержит, мас. \%: 6,1 Mg; 0,9 Mn; 0,4 Si; 0,4 Fe; 0,003 Be; $0,12 \mathrm{Zr}$. Данный сплав широко применяется при производстве тонкостенных элементов аэрокосмической техники. Алюминиевый сплав имеет предел текучести не менее $250 \mathrm{MПа,} \mathrm{а} \mathrm{предел} \mathrm{проч-}$ ности - не менее 360 МПа.

Рассчитываемые цилиндрические оболочки представляют собой последовательно наносимые на подложку по кругу с радиусом 20 мм слои материала шириной 2 мм и толщиной слоя 2 мм. Количество нанесенных слоев должно удовлетворять условию тонкой стенки, т. е. оболочка считается тонкой, если $h / R \leq 1 / 10 \ldots 1 / 20$. Исходя из выбранных параметров, это условие было выполнено, когда количество слоев превышает 10.
Технологические параметры аддитивного наплавления

Мощность источника нагрева (Al/Fe/Ti), кВт ............. 0,6/1/5 Толщина пластины, мм.............................................................

Толщина наплавляемого слоя, мм .......................................2

Ширина наплавки, мм.........................................................2

Радиус наплавки, мм...........................................................20

Высота наплавки, мм ...........................................................40

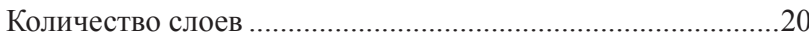

Скорость перемещения дуги, об/с .......................... 0,1; 0,2; 1

Количество наплавляемых слоев ..................................20...230

Выбор мощности дугового источника нагрева определялся характерными режимами сварки для данного типа материала: электронно-лучевой сваркой титановых сплавов (5 кВт), дуговой сваркой в среде защитных газов низколегированных сталей $(1$ кВТ) и дуговой сваркой алюминиевого сплава плавящимся электродом (0,6 кВт).

Исследовалось два способа нанесения аддитивных слоев - по кольцу и по спирали. Угловая скорость наплавления одного слоя определялась технологическими возможностями установок и составляла 0,$1 ; 0,5$ и 1 об./c.

Расчетная модель. Для моделирования влияния способа нанесения наплавки на ее свойства были рассчитаны температурные поля и напряженно-деформированное состояние цилиндрических изделий в процессе их формирования. Для расчетов использовался вычислительный пакет COMSOL Multiphysics ${ }^{\circledR}$. Математическая модель аддитивного процесса была представлена в работах $[9,10]$. На основании экспериментальных результатов было принято, что в начальный момент времени осажденный материал находится в твердо-жидком состоянии между температурами жидкости и твердого тела. По этой причине в расчетах можно пренебречь жидкой фазой.

Для численного анализа кинетики изменения температурного поля в наплавляемой оболочке 
решалось трехмерное нестационарное уравнение теплопроводности:

$$
\rho C_{p}\left(\frac{\partial T}{\partial t}+u \nabla T\right)=\nabla[k(T) \nabla T],
$$

где $\rho C_{p}$ - удельная теплоемкость; $k$ - коэффициент теплопроводности материала.

Граничные условия, необходимые для решения уравнения (1), определяются балансом подводимого тепла и теплоотвода от поверхности осаждаемой детали. Передача тепла в области контакта наплавляемого изделия с подложкой может быть описана законом Ньютона, тогда как тепловое излучение на свободной поверхности регулируется законом Стефана-Больцмана. Граничные условия для решения уравнения теплопроводности (1) имеют следующий вид (2):

$$
-k(T) \frac{\partial T}{\partial n}=\left\{\begin{array}{l}
\left\{h\left(T-T_{\text {ext }}\right),\right. \text { в области контакта } \\
h\left(T-T_{\text {ext }}\right)+\varepsilon \sigma_{0}\left(T^{4}-T_{\text {ext }}^{4}\right)-q_{\text {arc }}-q_{\text {wire }}, \\
\text { на свободной поверхности }
\end{array}\right.
$$

где $n$ - нормаль к поверхности; $h=10$ (Вт/м² коэффициент конвективной теплопроводности; $\varepsilon=0,8$ - коэффициент излучения материала; $\sigma_{0}$ - постоянная Стефана-Больцмана $\left(5,6 \cdot 10^{-8}\right.$ Дж $\left.\mathrm{c}^{-1} \mathrm{M}^{-2} \mathrm{~K}^{-4}\right) ; T_{\text {ext }}=293 \mathrm{~K}$ - температура окружающей среды; $q_{\text {arc }}$ - плотность теплового потока,

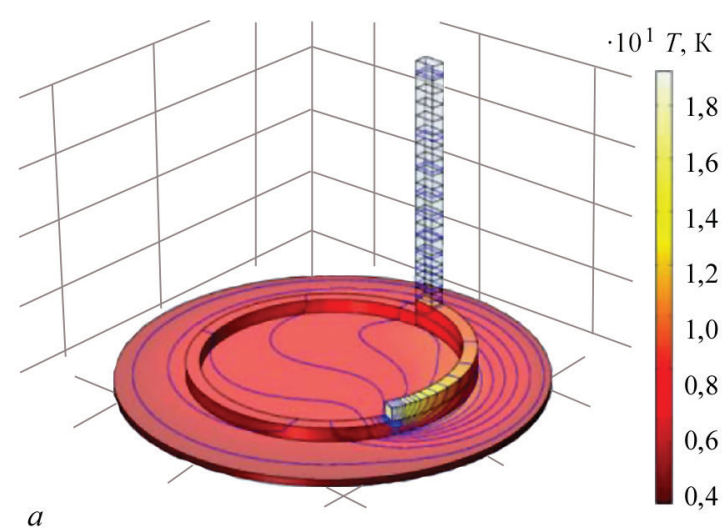

$a$

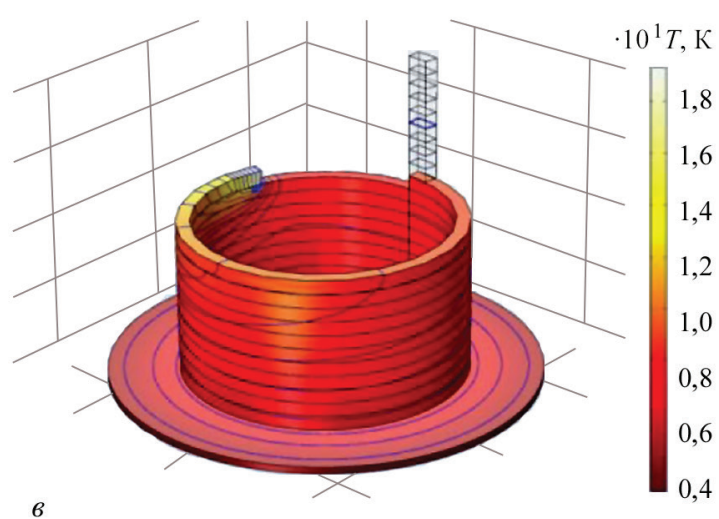

создаваемого дуговым источником тепла (Вт/м²); $q_{\text {wire }}$ - плотность теплового потока, создаваемого расплавленной проволокой (ВТ/ $\left.\mathrm{M}^{2}\right)$.

В работе использована модель совместной передачи энергии от двух одновременно действующих источников тепла, а именно от источника дуги и расплавленной проволоки. Координаты дуги, движущейся по поверхности, задаются уравнением (3):

$$
X=X_{\mathrm{g}}+R \cos (2 \pi \omega t) ; Y=Y_{\mathrm{g}}+R \sin (2 \pi \omega t)
$$

где $X_{\mathrm{g}}, Y_{\mathrm{g}}$ - начальное положение дуги; $\omega$ - угловая скорость; $R$ - радиус траектории; $t$ - время.

Распределение плотности теплового потока движущейся дуги $q_{\text {arc }}(X, Y, t)$ было задано уравнением (4):

$$
\begin{aligned}
& q_{\text {arc }}(x, y, t)=q_{\text {max }} \times \\
& \times \exp \left[-K_{x}\left(\frac{X-X \mathrm{~g}}{R}\right)^{2}-K_{y}\left(\frac{Y-Y_{\mathrm{g}}}{R}\right)^{2}\right],
\end{aligned}
$$

где $X, Y$ - координаты источника тепла; $q_{\max }=$ $=\eta U_{a} I_{w}-$ мощность дуги; $\eta-$ коэффициент полезного действия $(0,9 \ldots 0,95)$ источника; $U_{a}-$ напряжение дуги; $I_{w}$ - ток дуги; $K_{x}, K_{y}$ - коэффициенты концентрации удельного источника тепла.

Распределение плотности теплового потока от расплавленной проволоки $q_{\text {wire }}(X, Y, t)$ задавалось движением кромки формирующего слоя с угло-
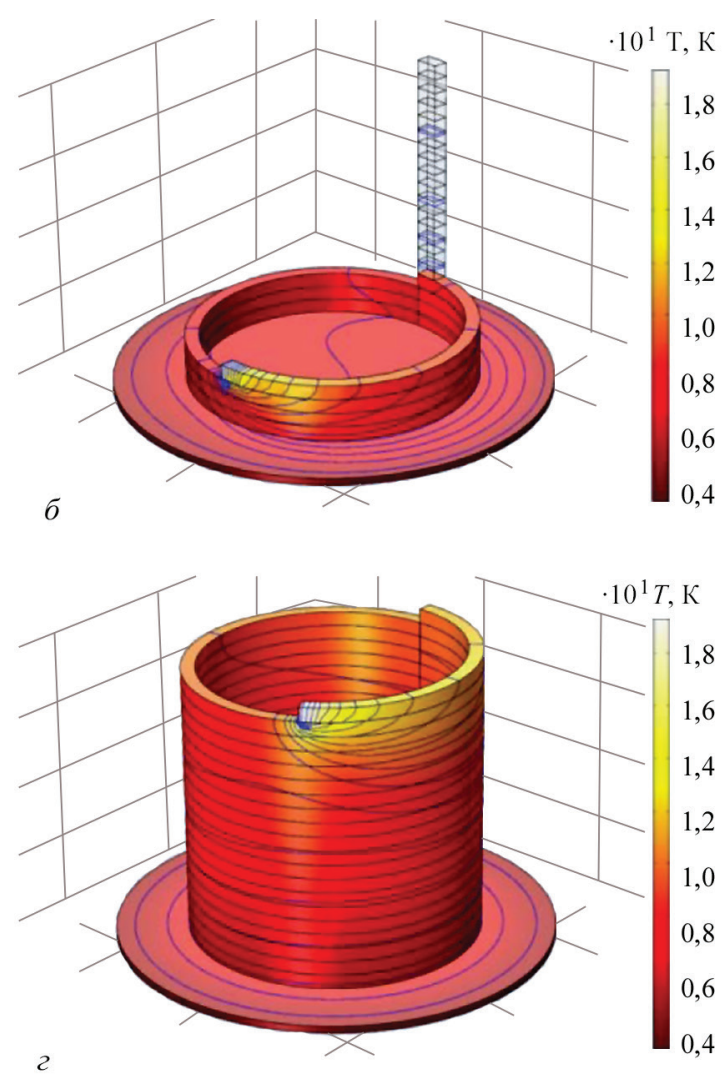

Рис. 3. Распределение температуры в цилиндрической оболочке из титанового сплава Grade 2 получаемой со скоростью 0,1 об/с по времени: $a-13$ с; $\sigma-35 ;$; $-108 ; 2-194$ 

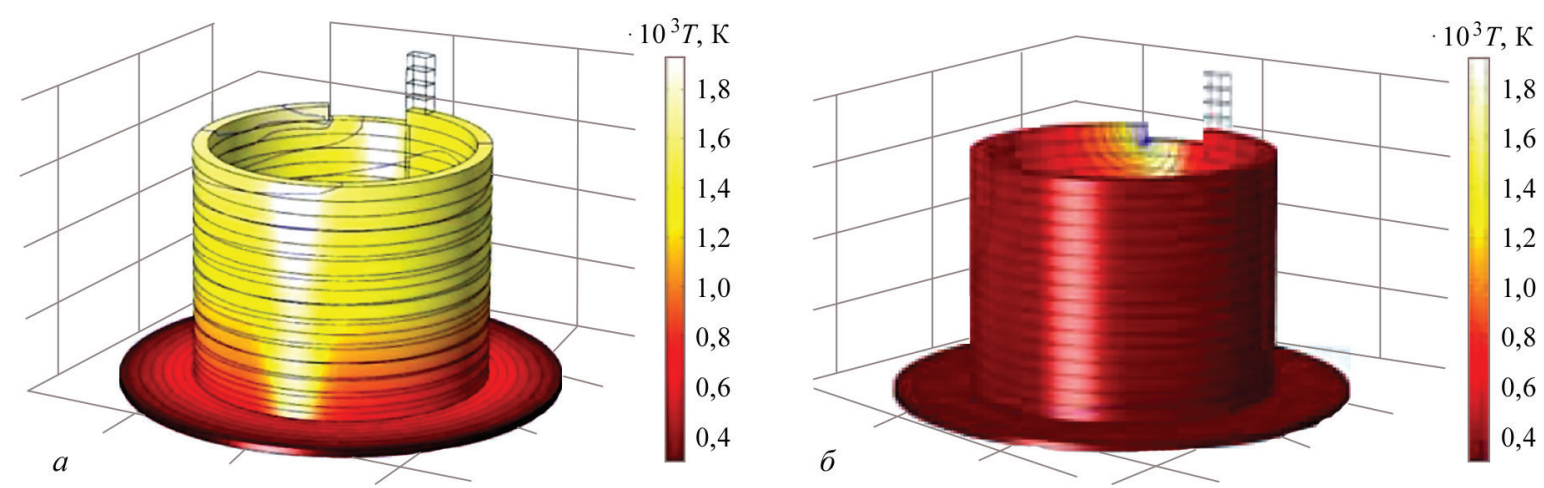

Рис. 4. Влияние материала наплавки на температурное поле в оболочке: $a$ - сплав 1561 ; $\sigma$ - Grade 2

вой скоростью омега при постоянной температуре $T_{\text {wire }}=T_{\text {melt }}$. Для исследованных материалов $T_{\text {melt }}$ составляла 625,1504 и $1716^{\circ} \mathrm{C}$ для алюминиевого сплава 1561, стали марки 09G2S и титана марки 2 соответственно.

Результаты моделирования. В результате моделирования были рассчитаны поля температур, напряжений, деформаций и перемещений при формировании цилиндрических оболочек аддитивным методом.

Температурные поля в оболочке из титанового сплава Grade 2 во времени показаны на рис. 3 . Анализ показал практически равномерное распределение температуры по толщине нанесенного слоя. Распределение температур по высоте оболочки показало, что она не изменяется в процессе наплавки 9...10 слоев. Температура подложки не превышает $200 \ldots 230{ }^{\circ} \mathrm{C}$, и, следовательно, ее структурно-фазовое состояние не меняется.

Расчеты показывают, что наиболее быстрая стабилизация температуры оболочки наблюдается при сварке проволокой из стали 09Г2С - через $35 . .40$ с. Для алюминиевого сплава 1561 это время составляет $65 \ldots 70$ с., тогда как для титанового сплава Grade 2 стабилизации не происходит.

Расчеты показывают, что в зависимости от состава используемой проволоки максимальная температура наплавки превышала температуру плавления данного материала на $50 \ldots 75^{\circ} \mathrm{C}$ (для алюминиевого сплава 1561 ), на $100 \ldots 150^{\circ} \mathrm{C}$ (для стали 09Г2С) и на $200{ }^{\circ} \mathrm{C}$ (для титанового сплава Grade 2).

Анализ распределения температур по высоте наплавки показывает (рис. 4), что в зависимости от типа используемого материала влияние расплавленной проволоки на уже нанесенные слои наплавки различно. Так, наибольшее влияние в результате воздействия предыдущих слоев достигается при наплавке алюминиевого сплава 1561, которое распространяется на нижележащие 8...10 слоев (рис. $4, a$ ). При нанесении расплавленной проволоки из стали 09Г2С или титанового сплава Grade 2 это влияние существенно ниже. Для стали оно составляет $3 . .44$ слоя, для титанового сплава $1 \ldots 2$ слоя (рис. 4,6 ). Полученные результаты объясняются заметно более высокой теплопроводностью алюминиевого сплава $(100 \ldots 150 \mathrm{BT} /(\mathrm{m} \cdot \mathrm{K}))$ по сравнению со сталью $(23 \ldots 28 \mathrm{BT} /(\mathrm{M} \cdot \mathrm{K}))$ или титановым сплавом $(17 \ldots 25 \mathrm{BT} /(\mathrm{m} \cdot \mathrm{K}))$.

Цилиндрическая конструкция из алюминиевого сплава 1561 остывает заметно быстрее и повторный разогрев достигает более глубоких слоев, что приводит к росту размера зерна и снижению механических свойств из этих сплавов. Использование в аддитивном процессе стали 09Г2С и титанового сплава Grade 2 приводит к формированию более однородной структуры наплавки и снижает остаточные напряжения, образующиеся при формировании цилиндрической оболочки.

В ходе расчетов было проанализировано влияние алгоритма нанесения аддитивной цилиндрической наплавки - наплавление по кольцу или по спирали - на температуру наплавки и параметры устойчивости аддитивной оболочки к внешним нагрузкам (рис. 5).

В большинстве работ по моделированию аддитивной наплавки эффект формы наплавки не учитывается. Это связано с тем, что в этом случае в расчетах необходимо учитывать гидродинамику капли, процессы кристаллизации, взаимодействие капель между собой и т. д. Для того, чтобы избежать этих сложностей и приблизиться к реальной геометрии наплавки форма нанесенного слоя по

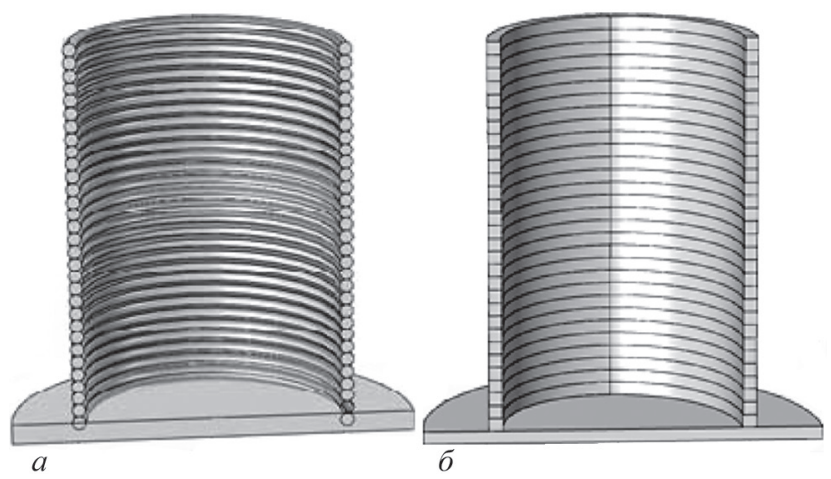

Рис. 5. Характер нанесения аддитивных слоев: $a-$ по спирали; б - по кольцу 
сечению задавалась заранее. В большинстве случаев вид боковой поверхности оболочки имеет волнообразный «ребристый» характер, причем он зависит от толщины слоя и скорости наплавления.

В ходе работы было принято, что при спиралевидной наплавке формируется волнообразная геометрия боковой стенки, тогда как при наплавке по кольцу - плоская. Это предположение обосновано тем, что реальная наплавка осуществляется непрерывно по всей высоте изделия и при этом формируется «ребристая» поверхность, тогда как наплавка по кольцу более идеализированный вариант, который используется для расчетов.

Анализ полученных результатов показал, что спиралевидная наплавка нагревается до более высоких температур по сравнению с кольцевой наплавкой. Это, по-видимому, связано с пониженной передачей тепла между слоями. При этом наплавленный слой быстрее остывает, что определяется большей площадью охлаждаемой поверхности.

Параметры охлаждения цилиндрической оболочки менее теплопроводного титанового сплава Grade 2 по сравнению с оболочкой из стали 09Г2С обеспечивают более высокие уровни температур. Как, следствие, возможно повышение перегрева жидкой ванны и выход из диапазона температур твердожидкого состояния для данного сплава $\left(T_{\text {sol }} / T_{\text {liq }}\right)$ Tем самым повышается риск «протекания» жидкого расплава по боковой поверхности цилиндрической оболочки.

В работе было проанализировано различие в механической устойчивости цилиндрических аддитивных оболочек, полученных различными методами.

При анализе устойчивости цилиндрических оболочек, полученных аддитивным методом, необходимо принимать во внимание наличие остаточных напряжений, которые формируются на границе нанесенных слоев. В случае нанесения слоев по кольцу остаточные напряжения на границах составляют $40 \ldots 50 \mathrm{MПа,} \mathrm{в} \mathrm{то} \mathrm{время} \mathrm{как} \mathrm{при}$ нанесении слоев по спирали остаточные напряжения оказываются несколько ниже и составляют 10 ...30 МПа. При этом, как показали предыдущие исследования [10], наибольший уровень напряжений наблюдается на границе аддитивных слоев и подложки. В этом случае уровень напряжений составляет $100 \ldots 150$ МПа.

Характер распределения напряжений в цилиндрических оболочках, полученных различными методами, под действием осевой сжимающей нагрузки $P=50$ МПа приведен на рис. 6. Как видно из приведенных результатов, наличие напряжений, образующихся в процессе аддитивного наплавления, изменяет в целом характер распределения напряжений в оболочках под действием осевой сжимающей нагрузки.

Анализ полученных результатов (рис. 6) показывает, что характер формирующихся напряжений существенным образом зависит от способа формирования оболочки. Отличия, прежде всего, заключаются в уровне напряжений, образующихся в них. Наибольшие напряжения (55...60 МПа) формируются в оболочке, выполненной кольцевыми слоями, тогда как наименьшие (35...40 МПа) формируются в многослойной наплавке, выполненной по спирали. Этот результат, возможно, объясняется некоторым демпфированием внешней осесимметричной нагрузки слоями наплавки, расположенной по спирали.

Анализ устойчивости оболочек, полученных различными методами, к действию осевой сжимающей нагрузки представлен на рис. 7. Под потерей устойчивости подразумевалась потеря формы конструкции под действием внешних сил. Для определения начала образования пластических деформаций использовалось условие текучести по Мизесу (5):
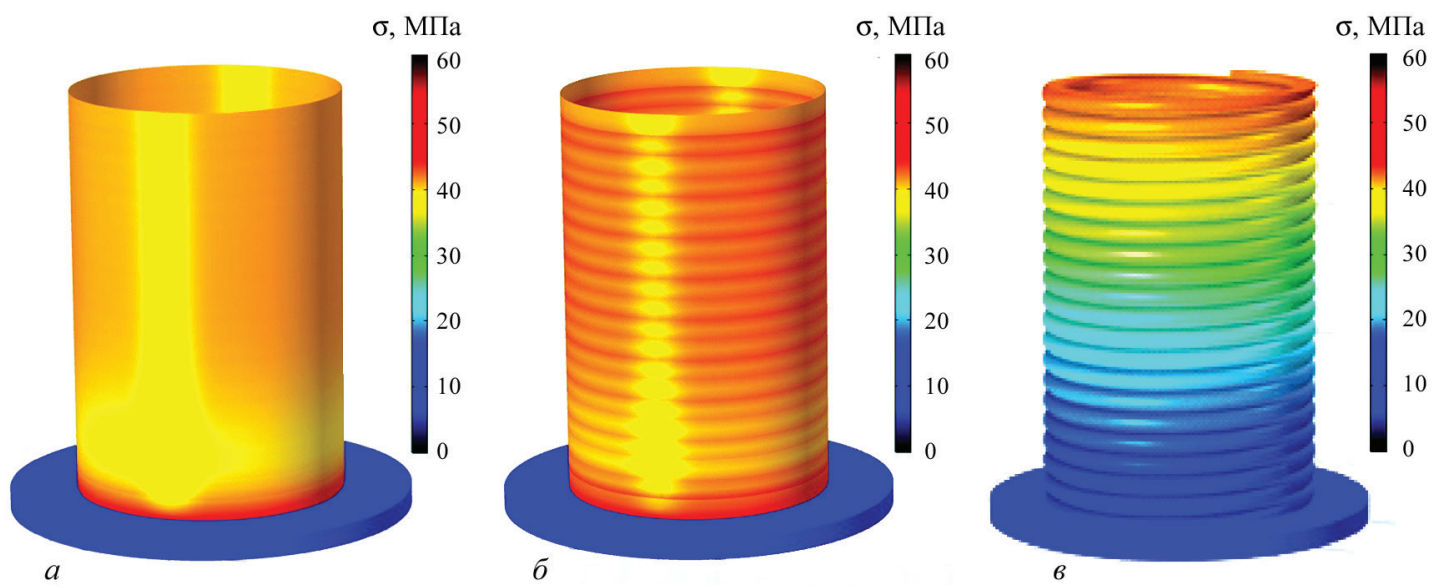

Рис. 6. Распределение эквивалентных напряжений в цилиндрических оболочках из титанового сплава Grade 2 под действием осевой нагрузки $P=50$ МПа, полученных различными методами: $a$ - традиционным из листа; $\sigma$ - многослойной наплавкой по кольцу; в - многослойной наплавкой по спирали 


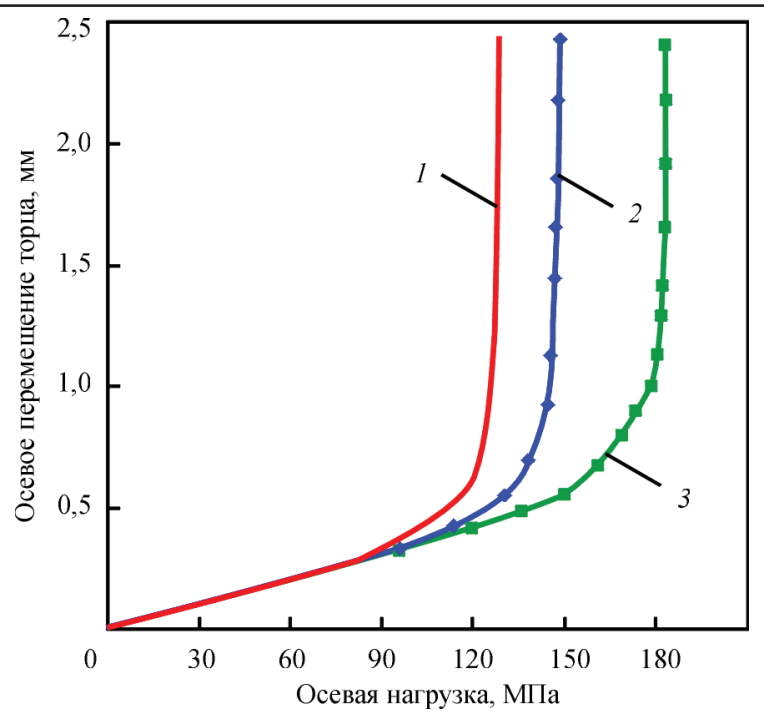

Рис. 7. Устойчивость цилиндрических оболочек, полученных различными методами, к действию осевой сжимающей нагрузки: 1 - из сплошного листа; 2 - из многослойной наплавки по кольцу; 3 - из многослойной наплавки по спирали

$$
\begin{aligned}
& g(\sigma)=\sqrt{\frac{1}{2}\left(\frac{\left(\sigma_{1}-\sigma_{2}\right)^{2}+\left(\sigma_{2}-\sigma_{2}\right)^{2}+\left(\sigma_{1}-\sigma_{3}\right)^{2}}{\sigma_{\mathrm{T}}^{2}}\right)}- \\
& -1 \geq 0
\end{aligned}
$$

где $\sigma_{1}, \sigma_{2}, \sigma_{3}$ - главные нормальные напряжения; $\sigma_{\mathrm{T}}$ - предел текучести.

Исследование цилиндрических оболочек, выполненных различными методами, показало, что при многослойной наплавке по спирали достигается наибольший уровень критических напряжений (180..200 МПа), при которых она теряет устойчивость по сравнению с оболочками, полученными из сплошного листа (150...165 МПа) и многослойной наплавкой по кольцу (145...150 МПа).

Таким образом, на основании проведенной работы можно заключить, что при формировании цилиндрических оболочек аддитивным методом целесообразно использовать технологию аддитивного наплавления по спирали.

\section{Список литературы}

1. Кривошапко С.Н. (2013) О возможностях оболочечных сооружений в современной архитектуре и строительстве. Строительная механика инженерных конструкиий и сооружений, 1, 51-56.

2. Барвинок В.А., Кирилин А.Н., Комаров А.Д. (2002) Bblсокоэффективные технологические проиессы изготовления элементов трубопроводных и топливных систем летательных аппаратов. Москва, Наука и технологии.
3. Григоренко Г.М., Шаповалов В.А., Жуков В.В. (2016) Аддитивное производство металлических изделий (Обзор). Автоматическая сварка, 5-6, 148-153.

4. Kaufui V.Wong, Aldo Hernandez. (2012) A Review of Additive Manufacturing. International Scholarly Research Network - Mechanical Engineering, 2012, Article ID 208760, 10 pages, Doi:10.5402/2012/208760.

5. ВМС США напечатали готовый к погружению подводный аппарат. https://hi-news.ru/technology/vms-sshanapechatali-gotovyj-k-pogruzheniyu-podvodnyj-apparat. html

6. Jandric Z., Labudovic M., Kovacevic R. (2004) Effect of heat sink on microstructure of three-dimensional parts built by welding-based deposition International Journal of Machine Tools and Manufacture, 44(7-8), 785-796.

7. Ковальчук Д.В., Мельник В.И., Мельник И.В., Тугай Б.А. (2017) Новые возможности аддитивного производства с технологией хBeam 3D Metal Printing (Обзор). Автоматическая сварка, 12, 26-33.

8. Шаповалов Е.В., Долиненко В.В., Коляда В.А. и др. (2016) Применение роботизированной и механизированной сварки в условиях возмущающих факторов. Там же, 7(754), 46-51.

9. Костин В.А., Григоренко Г.М. (2017) Особенности формирования структуры 3D изделия из стали S460M в аддитивной металлургической технологии. Современная электрометаллургия, 3(128), 33-42.

10. Костин В.А., Григоренко Г.М., Жуков В.В. (2017) Моделирование металлургического аддитивного процесса создания конструкций из стали 09Г2С. Там же, 2(127), $35-44$.

\section{References}

1. Krivoshapko, S.N. (2013) On possibilities of shell constructions in modern architecture and building. Stroit. Mekhanika Inzhen. Konstruktsij i Sooruzhenij, 1, 51-56 [in Russian].

2. Barvinok, V.A., Kirilin, A.N., Komarov, A.D. (2002) Highefficient technological processes of manufacturing of piping and fuel systems of aircrafts. Moscow, Nauka i Tekhnologii [in Russian].

3. Zhukov, V.V., Grigorenko, G.M., Shapovalov, V.A. (2016) Additive manufacturing of metal products (Review). The Paton Welding J., 5-6, 137-142.

4. Kaufui, V.Wong, Aldo Hernandez (2012) A review of additive Manufacturing. Ont. Scholarly Res. Network - Mechanical Engineering, Art. ID 208760, Doi: 10.5402/2012/208760.

5. NAVY USA printed the underwater apparatus ready to immersion. https://hi-news.ru/technology/vms-sshanapechatali-gotovyj-k-pogrusheniyu-podvodnyi-apparat. html

6. Jandric, Z., Labudovic, M., Kovacevic, R. (2004) Effect of heat sink on microstructure of three-dimensional parts build by welding-based deposition. Int. J. of Machine Tools and Manufacture, 44(7-8), 785-796.

7. Kovalchuk, D.V., Melnik, V.I., Melnik, I.V., Tugaj, B.A. (2017) New possibilities of additive manufacturing using xBeam 3D Metal Printing technology (Review). The Paton Welding J., 12, 16-22.

8. Shapovalov, E.V., Dolinenko, V.V., Kolyada, V.A. et al. (2016) Application of robotic and mechanized welding under disturbing factor conditions. Ibid., 7, 42-46.

9. Kostin, V.A., Grigorenko, G.M. (2017) Peculiarities of formation of 3D structure of S460M steel product in additive metallurgical technology. Sovrem. Elektrometall., 3, 33-42 [in Russian].

10. Grigorenko, G.M., Kostin, V.A., Zhukov, V.V. (2017) Modeling of metallurgical additive process of manufacture of 09G2S steel structures. Ibid., 2, 35-44 [in Russian]. 


\title{
МОДЕЛЮВАННЯ ТЕМПЕРАТУРНИХ ПОЛІВ, НАПРУГ ТА ДЕФОРМАЦІЙ У ЦИЛІНДРИЧНИХ ОБОЛОНКАХ, ОТРИМАНИХ МЕТОДОМ АДИТИВНОЇ ТЕХНОЛОГІЇ
}

\author{
В.А. Костін, Г.М. Григоренко
}

IE3 им. Є.О. Патона НАН України. 03150, м. Київ, вул. Казимира Малевича, 11. E-mail: office@paton.kiev.ua

В роботі представлено результати моделювання температурних полів, напружень та деформацій при формуванні адитивної багатошарової конструкції з алюмінієвого сплаву 1561, низьколегованої конструкційної сталі марки 09Г2С і титанового сплаву марки Grade 2. На підставі експериментальних результатів, отриманих раніше у IE3 ім. С.О. Патона при наплавленні адитивних шарів 3 даних матеріалів, було проведено комп’ютерне моделювання 3 метою підвищення продуктивності адитивного процесу. В ході розрахунків було проаналізовано алгоритм послідовності нанесення адитивних шарів - наплавлення циліндричної оболонки по кільцю або по спіралі — на розподіл температур в оболонці та параметри ії стійкості до зовнішніх навантажень. Встановлено, що при формуванні циліндричних оболонок адитивним методом доцільно використовувати технологію наплавлення по спіралі і застосовувати менш теплопровідні матеріали — конструкційні сталі та титанові сплави. Бібліогр. 10, рис. 7.

Ключові слова: адитивне виробництво, моделювання, наплавлення по спіралі, циліндричні оболонки, стійкість, залишкові напруги

\section{MODELLING OF TEMPERATURE FIELDS, STRESSES AND DEFORMATIONS IN CYLINDER CASINGS PRODUCED BY ADDITIVE MANUFACTURING METHOD}

\author{
V.A. Kostin, G.M. Grigorenko
}

E.O. Paton Electric Welding Institute of the NAS of Ukraineю 11 Kazimir Malevich Str., 03150, Kyiv, Ukraine.

E-mail: office@paton.kiev.ua

The paper presents the results of modelling of temperature fields, stresses and deformations in formation of additive multi-layer structure of aluminum alloy 1561, low-alloy structural steel of 09G2S grade and titanium alloy of Grade 2 grade. Based on the experimental results obtained earlier at the E.O. Paton Electric Welding Institute during application of additive deposits of these materials the computer modelling was carried out for improvement of technology of additive process. In course of calculations there was analyzed an effect of algorithm of sequence of additive layers deposition, namely deposition of cylinder casing on circle and on spiral, on distribution of temperatures in deposition and its resistance to external loads. It is determined that the spiral deposition technology is reasonable to be used in formation of cylinder casings by additive method and apply less heatconducting structural materials, i.e. structural steels and titanium alloys. 10 Ref., 7 Fig.

Keywords: additive manufacturing, modelling, spiral deposition, cylinder casings, resistance, residual stresses

Поступила в редакцию 08.04.2019

\section{Календарь выставок и конференций на 2019 г.}

\begin{tabular}{|c|l|l|}
\hline \multicolumn{1}{|c|}{ Дата } & \multicolumn{1}{|c|}{ Место проведения } & \multicolumn{1}{|c|}{ Название } \\
\hline 3-6 сентября & Томск, Россия & $\begin{array}{l}\text { Международная конференция «Сварка в России 2019: совре- } \\
\text { менное состояние и перспективы» }\end{array}$ \\
\hline 9-13 сентября & Одесса, Украина & $\begin{array}{l}\text { 9-я Международная конференция «Лучевые технологии в } \\
\text { сварке и обработке материалов» }\end{array}$ \\
\hline $\begin{array}{c}16-17 \\
\text { сентября }\end{array}$ & Росток, Германия & DVS - студенческий конгресс \\
\hline $14-16$ октября & Гданьск, Польша & 61-я научно-техническая конференция сварщиков \\
\hline 23-24 октября & София, Болгария & Семинар «Обучение персонала сварочного производства» \\
\hline 19-22 ноября & Киев, Украина & $\begin{array}{l}\text { 18-й Международный Промышленный Форум-2019 с разде- } \\
\text { лом «Укрсварка» }\end{array}$ \\
\hline
\end{tabular}




\title{
ЭФФЕКТИВНОСТЬ ПРИМЕНЕНИЯ ПРИСАДОЧНОЙ МЕТАЛЛОПОРОШКОВОЙ ПРОВОЛОКИ ПРИ ТIG-СВАРКЕ МЕДИ*
}

\begin{abstract}
В.М. Илюшенко, А.Н. Бондаренко, Е.П. Лукьянченко, Т.Б. Майданчук
ИЭС им. Е.О. Патона НАН Украины. 03150, г. Киев, ул. Казимира Малевича, 11. E-mail: office@paton.kiev.ua

Описан опыт создания в ИЭС им. Е.О. Патона металлопорошковой проволоки для гелиеводуговой сварки TIG меди и ее сплавов. Наплавленный металл проволоки содержит не более 0,35 мас. \% легирующих добавок и характеризуется высокой электро- и теплопроводностью. Приведены примеры эффективного применения разработанной проволоки при сварке роторов электромашин и ремонте газокислородных медных камер дуговых сталеплавильных печей. Библиогр. 2 , рис. 4.
\end{abstract}

Ключевые слова: сварка TIG, гелиевая защита, медь и медные сплавы, металлопорошковая проволока, электро- и теплопроводность, эффективность применения

Сварка в среде защитных газов является одним из основных технологических процессов соединения цветных металлов. Этому в значительной степени способствует наиболее простое решение задачи защиты металла сварочной ванны от окружающей атмосферы, возможность визуального наблюдения за процессом сварки, простота и надежность автоматизации процесса. Сварка меди за рубежом в основном выполняется данным способом.

В отечественной практике широкое применение, особенно для металла малых и средних толщин (до 10 мм), находит сварка неплавящимся электродом - TIG-процесс. В значительно меньшем объеме, в основном из-за отсутствия специальных сварочных проволок, используется сварка плавящимся электродом - MIG/MAG-процесс.

Сварка меди в среде защитных газов наряду с отмеченными преимуществами встречает и серьезные затруднения, а именно - необходимость применения предварительного, а при больших толщинах и сопутствующего подогрева, что существенно усложняет процесс сварки. Медь также склонна к повышенному образованию пор в сварных швах, которые возникают при кристаллизации сварочной ванны в результате выделения газов.

В качестве защитных газов для сварки меди применяют аргон, гелий, азот и их смеси. Учитывая особые теплофизические свойства меди, при выборе оптимальной защитной среды предпочтение следует отдавать гелию и азоту, обеспечивающим более высокий эффективный КПД процесса. Однако необходимо все же учитывать отрицатель-

\footnotetext{
* По материалам доклада, представленного на Международной конференции «Материалы для сварки, наплавки, нанесения покрытий и 3D-технологий», 04-05 июня 2019 г., г. Киев.
}

ное влияние азота на пористость швов при сварке меди и некоторых ее сплавов. Существовавшее ранее мнение об инертности азота по отношению к меди ошибочно. Последними исследованиями установлено, что в условиях сварочного нагрева азот абсорбируется жидкой медью и при кристаллизации сварочной ванны может приводить к образованию газовой пористости. Получение плотных швов при азотнодуговой сварке возможно при использовании присадочных материалов, содержащих элементы, связывающие азот в стойкие нитриды.

Принимая во внимание тот факт, что основной причиной пористости при сварке меди является образование и выделение из металла сварочной ванны паров воды в результате взаимодействия водорода с кислородом, основной мерой предупреждения пористости является активное раскисление металла сварочной ванны. Поэтому требуемое качество швов при сварке в среде защитных газов достигается прежде всего правильным выбором присадочного материала [1]. Анализ применения для сварки меди выпускаемых промышленностью по ГОСТ 16130-90 сварочных проволок (МНЖКТ 5-1-0,2-0,2; БрКМц3-1; БрХ0,7; БрХНТ и др.) показывает, что наличие в проволоках таких активных раскислителей и нитридообразующих элементов как титан, кремний, марганец и др., обеспечивает металлургическую обработку ванны и получение плотных бездефектных швов. Однако, несмотря на удовлетворительные сварочно-технологические свойства, эти проволоки не обеспечивают необходимых теплофизических свойств сварных соединений: тепло- и электропроводность их находится на уровне $20 \ldots 30 \%$ уровня таковых для свариваемого металла. Прак-

(C) В.М. Илюшенко, А.Н. Бондаренко, Е.П. Лукьянченко, Т.Б. Майданчук, 2019 


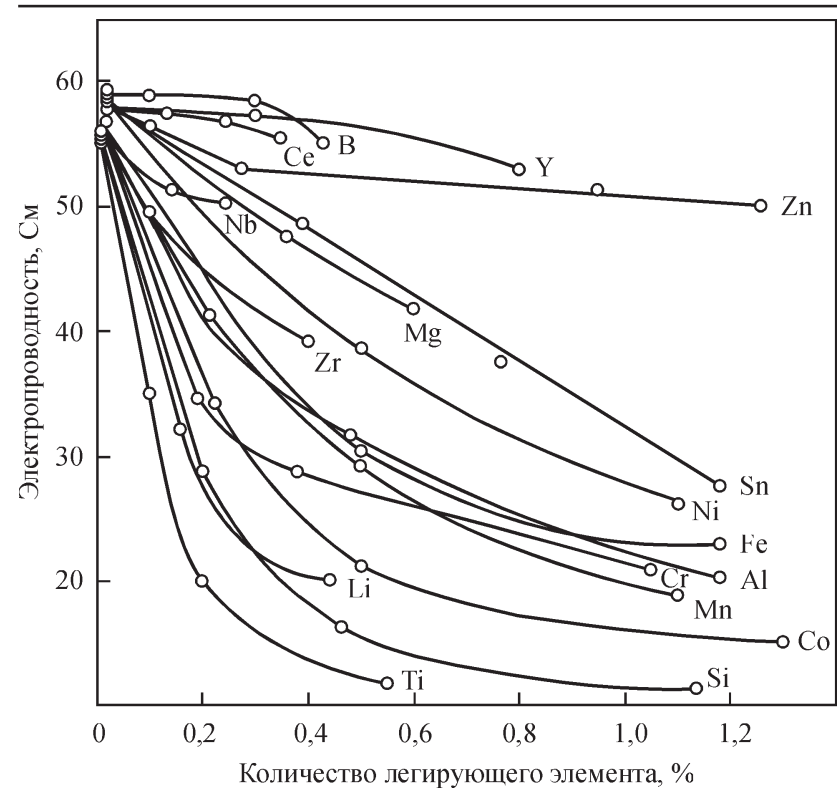

Рис. 1. Влияние добавок на электропроводность меди (по данным Института «Цветметобработка»)

тически эти материалы непригодны для сварки изделий, где требуется высокая электро- и теплопроводность сварных швов.

Как показывает опыт, такие же низкие показатели теплофизических свойств обеспечивает и выпускаемая за рубежом проволока OK Autrod19.12 (ERCu/AWSA5.7), у которой типичный химический состав наплавленного металла следующий, мас. \%: 0,2 Si, $0,2 \mathrm{Mn}$ и $0,8 \mathrm{Sn}$.

В ИЭС им. Е.О. Патона на протяжении многих лет совместно с Институтом «Цветметобработка» для сварки меди и ее низколегированных сплавов разрабатывались сварочные проволоки оптимальных химических составов, удовлетворяющих комплексу требований сварочно-технологических свойств при сварке как плавящимся, так и неплавящимся электродом, а также обеспечивающих необходимые теплофизические свойства сварных соединений. Созданы проволоки марок Св.МЛ0,2; Св.МБМг; Св.МЛМгБ; Св.МЛХМг, содержащие не более $0,1 \ldots 0,4 \%$ эффективных раскислителей и нитридообразующих элементов (литий, магний, бор). Как видно из рис. 1, такие небольшие добавки обеспечивают высокую электропроводность

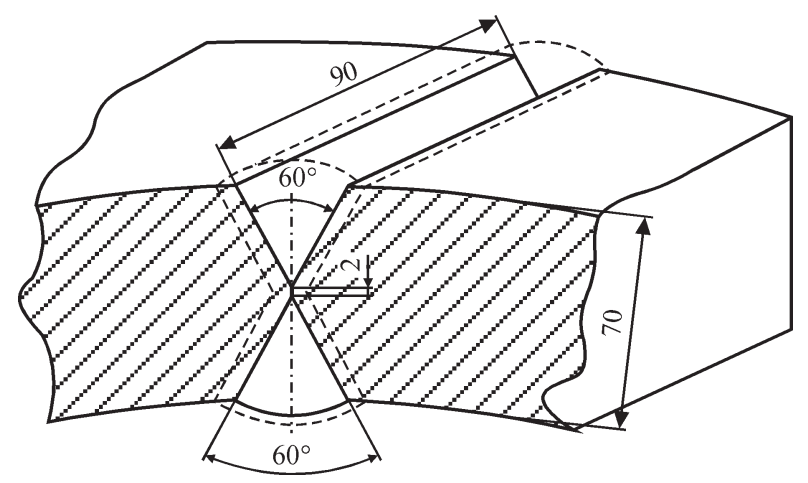

Рис. 2. Подготовка стыка для двусторонней сварки колец меди $(75 \ldots 85 \%$ от таковой для чистой меди). Однако технология изготовления этих проволок довольно сложная: плавка в вакуумных печах с использование лигатур, прессование прутков при высоком нагреве, отжиг и волочение до нужного диаметра, поэтому их выпуск налажен лишь в экспериментальном порядке [2].

Более простым и экономически целесообразным является создание электродного материала типа порошковой проволоки, применив при этом в качестве оболочки медную ленту. Используя ленту толщиной $0,8 \ldots 1,0$ мм и шириной $12 \ldots 15$ мм, а основным наполнителем сердечника медный порошок, мы в итоге имеем металлопорошковую проволоку, в состав которой легко вводятся дозированное количество раскислителей и, при необходимости, шлакообразующих компонентов. В результате экспериментальных исследований разработана металлопорошковая проволока марки ПП-АНМ1, обеспечивающая получение наплавленного металла с содержанием не более 0,35 \% легирующих добавок. Такой наплавленный металл имеет электро- и теплопроводность в $2,5 \ldots 3,0$ раза выше, чем при сварке стандартными проволоками.

Наиболее эффективным оказалось применение присадочной металлопорошковой проволоки при гелиеводуговой сварке. Данная технология успешно применена при производстве роторов крупных электрических машин.

Базовой конструкцией роторов являются два медных кольца, изготовленных из брусков меди прямоугольного сечения. Диаметр колец в зависимости от типа двигателя - 600...1000 мм. Сечения заготовок $\min 60 \times 20$ мм; max 90×70 мм. Кольца изготавливаются на вальцовочных агрегатах, а затем в зависимости от диаметра свариваются одним или двумя стыковыми швами. На рис. 2. показана форма разделки кромок стыка заготовки сечением 90×70 мм.

Гелиеводуговая сварка выполняется с применением присадочной металлопорошковой проволоки марки ПП-АНМ1, обеспечивающей минимальное снижение электропроводности в сварном соединении. Стыковое соединение приведенного на рис. 2 сечения выполняется двусторонним швом за 5..6 проходов с каждой стороны. Электропроводность металла шва при этом не ниже $60 \ldots 70$ \% электропроводности меди. Разработанная технология сварки освоена на Заводе крупных электрических машин (г. Новая Каховка).

Высокоэффективно применение данной порошковой проволоки и при ремонте медных газокислородных камер дуговых сталеплавильных печей (ДСП). Данные детали в процессе эксплу- 


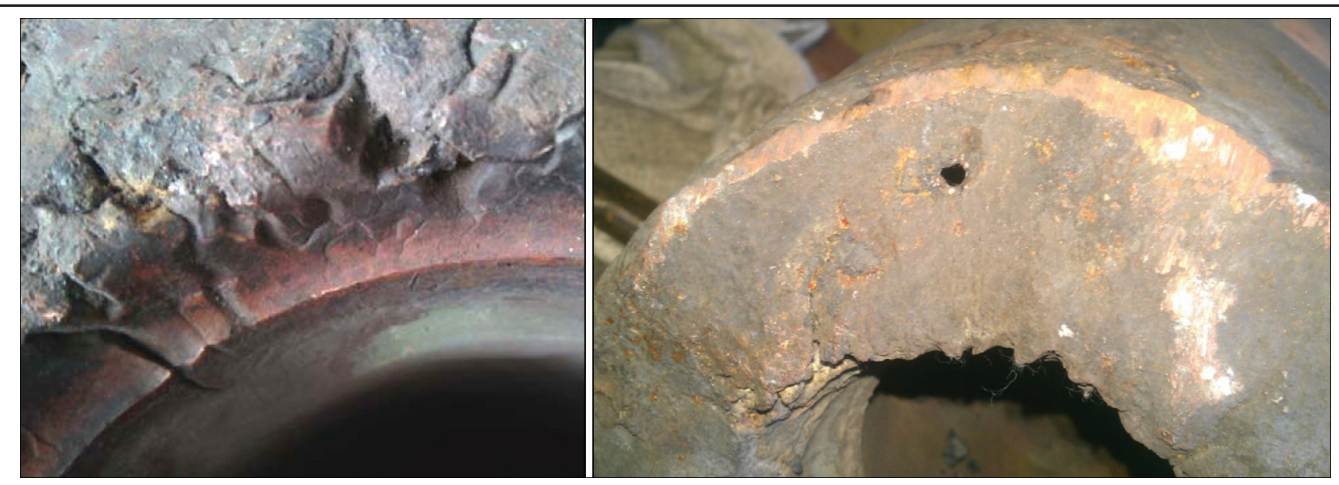

Рис. 3. Типичные дефекты медных камер после эксплуатации

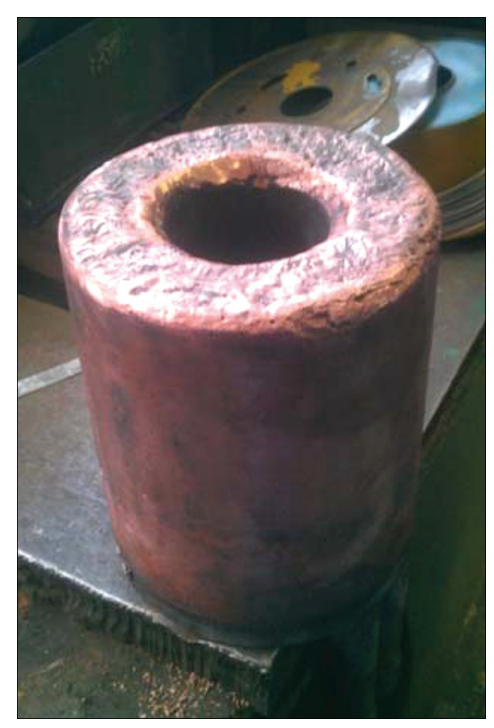

Рис. 4. Внешний вид восстановленной газокислородной камеры

атации изнашиваются в результате сверхсложных условий работы (теплового, химического и механического воздействия). На торцевой части камер образуются глубокие трещины, имеет место локальное выгорание меди вплоть до сквозных прожогов стенок водоохлаждающих каналов (рис. 3), что приводит к появлению течей. При наличии протеканий камеры выбраковываются и подлежат замене на новые. Учитывая высокую стоимость и дефицитность данных изделий (поставляемых по импорту), задача продления ресурса их эксплуатации является весьма актуальной.

Исследования по выбору рациональной технологии ремонта газокислородных камер показали, что предпочтительной для этих целей является гелиеводуговая сварка с использованием присадоч- ной металлопорошковой проволоки ПП-АНМ1. Обеспечивая получение плотного металла при многослойной наплавке, процесс позволяет восстанавливать торцевую поверхность камеры до требуемого размера по высоте. При этом толщина наплавленного слоя может составлять до 20 мм. Наличие в присадочной проволоке очень малого количества шлакообразующих добавок, как правило, не требует удаления шлака между проходами, что является существенным преимуществом по сравнению со сваркой покрытыми электродами.

На рис. 4 приведен внешний вид восстановленной камеры ДСП. Как показали производственные испытания восстановленных камер на М3 «Днепросталь», ресурс их эксплуатации возрос на $60 \ldots 80 \%$. При этом уже имеется опыт двукратного ремонта газокислородных камер.

Следует также подчеркнуть, что данная технология, обеспечивая высокую электро- и теплопроводность сварных соединений, весьма перспективна для сварки шинопроводов и электросетей различного назначения.

\section{Список литературы}

1. Илюшенко В.М., Лукьянченко Е.П. (2013) Сварка и наплавка меди и сплавов на ее основе. Киев, Международная Ассоциация «Сварка».

2. Николаев А.К., Костин С.А. (2012). Медь и жаропрочные сплавы. Энциклопедический и терминологический словарь. Фундаментальный справочник. Москва, ДПК Пресc.

\section{References}

1. Ilyushenko, V.M., Lukianchenko, E.P. (2013) Welding and surfacing of copper and alloys on its base. Kiev, IAW [in Russian].

2. Nikolaev, A.K., Kostin, S.A. (2012) Copper and heatresistant alloys. Encyclopedic and terminological dictionary: Fundamental refer. book. Moscow [in Russian].

\title{
ЕФЕКТИВНІСТЬ ВИКОРИСТАННЯ ПРИСАДНИХ МЕТАЛОПОРОШКОВИХ ДРОТІВ ПРИ ТІG-ЗВАРЮВАННІ МІДІ
}

\author{
В.М. Ілюшенко, А.М. Бондаренко, С.П. Лук’янченко, Т.Б. Майданчук
}

IE3 ім. С.О. Патона НАН України. 03150, м. Київ, вул. Казимира Малевича, 11. E-mail: office@paton.kiev.ua Описано досвід створення в IE3 ім. Є.О. Патона металопорошкових дротів для гелієводугового зварювання TIG міді і iii сплавів. Наплавлений метал дроту містить не більш 0,35 мас. \% легуючих добавок і характеризується високою елек- 
тро- та теплопровідністю. Наведено приклади ефективного застосування розробленого дроту при зварюванні роторів електромашин і ремонті газокисневих мідних камер дугових сталеплавильних печей. Бібліогр. 2, рис. 4.

Ключові слова: зварювання TIG, гелієвий захист, мідь та мідні сплави, металопорошковий дріт, електро- та теплопровідність, ефективність застосування

\title{
EFFICIENCY OF APPLICATION OF FILLER METAL-CORED WIRE IN TIG WELDING OF COPPER
}

V.M. Ilyushenko, A.N. Bondarenko, E.P. Lukyanchenko, T.B. Maydanchuk

E.O. Paton Electric Welding Institute of the NAS of Ukraine.

11 Kazimir Malevich Str., 03150, Kyiv, Ukraine. E-mail: office@paton.kiev.ua

The experience of the E.O. Paton Electric Welding Institute in creating a metal-cored wire for helium arc TIG welding of copper and its alloys was described. The deposited metal of the wire contains not more than $0.35 \mathrm{wt} . \%$ of alloying additives and is characterized by a high electrical and heat conductivity. Examples of the effective use of the developed wire in welding rotors of electric machines and in repair of gas-oxygen copper chambers are given. 2 Ref., 4 Fig.

Keywords: TIG welding, helium protection, copper and copper alloys, metal-cored wire, electrical and heat conductivity, efficiency of application

\section{LTWMP Институт электросварки им. Е.О. Патона НАН Украины \\ Национальный технический университет Украины «Киевский политехнический институт имени Игоря Сикорского» \\ Международная Ассоциация «Сварка» \\ Девятая международная конференция \\ ЛУЧЕВЫЕ ТЕХНОЛОГИИ В СВАРКЕ И ОБРАБОТКЕ МАТЕРИАЛОВ}

\author{
9 - 13 сентября 2019 г. \\ Украина, Одесса
}

\section{Председатель программного комитета академик И.В. Кривцун}

\section{Тематика конференции}

- Лазерная и электронно-лучевая сварка, резка, наплавка, термообработка, нанесение покрытий

- Электронно-лучевая плавка и рафинирование

- Гибридные процессы
- 3D-технологии

- Моделирование лучевых технологий

- Материаловедческие проблемы лазерных и электронно-лучевых технологий

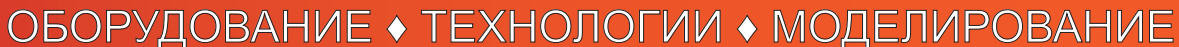

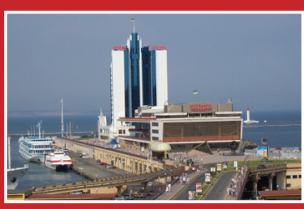

\section{АДРЕС ОРГКОМИТЕТА}

Украина, 03150, г. Киев, ул. Казимира Малевича, 11 Институт электросварки им. Е.О. Патона НАН Украины

Тел./фракс: (38044) 200-82-77, 200-81-45

E-mail: journal@paton.kiev.ua

http://pwi-scientists.com/rus/ltwmp2019

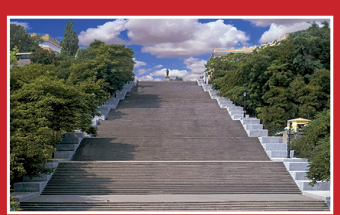




\title{
ПЛАЗМЕННО-ДУГОВАЯ ПАЙКА СТАЛИ 08КП С ПРИМЕНЕНИЕМ ПРИПОЕВ СИСТЕМЫ $\mathrm{Cu}-\mathrm{Mn}-\mathrm{Ni}-\mathrm{Si}$
}

\begin{abstract}
С.В. Максимова, И.В. Зволинский
ИЭС им. Е.О. Патона НАН Украины. 03150, г. Киев, ул. Казимира Малевича, 11. E-mail: office@paton.kiev.ua

Представлены результаты высокотемпературного дифференциального термического анализа припоев на базе системы $\mathrm{Cu}-\mathrm{Mn}-\mathrm{Ni}-\mathrm{Si}$, металлографические исследования паяных соединений стали 08кп, полученных с использованием плазменно-дугового нагрева. Показано, что при легировании системы $\mathrm{Cu}-\mathrm{Mn}-\mathrm{Ni}$ кремнием снижается температура плавления сплава и повышается его смачивающая способность. Микрорентгеноспектральным анализом определено, что паяный шов соединений стали 08кп состоит из твердого раствора на основе меди и дисперсных выделений фазы, обогащенных кремнием. На межфазной границе припой-основной металл в виде тонкой полосы (вдоль паяного шва) формируется фаза на основе железа, содержащая повышенную концентрацию кремния и марганца, что свидетельствует об образовании силицидов сложного состава. Прочность паяных соединений повышается с увеличением концентрации никеля в сплаве и составляет 367 МПа (среднее значение). Библиогр. 9, табл. 2, рис. 6.
\end{abstract}

Ключевые слова: плазменно-дуговая пайка, припой, микроструктура, растекание, температура солидуса и ликвидуса, прочность

Пайка наряду со сваркой является одним из наиболее распространенных способов получения неразъемных соединений. Важнейшее достоинство пайки - формирование паяного шва при температуре ниже температуры автономного плавления соединяемых материалов. При пайке используют различные источники нагрева, в том числе, концентрированные - дугу, плазму и др. В настоящее время технологический процесс пайки с применением плазменно-дугового нагрева используют при изготовлении различных деталей и узлов в приборостроении, автомобилестроении, в электротехнической, авиационной промышленности и др. [1-3].

В данной работе представлены результаты высокотемпературного дифференциального термического анализа и исходная структура припоев системы $\mathrm{Cu}-\mathrm{Mn}-\mathrm{Ni}-\mathrm{Si}$, показаны особенности формирования микроструктуры паяных соединений конструкционной углеродистой стали 08кп при использовании плазменно-дугового нагрева.

Экспериментальные сплавы получали методом литья на «холодной» подложке с использованием дугового нагрева. Температуры солидуса и ликвидуса определяли с использованием высокотемпературного дифференциального анализа (ВДТА) в среде гелия. Плазменно-дуговую пайку стыковых соединений листовой углеродистой стали 08кп выполняли на специальном лабораторном стенде, в качестве источника нагрева использовали установку KEMPPI MasterTIG MLS 2300 AC/DC, которая применяется для аргонодуговой сварки, и блок поджига дежурной дуги. Растекание припоев по подложке основного металла проводили в за- щитной среде аргона, а также в смеси аргона +10 \% водорода.

Из полученных паяных соединений вырезали образцы для изготовления микрошлифов и проведения металлографического и микрорентгеноспектрального анализа с помощью растрового электронного микроскопа TescanMira 3 LMU, ocнащенного энергодисперсионным спектрометром Oxford Instruments X-max $80 \mathrm{~mm}^{2}$ под управлением программного пакета INCA. Локальность измерений составляла до 1 мкм. Распределение элементов и съемку микроструктур проводили в обратно-отраженных электронах (BSE), позволяющих исследовать микрошлифы без химического травления.

В качестве базового использовали припой $\mathrm{Cu}-$ $23,5 \mathrm{Mn}-9 \mathrm{Ni}$ [4], который имеет температуру солидуса $920^{\circ} \mathrm{C}$ и ликвидуса $955^{\circ} \mathrm{C}$. Однако при исследовании растекания по углеродистой стали 08кп в условиях дугового нагрева он показал неудовлетворительный результат. С целью улучшения растекания припоя использовали легирование кремнием (1...3 мас. \%), который является универсальным депрессантом для многих припоев [5-8].

Анализ результатов высокотемпературного дифференциального термического анализа экспериментальных припоев, содержащих высокую концентрацию никеля, показал, что введение 3 мас. \% кремния снижает температуру солидуса до $903{ }^{\circ} \mathrm{C}$ и температуру ликвидуса до $949{ }^{\circ} \mathrm{C}$. Дальнейшее снижение температуры ликвидуса примерно на $56^{\circ} \mathrm{C}\left(899^{\circ} \mathrm{C}\right)$ удалось получить при более низком содержании никеля. 


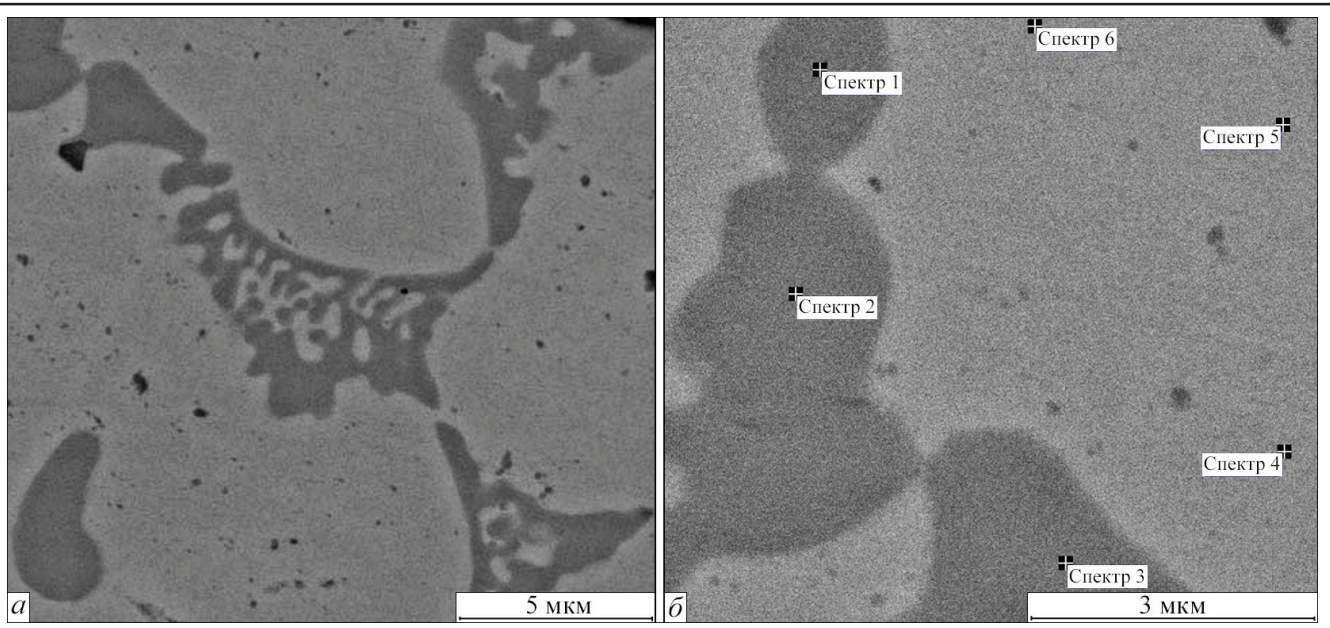

Рис. 1. Микроструктура ( $а$ ) и исследуемые участки (б) припоя системы $\mathrm{Cu}-\mathrm{Mn}-\mathrm{Ni}-3 \mathrm{Si}$ в исходном литом состоянии
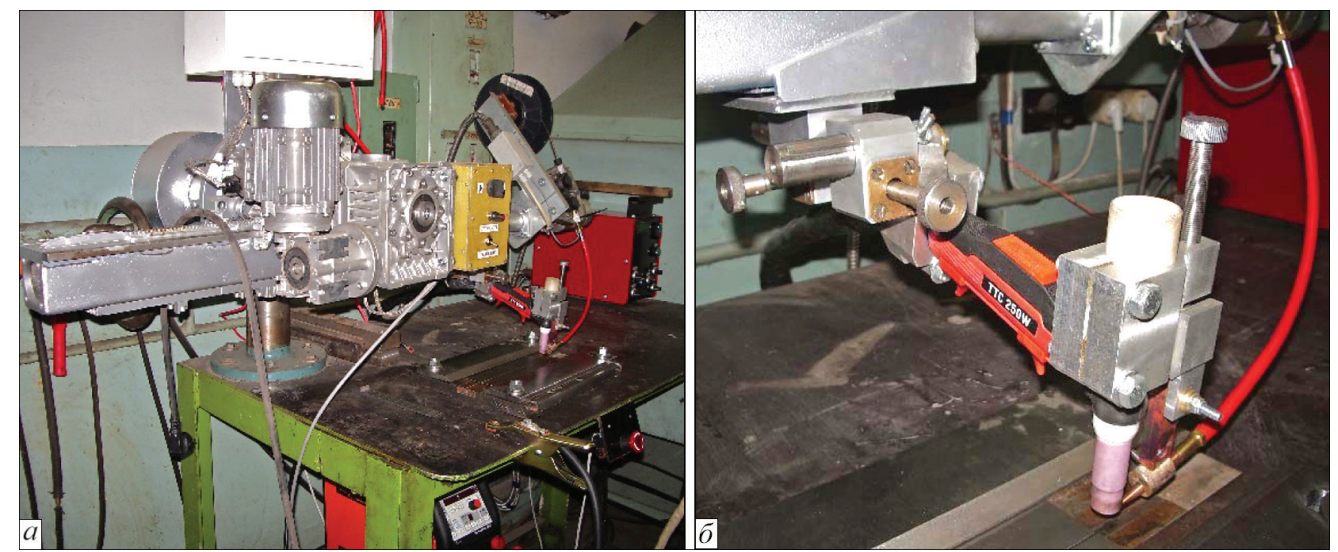

Рис. 2. Специальный стенд для плазменно-дуговой пайки (a) и узел перемещения горелки (б)

Структура припоев системы $\mathrm{Cu}-\mathrm{Mn}-\mathrm{Ni}-3 \mathrm{Si}$ двухфазная: дендриты твердого раствора, по границам которых кристаллизуется фаза, обогащенная кремнием (рис. $1, a, \sigma$, табл. 1).

Локальным микрорентгеноспектральным анализом определено дискретную концентрацию кремния в твердом растворе и показано, что она не превышает 1,95 мас. \%, в то время, как в фазе, которая выделяется по границам зерен, его концентрация повышается до 7,9 мас. \% (рис. 1, 6 , табл. 1).

При исследовании растекания припоев использовали специальный лабораторный стенд (рис. 2, $a)$, который позволяет перемещать и фиксировать горелку, а также подложку основного металла (рис. 2, б).

Припои использовали в литом виде, контролировали навеску припоя, расстояние от торца

Таблица 1. Распределение химических элементов в отдельных фазах в припое $\mathrm{Cu}-\mathrm{Mn}-\mathrm{Ni}-3 \mathrm{Si}$

\begin{tabular}{|c|c|c|c|c|}
\hline \multirow{2}{*}{$\begin{array}{c}\text { Номер } \\
\text { спектра }\end{array}$} & \multicolumn{4}{|c|}{ Химические элементы, мас. \% } \\
\cline { 2 - 5 } & $\mathrm{Si}$ & $\mathrm{Mn}$ & $\mathrm{Ni}$ & $\mathrm{Cu}$ \\
\hline 1 & 7,40 & 28,68 & 3,52 & 60,40 \\
\hline 2 & 7,90 & 30,30 & 3,36 & 58,44 \\
\hline 3 & 7,55 & 29,83 & 4,06 & 58,56 \\
\hline 4 & 1,95 & 12,61 & 0,38 & 85,06 \\
\hline 5 & 1,72 & 12,22 & 0,46 & 85,61 \\
\hline 6 & 1,91 & 12,28 & 0,59 & 85,22 \\
\hline
\end{tabular}

электрода до припоя и температуру. Термопару крепили с обратной стороны подложки. Нагрев припоя осуществляли на постоянном токе в защитной среде аргона и в смеси аргона с водородом. Проведенные эксперименты по растеканию припоя при дуговом (TIG) нагреве в среде аргона показали, что введение кремния в сплав системы $\mathrm{Cu}-\mathrm{Mn}-\mathrm{Ni}$ заметно увеличивает площадь растекания припоя. Наиболее интенсивно его влияние наблюдается при содержании $2 \ldots .3$ мас. \% крем-

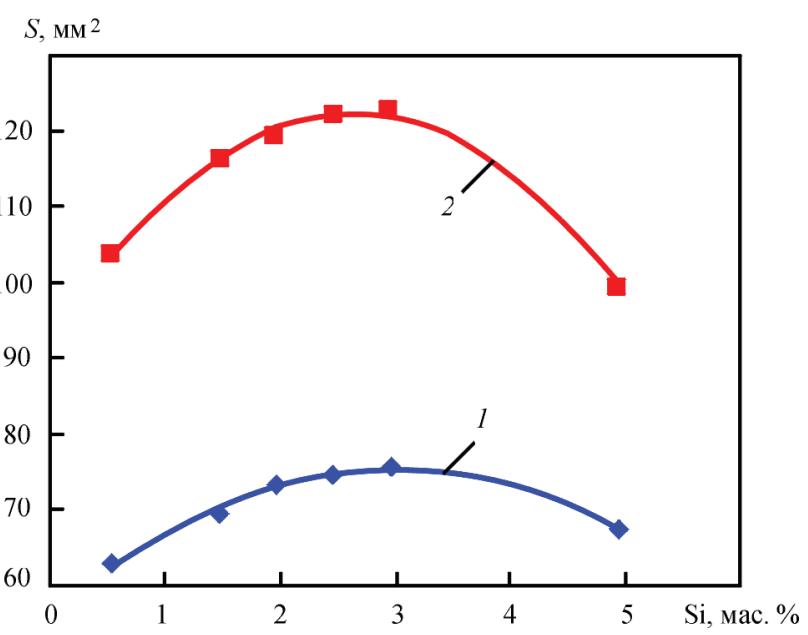

Рис. 3. Зависимость площади растекания припоя от содержания $\mathrm{Si}$ при дуговом нагреве в аргоне (1) и смеси аргона с водородом (2) 


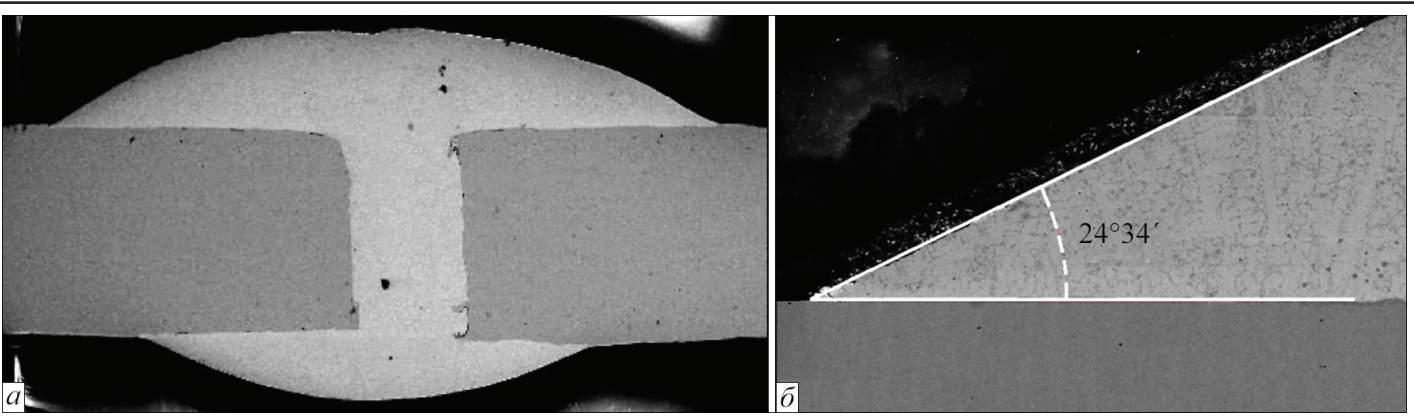

Рис. 4. Общий вид паяного соединения ( $a$ ), угол смачивания (б) углеродистой стали 08кп припоем $\mathrm{Cu}-\mathrm{Mn}-\mathrm{Ni}-3 \mathrm{Si}$ в условиях плазменно-дугового нагрева

ния (рис. 3). Дальнейшее увеличение содержания кремния до 5 мас. \% приводит к уменьшению площади растекания.

Аналогичная зависимость наблюдается при исследовании растекания припоя в защитой смеси аргона с $10 \%$ водорода, но площадь растекания существенно увеличивается (рис. 3 , кривая 2). Объяснить данную зависимость можно тем, что водород является активным восстановителем.

На базе опытных сплавов изготовлены припои в виде порошковых проволок диаметром 2,9 и 3 мм соответственно, которые использовали для проведения плазменно-дуговой пайки образцов стали 08кп (в среде аргона). Подачу припоя в виде проволоки осуществляли вручную.

В процессе отработки технологического процесса плазменно-дуговой пайки установлены оптимальные режимы $(I=50 \mathrm{~A}, U=14 \mathrm{~B})$, которые обеспечивают хорошее формирование валика припоя, смачивание основного металла и величину контактного угла $24^{\circ} 34^{\prime}$ (рис. $\left.4, a, \sigma\right)$.

Наблюдается формирование прямой и обратной галтели. Исследования микроструктуры швов паяных соединений, полученных с использованием двух припоев, не выявило значительных отличий. Большую часть шлифа занимают зерна

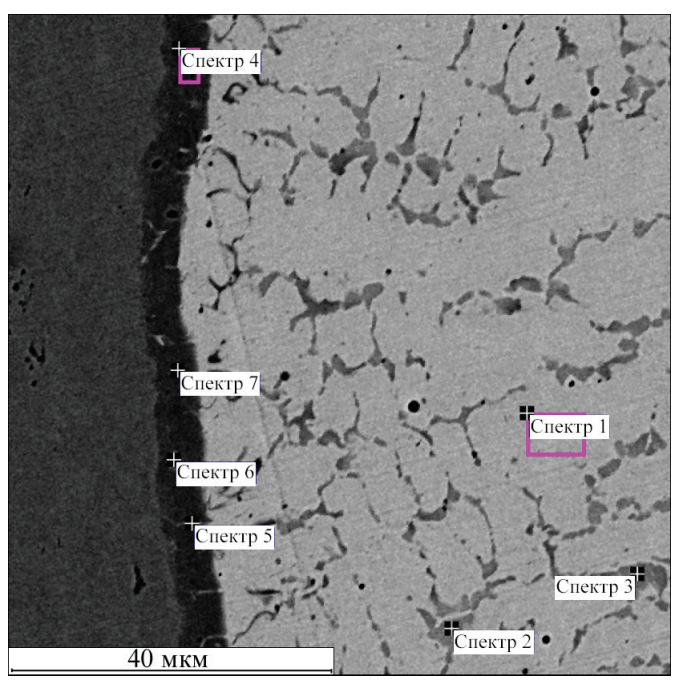

Рис. 5. Межфазная граница соединения, выполненного припоем системы $\mathrm{Cu}-\mathrm{Mn}-\mathrm{Ni}-3 \mathrm{Si}$ при использовании плазменно-дугового нагрева твердого раствора на основе меди, содержащие незначительное количество кремния (1,38 мас. \%). По границам зерен твердого раствора выделяется фаза на основе меди, обогащенная кремнием (до $7,93 \ldots 8,45$ мас. \%), что подтверждает присутствие силицидов (рис. 5, табл. 2).

В обоих случаях на межфазной границе припой - основной металл вдоль паяного шва кристаллизуется диффузионный слой на основе железа, обогащенный кремнием (до 10,23...13,08 мас. \%) и марганцем $(13,58 \ldots 15,92 \%)$, что свидетельствует о формировании силицидов железа сложного состава (рис. 4 , табл. 2) и хорошо согласуется с диаграммами состояния металлических систем. Так, в соответствии с бинарными диаграммами состояния системы железо-кремний предельная растворимость кремния в $\gamma$-железе при $1150{ }^{\circ} \mathrm{C}$ составляет 3,84 ат. \%. С понижением температуры она уменьшается, что и приводит к образованию силицидных фаз [9]. Растворимость меди в железе ограничена и тоже уменьшается со снижением температуры. Такие особенности строения диаграмм состояния металлических систем желе3о-кремний и медь-кремний способствуют тому, что при пайке на межфазной границе формируются силициды железа.

Как свидетельствуют результаты механических испытаний на разрыв стыковых плоских паяных образцов, полученных с помощью плазменно-дуговой пайки и припоя $\mathrm{Cu}-\mathrm{Mn}-\mathrm{Ni}-3 \mathrm{Si}$, разрушение происходит по шву. Наблюдается большой разброс показателей прочности от 279 до 379 МПа (рис. 6), средние значения прочности составля-

Таблица 2. Химический состав структурных составляющих паяного шва

\begin{tabular}{|c|c|c|c|c|c|}
\hline \multirow{2}{*}{ Спектр } & \multicolumn{5}{|c|}{ Химический состав, мас. \% } \\
\cline { 2 - 6 } & $\mathrm{Si}$ & $\mathrm{Mn}$ & $\mathrm{Fe}$ & $\mathrm{Ni}$ & $\mathrm{Cu}$ \\
\hline 1 & 1,38 & 13,05 & 0,64 & 0,62 & 84,31 \\
\hline 2 & 7,93 & 31,16 & 1,02 & 2,11 & 57,77 \\
\hline 3 & 8,45 & 31,44 & 1,73 & 4,76 & 53,61 \\
\hline 4 & 12,68 & 15,70 & 66,73 & 2,20 & 2,69 \\
\hline 5 & 12,20 & 15,35 & 62,80 & 2,08 & 7,57 \\
\hline 6 & 10,32 & 13,58 & 54,98 & 1,95 & 19,16 \\
\hline 7 & 13,08 & 15,92 & 67,06 & 2,15 & 1,80 \\
\hline
\end{tabular}




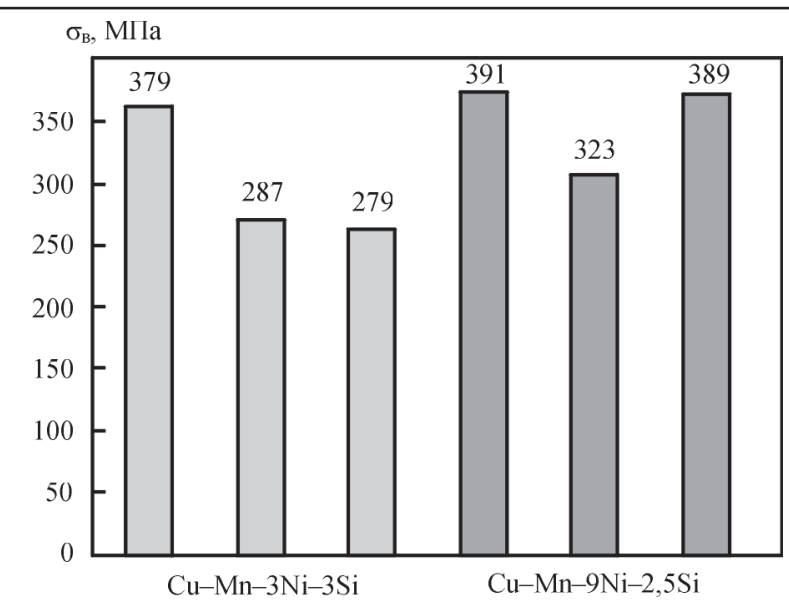

Рис. 6. Прочность на разрыв паяных стыковых образцов углеродистой стали $08 \kappa п$

ют примерно 93 \% прочности основного металла (315 МПа). Увеличение содержания никеля в припое до 9 мас. \% обеспечивает более высокие и стабильные показатели прочности (рис. 6). Образцы разрушаются по основному металлу в зоне термического влияния, средние значения прочности на разрыв повышаются до 367 МПа.

На основании полученных результатов можно сделать выбор в пользу второго припоя, который обеспечивает более высокие показатели прочности и степень стабильности данных.

\section{Выводы}

Исследованы сплавы системы $\mathrm{Cu}-\mathrm{Mn}-\mathrm{Ni}-\mathrm{Si}$ с разным содержанием никеля и кремния, определены интервалы плавления и показано, что снижение температуры ликвидуса примерно на $56^{\circ} \mathrm{C}\left(899{ }^{\circ} \mathrm{C}\right)$ обеспечивает уменьшение концентрации никеля до $3 \%$.

Установлено, что при легировании припоев системы $\mathrm{Cu}-\mathrm{Mn}-\mathrm{Ni}$ кремнием увеличивается площадь растекания. Оптимальная концентрация кремния не превышает 3 мас. \%. В структуре паяного шва преобладают дендриты твёрдого раствора на основе меди и марганца, по границам которых располагается фаза с более высокой массовой долей марганца $(31 \%)$ и кремния (около 8 \%). Вдоль межфазной границы припой-основной металл формируется силицид на основе железа, содержащий марганец и кремний, причём содержание последнего составляет $10,32 \ldots 13,08$ мас. $\%$.

Установлено, что повышение содержания никеля в припое (до 9 \%) способствует повышению показателей прочности и их стабильности. При этом разрушение происходит по основному металлу в зоне термического влияния, средние значения прочности на разрыв паяных соединений составляют 367 МПа, что находится на уровне прочности основного металла.

\section{Список литературы/References}

1. Knopp N., Killing R. (2003) Hartlöten verzinkter Feinbleche mit dem Lichtbogen - sicher und wirtschaftlich (Teil 1). Solingen. Der Praktiker, 12, 366-371.

2. Füssel U., Schetzsche V., Sziesb U., Husner J. (2002) Plasmalöten vit stromführendem Zusatzweekstoff. Der Praktiker, 10, 336-340.

3. Kallabis M., Schwankhart G. (2002) Plazmatron-Technologie im Karosserieban. Blech Rohre Profile, 4, 42-45.

4. Pugh C. (1970) Die Verwendung von Ni-Mn-Lotes fur Plattierlotungen sowie das Verfahren zum Herstellen eines solchen Lotes. FRG, Pat. 1284262.

5. Zhang Q. K., Pei Yinyin, Weimin Long (2013) Investigations on formation mechanisms of brazing cracks at the austenitic stainless steel/filler metal brazing joint interfaces. Acta Metallurgica Sinica - Chinese Edition, 49(10), 1177-1184 October 2013, DOI: 10.3724/SP.J.1037.2013.00219

6. Davis J.R. (Ed.) ASM Specialty Handbook. Copper and Copper Alloys, 276-302. DOI: 10.1361/caca P276.

7. Sejč P., Kubíček R. (2015) MIG brazing of 304L type stainless steel using $\mathrm{CuSi}_{3}$ and $\mathrm{CuSi}_{3} \mathrm{MnAl}$ brazing wire. Kovove Mater., 53, 365-375, DOI: 10.4149/km 20155365.

8. Jyrki Miettinen. Thermodynamic description of the $\mathrm{Cu}-\mathrm{Mn}-$ Ni system at the Cu-Ni side. (2003) Calphad 27(2), 147-152 June 2003, DOI: 10.1016/j.calphad.2003.08.003.

9. (1997) Лякишев Н.П. (ред.) Диаграммы состояния двойных металлических систем: Справочник: в 3 т. Т.2. Москва, Машиностроение.

(1997) State diagrams of binary metallic systems. Ed. by N.P. Lyakishev. In: Refer. book, 3 Vol., Vol. 2. Moscow, Mashinostroenie [in Russian].

\title{
ПЛАЗМОВО-ДУГОВЕ ПАЯННЯ СТАЛІ 08КП I3 ЗАСТОСУВАННЯМ ПРИПОЇВ СИСТЕМИ $\mathrm{Cu}-\mathrm{Mn}-\mathrm{Ni}-\mathrm{Si}$
}

\author{
С.В. Максимова, І.В. Зволінський
}

IE3 ім. С.О. Патона НАН України. 03150, м. Київ, вул. Казимира Малевича, 11. E-mail: office@paton.kiev.ua

\begin{abstract}
Наведено результати високотемпературного диференційного термічного аналізу припоїв на базі системи $\mathrm{Cu}-\mathrm{Mn}-\mathrm{Ni}-\mathrm{Si}$, металографічні дослідження паяних з'єднань сталі 08кп, що отримані з використанням плазмово-дугового нагріву. Показано, що при легуванні системи $\mathrm{Cu}-\mathrm{Mn}-\mathrm{Ni}$ кремнієм знижується температура плавлення сплаву і підвищується змочування основного металу. Мікрорентгеноспектральним аналізом визначено, що паяний шов з'єднань сталі 08кп складається з твердого розчину на основі міді та дисперсних виділень фази, які збагачені кремнієм. На міжфазній границі припій-основний метал у вигляді тонкої смуги (уздовж паяного шва) формується фаза на основі заліза, що містить підвищену концентрацію кремнію та марганцю, що свідчить про утворення складних силіцидів. Міцність паяних з'єднань підвищується зі збільшенням концентрації нікелю в сплаві і становить 367 МПа (середнє значення). Бібліогр. 9, табл. 2, рис. 6.
\end{abstract}

Ключові слова: плазмово-дугове паяння, припій, мікроструктура, розтікання, температура солідусу і ліквідусу, міцність 


\section{BRAZE ALLOYS OF Cu-Mn-Ni-Si SYSTEM AND PLASMA-ARC BRAZING OF 08KP(BOILING) STEEL}

\section{S.V. Maksymova, I.V. Zvolinskyy}

E.O.Paton Electric Welding Institute of the NAS of Ukraine.

11 Kazimir Malevich Str., 03150, Kyiv, Ukraine. E-mail: office@isi@nas.ua

The paper presents the results of high-temperature differential thermal analysis of braze alloys based on $\mathrm{Cu}-\mathrm{Mn}-\mathrm{Ni}$-Si system, metallographic examination of brazed joints of $08 \mathrm{kp}$ (boiling) steel, made with application of plasma-arc heating. It is shown that at silicon alloying of $\mathrm{Cu}-\mathrm{Mn}-\mathrm{Ni}$ system the alloy melting temperature decreases and its wetting ability increases. X-Ray microanalysis revealed that brazed seam of $08 \mathrm{kp}$ (boiling) steel joints consists of copper-based solid solution and dispersed precipitates of a silicon-enriched phase. An iron-based phase with higher concentration of silicon and manganese forms on braze alloy - base metal interphase as a thin band (along the brazed seam), that is indicative of appearance of silicides of a complex composition. Brazed joint strength becomes higher with increase of nickel concentration in the alloy and is equal to $367 \mathrm{MPa}$. 9 Ref., 2 Tabl., 6 Fig.

Keywords: plasma-arc brazing, braze alloy, microstructure, spreading, solidus and liquidus temperature, strength

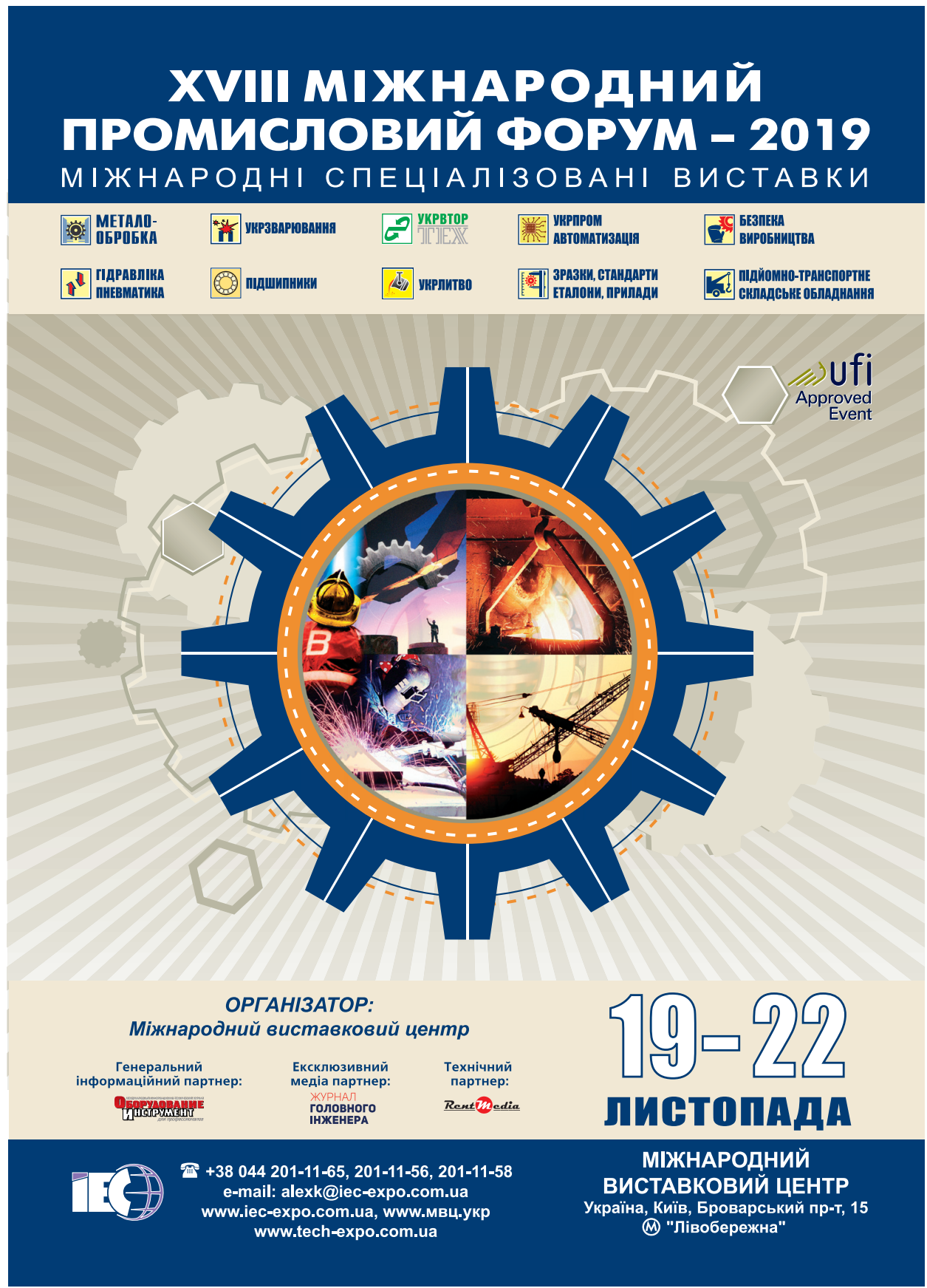




\title{
ВПЛИВ СКЛАДУ ЗВ’ЯЗУЮЧОГО ПОКРИТТЯ ЕЛЕКТРОДІВ НА ТОКСИЧНІСТЬ ЗВАРЮВАЛЬНИХ АЕРОЗОЛІВ
}

\author{
О.Г. Левченко ${ }^{1}$, А.О. Лук'яненко ${ }^{2}$, О.В. Демецька ${ }^{3}$ \\ ${ }^{1}$ Національний технічний університет України «Київський політехнічний інститут імені Ігоря Сікорського». \\ 03056, м. Київ, просп. Перемоги, 37. E-mail: levchenko.opcb@ukr.net \\ ${ }^{2}$ IE3 ім. Є.О. Патона НАН України. 03150, м. Київ, вул. Казимира Малевича, 11. E-mail: offise@paton.kiev.ua \\ ${ }^{3}$ Київський міжнародний університет. 03179, м. Київ, вул. Львівська, 49
}

\begin{abstract}
За результатами санітарно-гігієнічної оцінки покритих електродів для зварювання високолегованих хромонікелевих сталей досліджено вплив складу зв'язуючого покриття електродів на токсичність аерозолів, що утворюються при застосуванні даних електродів. Для цього застосовано експрес-метод визначення цитотоксичності, рівнів виділень та хімічного складу зварювальних аерозолів, а також їх розрахункові гігієнічні показники у відповідності 3 міжнародним стандартом ДСТУ ISO 15011-4:2008. Показано, що для створення нових марок зварювальних електродів 3 поліпшеними гігієнічними характеристиками варто мати не тільки дані первинної санітарно-гігієнічної оцінки, а й результати біологічних досліджень токсичності зварювальних аерозолів. Установлено, що застосування в покритті електродів зв'язуючого на основі чистого літієвого або літій-натрій-калієвого рідкого скла замість калій-натрієвого дає можливість зменшити рівень виділення в повітря зварювального аерозолю, вміст у ньому високотоксичного шестивалентного хрому і за рахунок цього - загальну його токсичність. Бібл. 14, табл. 3, рис. 4.
\end{abstract}

Ключові слова: покриті електроди, зварювальні аерозолі, шестивалентний хром, індекс циитотоксичності

Електродугове зварювання характеризується виділенням у повітря робочої зони шкідливих для організму людини аерозолів, токсична дія яких визначається хімічним складом зварювальних електродів [1]. Тому створення нових марок зварювальних матеріалів обов'язково має супроводжуватись їх первинною санітарно-гігієнічною оцінкою у відповідності з міжнародними стандартами ДСТУ ISO 15011-1:2008 [2] та ДСТУ ISO 15011-4:2008 [3]. Ці стандарти дозволяють отримати необхідну інформацію про хімічний склад зварювальних аерозолів (ЗА) та орієнтовно розрахувати ризик їх шкідливої дії на організм зварника. Для створення нових марок зварювальних електродів 3 поліпшеними гігієнічними характеристиками варто мати не тільки дані первинної санітарно-гігієнічної оцінки, а й результати біологічних досліджень токсичності ЗА. Такі дослідження, особливо з використанням дослідних тварин, реалізуються на протязі доволі тривалого часу й потребують значних витрат.

Для оцінювання токсичної дії малорозчинних промислових аерозолів, у тому числі зварювальних, найбільше значення має така їх ключова властивість як цитотоксичність, що визначає небезпеку виникнення професійного захворювання - пневмоконіозу [4]. Цитотоксичність як властивість частинок пилу (аерозолю) є визначальним фактором для оцінювання ступеня його дії на організм людини та математичного прогнозування порівняльної небезпеки розвитку пневмоконіозу. Цитотоксичність визначає кінетику накопичення та затримки пилу в легенях і лімфовузлах

(C) О.Г. Левченко, А.О. Лук'яненко, О.В. Демецька, 2019 людини, а також інтенсивність шкідливої дії на тканину цих органів. Цю характеристику оцінюють у різних короткочасних тестах, що пов'язано $з$ пануючими уявленнями про ключову роль пошкодження пиловими частинками макрофагів у патогенезі силікозу та інших видів пневмоконіозу. Використовуються також тести, засновані на реєстрації феноменів активації макрофагів або на тому чи іншому поєднанні цих явищ. Проте трактування результатів тестування та їх використання для прогнозування дії аерозолів на організм часто проводяться без урахування ролі процесів активації та пошкодження макрофага як у механізмах, що лежать в основі тесту, так і в патогенезі пневмоконіозу [5].

Використання так званих альтернативних токсикологічних моделей (культур клітин, експрес-тестів та ін.) дозволяє одержувати інформацію про токсичність та небезпеку хімічних сполук і матеріалів менш затратними способами чи підходами в коротші строки та більш гуманно з позицій біоетики порівняно з традиційними методами експериментальних досліджень на лабораторних тваринах in vivo. У свою чергу, інформація, отримана в експериментах in vitro, може бути використана для скринінгу зварювальних матеріалів у якості «вектора» для проведення поглиблених експериментальних досліджень in vivo. Зокрема, експрес-оцінка токсичності ЗА з використанням як тест-об'єкта короткочасної суспензійної культури сперматозоїдів бика різко знижує працемісткість і вартість випробувань. Метод дозволяє оцінити сумарний ефект від впливу на культуру всієї сукупності токсикантів, присутніх у $3 \mathrm{~A}$, за біологічною 
Таблиця 1. Показники виділень та хімічний склад 3А

\begin{tabular}{|c|c|c|c|c|c|c|c|c|}
\hline \multirow{2}{*}{$\begin{array}{c}\text { Вид рідкого скла (зв'я- } \\
\text { зуючого покриття) }\end{array}$} & \multirow{2}{*}{$\begin{array}{l}\text { Інтенсивність ви- } \\
\text { ділення } V_{\mathrm{a}}, \text { г/хв }\end{array}$} & \multirow{2}{*}{$\begin{array}{l}\text { Питоме виді- } \\
\text { лення } G_{\mathrm{a}}, \Gamma / \kappa \Gamma\end{array}$} & \multicolumn{6}{|c|}{ Масова частка, \% в 3А } \\
\hline & & & $\mathrm{Cr}^{6+}$ & $\mathrm{Cr}^{3+}$ & $\mathrm{Mn}$ & $\mathrm{Ni}$ & $F_{p}$ & $\mathrm{~F}_{\text {нр }}$ \\
\hline $\mathrm{K}-\mathrm{Na}(0 \%)$ & 0,51 & 11,58 & 1,96 & 2,62 & 4,81 & 1,47 & 11,68 & 1,30 \\
\hline $\mathrm{Li}-\mathrm{Na}-\mathrm{K}(0,7 \%)$ & 0,45 & 10,10 & 1,77 & 2,67 & 5,27 & 1,38 & 10,24 & 1,69 \\
\hline $\mathrm{Li}-\mathrm{Na}-\mathrm{K}(1,8 \%)$ & 0,35 & 7,28 & 1,44 & 2,82 & 5,69 & 1,29 & 10,35 & 1,88 \\
\hline $\mathrm{Li}-\mathrm{Na}(2,7 \%)$ & 0,26 & 5,52 & 0,89 & 3,04 & 5,73 & 1,62 & 11,65 & 1,34 \\
\hline $\operatorname{Li}(3,2 \%)$ & 0,20 & 4,52 & Не виявлено & 3,91 & 5,20 & 1,39 & 5,76 & 1,56 \\
\hline
\end{tabular}

дією іï екстракту на тест-об'єкт за час, що не перевищує 3 год [5].

У роботі [6] було підтверджено можливість застосування зазначеної методики експрес-оцінки для порівняльної гігієнічної оцінки зварювальних електродів. При цьому було підтверджено, що токсичність 3А, які утворюються під час зварювання високолегованих сталей, значно вища, ніж при зварюванні вуглецевих та низьколегованих сталей i, переважно, визначається вмістом у покритті електродів канцерогенного шестивалентного хрому $\left(\mathrm{Cr}^{6+}\right)$ та нікелю [7]. Разом з тим, як показано в роботі [8], токсичність ЗА суттєво залежить від співвідношення у складі зв'язуючого (рідкого скла) електродного покриття літію, натрію й калію $(\mathrm{Li}-\mathrm{Na}-\mathrm{K})$, що $\mathrm{i}$ визначає наявність у складі ЗА канцерогенного шестивалентного хрому $\left(\mathrm{Cr}^{6+}\right)$.

Метою даної роботи було визначення впливу хімічного складу $\mathrm{Li}-\mathrm{Na}-\mathrm{K}$ зв'язуючого покриття електродів для зварювання високолегованих хромонікелевих сталей на цитотоксичність $3 \mathrm{~A}$, що утворюються при їх застосуванні.

Відбирання проб ЗА для визначення їх санітарно-гігієнічних характеристик здійснювалось у відповідності зі стандартом [2] методом повного уловлювання аерозолю, що утворюється під час зварювання, за допомогою спеціального стенду з фільтром ФПП, встановленого на шляху руху ЗА 3 укриття зони зварювання. Визначали наступні показники утворення 3А: інтенсивність виділення

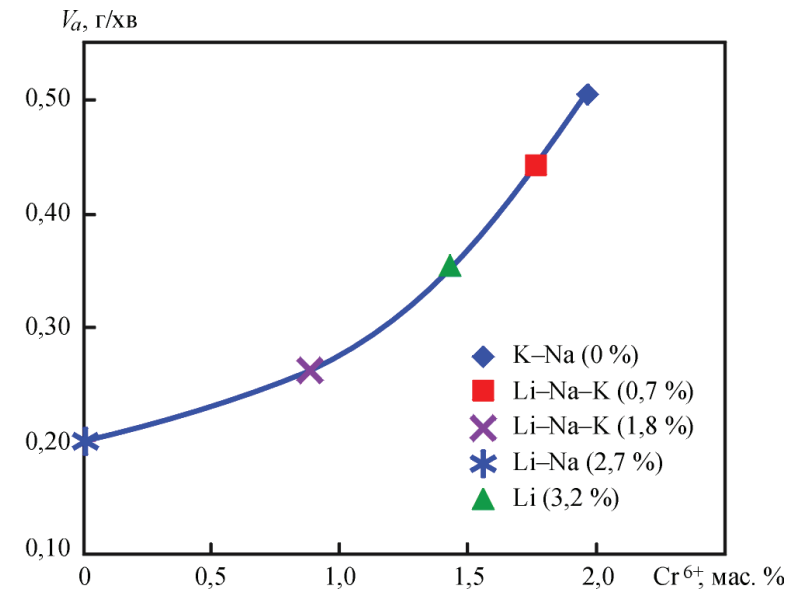

Рис. 1. Залежність інтенсивності виділення $V_{\mathrm{a}}$ ЗА від вмісту в них шестивалентного хрому $\mathrm{Cr}^{6+}$ (у скобках зазначена масова частка $\mathrm{Li}_{2} \mathrm{O}$ в рідкому склі)
$V_{\mathrm{a}}$, г/хв; питоме виділення (маса $3 \mathrm{~A}$, що утворюється при розплавленні кілограма зварювальних електродів) $G_{\mathrm{a}}, \Gamma / \kappa г$; хімічний склад 3 А, мас. \%)

Оцінювання токсичності здійснювали на підставі експериментально визначеного індексу цитотоксичності $I_{t}$ за методикою [5] експрес-оцінки токсичності 3A in vitro на серійному аналізаторі АТ-05 та (для порівняння) на основі розрахункових гігієнічних показників - граничного значення та класу ЗА згідно 3 ДСТУ ISO 15011-4:2008 [3]. Для цього користувались вище зазначеними показниками інтенсивності виділень 3А $V_{\mathrm{a}}$, мг/с та його хімічним складом у відповідності з методиками [2, 9].

Для відбирання проб ЗА використовували дослідні марки зварювальних електродів типу Э-08Х20Н9Г2Б 3 різним складом рідкого скла-зв'язуючого в покритті (табл. 1). Наплавлення здійснювали на пластини сталі 12Х18Н10Т постійним струмом (150 А) зворотної полярності з використанням випрямляча ВДУ-504. Для кожного варіанта виконували мінімум три досліди. Отримані результати досліджень (табл. 1) показують, що застосування в покритті електродів у якості зв'язуючого $\mathrm{Li}-\mathrm{Na}-\mathrm{K}$ рідкого скла замість $\mathrm{K}-\mathrm{Na}$ дозволяе (в залежності від вмісту в ньому Li) приблизно в $1,2 \ldots 1,5$ рази зменшити показники виділень ЗА і до 1,4 раза вміст у ньому високотоксичного шестивалентного хрому $\left(\mathrm{Cr}^{6+}\right)$, а застосування Li-Na зв'язуючого дає можливість у 2 рази знизити виділення 3А і у 2,2 рази вміст у ньому $\mathrm{Cr}^{6+}$ (рис. 1). Використання у покритті Li-рідкого скла дозволяє зменшити виділення $3 \mathrm{~A}$ в 2,5 рази $\mathrm{i}$ запобігти утворенню в ньому $\mathrm{Cr}^{6+}$ (рис. 2).

Відсутність у даному випадку в складі $3 \mathrm{~A} \mathrm{Cr}^{6+}$ можна пояснити хімічними властивостями рідкоземельних елементів. Відомо, що під час плавлення і утворення ЗА наявність у покритті електродів $\mathrm{K}$ i Na, як правило, призводить до утворення в результаті взаємодії цих речовин 3 хромом їх хроматів та біхроматів:

$$
\begin{gathered}
\mathrm{Cr}+\mathrm{K}_{2} \mathrm{O}, \mathrm{Na}_{2} \mathrm{O} \rightarrow \mathrm{K}_{2} \mathrm{CrO}_{4}, \mathrm{Na}_{2} \mathrm{CrO}_{4}, \\
\mathrm{Cr}+\mathrm{K}_{2} \mathrm{O}, \mathrm{Na}_{2} \mathrm{O} \rightarrow \mathrm{K}_{2} \mathrm{Cr}_{2} \mathrm{O}_{7}, \mathrm{Na}_{2} \mathrm{Cr}_{2} \mathrm{O}_{7} .
\end{gathered}
$$

Саме ці хімічні сполуки і $є$ надзвичайно небезпечними (канцерогенними) речовинами, які визначають у даному випадку величину токсичності 3А. Застосування ж у покритті електродів $\mathrm{Li}_{2} \mathrm{O}$ внаслідок особливостей його хімічних властивостей не призводить до утворювання аналогічних 


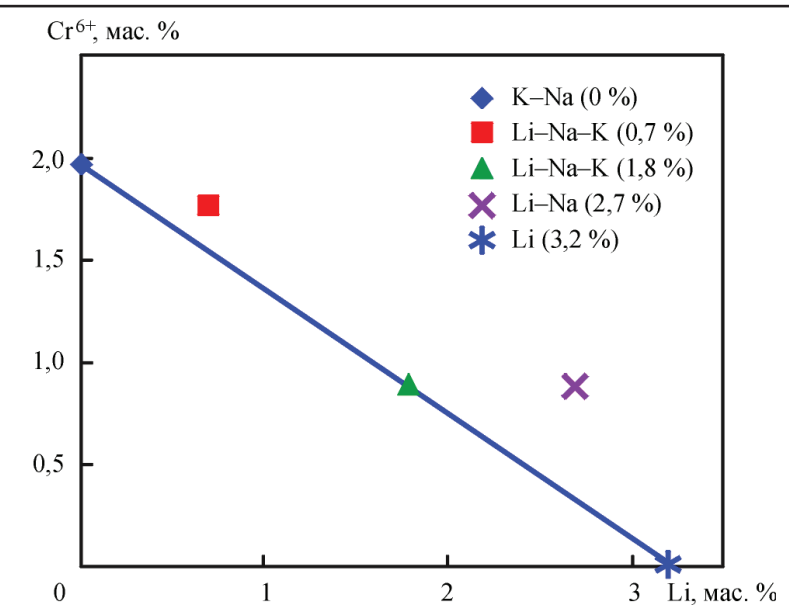

Рис. 2. Залежність шестивалентного хрому $\mathrm{Cr}^{6+}$ від вмісту літію в рідкому склі

хроматів [8, 10-12]. Утворення ж інших надзвичайно небезпечних сполук шестивалентного хрому $\mathrm{CrO}_{3}$, окрім помірно токсичного тривалентного $\mathrm{Cr}_{2} \mathrm{O}_{3}$, також не підтверджено [13]. Наступним етапом даної роботи було визначення впливу складу рідкого скла на величину токсичності 3А [14]. Для цього визначили та проаналізували розрахункові показники токсичності [3]: граничне значення $3 \mathrm{~A} L V_{\mathrm{WF}(\mathrm{A})}$ та гігієнічний клас електродів, який, в свою чергу, визначається цим граничним значенням та інтенсивністю виділення ЗА (табл. 2), а також експериментально визначений індекс цитотоксичності.

Результати досліджень (табл. 3) показали, що граничне значення $3 \mathrm{~A} L V_{\mathrm{WF}(\mathrm{A})}$ зменшується зі зростанням вмісту в покритті електродів шестивалентного хрому: воно мінімальне $\left(0,31 \mathrm{mг} / \mathrm{M}^{3}\right)$ у випадку зварювання електродами з K-Na зв'язуючим, зростає 3 підвищенням у ньому літію та має максимальну величину $\left(0,97 \mathrm{мг} / \mathrm{M}^{3}\right)$ при застосуванні в покритті рідкого скла на основі чистого літію. Мінімальне значення $L V_{\mathrm{WF}(\mathrm{A})}$ свідчить про максимальну відносну токсичність ЗА (для порівняння ЗА однієї маси) i, відповідно, максимальне - про меншу токсичність, характерну для 3А, отриманих при зварюванні електродами з покриттям із літієм. За встановленою ве-

Таблиця 3. Гігієнічна характеристика $3 \mathrm{~A}$

\begin{tabular}{|c|c|c|c|c|}
\hline $\begin{array}{c}\text { Вид рідкого } \\
\text { скла (зв'я- } \\
\text { зуючого } \\
\text { покриття) }\end{array}$ & $\begin{array}{c}\text { Інтен- } \\
\text { сивність } \\
\text { виділення } \\
3 \mathrm{~A} V_{\mathrm{a}}, \mathrm{Mг} / \mathrm{c}\end{array}$ & $\begin{array}{c}\text { Граничне } \\
\text { значення } 3 \mathrm{~A} \\
L V_{\mathrm{WF}(\mathrm{A})} \\
\text { мГ/M } \\
\end{array}$ & $\begin{array}{c}\text { Клас } \\
\text { елект- } \\
\text { родів }\end{array}$ & $\begin{array}{c}\text { Цитоток- } \\
\text { сичність } \\
I_{t}, \%\end{array}$ \\
\hline $\mathrm{K}-\mathrm{Na}(0 \%)$ & 8,3 & 0,31 & $0 \mathrm{C}$ & 22,3 \\
\hline $\begin{array}{c}\mathrm{Li}-\mathrm{Na}-\mathrm{K} \\
(0,7 \%)\end{array}$ & 7,5 & 0,33 & OB & 12,5 \\
\hline $\begin{array}{c}\mathrm{Li}-\mathrm{Na}-\mathrm{K} \\
(1,8 \%)\end{array}$ & 5,8 & 0,37 & 0B & 18,8 \\
\hline $\begin{array}{c}\mathrm{Li}-\mathrm{Na} \\
(2,7 \%) \\
\end{array}$ & 4,3 & 0,44 & OB & 29,0 \\
\hline $\operatorname{Li}(3,2 \%)$ & 3,3 & 0,97 & $1 \mathrm{~B}$ & 66,2 \\
\hline
\end{tabular}

Примітка. У скобках зазначена масова частка $\mathrm{Li}_{2} \mathrm{O}$ в рідкому склі.
Таблиця 2. Класифікація зварювальних матеріалів в залежності від рівня виділень і розрахункового граничного значення 3А [3]

\begin{tabular}{|c|c|c|c|c|c|c|}
\hline $\begin{array}{c}\text { Граничне } \\
\text { значен- } \\
\text { ня 3А }\end{array}$ & $\begin{array}{c}\text { Інтен- } \\
\text { сивність } \\
\text { виділення } \\
3 \mathrm{~A} V_{\mathrm{a}}, \text { мг/с }\end{array}$ & $<3$ & $3 \ldots 8$ & $8 \ldots 15$ & $15 \ldots 25$ & $>25$ \\
\hline $\begin{array}{c}L V_{\mathrm{WF}(\mathrm{A})} \\
\mathrm{M \Gamma} / \mathrm{M}^{3}\end{array}$ & $\begin{array}{c}\text { Клас зва- } \\
\text { рювального } \\
\text { матеріалу }\end{array}$ & A & B & $\mathrm{C}$ & D & E \\
\hline$>4,5$ & 5 & $5 a$ & $5 b$ & $5 c$ & $5 \mathrm{~d}$ & $5 e$ \\
\hline $3,5 \ldots 4,5$ & 4 & $4 a$ & $4 b$ & $4 c$ & $4 d$ & $4 \mathrm{e}$ \\
\hline $2,5 \ldots 3,5$ & 3 & $3 a$ & $3 b$ & $3 \mathrm{c}$ & $3 d$ & $3 \mathrm{e}$ \\
\hline $1,5 \ldots 2,5$ & 2 & $2 \mathrm{a}$ & $2 b$ & $2 \mathrm{c}$ & $2 d$ & $2 \mathrm{e}$ \\
\hline $0,5 \ldots 1,5$ & 1 & $1 \mathrm{a}$ & $1 b$ & $1 \mathrm{c}$ & $1 d$ & $1 \mathrm{e}$ \\
\hline$<0,5$ & 0 & $0 \mathrm{a}$ & $0 \mathrm{~b}$ & $0 \mathrm{c}$ & $0 \mathrm{~d}$ & $0 \mathrm{e}$ \\
\hline
\end{tabular}

личиною $L V_{\text {WF(A) }}$ можна зробити висновок, що токсичність 3А, отриманих при зварюванні електродами зі зв'язуючим з літієм приблизно в три рази менша, ніж ЗА, які утворюються при застосуванні $\mathrm{Na}-\mathrm{K}$ рідкого скла, що пояснюється відсутністю в ЗА шестивалентного хрому (рис. 3).

Що стосується гігієнічного класу електродів як узагальнюючого (практично абсолютного) показника токсичності, то він має нульове «0» значення для всіх електродів, крім електродів 3 літієвим зв'язуючим у покритті, який відноситься до класу 1 і свідчить про меншу токсичність ЗА. Таким чином, електроди $3 \mathrm{Na}-\mathrm{K}$ та $\mathrm{Li}-\mathrm{Na}-\mathrm{K}$ зв'язуючим відносяться до найгіршого гігієнічного класу, оскільки у складі 3А, які утворюються при зварюванні ними, присутній шестивалентний хром, а електроди з літієвим зв'язуючим відносяться до менш небезпечного класу «1».

Разом 3 тим, враховуючи показник інтенсивності виділення ЗА, уточнюємо до якого узагальнюючого класу електродів вони відносяться. Так, електроди $3 \mathrm{Na}-\mathrm{K}$ зв'язуючим покриття відносяться до найгіршого гігієнічного класу - «0С» 3 максимальною інтенсивність виділення 3А ( $\left.V_{\mathrm{a}}=8,3 \mathrm{мг} / \mathrm{c}\right)$, а електроди $з$ літієвим зв' язуючим - до найкращого в

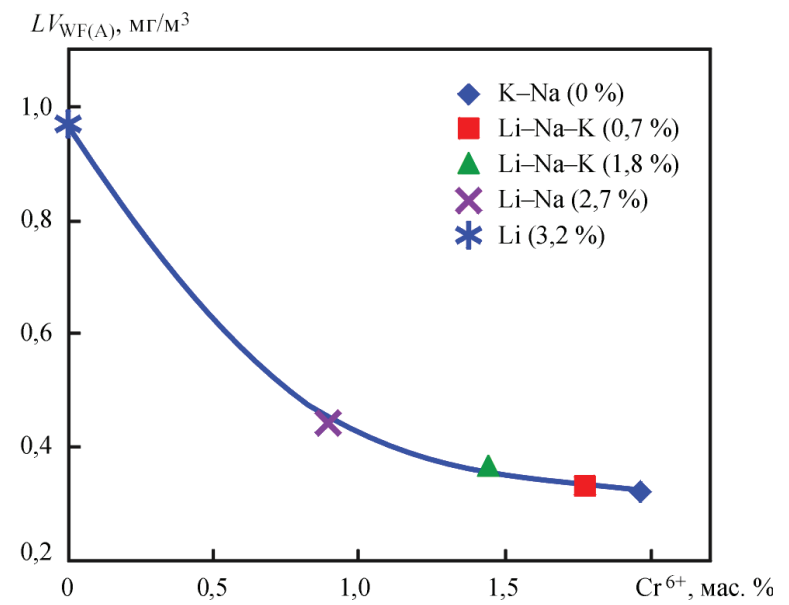

Рис. 3. Залежність граничного значення ЗА від вмісту в ньому шестивалентного хрому $\mathrm{Cr}^{6+}$ (у скобках зазначена масова частка $\mathrm{Li}_{2} \mathrm{O}$ в рідкому склі) 


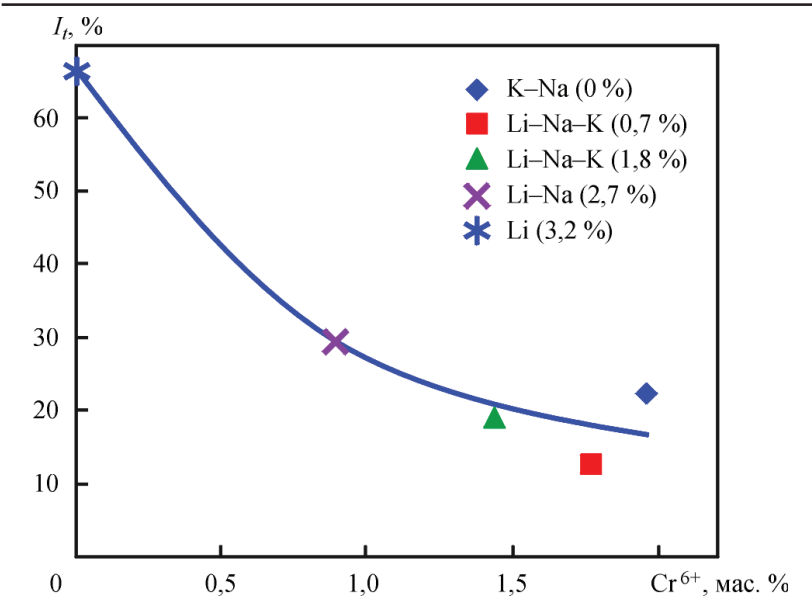

Рис. 4. Залежність індексу цитотоксичності $I_{t}$ від вмісту в $3 \mathrm{~A}$ шестивалентного хрому $\mathrm{Cr}^{6+}$ (у скобках зазначена масова частка $\mathrm{Li}_{2} \mathrm{O}$ в рідкому склі)

даному випадку класу $\left(V_{\mathrm{a}}=3,3\right.$ мг/с). При цьому слід зазначити, що практично всі електроди для зварювання високолегованих хромонікелевих сталей відносяться до класу «0», показник граничного значення $L V_{\mathrm{WF}(\mathrm{A})}$ якого не повинен перевищувати найбільш жорстке значення - $0,5 \mathrm{M \Gamma} / \mathrm{M}^{3}$ (див. табл. 2) згідно стандарту ДСТУ ISO 150114:2008 [3]. Таким чином, для зварювання високолегованих хромонікелевих сталей бажано застосовувати електроди зі зв'язуючим на основі чистого літієвого рідкого скла. Це дозволяє вийти за межі найбільш токсичного гігієнічного класу «0», тобто поліпшити гігієнічні характеристики електродів.

I нарешті, визначити числове значення токсичності ЗА дозволив показник їх цитотоксичності $I_{t}$ (див. табл. 3). Так, при застосуванні в покритті електродів літієвого зв'язуючого він має максимальну величину $\left(I_{t}=62,1 \%\right)$, що свідчить про мінімальну токсичність 3А (оскільки при значеннях $I_{t}=70 \ldots 120 \%$ дослідний матеріал вважається нетоксичним). При зварюванні електродами з іншими зв'язуючими в залежності від їх складу він змінюється від 12,5 до 29,0 \%, що свідчить про тенденцію до підвищення токсичності ЗА при зменшенні у складі рідкого скла вмісту літію. Звичайно, що це, в свою чергу, пояснюється вмістом у ЗА шестивалентного хрому: 3 підвищенням його концентрації у складі 3А зменшується індекс цитотоксичності, тобто підвищується токсичність 3А (рис. 4).

Слід зазначити, що застосування даного скринінгового методу [5] в практиці санітарно-гігієнічної оцінки зварювальних електродів не дозволяє зробити однозначний висновок про залежність токсичності 3А від вмісту в покритті $\mathrm{Li}, \mathrm{Na}, \mathrm{K}$ та шестивалентного хрому, оскільки на токсичність ЗА також впливають і інші складові покриття електродів, такі як нікель, марганець, розчинні фториди тощо.

\section{Висновок}

Використання відомих міжнародних стандартизованих методів санітарно-гігієнічної оцінки зварювальних матеріалів у комплексі з методом визначення індексу цитотоксичності зварювальних аерозолів дозволив установити, що застосування в покритті електродів для зварювання високолегованих хромонікелевих сталей зв'язуючого на основі чистого літієвого або літій-натрій-калієвого рідкого скла замість калієво-натрієвого дозволяє зменшити рівень виділення в повітря зварювального аерозолю, вміст у ньому високотоксичного шестивалентного хрому і за рахунок цього - загальну його токсичність.

\section{Список літератури}

1. Левченко О.Г. (2015) Сварочные аэрозоли и газы: процессы образования, методы нейтрализацуии и средства защичты. Киев, Наукова думка.

2. (2011) ДСТУ ISO 15011-1:2008. Охорона здоров'я та безпека у зварюванні та споріднених проиесах. Лабораторний метод відбирання аерозолів $і$ газів, утворюваних nід час дугового зварювання. Частина 1. Визначення рівня виділень і відбір проб для аналізу мікрочастинок аерозолів. Чинний від 2008-08-15. Київ, Держспоживстандарт України.

3. (2011) ДСТУ ISO 15011-4:2008. Охорона здоров'я та безпека у зварюванні та споріднених проиесах. Лабораторний метод відбирання аерозолів $i$ газів. Частина 4. Форма для запису даних про аерозолі. Чинний від 200808-15. Київ, Держспоживстандарт України.

4. Кундієв Ю.І., Корда М.М., Кашуба М.О., Демецька О.В. (2015) Токсикологія аерозолів. Тернопіль, ТДМУ «Укрмедкнига».

5. Демецька О.В., Леоненко Н.С., Мовчан В.О., Левченко О.Г., Лук'яненко А.О. (2016) Спосіб експрес-оцінки токсичності зварювальних аерозолів in vitro. Україна Пат. 110801, МПК G 01 N 33/48 (2006/01).

6. Левченко О.Г., Демецька О.В., Лук’яненко А.О. (2016) Цитотоксичність зварювальних аерозолів, що утворюються під час зварювання покритими електродами. Украӥнський журнал з проблем медицини праці, 3(48), 30-36.

7. Ющенко К.А., Булат А.В., Левченко О.Г. и др. (2009) Влияние состава основного металла и электродного покрытия на гигиенические характеристики сварочных аэрозолей. Автоматическая сварка, 7, 45-50.

8. Ющенко К.А., Булат А.В., Скорина Н.В. и др. (2017) Влияние вида связующего на технологичность изготовления и свойства покрытых электродов типа Э-08Х20Н9Г2Б. там же, 1, 5-13.

9. (1990). Методические указания по определению вредных веществ в сварочном аэрозоле (твердая фаза и газы). № 4945-88. Москва, Минздрав СССР.

10. Kimura I., Kobayashi M., Godai T. et al. (1979) Investigations on Chromium in Stainless Steel Welding Fumes. Welding Research Supplement, 8, 195-204.

11. Aström H. (1993) Advanced development techniques for coated electrodes. Welding Review International, 12, 2, 72, $74,76$.

12. Griffiths T., Stevenson A. (1989) Binder developments for stainless electrodes. Welding Review, 8, 3, 192, 194, 196.

13. Левченко О.Г., Безушко О.Н. (2015) Термодинамика образования соединений хрома в сварочных аэрозолях. Автоматическая сварка, 7, 24-27.

14. Levchenko O.G., Lukianenko A.O., Demetska O.V., Arlamov O.Y. (2018) Influence of Composition of Binder of Electrodes Coating on Cytotoxicity of Welding Aerosols. Materials Science Forum, 927, 86-92. 


\section{References}

1. Levchenko, O.G. (2015) Welding aerosols and gases: Processes of formation, methods of neutralization and security facilities. Kiev, Naukova Dumka [in Russian].

2. (2011) DSTU ISO 15011-1:2008: Occupational health and safety in welding and allied processes. Laboratory method of aerosol and gas extraction formed in arc welding. Pt 1 : Determination of emission level and sampling for analysis of aerosol microparticles. Valid from 2008-8-15. Kyiv: Derzhspozhyvstandart Ukrainy [in Ukrainian].

3. (2011) DSTU ISO 15011-1:2008: Occupational health and safety in welding and allied processes. Laboratory method of aerosol and gas extraction. Pt 4: Fume data sheets. Valid from 2008-8-15. Kyiv: Derzhspozhyvstandart Ukrainy [in Ukrainian].

4. Kundiev, Yu.I., Korda, M.M., Kashuba, M.O., Demetska O.V. (2015) Toxicology of fumes. Ternopil, TDMU Ukrmedknyga [in Ukrainian].

5. Demetska, O.V., Leonenko, N.S., Movchan, V.O. et al. (2016) Method of express-evaluation of toxicity of welding fumes in vitro. Pat. 110801, Ukraine, Int. Cl. G 01 N 33/48 (2006/01) [in Ukrainian].

6. Levchenko, O.G., Demetska, O.V., Lukyanenko, A.O. (2016) Cytotoxicity of welding fumes formed in arc welding with coated electrodes. Ukrainsky Zh. z Problem Medytsyny Pratsi, 3(48), 30-36 [in Ukrainian].

7. Yushchenko, K.A., Bulat, A.V., Levchenko, O.G. et al. (2009) Effect of composition of base metal and electrode covering on hygienic properties of welding fumes. The Paton Welding J., 7, 44-48.

8. Yushchenko, K.A., Bulat, A.V., Skorina, N.V. et al. (2017) Effect of binder type on manufacturability and properties of E-08Kh20N9G2B type coated electrodes. Ibid., 1, 2-9.

9. (1990) 4945-88: Procedural guidelines on determination of harmful substances in welding fume (solid phase and gases). Moscow, Minzdrav SSSR.

10. Kimura, I., Kobayashi, M., Godai, T. et al. (1979) Investigations on chromium in stainless steel welding fumes. Welding J., Res. Suppl., 8, 195-204.

11. Astrom, H. (1993) Advanced development techniques for coated electrodes. Welding Review. Int., 12(2), 72, 74, 76.

12. Griffiths, T., Stevenson, A. (1989) Binder developments for stainless electrodes. Welding Review, 8(3), 192, 194, 196.

13. Levchenko, O.G., Bezushko, O.N. (2015) Thermodynamics of formation of chromium compounds in welding aerosols. The Paton Welding J., 7, 22-25.

14. Levchenko, O.G., Lukianenko, A.O., Demetska, O.V., Arlamov, O.Y. (2018) Influence of composition of binder of electrodes coating on citotoxicity of welding aerosols. Mater. Sci. Forum, 927, 86-92.

\section{ВЛИЯНИЕ СОСТАВА СВЯЗУЮЩЕГО ПОКРЫТИЯ ЭЛЕКТРОДОВ НА ТОКСИЧНОСТЬ СВАРОЧНЫХ АЭРОЗОЛЕЙ}

\section{О.Г. Левченко ${ }^{1}$, А.О. Лукьяненко ${ }^{2}$, О.В. Демецкая ${ }^{3}$}

${ }^{1}$ Национальный технический университет Украины «Киевский политехнический институт имени Игоря Сикорского». 03056, г. Киев, просп. Победы, 37

${ }^{2}$ ИЭС им. Е. О. Патона НАН Украины. 03150, г. Киев, ул. Казимира Малевича, 11. E-mail: office@paton.kiev.ua

${ }^{3}$ Киевский международный университет. 03179, г. Киев, ул. Львовская, 49

По результатам санитарно-гигиенической оценки покрытых электродов для сварки высоколегированных хромоникелевых сталей исследовано влияние состава связующего покрытия электродов на токсичность аэрозолей, образующихся при применении данных электродов. Для этого применен экспресс-метод определения цитотоксичности, уровней выделений и химического состава сварочных аэрозолей, а также их расчетные гигиенические показатели в соответствии с международным стандартом ДСТУ ISO 15011-4:2008. Показано, что для создания новых марок сварочных электродов с улучшенными гигиеническими характеристиками следует иметь не только данные первичной санитарно-гигиенической оценки, но и результаты биологических исследований токсичности сварочных аэрозолей. Установлено, что применение в покрытии электродов связующего на основе чистого литиевого или литий-натрий-калиевого жидкого стекла вместо калий-натриевого дает возможность уменьшить уровень выделения в воздух сварочного аэрозоля, содержание в нем высокотоксичного шестивалентного хрома и за счет этого - общую его токсичность. Библиогр. 14, табл. 3 , рис. 4. Ключевые слова: покрытые электроды, сварочные аэрозоли, шестивалентный хром, индекс цитотоксичности

\section{INFLUENCE OF THE COMPOSITION OF ELECTRODE COATING BINDER ON TOXICITY OF WELDING FUMES}

\section{O.G. Levchenko ${ }^{1}$, A.O. Lukianenko², O.V. Demetskaya ${ }^{3}$}

${ }^{1}$ National Technical University of Ukraine «Igor Sikorsky KPI».

37 Pobedy Ave., 03056, Kyiv, Ukraine. E-mail: levchenko.opcb@ukr.net

${ }^{2}$ E.O. Paton Electric Welding Institute of the NAS of Ukraine.

11 Kazimir Malevich Str., 03150, Kyiv, Ukraine. E-mail: office@paton.kiev.ua

${ }^{3}$ Kyiv International University. 49 Lvivska Str., 03179, Kyiv, Ukraine

Results of sanitary-hygienic assessment of coated electrodes for welding high-alloyed chromium-nickel steels were used to study the influence of the composition of electrode coating binder on toxicity of aerosols, which form at application of these electrodes. Express-method of determination of cytotoxicity, levels of evolution and chemical composition of welding fumes, as well as their calculated hygienic values in accordance with international standard DSTU ISO 15011-4:2008 were applied for this purpose. It is shown that in order to develop new grades of welding electrodes with improved hygienic characteristics, it is reasonable to have not only initial sanitary-hygienic evaluation, but also the results of biological studies of the toxicity of welding fumes. It is found that application in electrode coating of a binder based on pure lithium or lithium-sodium-potassium liquid glass instead of potassium-sodium, enables reducing the level of welding fume evolution into the air, its content of highly toxic hexavalent chromium, and, lowering its general toxicity, due to that. 14 Ref., 3 Tabl., 4 Fig.

Keywords: coated electrodes, welding fumes, hexavalent chromium, cytotoxicity index 


\title{
ОЦЕНКА КРАТКОВРЕМЕННЫХ МЕХАНИЧЕСКИХ СВОЙСТВ СОЕДИНЕНИЯ ТРУДНОСВАРИВАЕМЫХ НИКЕЛЕВЫХ ЖАРОПРОЧНЫХ СПЛАВОВ ТИПА ЖС6
}

\begin{abstract}
К.А. Ющенко, А.В. Яровицын, Н.О. Червяков, А.В. Звягинцева, И.Р. Волосатов, Г.Д. Хрущов
ИЭС им. Е.О. Патона НАН Украины. 03150, г. Киев, ул. Казимира Малевича, 11. E-mail: office@paton.kiev.ua

Разработана методика оценки кратковременных механических свойств сварного соединения «основной-наплавленный металл» трудносвариваемых никелевых жаропрочных сплавов типа ЖС6 при высоких температурах, имитирующего восстановление кромок рабочих лопаток авиационных газотурбинных двигателей при их серийном ремонте. Обоснована, исходя из условия обеспечения технологической прочности такого сварного соединения, необходимость предельного уменьшения по сравнению с действующей нормативно-технической документацией размеров сварных заготовок и образцов для механических испытаний. Разработанная методика опробована на сервогидравлической машине MTS-810 при испытаниях образцов. Она позволила обосновать выбор режимов предварительной термической обработки с целью получения оптимальных прочностных свойств наплавленного металла ЖС6К. Библиогр. 19, табл. 4, рис. 7.
\end{abstract}

Ключевые слова: микроплазменная порочковая наплавка, рабочие лопатки ГТД, ремонт бандажных полок, трудносвариваемый никелевый сплав, сварное соединение, технологическая прочность, подготовка образцов, механические свойства, высокая температура

Более 10 лет микроплазменная порошковая наплавка используется для серийного ремонта деталей авиационных газотурбинных двигателей (ГТД) из трудносвариваемых никелевых жаропрочных сплавов [1-4], в частности, восстановления кромок рабочих лопаток турбины высокого давления толщиной $1,0 \ldots 3,5$ мм. Применение в условиях производства данного процесса однослойной дуговой наплавки характеризуется следующей областью энергетических параметров, где не проявляется склонность данных материалов к образованию трещин в процессе сварки плавлением и последующей термической обработки [5-7]: сила сварочного тока $2 \ldots 35$ А; эффективная тепловая мощность дуги $50 \ldots 600$ Вт; погонная энергия с учетом эффективного КПД нагрева изделия 400...2000 Дж/мм.

Кратковременные механические свойства сварного соединения «основной-наплавленный металл» при температуре эксплуатации детали авиационного ГТД, включающие значения предела текучести $\sigma_{0,2}$, предела прочности $\sigma_{\text {в }}$ и относительного удлинения $\delta$ материала, являются первичными показателями надежности разрабатываемой технологии. Принято считать, что для условий восстановления бандажных полок рабочих лопаток ТВД следует обеспечивать в диапазоне температур их эксплуатации уровень кратковременных прочностных свойств сварного соединения не менее 0,6 относительно основного металла. Важную роль 90126-85 при обеспечении данных требований, особенно в случае необходимости наплавки более чем одного слоя, играет рациональный выбор химического состава и режимов последующих термических обработок наплавленного металла.

Целью данной работы являлась разработка методики определения высокотемпературных свойств сварного соединения «основной-наплавленный металл» системы ЖС6У-ЖС6К (табл. 1) из трудносвариваемых никелевых жаропрочных сплавов применительно к задаче восстановления бандажной полки рабочей лопатки с Z-образным профилем одного из современных ГТД (рис. 1), где предварительно методами капиллярного и металлографического (рис. 2) контроля в зоне наплавки установлено отсутствие трещин.

Для выполнения поставленной цели необходимо было решить следующие задачи:

- проанализировать известные и действующие нормативно-технические документы (НТД), регламентирующие порядок подготовки образцов сварных соединений для последующего определения их кратковременных механических свойств;

Таблица 1. Химический состав (мас. \%) по основным легирующим элементам никелевых жаропрочных сплавов ЖС6У-ВИ и ЖС6К-ВИ согласно ОСТ1

\begin{tabular}{|c|c|c|c|c|c|c|}
\hline Сплав & $\mathrm{C}$ & $\mathrm{Cr}$ & $\mathrm{Ni}$ & $\mathrm{Co}$ & $\mathrm{Al}$ & $\mathrm{Ti}$ \\
\hline ЖС6У-ВИ & $0,13 \ldots 0,20$ & $8,0 \ldots 9,5$ & Основа & $9,5 \ldots 10,5$ & $5,1 \ldots 6,0$ & $2,0 \ldots 2,9$ \\
\hline ЖС6К-ВИ & $0,13 \ldots 0,20$ & $9,5 \ldots 12,0$ & $-"-$ & $4,0 \ldots 5,5$ & $5,0 \ldots 6,0$ & $2,5 \ldots 3,2$ \\
\hline
\end{tabular}

Окончание табл. 1.

\begin{tabular}{|c|c|c|c|c|c|c|c|}
\hline Сплав & Mo & $\mathrm{W}$ & $\mathrm{Nb}$ & $\mathrm{Fe}$ & $\mathrm{Mn}$ & $\mathrm{Si}$ & $\mathrm{B}$ \\
\hline ЖС6У-ВИ & $1,2 \ldots 1,4$ & $9,5 \ldots 11,0$ & $0,8 \ldots 1,2$ & $<1,0$ & $<0,4$ & $<0,4$ & $<0,035$ \\
\hline ЖС6К-ВИ & $3,5 \ldots 4,8$ & $4,5 \ldots 5,5$ & $1,4 \ldots 1,8$ & $<2,0$ & $<0,4$ & $<0,4$ & $<0,02$ \\
\hline
\end{tabular}



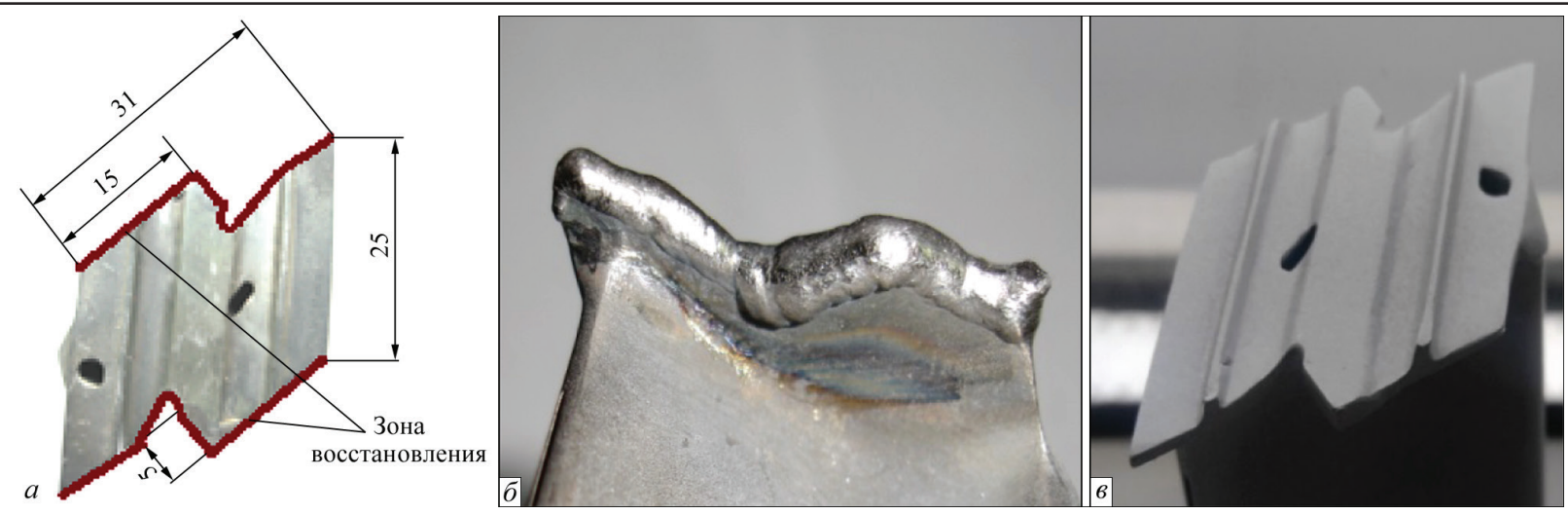

Рис. 1. Внешний вид опытной рабочей лопатки турбины из никелевого жаропрочного сплава ЖС6У, восстановленной микроплазменной порошковой наплавкой сплава ЖС6К: $a$ - характеристики зоны ремонта; $\sigma$ - внешний вид наплавленной бандажной полки с Z-образным профилем; в - внешний вид восстановленной бандажной полки после механической обработки и капиллярного контроля

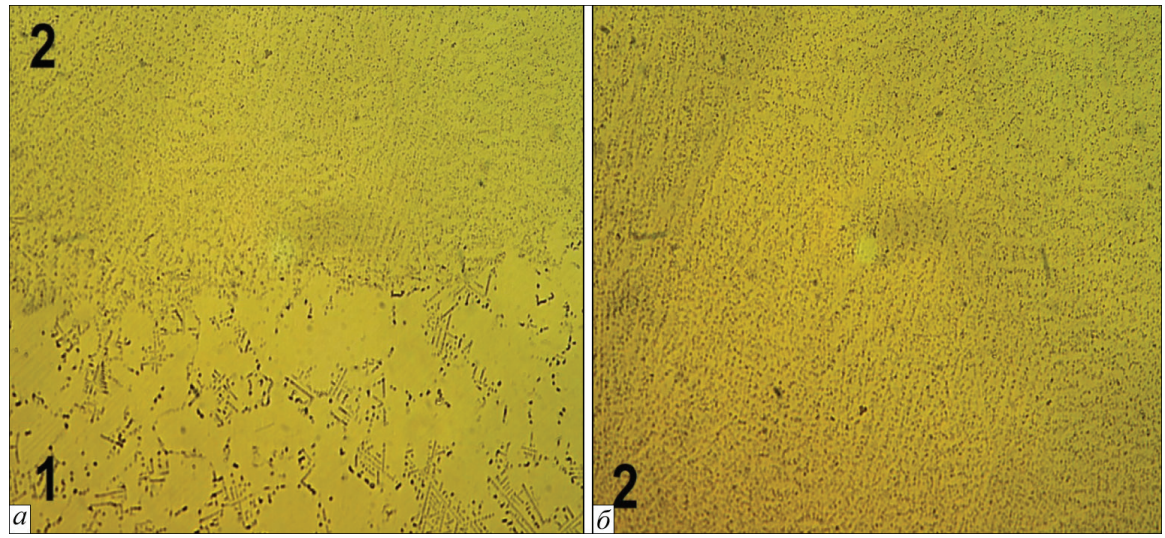

Рис. 2. Микроструктура (×100) соединения «основной (1) - наплавленный (2) металл» восстановленной бандажной полки (система ЖС6У-ЖС6К): $a$ - линия сплавления; $\sigma$ - наплавленный металл ЖС6К

- аргументировать выбор формы и размеров образца для испытаний на статическое растяжение при температуре $1000{ }^{\circ} \mathrm{C}$ и, соответственно, исходной сварной заготовки;

- при температуре испытаний $1000^{\circ} \mathrm{C}$ исследовать закономерности изменения показателей кратковременных механических свойств типовых зон сварного соединения «основной-наплавленный металл» системы ЖС6У-ЖС6К при различных режимах их термической обработки.

Установлено, что новые национальные гармонизированные [9-12] и международный [13] стандарты при оценке кратковременных свойств сварных соединений при повышенных температурах предполагают использование:

- для наплавленного металла шва при продольном растяжении цилиндрических образцов с диаметром рабочей части 8 и более мм; габаритным диаметром их захватной части 12 и более мм и общей длиной образца более 77 мм;

- для сварных соединений при их поперечном растяжении кроме указанных выше цилиндрических образцов - плоские образцы толщиной от 3,0 до 8,3 мм с шириной захватной части 35 мм и общей длиной образца $190 \ldots 215$ мм.
Ранее действовавший в нашей стране ГОСТ 6996 [8] (до 01.01.2019) для оценки кратковременных механических свойств наплавленного металла по сравнению с новыми национальными гармонизированными стандартами [9-12] дополнительно предполагал использование цилиндрических образцов с диаметром рабочей части 3 и 6 мм; габаритным диаметром их захватной части 6 и 12 мм и общей длиной образцов $30 \ldots 86$ мм.

Также в проанализированных НТД [9-13] для оценки кратковременных механических свойств наплавленного металла требуется использовать сварные заготовки значительной толщины: стыковые швы с толщиной основного металла 12 мм [9, 10]; с общей шириной и высотой валика соответственно 20 и более 30 мм [8].

Адекватность требований, перечисленных выше в НТД [8-13], применительно к наплавленному металлу трудносвариваемого никелевого жаропрочного сплава ЖС6К, проверялась на серии технологических проб ввиду наличия для сварных соединений никелевых жаропрочных сплавов с высоким содержанием упрочняющей $\gamma^{\prime}$-фазы ограничений по уровню тепловложений в изделие и объему наплавленного метала $[7,14,15]$. Проверка технологических проб на наличие трещин 


\section{ПРОИЗВОДСТВЕННЫЙ РАЗДЕЛ}

Таблица 2. Особенности обеспечения технологической прочности в сварных соединениях с участием наплавленного металла трудносвариваемого никелевого жаропрочного сплава ЖС6К

\begin{tabular}{|c|c|c|c|c|c|c|c|c|c|}
\hline \multirow{2}{*}{$\begin{array}{l}\text { Номер } \\
\text { пробы }\end{array}$} & \multirow{2}{*}{$\begin{array}{c}\text { Тип } \\
\text { наплавки/ } \\
\text { сварки }\end{array}$} & \multirow{2}{*}{$\delta, \mathrm{MM}$} & \multirow{2}{*}{ Тип ОМ } & \multirow{2}{*}{$B, \mathrm{MM}$} & \multirow{2}{*}{$H$, мм } & \multirow{2}{*}{$L, \mathrm{MM}$} & \multirow{2}{*}{$V_{\mathrm{H}}, \mathrm{cm}^{3}$} & \multicolumn{2}{|c|}{$\begin{array}{c}\text { Обеспечение технологической } \\
\text { прочности в процессе }\end{array}$} \\
\hline & & & & & & & & $\begin{array}{c}\text { наплавки/ } \\
\text { сварки }\end{array}$ & $\begin{array}{c}\text { последующей } \\
\text { т/o }\end{array}$ \\
\hline 1 & УП & 2,0 & ЖС6У & $3 \ldots 5$ & 5 & $40 \ldots 45$ & $0,60 \ldots 1,13$ & + & + \\
\hline 2 & УП & $2,5 \ldots 3,0$ & ЖС6У & $4 \ldots 6$ & $12 \ldots 15$ & $40 \ldots 45$ & $1,92 \ldots 4,50$ & + & + \\
\hline 3 & УП & 5,0 & ЖС6У & $7 \ldots 8$ & $5 \ldots 7$ & 50 & $1,75 \ldots 2,80$ & + & + \\
\hline 4 & УП & $1,8 \ldots 2,5$ & ЖС6У, ЖС6К & $4 \ldots 6$ & $10 \ldots 14$ & $140 \ldots 210$ & $5,60 \ldots 17,60$ & - & - \\
\hline 5 & УП & $2,0-3,0$ & $\begin{array}{l}\text { Ауст. нерж. } \\
\text { сталь }\end{array}$ & $5 \ldots 7$ & $25 \ldots 30$ & $50 \ldots 70$ & $6,25 \ldots 14,70$ & + & + \\
\hline 6 & УП & $2,0-3,0$ & $\begin{array}{l}\text { Ауст. нерж. } \\
\text { сталь }\end{array}$ & $5 \ldots 7$ & $35 \ldots 40$ & $50 \ldots 70$ & $8,75 \ldots 19,6$ & + & - \\
\hline 7 & Пл & 2,0 & ЖС6К & $5 \ldots 7$ & $2 \ldots 3$ & $50 \ldots 70$ & $0,50 \ldots 1,47$ & - & - \\
\hline 8 & Ш & $1,5-2,0$ & ЖСЗДК & $5 \ldots 7$ & $2 \ldots 3$ & $50 \ldots 70$ & $0,40 \ldots 1,31$ & - & - \\
\hline \multicolumn{10}{|c|}{ Ожидаемые результаты } \\
\hline 9 & УП & $12-20$ & $\begin{array}{l}\text { ЖС6, ауст. } \\
\text { нерж. сталь }\end{array}$ & $14 \ldots 20$ & $\geq 30$ & $\geq 80$ & $\geq 3,6$ & - & - \\
\hline 10 & Ш & $12-16$ & ЖС6У & $12 \ldots 16$ & $2 \ldots 3$ & $\geq 150$ & $\geq 26,8$ & - & - \\
\hline
\end{tabular}

в основном и наплавленном металле осуществлялась как визуально (при увеличении до ×10), так и капиллярным контролем. Полученные и ожидаемые результаты такой проверки представлены в табл. 2, схема наплавки технологической пробы на узкой подложке и пример ее внешнего вида в виде наплавки на узкую подложку - на рис. 3.

Установлено, что после превышения некоторого объема наплавленного валика из трудносвариваемого жаропрочного сплава ЖС6К (в первую очередь характеризующегося высотой $H$ более 35 мм при длине наплавленного валика $L=50 \ldots 70$ мм и $H>5$ мм при $L \geq 140$ мм) в нем возникают трещины повторного нагрева. Соответственно, ввиду наличия трещин валик наплавленного металла ЖС6К такого объема не может иметь приемлемого уровня механических свойств, в том числе при высоких температурах. Схожая ситуация возможна в случае выполнения сварных швов или наплавки на пластину.

В то же время показано, что при ограничении длины наплавленного валика менее 50..70 мм возможна многослойная наплавка сплава ЖС6К без нарушения технологической прочности соответствующего сварного соединения в следующих случаях:

- при толщине основного металла ЖС6У $\delta=$ $=2,5 \ldots 3,0$ мм на высоту не менее 12 мм;

- при толщине основного металла ЖС6У $\delta=$ = 5,0 мм на высоту не менее 5 мм;

- при толщине основного металла из аустенитной нержавеющей стали на высоту до 30 мм.

Установленная область обеспечения технологической прочности в сварном соединении «ос- новной-наплавленный металл» с участием наплавленного металла ЖС6К по объему наплавки в 2,5 ..13 раз превышает необходимый объем наплавленного металла на реальном изделии - paбочей лопатке турбины авиационного ГТД.

Исходя из изложенного выше можно сделать следующие выводы. Реализация требований НТД [9-12] применительно к испытаниям на статиче-
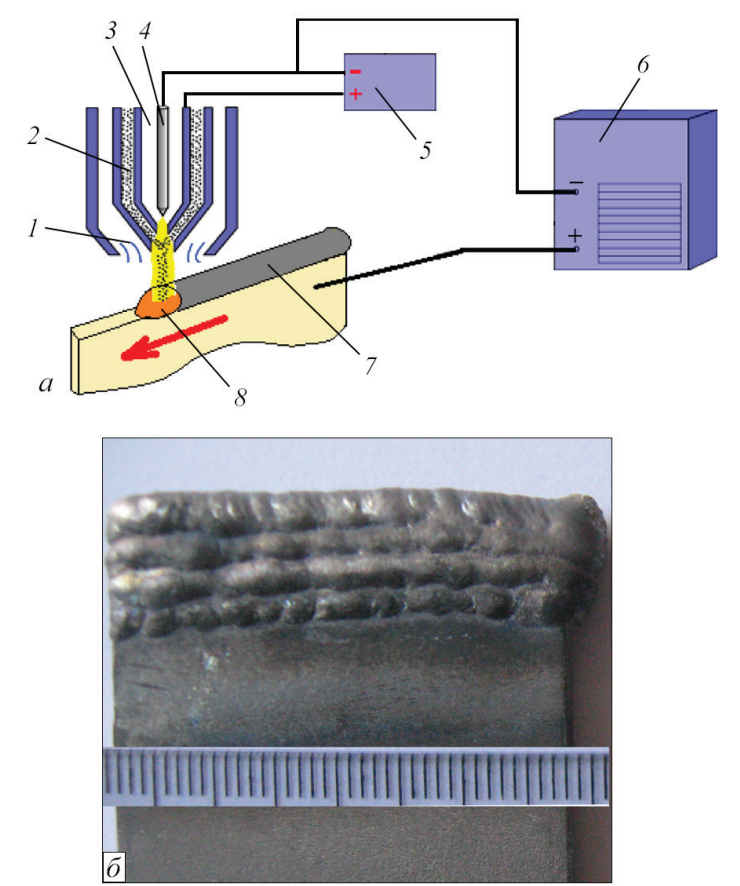

Рис. 3. Схема микроплазменной порошковой наплавки на узкую подложку $(a)$ и внешний вид соответствующей технологической пробы при многослойной наплавке (б) (1защитный газ; 2 - транспортирующий газ и порошок; 3 — плазмообразующий газ; 4 - W-электрод; 5 - источник питания дежурной дуги; 6 - источник питания микроплазменной дуги; 7 - наплавленный валик; 8 - сварочная ванна 
ское растяжение при температуре $1000{ }^{\circ} \mathrm{C}$ соединений с участием трудносвариваемого никелевого жаропрочного сплава ЖС6К может привести к неоправданному повышению технических требований к мощности разрывной машины; размеров специализированных захватов для высокотемпературных испытаний; расхода дорогостоящего материала никелевого жаропрочного сплава на сварные заготовки; трудоемкости непосредственного изготовления образцов для механической обработки. Однако главной причиной нерациональности требований НТД [9-12] является то, что воспроизведение процесса подготовки и выполнения стыкового сварного соединения трудносвариваемого никелевого жаропрочного сплава типа ЖС6 толщиной $12 \ldots 16$ мм приведет к значительному увеличению необходимой мощности микроплазменной дуги и многократному увеличению уровня действующих растягивающих напряжений и деформаций в процессе прохождения сварочного термодеформационного цикла. По предварительным оценкам потребуется увеличение силы сварочного тока не менее чем в 5...10 раз по сравнению с реальным режимом восстановительной наплавки рассматриваемой лопатки, что, в большинстве случаев, ведет к нарушению теплового режима работы применяемого плазмотрона и требует, как минимум, разработки его новой модели для увеличенной мощности микроплазменной дуги. В то же время в данных условиях с высокой вероятностью прогнозируется нарушение технологической прочности такого соединения с образованием в его зоне трещин в процессе сварки плавлением или последующей термической обработки.

Таким образом, основные положения разрабатываемой методики оценки кратковременных механических свойств при высоких температурах $\left(1000{ }^{\circ} \mathrm{C}\right)$ для соединения «основной-наплавленный металл» трудносвариваемого никелевого жаропрочного сплава с высоким содержанием $\gamma^{\prime}$-фазы можно сформулировать следующим образом.

1. Геометрические размеры исходной сварной заготовки и область значений энергетических показателей режимов для ее подготовки должны соответствовать возможности выполнения в соответствующем соединении условия обеспечения технологической прочности (отсутствуют трещины) в процессе сварки плавлением и последующей термической обработки.

2. Область значений энергетических показателей режимов для подготовки сварной заготовки, характеризующих мощность микроплазменной дуги и суммарные погонные тепловложения в изделие, должна быть максимально близка к реальным режимам наплавки и, соответственно, значениям показателей тепловложений в изделие планируемой технологии восстановления кромки рабочей лопатки авиационного ГТД.

3. Геометрические размеры и форма образца для механических испытаний выбираются таким образом, чтобы из исходной сварной заготовки определенных предельных размеров, где не проявляется склонность трудносвариваемого никелевого жаропрочного сплава к образованию трещин, можно было изготовить один или несколько таких образцов.

4. Геометрические размеры и форма отдельного образца для механических испытаний выбираются таким образом, чтобы обеспечивались минимальный расход дорогостоящего материала, техническая возможность и приемлемая трудоемкость его изготовления; рационально использовалась мощность испытательной машины и выполнялись условия длительного ресурса работы захватов испытательной машины.

Для обеспечения изложенных выше требований предложен плоский образец с оптимизированным сечением рабочей части (рис. 4, a), изготавливаемый электроэррозионной резкой. С целью уменьшения габаритов захватной части образца введена система промежуточных переходников к захватам (рис. 4, б) испытательной сервогидравлической машины MTS-810 (максимальное усилие разрыва 3 т). Новый образец, в отличие от регламентированных в НТД [8-12], позволил устранить критическое превышение толщины и
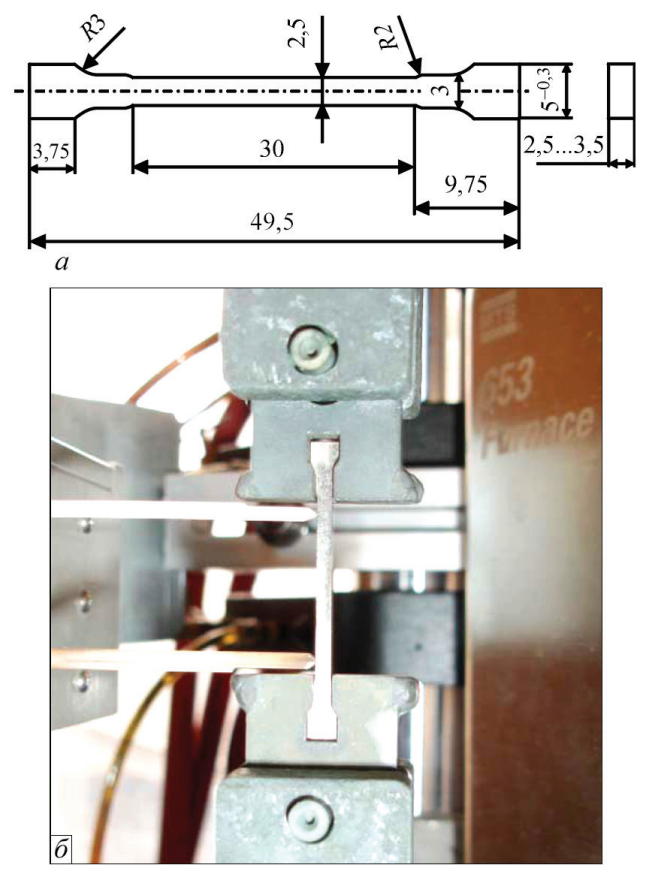

Рис. 4. Форма и размеры плоского пропорционального образца для оценки кратковременных механических свойств трудносвариваемого наплавленного металла ЖС6К при высоких температурах ( $a$ ) и внешний вид специализированных переходников к захватам испытательной сервогидравлической машины MTS-810 (б) 
Таблица 3. Сравнение выполнения базовых требований для образца согласно рис. 4 к его форме и размерам в международной [13] и отечественной НТД $[16,17]$

\begin{tabular}{|c|c|c|c|c|c|}
\hline ГОСТ 1497-84 [16] & $\begin{array}{c}\text { Выпол- } \\
\text { нение } \\
\text { условий }\end{array}$ & ДСТУ ЕN 10002-1:2006 [17] & $\begin{array}{c}\text { Выпол- } \\
\text { нение } \\
\text { условий }\end{array}$ & ISO 6892-1:2016(E) [13] & $\begin{array}{c}\text { Выпол- } \\
\text { нение } \\
\text { условий }\end{array}$ \\
\hline $\begin{array}{c}\text { Требования к начальной } \\
\text { расчетной длине рабочей } \\
\text { части образца } \\
l_{0}=11,3 \cdot \sqrt{F_{0}} \approx 30 \text { мм (п.1.8) }\end{array}$ & + & $\begin{array}{c}\text { Требования к начальной } \\
\text { расчетной длине рабочей } \\
\text { части образца } \\
\left.L_{0}=11,3 \cdot \sqrt{ } S_{0} \approx 30 \text { мм (п. } 6.1\right)\end{array}$ & + & $\begin{array}{c}\text { Требования к начальной } \\
\text { расчетной длине рабочей } \\
\text { части образца } \\
L_{0}=11,3 \cdot \sqrt{ } S_{0} \approx 30 \text { мм (п. 6.1) }\end{array}$ & + \\
\hline 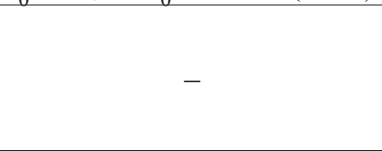 & - & $\begin{array}{c}\text { Требования к минимальной } \\
\text { начальной расчетной длине } \\
\text { рабочей части образца } \\
L_{0}>20 \text { мм (п. 6.1) }\end{array}$ & + & $\begin{array}{c}\text { Требования к минимальной } \\
\text { начальной расчетной длине } \\
\text { рабочей части образца } \\
\left.L_{0}>15 \text { мм (п. } 6.1\right)\end{array}$ & + \\
\hline- & - & $0_{0}$ & + & $\begin{array}{l}\text { Требования к размерам базо- } \\
\text { вого участка под установку } \\
\text { экстензометра } \\
0,9 L_{0}>L_{e}>0,5 L_{0} ; L_{e}=25 \text { мм } \\
\text { (п. 8.3) }\end{array}$ & + \\
\hline $\begin{array}{l}\text { Требования к общей длине } \\
\text { рабочей части образца } \\
\begin{array}{c}l=l_{0}+(1,5 \ldots 2,5) \sqrt{F_{0}}= \\
=30+(4,11 \ldots 6,84) \approx \\
\quad \approx 34 \ldots 41(\text { п.1.12) }\end{array}\end{array}$ & + & $\begin{array}{c}\text { Требования к общей длине } \\
\text { рабочей части образца } \\
L=L_{0}+(1,5) \cdot \sqrt{ } S_{0}=30+ \\
+(4,11 \ldots 6,84) \approx 34 \ldots 37 \\
\text { (Дополнение Д } 2.1)\end{array}$ & + & $\begin{array}{c}\text { Требования к общей длине } \\
\text { рабочей части образца } \\
L=L_{0}+(1,5) \cdot \sqrt{ } S_{0}=30+ \\
+(4,11 \ldots 6,84) \approx 34 \ldots .37 \\
\text { (Приложение D } 2.1)\end{array}$ & + \\
\hline
\end{tabular}

длины, присущее соответственно цилиндрическим и плоским образцам. Таким образом, объем наплавленного металла был приведен в соответствие к предварительно установленным на технологических пробах требованиям обеспечения технологической прочности для сварного соединения «основной-наплавленный металл» с участием никелевого жаропрочного сплава ЖС6К. Таблица 3 содержит обобщенный анализ соответствия формы и размеров предложенного на рис. 4 образца базовым требованиям к плоским пропорциональным образцам в НТД $[13,16,17]$. Расчетная оценка суммарного количества погонных тепловложений в изделие для сварной заготовки нового образца по сравнению с цилиндрическими образцами (рис. 5) согласно НТД [13], демонстрирует их снижение ориентировочно в 7...10 раз. По сравнению со стыковым сварным швом ожидаемый эффект снижения суммарных погонных тепловложений при подготовке сварной заготовки нового образца составляет приблизительно 11..15 раз.

Кратковременные механические свойства соединения «основной-наплавленный металл» трудносвариваемого никелевого жаропрочного сплава, имитирующего восстановление кромки лопатки, предлагается оценивать путем испытаний на статическое растяжение двух типов образцов: 50 \% основного $+50 \%$ наплавленного металла, имитирующих район линии сплавления; 100 \% наплавленного металла. Внешний вид исходных сварных заготовок системы ЖС6У6(ОМ)-ЖС6К(НМ) и ЖС6К(НМ), для которых обеспечивается технологическая прочность соответствующих соединений в процессе многослойной наплавки и последующих термических обработок, со схемой вырезки образцов для высокотемпературных механических испытаний представлен на рис. 6.

Испытания образцов на статическое растяжение при температуре $1000{ }^{\circ} \mathrm{C}$ проводили на сервогидравлической машине MTS-810 (рис. 7) при различных режимах предварительной термической обработки: $1050{ }^{\circ} \mathrm{C}-2,5$ ч [2]; гомогенизация при температуре $1220{ }^{\circ} \mathrm{C}$ (согласно ОСТ1 90126-85) длительностью 2 и 4 ч; гомогенизация при температуре $1220{ }^{\circ} \mathrm{C}$ (согласно ОСТ1 90126$85)$ длительностью 4 ч и последующее старение при температуре $950{ }^{\circ} \mathrm{C}$ длительностью 4 ч [18]. В табл. 4 приведены усредненные на основе двух испытаний значения показателей крат-

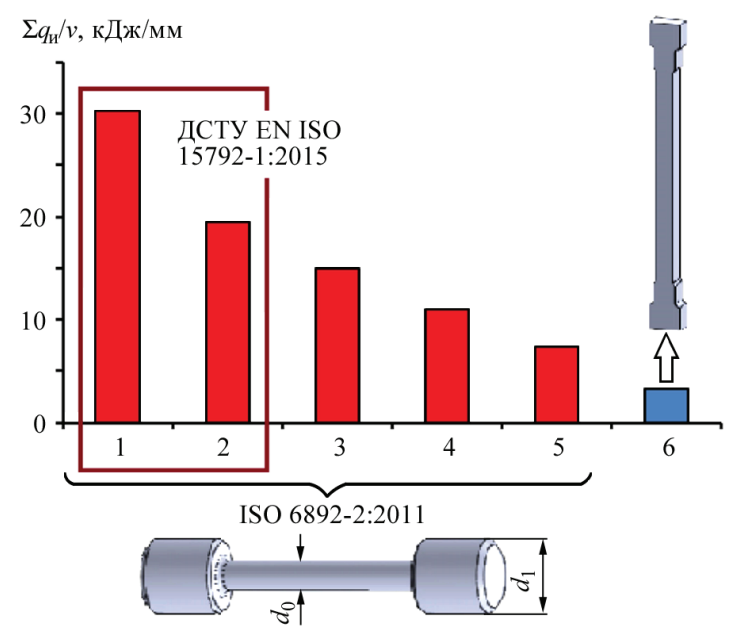

Рис. 5. Расчетная оценка суммарного количества погонных тепловложений в изделие при получении заготовок образцов способом многослойной наплавки сплава ЖС6К на торец пластины для ряда цилиндрических образцов согласно НТД ISO 6892-2:2011 [13] (№ 1-№ 5) и нового плоского пропорционального образца (№ 6) $\left(1-d_{0}=10 \mathrm{мм}, d_{1}=\mathrm{M} 16 ; 2-d_{0}=\right.$ $=8 \mathrm{MM}, d_{1}=\mathrm{M} 12 ; 3-d_{0}=6 \mathrm{MM}, d_{1}=\mathrm{M} 10 ; 4-d_{0}=5 \mathrm{MM}$, $d_{1}=\mathrm{M} 8 ; 5-d_{0}=4 \mathrm{мм}, d_{1}=\mathrm{M} 6 ; 6-$ согласно рис. 4 


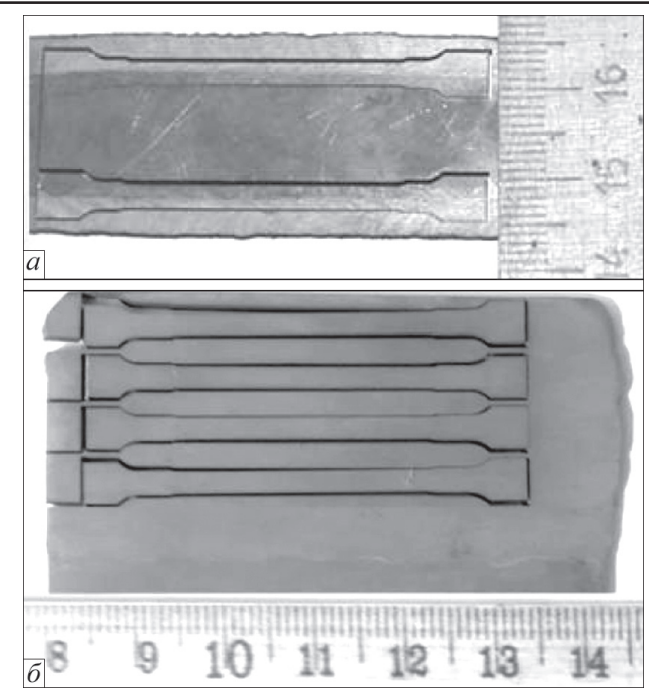

Рис. 6. Внешний вид исходных сварных заготовок со схемой вырезки образцов для высокотемпературных механических испытаний: $a-50 \%$ ЖС6У(ОМ)+50 \% ЖС6К(НМ); б-ЖС6К $(\mathrm{HM})$

ковременных механических свойств для трех типов образцов (основной, 50 \% основного металла ЖС6У+50 \% наплавленного металла ЖС6К; 100 \% наплавленный металл ЖС6К), а также табличные данные по основному металлу ЖС6У и ЖС6К [19].

Установлено, что для получения оптимального уровня свойств при $1000{ }^{\circ} \mathrm{C}$ наплавленного металла ЖС6К и переходной зоны ОМ ЖС6У - НМ ЖС6К требуется термическая обработка в виде гомогенизации при температуре $1220{ }^{\circ} \mathrm{C}$ в течение 4 ч. Последующее старение по режиму $950{ }^{\circ} \mathrm{C}-4$ ч, часто применяемое на практике для диффузионного отжига перенанесенных защитных покрытий, без значительного изменения прочностных характеристик наплавленного металла ЖС6К ограничивает его пластичность, приближая ее к соответствующим значениям основного металла ЖС6У. При этом в переходной зоне ОМ ЖС6У - НМ ЖС6К наблюдается некоторое снижение значений предела текучести и повышение пластичности.

Показано, что после гомогенизации в течение 4 ч, а также после последующего старения по режиму $950{ }^{\circ} \mathrm{C}-4$ ч в испытанных при $1000{ }^{\circ} \mathrm{C}$ об-

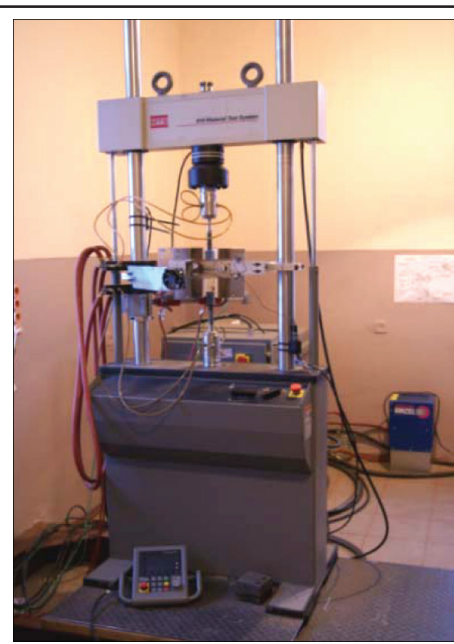

Рис. 7. Внешний вид сервогидравлической машины MTS-810 для высокотемпературных испытаний трудносвариваемых никелевых жаропрочных сплавов

разцах достигается достаточно высокий уровень прочностных свойств по сравнению с основным металлом ЖС6У и ЖС6К. На образцах 50 \% ОМ ЖС6У + 50 \% НМ ЖС6К, имитирующих район линии сплавления при восстановлении бандажной полки лопатки, достигается следующий уровень равнопрочности по сравнению с основным металлом ЖС6У: для значений предела текучести $\sigma_{0,2}$ - не менее 0,78 ; предела прочности $\sigma_{\text {в }}$ - примерно 1,0. На образцах 100 \% НМ ЖС6К, имитирующих восстановленную часть бандажной полки лопатки, достигается следующий уровень равнопрочности по сравнению с основным металлом ЖС6У: по значениям предела текучести $\sigma_{0.2}$ не менее 0,65 ; предела прочности $\sigma_{\text {в }}$ с не менее 0,80 .

Таким образом установлено, что соединение трудносвариваемых никелевых жаропрочных сплавов «основной-наплавленный металл» системы ЖС6У-ЖС6К, выполненное микроплазменной порошковой наплавкой, обеспечивает при $1000{ }^{\circ} \mathrm{C}$ уровень жаропрочности не менее $0,65 \ldots 0,80$ относительно основного металла ЖС6У, что соответствует первичным рекомендациям по обеспечению работоспособности мате-

Таблица 4. Значения показателей кратковременной прочности образцов на статическое растяжение при $1000^{\circ} \mathrm{C}$

\begin{tabular}{|c|c|c|c|c|}
\hline Вид образца & Режим термической обработки & $\sigma_{0,2}, \mathrm{M \Pi а}$ & $\sigma_{\mathrm{B}}, \mathrm{MПа}$ & $\delta, \%$ \\
\hline \multirow{4}{*}{100 \% НМ ЖС6К } & $1050{ }^{\circ} \mathrm{C}-2,5$ ч & 322,5 & 380,5 & 0,35 \\
\hline & $1220^{\circ} \mathrm{C}-2$ ч & 256,3 & 300,9 & 5,80 \\
\hline & $1220^{\circ} \mathrm{C}-4$ ч & 307,2 & 415,3 & 7,20 \\
\hline & $1220^{\circ} \mathrm{C}-4$ ч $+950^{\circ} \mathrm{C}-4$ ч & 315,0 & 406,0 & 2,60 \\
\hline \multirow{3}{*}{$\begin{array}{l}50 \% \text { ОМ ЖС6У + } \\
+50 \% \text { НМ ЖС6К }\end{array}$} & $1220^{\circ} \mathrm{C}-2$ ч. & 403,9 & 496,2 & 3,14 \\
\hline & $1220^{\circ} \mathrm{C}-4$ ч. & 427,0 & 516,1 & 1,60 \\
\hline & $1220^{\circ} \mathrm{C}-4$ ч $+950^{\circ} \mathrm{C}-4$ ч & 372,0 & 509,0 & 3,70 \\
\hline ЖС6У ОМ & $1220^{\circ} \mathrm{C}-4$ ч & 428,4 & 504,8 & 5,5 \\
\hline ЖС6К ОМ [19] & $1220^{\circ} \mathrm{C}-4$ ч & $300 \ldots 320$ & $500-570$ & 4,5 \\
\hline ЖС6У ОМ [19] & $1220^{\circ} \mathrm{C}-4$ ч & $460 \ldots 500$ & 520 & $1,0 \ldots 2,0$ \\
\hline
\end{tabular}


риала восстановленной бандажной полки рабочей лопатки турбины.

\section{Выводы}

Для получения объективной оценки прочностных свойств соединений «основной-наплавленный металл» трудносвариваемых никелевых жаропрочных сплавов с содержанием упрочняющей $\gamma^{\prime}$-фазы более 50 об. \%, необходимо предварительно выбирать геометрические размеры исходной заготовки и образца для механических испытаний с целью обеспечения их технологической прочности как в процессе сварки плавлением, так и в процессе последующей термической обработки.

Анализ методик оценки прочностных свойств наплавленного металла, регламентированных действующей НТД (ГОСТ, ДСТУ, ISO), показал, что приведенное выше условие для соответствующих соединений никелевых жаропрочных сплавов типа ЖС6 не может быть выполнено из-за требований искусственного увеличения жесткости сварного соединения (стыковой шов) увеличенных габаритов захватной части цилиндрических образцов (диаметр не менее 12 мм) или общей длины плоских образцов (не менее 190 мм).

Ввиду нерациональности требований действующей НТД применительно к оценке прочностных свойств таких соединений из трудносвариваемых никелевых жаропрочных сплавов возникла необходимость разработки специализированной методики.

На основе базовых рекомендаций действующей НТД предложена рациональная форма плоского пропорционального образца с рабочим сечением 6...10 мм². Габариты захватной части такого образца предельно уменьшены за счет применения промежуточных переходников к захватам испытательной машины MTS-810.

Установлено, что для получения оптимального при $1000{ }^{\circ} \mathrm{C}$ уровня свойств для наплавленного металла ЖС6К и его переходной зоны в районе линии сплавления с основным металлом ЖС6У требуется термическая обработка в виде гомогенизации при температуре $1220{ }^{\circ} \mathrm{C}$ в течение 4 ч и последующего старения при температуре $950{ }^{\circ} \mathrm{C}$ в течение 4 ч.

\section{Список литературы}

1. Пейчев Г.И. (2005) Ремонт изношенных в процессе эксплуатации элементов конструкции бандажных полок литых рабочих лопаток турбины из сплавов типа ЖС. Авиачионно-космическая техника и технология, 9(25), 221-223.

2. Ющенко К.А., Савченко В.С., Яровицын А.В. и др. (2010) Разработка технологии восстановления торцов бандажных полок рабочих лопаток ТВД авиационного двигателя Д18Т методом микроплазменной порошковой наплавки. Автоматическая сварка, 8, 25-29.
3. Жеманюк П.Д., Петрик И.А., Чигилейчик С.Л. (2015) Опыт внедрения восстановительной микроплазменной порошковой наплавки при ремонте лопаток турбин высокого давления в условиях серийного производства. Там же, 8, 43-46.

4. Ющенко К.А., Яровицын А.В. (2012) Совершенствование технологии восстановления верхней бандажной полки рабочих лопаток авиационного ГТД. Цільова комплексна програма НАН Украӥни «Проблеми ресурсу $i$ безпеки експлуатаиії конструкиій споруд та машин». Зб. наукових статей за результатами, отриманими в 20102012 pp. IЕЗ ім. Є.О. Патона, Київ, 2012, сс. 506-509.

5. Ющенко К.А., Яровицын А.В., Червяков Н.О. (2016) Закономерности дискретно-аддитивного формирования микрообъемов кристаллизующегося металла при многослойной микроплазменной порошковой наплавке никелевых сплавов. Автоматическая сварка, 5-6, 154-161.

6. Жеманюк П.Д., Петрик И.А., Чигилейчик С.Л. и др. (2016) Особенности управления формой валика при однослойной микроплазменной порошковой наплавке на кромки лопаток авиационных ГТД. Автоматическая сварка, 11, 26-34.

7. Ющенко К.А., Яровицын А.В., Червяков Н.О. (2017) Влияние энергетических показателей режимов на склонность к образованию трещин при микроплазменной порошковой наплавке никелевого сплава ЖС 32 . Там же, $\mathbf{2}$, 3-7.

8. ГОСТ 6996-66 (ИСО 4136-89, ИСО 5173-81, ИСО 517781) Сварные соединения. Методы определения механических свойств (с Изменениями N 1, 2, 3, 4).

9. (2015) ДСТУ EN ISO 15792-1:2015 Матеріали зварювальні. Частина 1. Методи випробувань із наплавленого металу зварного шва зі сталі, нікелю і нікелевих сплавів.

10. (2015) ДСТУ EN ISO 15792-2:2015 Матеріали зварювальні. Частина 2. Підготовка зразків для випробувань одно- та двосторонніх з'єднань із сталі.

11. (2015) ДСТУ EN ISO 5178:2015 Випробування руйнівні зварних з'єднань металевих матеріалів. Випробування на повздовжне розтягування зварного шва в з'єднаннях, виконаних зварюванням плавленням.

12. (2015) ДСТУ EN ISO 4136-1:2015 Випробування руйнівні металевих матеріалів. Випробування на розтягування зразка з поперечним швом.

13. (2011) ISO 6892-2:2011 Metallic materials. Tensile testing. Part 2: Method of test at elevated temperature.

14. DuPont John N., Lippold John C., Kisser Samuel D. (2009) Welding metallurgy and weldability of nickel-base alloys. John Willey\&Sons, Inc., Hoboken, New Jersey.

15. Яровицын А.В. (2015) Энергетический подход при анализе режимов микроплазменной порошковой наплавки. Автоматическая сварка, 5-6, 18-25.

16. (1984) ГОСТ 1497-84 Металль. Методы испытаний на растяжение (действует по 01.01.2021).

17. (2006) ДСТУ ЕN 10002-1:2006 Матеріали металеві. Випробування на розтяг. Частина 1. Метод випробування за кімнатної температури.

18. Коваль А.Д., Андриенко А.Г., Гайдук С.В., Кононов В.В. (2012) Оптимизация режима термической обработки для сплава ЖСЗЛС, легированного гафнием и танталом. Новi матеріали в металургії та машинобудуванні, 2, 15-19.

19. Кишкин С.Т. (2006) Создание, исследование и применение жаропрочных сплавов. Избранные труды. Москва, Наука.

\section{References}

1. Pejchev, G.I. (2005) Repair of structure components worn out during operation of flange platforms of turbine cast blades from alloys of ZhS type. Aviats.-Kosmich. Tekhnika $i$ Tekhnologiya, 9(25), 221-223 [in Russian].

2. Yushchenko, K.A., Savchenko, V.S., Yarovitsyn, A.V. et al. (2010) Development of the technology for repair microplasma power cladding of flange platform faces of aircraft engine high-pressure turbine blades. The Paton Welding J., 8, 21-24. 
3. Zhemanyuk, P.D., Petrik, I.A., Chigilejchik, S.L. (2015) Experience of introduction of the technology of reconditioning microplasma powder surfacing at repair of high-pressure turbine blades in batch production. Ibid., 8, 3942 .

4. Yushchenko, K.A., Yarovitsyn, A.V. (2012) Improvement of technology of repair of upper flange platform of aircraft gas turbine engine blades. In: Special-purpose program of $N A S U$ of Ukraine: Problems of life and safety of constructions and Machines: Collect. of the results of 2010-2012. Kyiv, PWI, 506-509 [in Russian].

5. Yushchenko, K.A., Yarovitsyn, A.V., Chervyakov, N.O. (2016) Dependencies of discrete-additive formation of microvolumes of metal being solidified in multilaye microplasma powder surfacing of nickel alloys. The Paton Welding J., 5-6, 143-149.

6. Zhemanyuk, P.D., Petrik, I.A., Chigilejchik, S.L. (2016) Peculiarities of bead shape regulation in single-layer microplasma surfacing on edges of aircraft gas turbine engine blades. Ibid., 11, 23-40.

7. Yushchenko, K.A., Yarovitsyn, A.V., Chervyakov, N.O. (2017) Effect of energy parameters of microplasma powder surfacing modes on susceptibility of nickel alloy ZhS32 to crack formation. Ibid., 2, 2-6.

8. GOST 6996-66 (ISO 4136-89, ISO 5173-81, ISO 517781): Welded joints. Methods of mechanical properties determination (with modifications 1, 2, 3,4) [in Russian].

9. (2015) DSTU EN ISO 15792-1:2015: Welding consumables Pt 1. Tests methods for all-weld metal test specimens in steel, nickel and nickel alloys [in Ukrainian].
10. (2015) DSTU EN ISO 15792-2:2015: Welding consumables. Pt 2. Preparation of single-run and two-run technique test specimens in steel [in Ukrainian].

11. (2015) DSTU EN ISO 5178:2015: Destructive tests on welds in metallic materials. Longitudinal tensile test on weld metal in fusion welded joints [in Ukrainian].

12. (2015) DSTU EN ISO 4136-1:2015: Destructive tests on welds in metallic materials. Transverse tensile test [in Ukrainian].

13. (2011) ISO 6892-2:2011: Metallic materials. Pt 2. Method of test at elevated temperature.

14. DuPont, J.N., Lippold, J.C., Kisser, S.D. (2009) Welding metallurgy and weldability of nickel-base alloys. John Wiley \& Sons, Inc. Hoboken, New Jersey.

15. Yarovitsyn, A.V. (2015) Energy approach in analysis of microplasma powder surfacing modes. The Paton Welding J., 5-6, 14-21.

16. (1984) GOST 1497-84: Metals. Tensile testing methods (valid to 01.01.2021) [in Russian].

17. (2006) DSTU EN 10002-1:2006: Metallic materials. Tensile tests. Pt 1. Testing method at room temperature [in Ukrainian].

18. Koval, A.D., Andrienko, A.G., Gajduk, S.V., Kononov, V.V. (2012) Optimization of heat treatment mode for alloy ZhS3LS doped with hafnium and tantalum. Novi Materialy v Metalurgii ta Mashynobuduvanni, 2, 15-19 [in Russian].

19. Kishkin, S.T. (2006) Development, investigation and application of high-temperature alloys. Moscow, Nauka [in Russian].

\section{ОЦІНКА КОРОТКОЧАСНИХ МЕХАНІЧНИХ ВЛАСТИВОСТЕЙ З’СДНАНЬ ВАЖКОЗВАРЮВАЛЬНИХ НІКЕЛЕВИХ ЖАРОМІЦНИХ СПЛАВІВ ТИПУ ЖС6}

К.А. Ющенко, О.В. Яровицин, М.О. Черв'яков, Г.В. Звягінцева, І.Р. Волосатов, Г.Д. Хрущов

IE3 ім. Є.О. Патона НАН України. 03150, м. Київ, вул. Казимира Малевича, 11. E-mail: office@paton.kiev.ua

Розроблено методику оцінки короткочасних механічних властивостей зварного з'єднання «основний-наплавлений метал» важкозварювальних нікелевих жароміцних сплавів типу ЖС6 при високих температурах, що імітує відновлення крайок робочих лопаток авіаційних газотурбінних двигунів при їх серійному ремонті. Обгрунтовано, виходячи 3 умови забезпечення технологічної міцності такого зварного з'єднання необхідність граничного зменшення в порівнянні 3 діючою нормативно-технічною документацією розмірів зварних заготовок і зразків для механічних випробувань. Розроблена методика випробувана на сервогідравлічній машині MTS-810 при випробуваннях зразків. Вона дозволила обгрунтувати вибір режимів попередньої термічної обробки з метою отримання оптимальних характеристик міцності наплавленого металу ЖС6К. Бібліогр. 19, табл. 4, рис. 7.

Ключові слова: мікроплазмове порошкове наплавлення, робочі лопатки ГТД, ремонт бандажних полиць, важкозварювальний нікелевий сплав, зварне з'єднання, технологічна міцність, підготовка зразків, механічні властивості, висока meмnература

\section{PECULIARITIES OF EVALUATION OF SHORT-TERM MECHANICAL PROPERTIES OF A JOINT OF DIFFICULT-TO-WELD NICKEL HIGH-TEMPERATURE ALLOYS OF ZHS6 TYPE}

K. A. Yushchenko, A. V. Yarovitsyn, N. O. Chervyakov, A. V. Zvyagintseva, I. R. Volosatov, G. D. Khrushchov

E. O. Paton Electric Welding Institute of the NAS of Ukraine.

11 Kazimir Malevich Str., 03150, Kyiv, Ukraine. E-mail: office@paton.kiev.ua

A procedure was developed for evaluation of short-term mechanical properties of "base - deposited metal" welded joint of difficult-to-weld nickel high-temperature alloys of ZhS6 type at high-temperatures, simulating restoration of edges of blades of aircraft gas-turbine engines at their serial repair. The need of limiting reduction in comparison with acting reference documents of sizes of welded billets and samples for mechanical tests was shown following the condition to provide technological strength of such welded joint. The developed procedure was tested on servohudraulic machine MTS-810 during samples' testing. It allowed making ground for selection of the modes of preliminary heat treatment in order to get optimum strength properties of deposited metal ZhS6K. 19 Ref., 4 Tabl., 7 Fig.

Keywords: microplasma powder surfacing, GTE blades, repair of shrouds, difficult-to-weld nickel alloy, welded joint, technological strength, sample preparation, short-term mechanical properties, high temperature 


\title{
ПОРОШКОВАЯ ПРОВОЛОКА ДЛЯ ВОССТАНОВЛЕНИЯ НАПЛАВКОЙ ИЗНОШЕННЫХ ПОВЕРХНОСТЕЙ ЖЕЛЕЗНОДОРОЖНЫХ КОЛЕС*
}

\begin{abstract}
В.Д. Позняков, А.А. Гайворонский, А.В. Клапатюк, А.С. Шишкевич, В.А. Ящук
ИЭС им. Е.О. Патона НАН Украины. 03150, г. Киев, ул. Казимира Малевича, 11. E-mail: office@paton.kiev.ua

Выполнены исследования и разработана порошковая проволока марки ПП-АН180МН/98 для восстановления наплавкой износа перспективных железнодорожных колес повышенной прочности. Определен комплекс физико-механических свойств наплавленного металла. Установлено, что при применении проволоки ПП-АН180МН/98 для наплавки колес повышенной прочности, независимо от температуры предварительного подогрева и количества слоев наплавки, твердость наплавленного металла является оптимальной $(0,94 \ldots 1,0$ твердости рельса). При этом на всех участках соединения (в наплавленном металле, зоне сплавления и на участке перегрева металла ЗТВ) формируется сравнительно однородная бейнитно-мартенситная структура. Наплавленный металл отличается высоким уровнем сопротивляемости хрупкому разрушению и износу при трении-скольжении в контакте с рельсовой сталью. Полученные результаты исследований позволяют заключить, что при применении порошковой проволоки ПП-АН180МН/98 для наплавки восстановленные колеса будут иметь высокую надежность и будет обеспечена безопасность движения транспорта в условиях растущих эксплуатационных нагрузок. Библиогр. 17, табл. 5, рис. 4.
\end{abstract}

Ключевые слова: электродуговая наплавка, железнодорожное колесо, порошковая проволока, структура, механические свойства, хрупкое разрушение, износ

Для изготовления колес грузовых вагонов в Украине сегодня используется высокопрочная колесная сталь марки 2, содержание углерода в которой составляет 0,55...0,65\%. Данная сталь обеспечивает достаточно высокие показатели механических свойств металла колеса - предел прочности $\sigma_{\mathrm{B}}=930 \ldots 1130$ МПа, твердость обода колеса $H B \geq 2500$ МПа $[1,2]$. Колеса, изготовленные из такой стали, при относительно небольшой стоимости имеют достаточно высокую надежность при эксплуатации. Уровень нагрузки на ось колесной пары грузовых вагонов при эксплуатации на железнодорожных путях Украины и стран СНГ составляет до 23,5 т.

В процессе эксплуатации колеса изнашиваются по профилю качения. Из-за особенностей работы пары трения-качения «колесо-рельс» более интенсивно изнашивается рабочая поверхность гребня колеса, а на поверхности катания колес часто образуются дефекты типа «выщерблины». Износ гребня происходит в результате механического трения, а при образовании «выщерблин» реализуется термомеханический характер возникновения дефекта вследствие формирования закалочных структур в приповерхностном слое металла колеса [3-5].

Традиционно при восстановлении изношенных гребней колес применяют технологии наплавки,

\footnotetext{
* По материалам доклада, представленного на Международной конференции «Материалы для сварки, наплавки, нанесения покрытий и 3D-технологий», 04-05 июня 2019 г.,
} г. Киев. что экономически выгодно. Восстановление износа гребня наплавкой позволяет уменьшить отходы металла обода при механической обточке по профилю катания колеса, а также снизить износ гребня за счет наплавки металла с заданными свойствами на его поверхность $[6,7]$. Колеса с «выщерблинами» сегодня наплавкой не восстанавливают, и их подвергают обточке до полного устранения дефектов.

В настоящее время для наплавки гребней железнодорожных колес рекомендовано применение проволок сплошного сечения типа Св-08ХМ, Св-08ХМФ и Св-10ХН2ГСМФТЮ, а также порошковую проволоку марки ПП-АН180МН/90 (система легирования 10ХНМГСФТ). Наплавка проволоками сплошного сечения выполняется под слоем флюса, а порошковой проволокой - как под флюсом, так и в среде защитных газов. Металл, наплавленный с применением данных сварочных материалов, отвечает уровню прочности и твердости железнодорожных колес, изготовленных из колесной стали марки 2, а также отличается повышенной износостойкостью.

Современные тенденции развития отечественного магистрального железнодорожного транспорта направлены на увеличение нагрузки на ось до 27,5 т и скорости движения грузовых поездов до 150 км/ч, что требует применения колес более высокой прочности, металл которых бы имел достаточно высокий уровень трещиностойкости и износостойкости. В связи с этим сегодня в Украине, на основании колесной стали марки 2,

( ) В.Д. Позняков, А.А. Гайворонский, А.В. Клапатюк, А.С. Шишкевич, В.А. Ящук, 2019 
Таблица 1. Химический состав наплавленного металла опытных порошковых проволок, мас. \%

\begin{tabular}{|c|c|c|c|c|c|c|c|c|c|}
\hline Проволока ПП-АН180MH/90 & $\mathrm{C}$ & $\mathrm{Si}$ & $\mathrm{Mn}$ & $\mathrm{Cr}$ & $\mathrm{Ni}$ & $\mathrm{Ti}$ & $\mathrm{V}$ & $\mathrm{S}$ & $\mathrm{P}$ \\
\hline $\mathrm{I}$ & 0,07 & 0,42 & 0,8 & 0,8 & 0,5 & 0,018 & 0,08 & 0,01 & 0,025 \\
\hline $\mathrm{II}$ & 0,14 & 0,62 & 1,3 & 1,1 & 0,7 & 0,028 & 0,10 & 0,02 & 0,025 \\
\hline $\mathrm{III}($ ПП-AH180MH/98) & 0,12 & 0,48 & 1,15 & 0,96 & 0,7 & 0,022 & 0,10 & 0,02 & 0,03 \\
\hline $\mathrm{IV}$ & 0,067 & 0,45 & 1,02 & 0,32 & 0,4 & 0,016 & 0,10 & 0,01 & 0,01 \\
\hline
\end{tabular}

разрабатываются новые колесные стали, повышение физико-механических свойств которых решается путем их микролегирования карбо- и нитридообразующими элементами [8-10].

Очевидно, что рекомендованные сварочные материалы не могут быть использованы для восстановления наплавкой разрабатываемых колес повышенной прочности. Поэтому целью настоящей работы было создание нового сварочного материала, с применением которого наплавленный металл соответствовал бы комплексу свойств металла колес повышенной прочности. Это позволит существенно увеличить ресурс эксплуатации новых колес и обеспечить безопасность движения на железнодорожном транспорте при повышении эксплуатационных нагрузок.

Методы исследований. При разработке нового сварочного материала применялись методы физических испытаний для оценки прочностных, пластических свойств и ударной вязкости наплавленного металла согласно ГОСТ 1497 и ГОСТ 9454. Износостойкость определяли в соответствии с принятыми методами испытаний на износ при «трении-скольжении» контактируемых поверхностей металлических изделий $[11,12]$. Сопротивляемость наплавленного металла хрупкому разрушению оценивали при трехточечном изгибе с использованием критериев механики разрушения $[13,14]$. При исследованиях структурных изменений в металле применяли традиционные методы оптической микроскопии.

В качестве объекта исследований использовали металл, наплавленный проволокой ПП-АН180МН/90 и новым разрабатываемым сварочным материалом. В некоторых экспериментах для сравнения использовались проволоки марок Св-08ХМ и Св-10ХН2ГСМФТЮ.

Разработка сварочного материала. Для разработки нового сварочного материала за основу была взята порошковая проволока марки ПП-АН180МН/90 (10ХНМГСФТ). В качестве шлаковой системы новой порошковой проволоки была выбрана система $\mathrm{CaO}-\mathrm{MgO}-\mathrm{CaF}_{2}-\mathrm{SiO}_{2}$, которая традиционно используется в ряде проволок типа ПП-АН180МН. Опытные составы наплавленного металла при разработке новой проволоки показаны в табл. 1.
Одним из основных показателей механических характеристик наплавленного металла, который определяет его эксплуатационные свойства, является твердость. Для определения показателей твердости наплавленного металла на первом этапе разработки проволоки выполняли сравнительные одно-, двух- и трехслойные наплавки в среде защитных газов на погонной энергии 8,5...10 кДж/см² на образцы колесной стали марки $2(0,58 \%$ C) размером $200 \times 100 \times 20$ мм. Температура предварительного подогрева составляла $150{ }^{\circ} \mathrm{C}$, как и при наплавке гребней железнодорожных колес. Твердость определяли на поверхности наплавки с применением твердомера марки ТК в единицах $H R C$ с последующим переводом в единицы $H B$. Результаты замеров твердости приведены в табл. 2 .

Как видно, твердость 1-го, 2-го и 3-го слоев наплавленного металла, выполненного опытной порошковой проволокой II, превышает твердость рельсовой стали $(H B \geq 3200 \mathrm{MПа})$. Оптимизированные легирующая и шлаковая системы опытной порошковой проволоки III обеспечивают стабильные показатели твердости 2-го и 3-го слоев наплавленного металла (на уровне 3000 ...3200 МПа). С легирующей системы порошковой проволоки удален молибден без снижения механических и технологических характеристик. Опытный образец порошковой проволоки ПП-АН180МН/90 (III) был взят за основу и получил рабочую марку ПП-АН180МН/98.

Структура наплавленного металла при использовании проволоки ПП-АН180МН/90 и ПП-АН$180 \mathrm{MH} / 98$ характеризуется как бейнитно-мар-

Таблица 2. Твердость наплавленного метала в зависимости от химического состава и количества слоев наплавки $\left(T_{\text {пп }}=\right.$ $=150^{\circ} \mathrm{C}$ )

\begin{tabular}{|c|c|c|}
\hline $\begin{array}{c}\text { Проволока } \\
\text { ПП-АН180МН/90 }\end{array}$ & $\begin{array}{c}\text { Количество слоев } \\
\text { наплавки }\end{array}$ & НВ, МПа \\
\hline \multirow{3}{*}{ I } & 1 & $2500 \ldots 2700$ \\
\hline & 2 & $2300 \ldots 2500$ \\
\hline & 3 & $2000 \ldots 2300$ \\
\hline \multirow{3}{*}{ II } & 1 & $3200 \ldots 3700$ \\
\hline & 2 & $3500 \ldots 3600$ \\
\hline & 3 & $3400 \ldots 3500$ \\
\hline \multirow{3}{*}{$\begin{array}{c}\text { III } \\
(\Pi \Pi-А H 180 M H / 98)\end{array}$} & 1 & $3200 \ldots 3500$ \\
\hline & 2 & $3000 \ldots 3200$ \\
\hline & 3 & $2800 \ldots 3100$ \\
\hline \multirow{3}{*}{ IV } & 1 & $2400 \ldots 2700$ \\
\hline & 2 & $2200 \ldots 2400$ \\
\hline & 3 & $2000 \ldots 2200$ \\
\hline
\end{tabular}




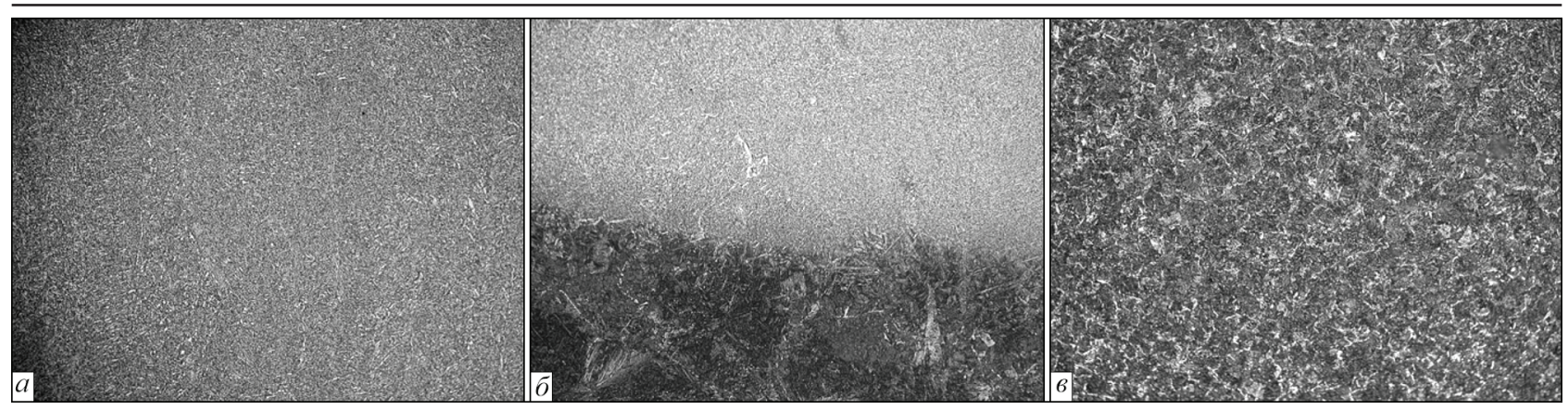

Рис. 1. Микроструктура (×200) однослойной наплавки проволокой ПП-АН180МН/98, выполненной на погонной энергии 8,9 кДж/см при $T_{\text {пा }}=100{ }^{\circ} \mathrm{C}: a-$ наплавленный металл; $\sigma$ - зона сплавления; в- - участок перегрева металла ЗТВ

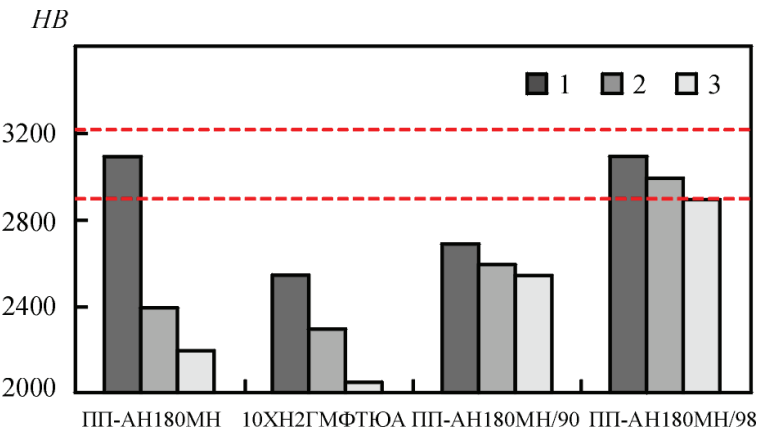

Рис. 2. Твердость наплавленного металла при $T_{\text {пп }}=250^{\circ} \mathrm{C}$ : 1 - 1-й слой; 2 - 2-й слой; 3 - 3-й слой

тенситная. При наплавке без предварительного подогрева проволокой ПП-АН180МН/90 соотношение структурных составляющих бейнита и мартенсита составляет 55/45, при предварительном подогреве $100{ }^{\circ} \mathrm{C}-70 / 30$. При наплавке в аналогичных условиях проволокой ПП-АН180МН/98 соотношение бейнита и мартенсита соответственно $50 / 50$ и 65/35. Микротвердость структурной составляющей бейнита в зависимости от температуры предварительного подогрева изменяется в диапазоне от 2820 до 3090 МПа, мартенсита — от 3290 до 3660 МПа. В зоне сплавления и на участке крупного зерна в 3ТВ доля бейнита повышается до $75 \%$. Характерные структуры металла соединений при наплавке проволокой ПП-АН180MH/98 показаны на рис. 1.

Таблица 3. Твердость металла при наплавке проволокой ПП-АН180МН/98 $\left(T_{\Pi \Pi}=150{ }^{\circ} \mathrm{C}\right)$

\begin{tabular}{|c|c|c|c|}
\hline $\begin{array}{c}\text { Способ на- } \\
\text { плавки }\end{array}$ & $\begin{array}{c}\text { Погонная энер- } \\
\text { гия наплавки, } \\
\text { кДж/см }\end{array}$ & $\begin{array}{c}\text { Количество } \\
\text { слоев на- } \\
\text { плавки, шт. }\end{array}$ & НВ, МПа \\
\hline \multirow{3}{*}{ В среде $\mathrm{CO}_{2}$} & \multirow{3}{*}{$8,5 \ldots 10$} & 1 & $3200 \ldots 3500$ \\
\hline & & 2 & $3100 \ldots 3150$ \\
\hline & & 3 & $3000 \ldots 3200$ \\
\hline \multirow{3}{*}{$\begin{array}{l}\text { Под слоем } \\
\text { флюса АН-60 }\end{array}$} & \multirow{3}{*}{$9 \ldots 11$} & 1 & $3200 \ldots 3500$ \\
\hline & & 2 & $3000 \ldots 3200$ \\
\hline & & 3 & $2800 \ldots 3100$ \\
\hline
\end{tabular}

Таблица 4. Механические свойства металла при наплавке проволокой ПП-АН180MН/98 $\left(T_{\text {пп }}=150{ }^{\circ} \mathrm{C}\right.$, способ наплавки - в среде $\mathrm{CO}_{2}$ )

\begin{tabular}{|c|c|c|c|c|c|c|c|}
\hline \multirow{2}{*}{$\begin{array}{l}\sigma_{0,2}, \\
\text { МП̈ }\end{array}$} & \multirow{2}{*}{$\begin{array}{c}\sigma_{\mathrm{B}}, \\
\mathrm{MПа}\end{array}$} & \multirow{2}{*}{$\delta_{5}, \%$} & \multirow{2}{*}{$\psi, \%$} & \multicolumn{3}{|c|}{$K C U$, Дж/ $\mathrm{cm}^{2}$} & \multirow{2}{*}{$H B$, МПа } \\
\hline & & & & 20 & -40 & -60 & \\
\hline 800 & 890 & 10,7 & 54,3 & 96,0 & 76,8 & 66,5 & $3000 \ldots 3200$ \\
\hline
\end{tabular}

На втором этапе оценили уровень твердости наплавленного металла при наплавке колесной стали марки 2 с предварительным подогревом $250{ }^{\circ} \mathrm{C}$. Такая температура металла характерна для обода колеса после 5-го прохода при беспрерывном процессе наплавки гребня. Результаты исследований приведены на рис. 2. На рисунке для сравнения приведены также данные значений твердости металла, наплавленного другими материалами. Штрихпунктирной линией отмечен уровень твердости колес повышенной прочности. Как видно, порошковая проволока ПП-АН180МН/98 обеспечивает стабильно высокие результаты по твердости наплавленного металла даже при такой температуре.

Порошковая проволока ПП-АН180МН/98 относится к проволокам с малошлаковой основой (шлакообразующих компонентов менее $6 \%$ ), что позволяет исключить негативное влияние сепарации компонентов шихты при производстве проволоки на ее сварочно-технологические свойства и обеспечить стабильность свойств наплавленного металла. Соотношение компонентов, составляющих шлаковую основу, обеспечивает высокие параметры сварочно-технологических свойств в части отделимости шлаковой корки, растекаемости наплавленного металла, формирования поверхности валиков и плавных переходов между валиками и основным металлом. Шлаковая основа проволоки обеспечивает высокую устойчивость против пор при малых затратах защитного газа (8..10 л/мин.) и низкий уровень диффузного водорода в наплавленном металле $\left(0,3 \ldots 0,5 \mathrm{~cm}^{3} / 100\right.$ г), что позволяет говорить о высокой сопротивляемости наплавленного металла образованию холодных трещин.

Легирующая основа сварной проволоки включает такие компоненты как хром, никель, марганец и титан, обеспечивающие достаточно высокую твердость наплавленного металла (табл. 3) при необходимом уровне механических характеристик. Механические свойства наплавленного металла, выполненного проволокой ПП-АН180МН/98, представлены в табл. 4. 


\begin{tabular}{|c|c|c|c|c|}
\hline \multirow{2}{*}{ Сварочный материал } & \multirow{2}{*}{$T_{\text {пाп }},{ }^{\circ} \mathrm{C}$} & \multirow{2}{*}{ Структура наплавленного металла } & \multicolumn{2}{|c|}{$K_{1 c}, \mathrm{M \Pi а} \sqrt{\mathrm{M}}_{\mathrm{M}}$} \\
\hline & & & $20^{\circ} \mathrm{C}$ & $-40^{\circ} \mathrm{C}$ \\
\hline \multirow{2}{*}{ Св-08XМ } & - & Бейнитная & 97,9 & 88,5 \\
\hline & 100 & Бейнитно-перлитная & 86,4 & 69,8 \\
\hline \multirow{2}{*}{ ПП-АН180МН/90 } & - & Бейнитно-мартенситная 55/45 & 105,6 & 92,2 \\
\hline & 100 & Бейнитно-мартенситная 70/30 & 110,3 & 97,7 \\
\hline \multirow{2}{*}{ ПП-АН180МН/98 } & - & Бейнитно-мартенситная 50/50 & 104,2 & 90,6 \\
\hline & 100 & Бейнитно-мартенситная 65/35 & 109,8 & 96,2 \\
\hline
\end{tabular}

Таким образом, оптимизированная легирующая система порошковой проволоки ПП-АН$180 \mathrm{MH} / 98$ обеспечивает более высокие и стабильные показатели твердости наплавленного металла (на уровне $3000 \ldots 3200$ МПа), чем при наплавке другими материалами. Эти показатели являются оптимальными как при однослойной, так и при многослойной наплавке железнодорожных колес. Как показали дальнейшие исследования, наплавленный порошковой проволокой ПП-АН$180 \mathrm{MH} / 98$ металл имеет также повышенную сопротивляемость и хрупкому разрушению.

Сопротивляемость наплавленного металла хрупкому разрушению. Известно, что сопротивляемость наплавленного металла против образования трещин под действием внешнего нагружения зависит от его структурного состояния, которое определяется его химическим составом и скоростью охлаждения. Наличие диффузного водорода в наплавленном металле также существенно влияет на образование и развитие трещин. Количество диффузионного водорода в наплавленном металле определяется способом и режимами сварки, а степень его диффузии - химическим составом и температурой металла.

Образцы наплавленного металла для испытаний вырезали из многослойных соединений, которые выполняли в разделку стыкового соединения с зазором в корне 10 мм. Наплавки выполняли под слоем флюса АН-60. Применяли следующие сварочные материалы: проволока сплошного сечения Св-08ХМ диаметром 3 мм и порошковые проволоки ПП-АН180МН/90 и ПП-АН180МН/98 диаметром 2 мм. Погонная энергия наплавки была в пределах $9 \ldots 11$ кДж/см. Наплавку выполняли без и с предварительным подогревом металла до температуры $T_{\text {пп }}=100{ }^{\circ} \mathrm{C}$. Содержание диффузионного водорода в наплавленном металле, который определяли методом «карандашной пробы», при наплавке проволокой Св-08ХМ составляло $3,5 \ldots 3,8$ мл/100 г, проволоками ПП-АН180МН/90 и ПП-АН180MН/98 - 2,2 ..2,4 мл/100 г.

Предварительно в образцах выращивали трещину усталости глубиной 3,0 мм. В последующем образцы испытывали при трехточечном изгибе.
Критерием оценки сопротивляемости хрупкому разрушению наплавленного металла был критический коэффициент интенсивности напряжений $K_{1 c}$ при разрушении образцов, который подсчитывали согласно стандартных методов механики разрушения [15]. Результаты испытаний наплавленного металла хрупкому разрушению обобщены в табл. 5.

Установлено, что без предварительного подогрева сопротивляемость хрупкому разрушению наплавленного металла при применении порошковых проволок ПП-АН180МН/90 и ПП-АН180МН/98 примерно на $10 \%$ выше, чем при наплавке проволокой Св-08ХМ. При предварительном подогреве до температуры $100{ }^{\circ} \mathrm{C}$ эта разница увеличивается. Повышение критического коэффициента интенсивности напряжений составляет уже $22 \%$ при температуре испытаний $20^{\circ} \mathrm{C}$ и $40 \%$ при $-40{ }^{\circ} \mathrm{C}$. При этом разрушение наплавленного металла, независимо от способа наплавки и температуры предварительного подогрева, при развитии магистральной трещины происходит хрупко.

Следует также отметить, что сопротивляемость металла, наплавленного проволокой Св-08ХМ, хрупкому разрушению, при предварительном подогреве снижается на $12 \%$ при температуре испытаний $20{ }^{\circ} \mathrm{C}$ и на $21 \%$ при $-40{ }^{\circ} \mathrm{C}$. При наплавке порошковыми проволоками, наоборот, при применении предварительного подогрева до температуры $100{ }^{\circ} \mathrm{C}$ сопротивляемость хрупкому разрушению металла шва возрастет примерно на 4 \%.

Установленные изменения в сопротивляемости наплавленного металла хрупкому разрушению в зависимости от системы легирования сварочного материала и температуры предварительного подогрева можно объяснить совместным действием двух факторов. Во-первых, содержание диффузионного водорода в наплавленном порошковыми проволоками металле почти в 1,5 раза ниже, чем при наплавке проволокой Св-08ХМ (2,3 против 3,65 мл/100 г). Во-вторых, это структурный фактор. Закаленный металл, который имеет смешанную бейнитно-мартенситную структуру, имеет более высокую сопротивляемость хрупкому раз- 
рушению, чем металл с только бейнитной структурой, или со структурой, в которой есть доля перлитной составляющей $[14,16]$.

Износостойкость наплавленного металла. Износостойкость является одним из главных показателей эксплуатационной прочности восстановленных наплавкой железнодорожных колес. Износостойкость наплавленного металла оценивали при «трении-скольжении» модельных образцов. Испытания выполняли согласно принятых методов исследований $[12,17]$. В соответствии с методом образец наплавленного металла размером $25 \times 15 \times 3$ мм прижимали к контртелу из рельсовой стали марки М-76, которое вращалось с постоянной скоростью (рис. 3). Усилие прижима образца составляло $81,3 \mathrm{H}$, скорость вращения контртела 30 об/мин, время испытания 30 мин.

В результате контакта образца наплавленного металла и контртела с рельсовой стали происходил износ металлов - на образце образовалась лунка постоянной глубины, а на поверхности контртела образовывалась кольцевидная дорожка. Величину износа контртела по массе $(g$, мг) определяли путем взвешивания до и после нагрузки на аналитических весах (точность 0,0005 г), а износ образца определяли по объему лунки $\left(V, \mathrm{mM}^{3}\right)$.

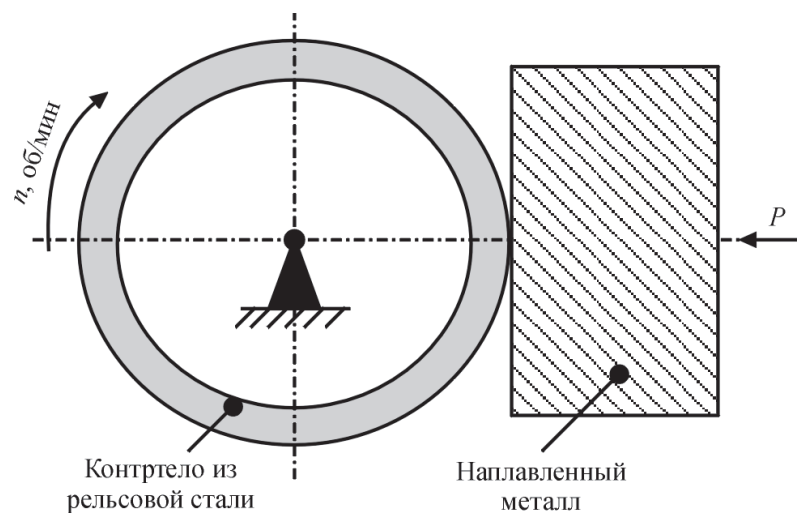

Рис. 3. Условная схема при испытании образцов наплавленного металла при «трении-скольжении»

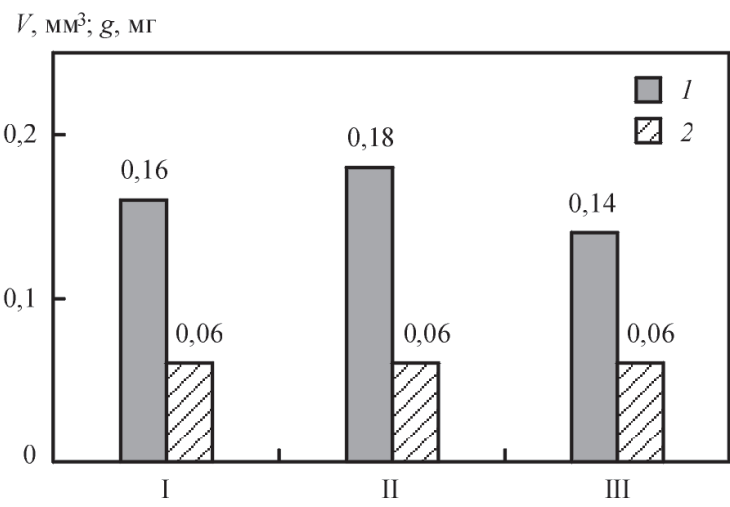

Рис. 4. Износ металла, наплавленного проволоками ПП-АН$180 \mathrm{MH} / 90$ (I, II) и ПП-АН180MН/98 (III) при $T_{\text {пп }}=150{ }^{\circ} \mathrm{C}: \mathrm{I}$, III - наплавка под слоем флюса; II - в среде $\mathrm{CO}_{2}(1-V$, колесная сталь; $2-q$, рельсовая сталь)
Обобщенные результаты испытаний наплавленного металла различных систем легирования приведены на рис. 4.

Как видно из приведенных данных, при наплавке в среде защитного газа проволокой ПП-АН1 80MН/90, в отличие от наплавки под слоем флюса, износостойкость наплавленного металла снижается примерно на 11 \% (поз. 1 и 2). Это связано с особенностями протекания металлургических процессов при различных способах наплавки. При наплавке в среде углекислого газа частичное выгорание титана из металла происходит более интенсивно. При наплавке проволокой ПП-АН180МН/98 под слоем флюса (поз. 3) износостойкость наплавленного металла повышается примерно на $12,5 \%$.

\section{Выводы}

1. На базе порошковой проволоки ПП-АН$180 \mathrm{MH} / 90$, за счет оптимизации системы легирования (10ГСХНФТ) и малошлаковой основы $\left(\mathrm{CaF}_{2}-\mathrm{CaCO}_{3}-\mathrm{MgO}-\mathrm{SiO}_{2}\right)$, которая не подвержена сепарации, разработана новая порошковая проволока ПП-АН180МН/98 (12ГСХ1НФТ).

2. При применении проволоки ПП-АН$180 \mathrm{MH} / 98$ для наплавки колес повышенной прочности, независимо от температуры предварительного подогрева и количества слоев наплавки, твердость наплавленного металла является оптимальной и составляет $H B-3000 \ldots 3200 \mathrm{MПа}$ (твердость рельса $H B \geq 3200 \mathrm{MПа).} \mathrm{При} \mathrm{этом} \mathrm{на}$ всех участках соединения (в наплавленном металле, зоне сплавления и на участке перегрева металла ЗТВ) формируется сравнительно однородная бейнитно-мартенситная структура.

3. Металл, наплавленный проволокой ПП-АН$180 \mathrm{MH} / 98$, имеет высокую сопротивляемость износу при «трении-скольжении» при контакте с рельсом. Износостойкость наплавленного металла, выполненного проволокой ПП-АН180МН/98, на $12,5 \%$ выше, чем при наплавке проволокой ПП-АН180МН/90. При этом износ рельса не увеличивается.

4. Наплавленный металл отличается высоким уровнем сопротивляемости хрупкому разрушению, что позволяет рекомендовать проволоку ПП-АН180МН/98 к применению для наплавки колес повышенной прочности. Восстановленные колеса при этом будут иметь высокую надежность и будет обеспечена безопасность движения транспорта в условиях растущих эксплуатационных нагрузок.

\section{Список литературы}

1. Узлов И.Г. (2003) Прогрессивные процессы производства и качество железнодорожных колес. Сталь, 5, 69-72. 
2. Железнодорожные колеса и бандажи KLW (Интерпайп НТЗ Украина). www.interpipe.biz.

3. Вакуленко I.О., Анофрієв В.Г., Грищенко М.А., Перков О.М. (2009) Дефекти залізничних коліс. Дніпропетровськ, Маковецький.

4. Бабаченко А.И., Кононенко А.А., Дементьева Ж.А. и др. (2010) Исследование причин образования дефектов на поверхности катания высокопрочных колес в процессе эксплуатации. Залізничний транспорт України, 5, 35-38.

5. Осташ О.П., Андрейко I.М., Кулик В.В., Прокопець В.I (2011) Контактно-втомна пошкоджуваність поверхні кочення залізничних коліс типу КП-2 та КП-Т. Вісник Дніпропетровського наи. ун-ту залізн. трансп. ім. акад. В. Лазаряна, 39, сс. 118-122.

6. (1998) Ресурсосберегающие технологии восстановления железнодорожной техники сваркой, наплавкой и напылением. Труды ВНИИЖТ. Лозинский В.Н. (ред.). Москва, Интеллект.

7. Гайворонский А.А., Позняков В.Д., Маркашова Л.И. и др. (2012) Влияние состава наплавленного металла на структуру и механические свойства железнодорожных колес. Автоматическая сварка, 8, 18-24.

8. Узлов И.Г., Бабаченко А.И., Дементьева Ж.А. (2005) Влияние микролегирования стали на вязкость разрушения железнодорожных колес. Металлургия и горнорудная промышленность, 5, 46-47.

9. Бабаченко А.И., Литвиненко П.Л., Кныш А. В. и др. (2011) Совершенствование химического состава стали для железнодорожных колес, обеспечивающего повышение их стойкости к образованию дефектов на поверхности катания. Фундамент. и прикл. проблемы чернои металлургии. Сб. научн. тр. ИЧМ НАН Украины, 23, cс. 226-233.

10. Иванов Б.С., Филипов Г.А., Демин К.Ю. и др. (2007) Модифицирование колесной стали азотом. Сталь, 9, 22-25.

11. Рыбакова Л.М., Куксенова Л.И. (1982) Структура и износостойкость металла. Москва, Машиностроение.

12. Артемов И.И., Савицкий В.Л., Сорокин С.А. (2004) Моделирование изнашивания и прогнозирование ресурса трибосистем. Пенза, Пензенский гос. ун-т.

13. (1972) Новые методы оценки сопротивляемости металлов хрупкому разрушению. Роботнов Ю.Н. (ред.). Москва Мир.

14. Панасюк В.В. (1991) Механика квазихрупкого разрушения материалов. Киев, Наукова думка.

15. ГОСТ 25.506 Методы механических испытаний металлов. Определение характеристик трещиностойкости (вязкости разрушения) при статическом нагружении.

16. Єфіменко М.Г., Радзівілова Н.О. (2003) Металозна вство і термічна обробка зварних з'єднань. Харків, НТУ «ХПІ».

17. Рябцев И.И., Черняк Я.П., Осин В.В. (2004) Блочно-модульная установка для испытаний наплавленного металла, Сварщик, 1, С.18-20.

\section{References}

1. Uzlov, I.G. (2003) Advanced processes of production and quality of railway wheels. Stal, 5, 69-72 [in Russian].

2. Railway wheels and tires KLW. Interpipe NTZ Ukraine, www.interpipe.biz [in Russian].

3. Vakulenko, I.O., Anofriev, V.G., Gryshchenko, M.A., Perkov, O.M. (2007) Defects of railway wheels. Dnipropetrovsk, Makovetsky [in Ukrainian].

4. Babachenko, A.I., Kononenko, A.A., Dementieva, Zh.A. et al. (2010) Examination of causes of defect formation on roll surface of high-strength wheels during operating process. Zaliznychny Transport Ukrainy, 5, 35-38 [in Russian].

5. Ostash, O.P.,Andrejko, I.M., Kulyk, V.V., Prokopets, V.I. (2011) Contact-fatigue damage of roll surface of railway wheels of KP-2 and KP-T type. Visnyk DNUZT, 39, 118-122 [in Ukrainian].

6. (1998) Resource-saving technologies of repair of railway engineering using welding, surfacing and spattering. Trudy VNIIZhT. Ed. by V.N. Lozinsky. Moscow, Intellect [in Russian].

7. Gajvoronsky, A.A., Poznyakov, V.D., Markashova, L.I. et al. (2012) Influence of deposited metal composition on structure and mechanical properties of reconditioned railway wheels. The Paton Welding J., 8, 16-22.

8. Uzlov, I.G., Babachenko, A.I., Dementieva, Zh.A. (2005) Influence of microalloying of steel on fracture toughness of railway wheels. Metallurgiya i Gornorudnaya Promyshlennost, 5, 46-47 [in Russian].

9. Babachenko, A.I., Litvinenko, P.L., Knysh, A.V. et al. (2011) Improvement of chemical composition of steel for railway wheels providing increase of their resistance to defect formation on roll surface. In: Fundamentals and Applied Problems of Ferrous Metallurgy: Transact. of IFM, 23, 226233 [in Russian].

10. Ivanov, B.S., Filipov, G.A., Demin, K.Yu. et al. (2007) Modification of wheel steel by nitrogen. Stal, 9, 22-25 [in Russian].

11. Rybakova, L.M., Kuksenova, L.I. (1982) Structure and wear resistance of metal. Moscow, Mashinostroenie [in Russian].

12. Artemov, I.I., Savitsky, V.L., Sorokin, S.A. (2004) Modeling of wear and prediction of pipe system life. Penza, PSU [in Russian].

13. (1972) New methods of evaluation of metal resistance to brittle fracture. Ed. by Yu.N. Robotnov. Moscow, Mir [in Russian].

14. Panasyuk, V.V. (1991) Mechanics of quasibrittle fracture of materials. Kiev, Naukova Dumka [in Russian].

15. GOST 25.506: Methods of mechanical tests of metals. Determination of characteristics of crack resistance (fracture toughness) at static loading.

16. Efimenko, M.G., Radzivilova, N.O. (2003) Physical metallurgy and heat treatment of welded joints. Kharkiv, NTU KhPI [in Ukrainian].

17. Ryabtsev, I.I., Chernyak, Ya.P., Osin, V.V. (2004) Blockmodule installation for tests of deposited metal. Svarshchik, 1, 18-20 [in Russian].

\title{
ПОРОШКОВИЙ ДРІТ ДЛЯ ВІДНОВЛЕННЯ НАПЛАВЛЕННЯМ ЗНОШЕНИХ ПОВЕРХОНЬ ЗАЛІЗНИЧНИХ КОЛЕС
}

\author{
В.Д. Позняков, О.А. Гайворонський, А.В. Клапатюк, О.С. Шишкевіч, В.А. Ящук
}

IE3 ім. Є.О. Патона НАН України. 03150, м. Київ, вул. Казимира Малевича, 11. E-mail: office@paton.kiev.ua

Виконано дослідження і розроблено порошковий дріт марки ПП-АН180МН/98 для відновлення наплавленням зносу перспективних залізничних коліс підвищеної міцності. Визначено комплекс фізико-механічних властивостей наплавленого металу. Встановлено, що при застосуванні дроту ПП-АН180МН/98 для наплавлення коліс підвищеної міцності, незалежно від температури попереднього підігріву і кількості шарів наплавки, твердість наплавленого металу є оптимальною $(0,94 \ldots 1,0$ твердості рейки). При цьому на всіх ділянках з'єднання (в наплавленому металі, зоні сплаву і на ділянці перегріву металу 3ТВ) формується порівняно однорідна бейнітно-мартенситна структура. Наплавлений метал відрізняється високим рівнем опірності крихкому руйнуванню і зносу при терті-ковзанні в контакті $з$ рейкової сталлю. Отримані результати досліджень дозволяють зробити висновок, що при застосуванні порошкового дроту 
ПП-АН180МНч/98 для наплавлення відновлені колеса будуть мати високу надійність і буде забезпечена безпека руху транспорту в умовах зростаючих експлуатаційних навантажень. Бібліогр. 17, табл. 5, рис. 4.

Ключові слова: електродугове наплавлення, залізничне колесо, порошковий дріт, структура, механічні властивості, крихке руйнування, знос

\section{FLUX-CORED WIRE FOR RESTORATION SURFACING OF WORN SURFACES OF RAILWAY WHEELS}

V.D. Poznyakov, A.A. Gaivoronskiy, A.V. Klapatyuk, A.S. Shishkevich, V.A. Yashchuk

E.O. Paton Electric Welding Institute of the NAS of Ukraine.

11 Kazimir Malevich Str., 03150, Kyiv, Ukraine. E-mail: office@paton.kiev.ua

Research was performed and flux-cored wire of PP-AN180MN/98 grade was developed for restoration of wear by surfacing in advanced higher-strength railway wheels. A set of physico-mechanical properties of the deposited metal was determined. It is found that at application of PP-AN180MN/98 wire for surfacing higher-strength wheels, irrespective of preheating temperature and number of deposited layers, deposited metal hardness is optimum ( $0.94-1.0$ of rail hardness). Here, in all the joint regions (in the deposited metal, fusion zone and overheated region of HAZ metal) a comparatively homogeneous bainite-martensite structure forms. The deposited metal features a high level of resistance to brittle fracture and wear at sliding friction in contact with rail steel. Obtained research results lead to the conclusion that at application of flux-cored wire PP-AN180MN/98 for surfacing, the restored wheels will have a high reliability, and traffic safety with be ensured under the conditions of increasing operating loads. 17 Ref., 5 Tabl., 4 Fig.

Keywords: electric-arc surfacing, railway wheel, flux-cored wire, structure, mechanical properties, brittle fracture, wear

Поступила в редакцию 31.05.2019

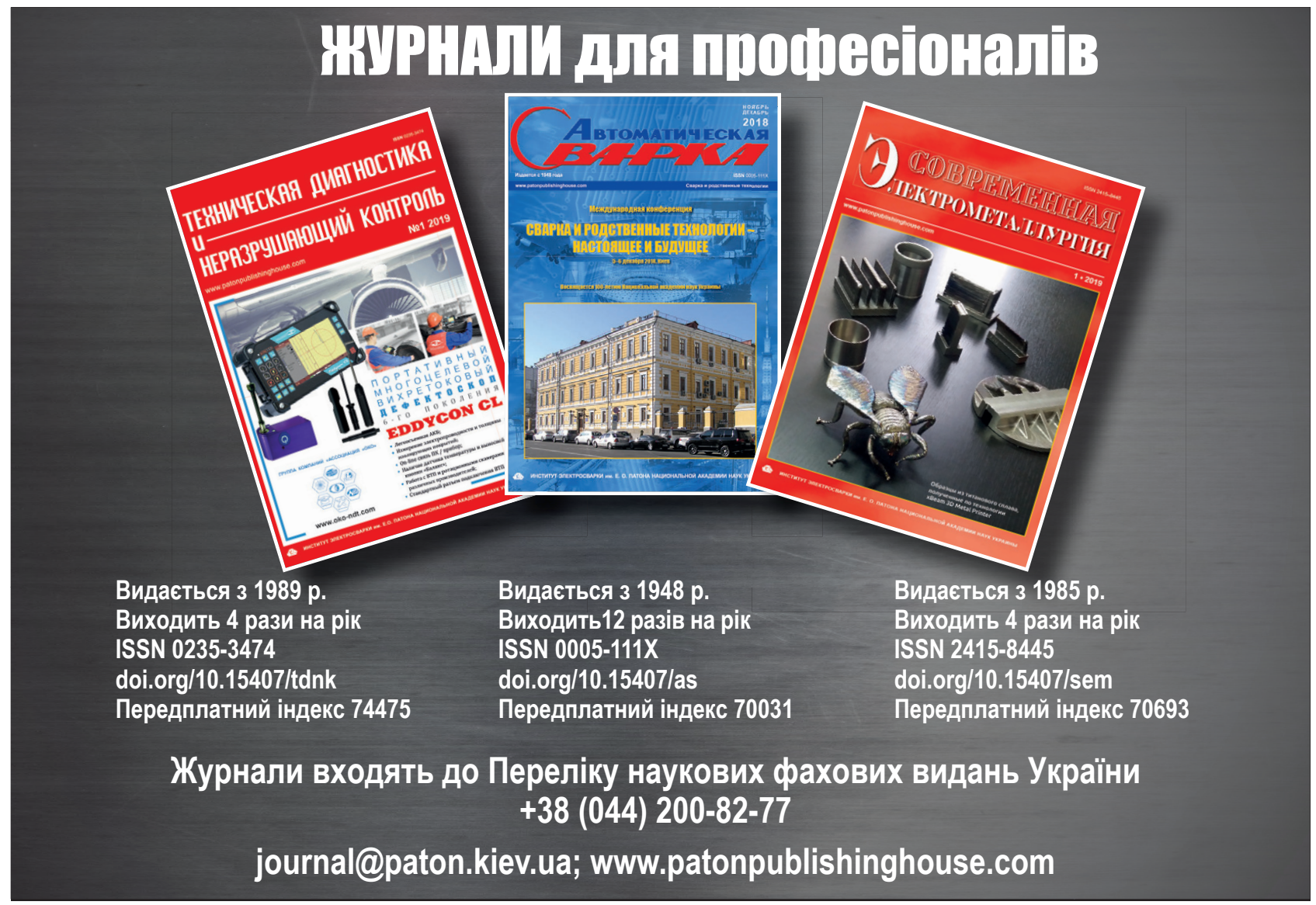




\title{
ФАКТОРЫ РИСКА И КРИТЕРИИ ПОЖАРО- И ВЗРЫВО- ОПАСНОСТИ ПРИ ИЗМЕЛЬЧЕНИИ ФЕРРОСПЛАВОВ*
}

\begin{abstract}
А.Е. Марченко
ИЭС им. Е.О. Патона НАН Украины. 03150, г. Киев, ул. Казимира Малевича, 11. E-mail: office@paton.kiev.ua Рассмотрены основные показатели, характеризующие пожаро- и взрывоопасность продуктов измельчения ферросплавов, применяющихся в электродной технологии. Отмечено влияние типа измельчителя на поведение порошков ферросплавов и приведена сравнительная оценка промышленных установок, используемых в электродном производстве. Сделан вывод о необходимости регулярной аттестации каждой конкретной технологии измельчения ферросплавов. Библиогр. 11, табл. 4, рис. 3.
\end{abstract}

Ключевые слова: сварочное производство, пожсро- и взрывоопасность, электродная технология, измельчение ферросплавов, качество изготовления, аттестаиия технологии

Общие сведения о взрывоопасности металлических порошков. Измельчение, грохочение и транспорт продуктов измельчения сопровождается образованием взрывоопасных аэровзвесей и горючих отложений. Их воспламенение и взрывы внутри размольного, смесительного оборудования, в пневмотранспортных, аспирационных системах, вентиляторах и рукавных фильтрах неоднократно приводило к разрушениям, травматизму и гибели персонала. Воспламенения и взрывы вызывались термическими источниками, а также локальными загораниями, спровоцированными разогревом от механического воздействия или искрением трибоэлектрической природы.

В процессе развития взрыва, как правило, участвует пыль, взвихренная с поверхности оборудования и строительных конструкций, а также внутри вентиляционных систем.

Куски материала в начальной стадии измельчения разрушаются под комбинированным действием раздавливания и удара, а в стадии тонкого измельчения - ударом, комбинированным с истиранием. Общая энергия на измельчение $E_{\mathrm{dis}}$ тратится на упругую и пластическую деформацию зерен $a_{\text {def }} \Delta V$, на нагрев $Q$, а также разрушение частиц с образованием новой поверхности $s \Delta S$ :

$$
E_{\mathrm{dis}}=a_{\mathrm{def}} \Delta V+s \Delta S+Q
$$

где $a_{\mathrm{def}}-$ работа упругой и пластической деформации на единицу объема твердого тела; $s-$ удельная поверхностная энергия; $\Delta V$ - деформированная часть объема измельчаемого материала; $\Delta S$ - прирост поверхности материала вследствие процесса измельчения.

Прирост поверхности при крупном дроблении незначителен и расход энергии на разруше-

\footnotetext{
*Ретроспективный обзор по материалам публикаций в малотиражных изданиях и источниках несварочного профиля.
}

ние считают пропорциональным объему разрушаемого тела. При тонком измельчении преобладает расход энергии на прирост вновь образующейся поверхности. Соотношение составляющих расходов энергии на измельчение зависит от вида помольного оборудования, а также от мельничного гарнитура.

Потенциальная пожаровзрывоопасность процесса измельчения ферросплава зависит от его физико-химических свойств, а также типа и режимов работы измельчительного оборудования.

Ферросплавы различаются по размалываемости, поэтому порошки разных ферросплавов, полученные с использованием одного и того же измельчителя, различаются и по дисперсности, и по пожаровзрывоопасности. То же можно сказать и о порошках одного и того же ферросплава, полученных с применением различных измельчителей.

Пожаровзрывобезопасность технологии измельчения ферросплавов оценивается по методике, которая предусматривает лабораторную и производственную стадию [1].

На лабораторной стадии определяют химический состав, дисперсность, кинетические показатели окисления порошков, состояние поверхности частиц, а также характеристики горючести и взрываемости, прежде всего выделенных из них наиболее активных пылевидных фракций.

В ходе производственной стадии тестируются порошки ферросплавов для электродных покрытий, получаемые в промышленных условиях на разных измельчительных установках. Исследуются также воспламеняемость и взрываемость порошков, их пылевидных фракций (размером мельче 50 мкм), пробы которых отбирают из аспирируемого газа (воздуха) аспирационных систем и из отложений пыли на строительных конструкциях и технологическом оборудовании. 
Чтобы охарактеризовать пожаровзрывоопасность продуктов измельчения, используются следующие показатели [2-5].

Кинетические параметры окисления порошка в предвоспламенительный период нагрева: температура начала экзотермического процесса $T_{\text {нэ }}$ и скорость окисления $V_{\text {ок }}$.

Температура самовоспламенения - наименьшая температура окружающей среды, при которой наблюдается самовозгорание пробы в слое и во взвешенном состоянии $\left(T_{\text {сз }}, T_{\text {св }},{ }^{\circ} \mathrm{C}\right)$. Этот показатель находится путем введения определенной массы вещества в сосуд, нагреваемый до ступенчато поднимающейся температуры, и определения минимального ее значения, при котором происходит самовоспламенение.

Нижний концентрационный предел воспламе-

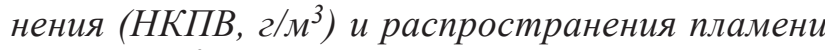
$\left(H К П Р\right.$, г/м $\left.{ }^{3}\right)$ - минимальное содержание горючего вещества в однородной смеси с окислительной средой, при котором возможно воспламенение и распространение возникшего пламени по смеси на любое расстояние от источника зажигания.

Максимально безопасное содержание кислорода в газовой среде, при котором происходит возгорание вещества и распространение пламени (MBCK, \%).

Температура воспламенения аэровзвеси минимальная температура внешнего источника (обычно, нагретой поверхности), при которой воспламеняется аэровзвесь $\left(T_{\mathrm{B}},{ }^{\circ} \mathrm{C}\right)$.

При испытании аэровзвесь определенной концентрации приводится в контакт с нагретой поверхностью. Для каждой концентрации определяется минимальная температура воспламенения, а затем наименьшее из этих значений при различных концентрациях принимается за температуру воспламенения.

Максимальное давление взрыва $P_{\text {макс }}$ МПа, которое представляет собой наибольшее избыточное давление, возникающее при так называемом дефлаграционном, т. е гомогенном, сгорании пылевоздушной смеси в замкнутом сосуде при начальном атмосферном давлении смеси 101,3 кПа. Для определения $P_{\text {макс }}$ пылевоздушная смесь заданного состава зажигается в объеме реакционного сосуда и регистрируется избыточное давление, развивающееся при воспламенении горючей смеси. Изменяя концентрацию горючего в смеси, из полученных результатов выбирают максимальное значение.

Скорость нарастания давления взрыва $V_{\max }$, $\mathrm{MПа} \cdot \mathrm{c}^{-1}$ — производная давления взрыва по времени на восходящем участке зависимости давления взрыва горючей смеси от времени. Сущность метода ее оценки - экспериментальное определение максимального давления взрыва горючей смеси в замкнутом сосуде, построение графика изменения давления взрыва во времени и расчет средней и максимальной скорости по известным формулам [3].

При категорировании производственных измельчительных установок учитываются также требования ПУЭ7 [6].

Сравнение кинетических параметров окисления ферросплавов. Ферромарганец ФМн 92 , ферротитан ФТи 30 и ферросилиций ФСи 45, используемые в качестве раскислителей наплавленного металла, относятся к сплавам с низкой энергией активации. Склонность к окислению их порошков в предвоспламенительном периоде нагрева (от 300 до 600, 700 и $1000{ }^{\circ} \mathrm{C}$, соответственно) оценивается по значениям $T_{\text {нэ }}$ и $V_{\text {ок}}$, найденных методом ДТА. Исследовали фракции с размером частиц 0..40 мкм, выделенные просеиванием порошков, полученных дроблением и виброизмельчением на лабораторных установках. Скорость нагрева навески в ДТА определениях составляла $10^{\circ} \mathrm{C} \cdot$ мин $^{-1}$. Скорость окисления определяли путем графического дифференцирования ДТА- и ДТГ-диаграмм при заданной температуре нагрева материала.

Результаты определения $T_{\text {нэ }}$ представлены в табл. 1, а зависимость скорости их окисления от температуры - на рис. 1 .

Из приведенных данных следует, что исследованные ферросплавы различаются по стойкости против окисления в период предвоспламенительного нагрева. Процесс окисления ферромарганца, самого активного из испытанных ферросплавов, начинается при самой низкой температуре. Наиболее стоек против окисления ферросилиций. Ферротитан занимает промежуточное положение. Характерно, что порошки ферромарганца и ферротитана, полученные виброизмельчением, активнее порошков, измельченных дроблением. В то же время способы измельчения ферросилиция не влияют на значения температур начала экзотермической реакции.

Таблица 1. Значения температуры начала экзотермической реакции $T_{\text {нэ }}$ порошков ферросплавов фракции $0 . .40$ мкм [1]

\begin{tabular}{|c|c|c|}
\hline \multirow{2}{*}{ Ферросплав } & Способ измельчения & $T_{\text {нэ}}{ }^{\circ} \mathrm{C}$ \\
\hline \multirow{2}{*}{ Ферромарганец } & Дробление & 200 \\
\hline \multirow{2}{*}{ Ферротитан } & Вибропомол & 140 \\
\hline \multirow{2}{*}{ Ферросилиций } & Дробление & 220 \\
\cline { 2 - 3 } & Вибропомол & 180 \\
\cline { 2 - 3 } & Дробление & 450 \\
\hline
\end{tabular}


С повышением температуры скорость окисления возрастает. При этом для порошков ферромарганца настолько интенсивно, что при достижении температуры воспламенения дробленые частицы становятся активнее, чем полученные виброизмельчением. Скорость окисления частиц ферротитана возрастает с повышением температуры в меньшей мере, а частиц ферросилиция еще медленнее. Причем их пылевидные частицы сохраняют активность более низкую, чем их виброизмельченные аналоги, на протяжении всего предвоспламенительного периода.

Наряду с порошками, приготовленными в лабораторных условиях, в МИСиС [1] исследовали пробы, отобранные при измельчении ферросплавов на промышленных вибрационных мельницах PALLA. Исследовали фракции с размером частиц $0 \ldots 50$ и $0 \ldots 100$ мкм. Результаты исследований порошков ферромарганца приведены на рис. 2. Они согласуются с изложенными выше данными, характеризующими кинетику окисления пылевидных частиц этого ферросплава, которые получены при использовании измельчителей лабораторного типа.

Действительно, крупнодисперсная проба, как и лабораторный ее аналог, менее активна, поэтому начинает ощутимо окисляться при более высокой температуре, чем мелкодисперсная. С повышением температуры скорость ее окисления нарастает круче.

Сравнивая рис. 1 и 2, видим, что вызванное нагревом повышение скорости окисления частиц размером $0 \ldots 40$ мкм, выделенных из порошков ферромарганца, дробленных в лаборатории, такое же, как и частиц с размерами $0 \ldots 50$ мкм, выделенных из порошка, полученного на промышленной мельнице PALLA. Фракции с размером частиц $0 \ldots 100$ и $0 . .50$ мкм из порошков, полученных на мельнице PALLA, по окислительной способности качественно соотносятся друг с другом так, как и одинаковые размером частицы, которые выделены из порошков, полученных дроблением и,

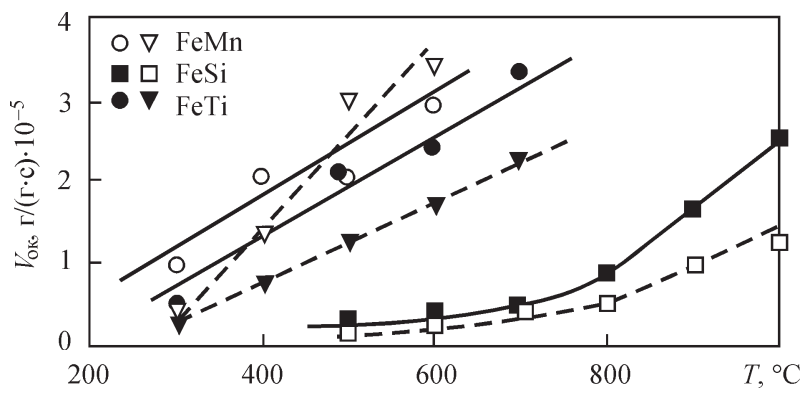

Рис. 1. Влияние температуры на скорость окисления в воздушной среде частиц ферросплавов размером 0..40 мкм, высеянных из порошков, полученных вибропомолом (сплошная кривая) и дроблением (штриховая) [1]

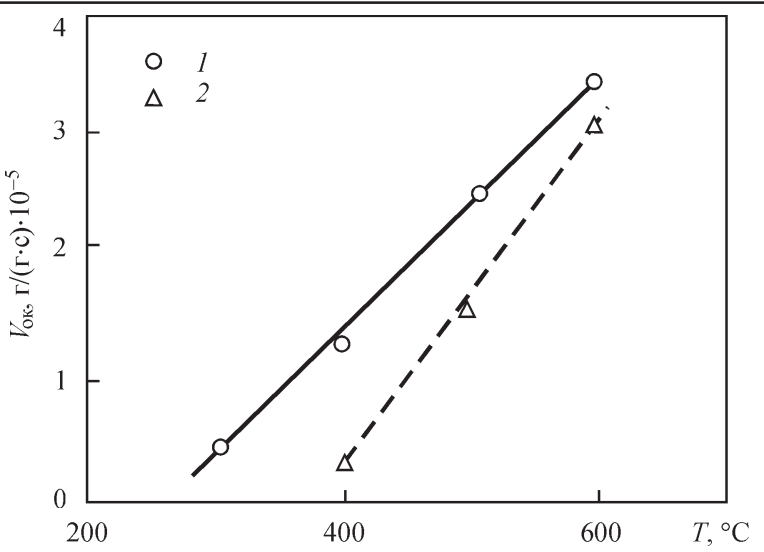

Рис. 2. Влияние температуры на скорость окисления частиц ферромарганца размером $0 \ldots 50$ мкм (1) и $0 \ldots 100$ мкм (2), высеянных из порошков, полученных помолом в мельнице PALLA [1]

соответственно, вибропомолом на лабораторных установках.

По характеру изменения взаимного положения и угла наклона сопоставляемых кривых относительно температурной шкалы может показаться, что размер частиц больше влияет на их окислительную способность, чем активирование их поверхности виброизмельчением, которое должно было бы иметь место.

Поскольку сопоставляемые ферросплавы различаются по плотности, скорость окисления порошков следовало бы, по нашему мнению, нормировать по удельной объемной поверхности частиц, а не по массе пробы.

Нормативные характеристики пожаровзрывоопасности ферросплавов, установленные в лабораторных условиях. Значения показателей пирофорности и взрываемости порошков ферромарганца, ферросилиция и ферротитана приведены по данным ИПМ НАН Украины в табл. 2. Для сравнения в нее включены также показатели порошков металлического марганца и кремния.

Зерновые характеристики использованных порошков ферромарганца и ферротитана сопоставляются на рис. 3.

Принятая в таблице и на рис. 2 индексация образцов: 1 - полидисперсные порошки исследованных ферросплавов; 2 - фракции с размером частиц мельче 50 мкм, высеянные из полидисперсных порошков; 3 - отложения пыли в воздуховоде; $d_{\text {ср }}$ - средневзвешенный диаметр частиц.

Приведенные данные показывают, что наибольшей стойкостью против воспламенения и взрывов характеризуются порошки ферросилиция. Они не воспламеняются ни тепловым, ни пиротехническим источником зажигания, ни в слое, ни в состоянии аэровзвеси.

Порошки ферромарганца и ферротитана в слое характеризуются примерно одинаковыми значе- 
Таблица 2. Показатели пирофорности и взрываемости порошков ферросплавов, используемых в технологии производства электродов [7]

\begin{tabular}{|c|c|c|c|c|c|c|c|c|}
\hline \multirow{2}{*}{ Материал } & \multicolumn{3}{|c|}{ Порошок в слое } & \multicolumn{5}{|c|}{ Аэровзвесь } \\
\hline & $\begin{array}{l}\text { Доля фрак- } \\
\text { ции }-005, \%\end{array}$ & $T_{\mathrm{c} 3},{ }^{\circ} \mathrm{C}$ & $T_{3},{ }^{\circ} \mathrm{C}$ & $T_{\mathrm{B}},{ }^{\circ} \mathrm{C}$ & $\begin{array}{l}\text { НКПВ, } \\
\Gamma / \mathrm{M}^{3}\end{array}$ & $\begin{array}{l}P_{\text {мakc, }} \\
\text { МПа }\end{array}$ & $\begin{array}{l}V_{\text {макс, }} \\
\mathrm{M \Pi а} / \mathrm{c}\end{array}$ & $\begin{array}{l}\text { МBCK, } \\
\text { об } \%\end{array}$ \\
\hline \multirow{3}{*}{ Ферромарганец, ФМн-92 } & $12,5^{1}$ & - & - & - & 260 & 0,15 & 3,0 & 12,3 \\
\hline & $100,0^{2}$ & - & 550 & - & 76 & 0,32 & 5,0 & 7,8 \\
\hline & $100,0^{3}$ & - & - & - & 74 & 0,38 & 20,0 & - \\
\hline Ферросилиций, Фс-45 & $\begin{array}{c}17,0^{1} \\
100,0^{2}\end{array}$ & \multicolumn{7}{|c|}{$\begin{array}{c}\left.\text { Не воспламеняется тепловым (до } 1100^{\circ} \mathrm{C}\right) \text { и пиротехническим источником } \\
\text { зажигания (температура горения около } 2500^{\circ} \mathrm{C} \text { ) }\end{array}$} \\
\hline \multirow{3}{*}{ Ферротитан, Фт-30 } & $14,5^{1}$ & - & - & - & 430 & 0,10 & 0,9 & 15,8 \\
\hline & $95,0^{2}$ & 400 & 530 & 370 & 90 & 0,37 & 8,0 & 10,0 \\
\hline & $100,0^{3}$ & - & - & - & 82 & 0,36 & 12,0 & 12,0 \\
\hline \multicolumn{2}{|c|}{ Марганец метал., $d_{\text {ср }}=44$ мкм } & 240 & 450 & - & 130 & 0,33 & 3,0 & - \\
\hline \multicolumn{2}{|c|}{ Кремний метал., $d_{\text {ср }}=74$ мкм } & 790 & 700 & 55 & 100 & 5,80 & 8,4 & 11,0 \\
\hline
\end{tabular}

ниями $T_{3}$. Однако в состоянии аэровзвеси они существенно различаются. Так, с увеличением доли мелких частиц от 15 до $100 \%$, для порошка ферротитана значения НКПВ (изначально примерно в 2 раза большие, чем у ферромарганца), уменьшаются почти в 5 раз, а у ферромарганца - лишь в 3 раза. При этом значение МВСК сравниваемых объектов понижается лишь в 1,5 раза.

Давление взрыва аэровзвеси порошков ферротитана и ферромарганца и особенно скорость нарастания давления при взрыве изменяется при таком же повышении степени дисперсности в значительно большей мере. Так, значение $P_{\text {макс }}$ сравниваемых ферросплавов в состоянии аэровзвеси возрастает в 2,5 ...3,0 раза. Аналогично возрастает значение $V_{\text {макс }}$ аэровзвеси ферромарганца (от 3 до $5 \mathrm{MПа} / \mathrm{c})$. В то же время $V_{\text {макс }}$ аэровзвеси ферроти-

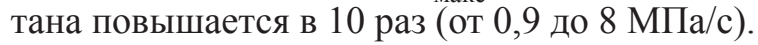

Особо опасна с точки зрения нарастания показателя $V_{\text {макс }}$ роль пылевидных частиц в составе отложений, образцы которых для испытаний отбирали в воздуховоде. Как следует из табл. 2, зна-

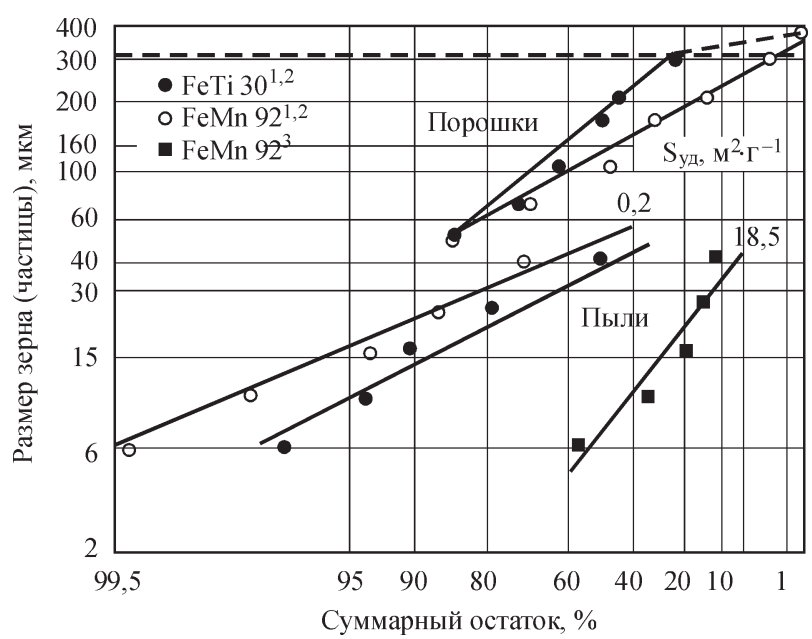

Рис. 3. Зерновые составы порошков ферромарганца, ферротитана (1), отложений пыли ферромарганца в воздуховодах измельчительной установки (2) и пылевидных фракций, высеянных из порошков (3) ферромарганца и ферротитана [7]

чения $V_{\text {макс }}$ аэровзвесей отложений в 4 раза, а ферротитана - в 1,5 раза выше, чем у аэровзвесей подситовых фракций полидисперсных порошков этих ферросплавов.

Влияние типа измельчителя на пожаровзрывоопасность порошков ферросплавов. В работах $[1,8]$ рассмотрена пожаровзрывоопасность порошков, полученных диспергированием ферромарганца, ферросилиция и ферротитана в шаровой мельнице и дезинтеграторе лабораторного типа Д95 с защитной газовой средой. Из изготовленных порошков были отобраны и испытаны две фракции (0..50 и 0..100 мкм). Для сравнения использовали порошок ферромарганца полидисперсного состава, изготовленного в дезинтеграторе Д95. Результаты исследований приведены в табл. 3 .

Приведенные данные показывают, что порошки сравниваемых фракций, полученные измельчением в дезинтеграторе, менее активны, чем в шаровой мельнице. Это объясняется их большей окисленностью из-за более высокой энергетичности процесса измельчения в дезинтеграторе. С повышением доли крупных частиц пожаровзры-

Таблица 3. Влияние вида измельчителя на показатели пожаровзрывоопасности порошков $[1,8]$

\begin{tabular}{|c|c|c|c|c|}
\hline Ферросплав & Фракция, мкм & $\begin{array}{l}\text { НКПВ, } \\
\Gamma / \mathrm{M}^{3}\end{array}$ & $T_{\mathrm{cB}},{ }^{\circ} \mathrm{C}$ & $T_{\mathrm{B}},{ }^{\circ} \mathrm{C}$ \\
\hline \multicolumn{5}{|c|}{ Шаровая мельница лабораторная* } \\
\hline \multirow{2}{*}{ Ферромарганец } & $0 \ldots 50$ & 69 & 370 & 350 \\
\hline & $50 \ldots 100$ & 106 & 540 & 420 \\
\hline Ферросилиций & $0 \ldots 50$ & н.в. & н.в. & н.в. \\
\hline \multirow{2}{*}{ Ферротитан } & $0 \ldots 50$ & н.в. & 590 & 470 \\
\hline & $50 \ldots 100$ & H.B. & 635 & 450 \\
\hline \multicolumn{5}{|c|}{ Лабораторный дезинтегратор Д95* } \\
\hline \multirow{3}{*}{ Ферромарганец } & $0 \ldots 50$ & 190 & 600 & 450 \\
\hline & $50 \ldots 100$ & H.B. & 790 & 550 \\
\hline & Полидисперсная & 280 & 630 & 470 \\
\hline \multirow{2}{*}{ Ферротитан } & $0 \ldots 50$ & н.в. & н.в. & н.в \\
\hline & $50 \ldots 100$ & н.в. & н.в. & H.В \\
\hline
\end{tabular}


воопасность порошков всех испытанных ферросплавов понижается.

По результатам проведенных исследований пылевой фракции, выделенной из порошков ферромарганца, МИСиС [5] ранжировал по значению НКПР использованные лабораторные измельчительные установки следующим образом: КИД (280), дезинтегратор Д35 (190), шаровые мельницы барабанного ШБ (70) и вибрационного типа $\operatorname{BM}\left(50 \Gamma^{\cdot} \mathrm{M}^{-3}\right)$.

Сравнительная оценка промышленных измельчительных установок, используемых в электродном производстве. Общую ситуацию с подготовкой порошков ферросплавов, а также фактические значения показателей их пожаровзрывобезопасности, достигнутые в технологии производства сварочных электродов, можно характеризовать данными, приведенными в работах $[5,8,9]$ :

обширный типаж измельчителей (камерные, проходные, щелевые и вибрационные шаровые и стержневые мельницы, а также роликовые, молотковые и конусные дробилки);

многообразие схем измельчения (с инертной добавкой, в контролируемой газовой или водной среде);

разнообразие способов выделения целевого продукта (грохочение, непрерывный просев совместно с грохочением, сепарирование или центрифугирование);

различные методы межоперационного транспорта готового порошка в технологическом цикле (кюбель, пневмотранспорт и др.).

Простейшим и зачастую вполне надежным техническим приемом предотвращения взрывоопасных ситуаций при тонком измельчении ферросплавов в мельницах периодического действия является загрузка в измельчительную камеру вместе с кусками ферросплава так называемой инертной добавки. Таким продуктом может быть любой из рудоминеральных компонентов покрытия, добавленный в количестве не менее 8 \% массы измельчаемого ферросплава. Даже при этом варианте измельчения для предотвращения взрыва мельница может быть разгерметизирована лишь после предварительной выдержки в течение не менее 15 мин с момента остановки, чтобы гарантировать оседание пыли.

В настоящее время используются в основном мельницы непрерывного действия, обеспечивающие высокую производительность процесса и работающие на проход, с непрерывным просевом измельченного продукта или последующим его грохочением. В этих мельницах измельчение осуществляют преимущественно в защитных газовых средах, а схема и режимы подачи защитного газа (азота или углекислого газа с регламентированной концентрацией кислорода) выбираются с учетом:

химической активности измельчаемого ферросплава;

• их дисперсности в измельченном состоянии;

- конструкции измельчительной установки, в том числе возможностью герметизации кожуха мельницы, а также тракта дальнейшего перемещения готового порошка за его пределами;

- конструкционных особенностей аспирационных отсосов, а также возможностей оптимизации их аэродинамического взаимодействия с защитной средой с целью поддержания парциального давления кислорода в защитной атмосфере измельчителя на заданном уровне, необходимом для образования флегматизирующей оксидной пленки на свежеобразовавшейся поверхности.

В связи с этим характеристики пожаровзрывоопасности промышленных порошков ферросплавов, полученных разными электродоизготовляющими предприятиями, изменяются в достаточно широких пределах (табл. 4). Оценивая их, можно заключить, что порошки, полученные на лабораторных установках, пожаровзрывоопаснее, чем те, которые получены на промышленных установках.

Несмотря на достаточно высокую степень окисленности поверхности частиц они, тем не менее, сохраняют способность гореть и взрываться. Особенно порошки ферромарганца, значения НКПР которых не достигают $1000 \Gamma^{\cdot} \mathrm{M}^{-3}$, а $T_{\text {св }}$ и

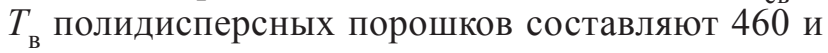
$570{ }^{\circ} \mathrm{C}$, даже если они получены в защитной среде нужной кондиции.

Особенно опасны фракции промышленных порошков мельче 50 мкм. Из табл. 4 следует, что значения НКПР этой фракции составляют $690 \Gamma^{\cdot} \mathrm{M}^{-3}$, а $T_{\text {св }}$ и $T_{\text {в }}-420$ и $510^{\circ} \mathrm{C}$, соответственно. Эффективность инертной добавки невысокая, поскольку она легче измельчается и выходит из камеры щелевой мельницы быстрее, чем частицы порошка ферросплава.

Несколько пассивнее порошки ферротитана такой же фракции, значение НКПР которой превышает $1000^{\circ} \mathrm{C}$, а $T_{\text {св }}$, и $T_{\text {в }}$ составляет 710 и $520^{\circ} \mathrm{C}$, соответственно.

Особую опасность представляют взрывы ферросплавных аэровзвесей, возникающих в размольном оборудовании с участием горючих газов [9].

Водород, выделяющийся из измельчаемого ферросплава, совместно с водородом, ацетиленом, метаном, арсенитами и фосфинами, образующимися в результате взаимодействия сплавов с влагой, оказавшейся по какой-либо причине в мелющей камере, существенно понижают НКПР и 
Таблица 4. Нормативные показатели пожароопасности порошков ферросплавов, полученных в измельчительных установках в производстве электродов

\begin{tabular}{|c|c|c|c|c|c|c|}
\hline Ферросплав (и добавка, \%) & Среда & Выдержка, сутки* & Фракция, мкм & НКПР, $\Gamma^{\cdot} \cdot \mathrm{M}^{-3}$ & $T_{\mathrm{cB}},{ }^{\circ} \mathrm{C}$ & $T_{\mathrm{B}},{ }^{\circ} \mathrm{C}$ \\
\hline \multicolumn{7}{|c|}{ Шаровая мельница щелевая } \\
\hline \multirow{2}{*}{ Ферромарганец (мрамор 15) } & \multirow{4}{*}{ Воздух } & \multirow{4}{*}{3} & $0 \ldots .50$ & 740 & 430 & 620 \\
\hline & & & Полидисперсная & H.В**. & 460 & 760 \\
\hline \multirow{2}{*}{ Ферротитан (мрамор 7) } & & & $0 \ldots 50$ & H.B. & 740 & 520 \\
\hline & & & Полидисперсная & н.в & 930 & 590 \\
\hline \multirow{2}{*}{ Ферромарганец (магнезит 10) } & \multirow{4}{*}{ Азот (92\%) } & \multirow{2}{*}{10} & $0 \ldots 50$ & н.в. & 430 & 760 \\
\hline & & & Полидисперсная & н.в. & 450 & 780 \\
\hline \multirow{2}{*}{ Ферротитан, (мрамор 10) } & & \multirow{2}{*}{-} & $0 \ldots 50$ & 740 & 420 & 600 \\
\hline & & & Полидисперсная & н.в & 850 & 640 \\
\hline \multicolumn{7}{|c|}{ Вибрационная мельница стержневая } \\
\hline \multirow{2}{*}{ Ферромарганец ФМн 92} & \multirow{6}{*}{ Азот $(92 \%)$} & \multirow{6}{*}{7} & $0 \ldots 50$ & 690 & 420 & 510 \\
\hline & & & Полидисперсная & 760 & 460 & 570 \\
\hline \multirow{2}{*}{ Ферросилиций Фс 45} & & & $0 \ldots 50$ & н.в. & 620 & н.в \\
\hline & & & Полидисперсная & н.в. & 790 & н.В \\
\hline \multirow{2}{*}{ Ферротитан ФТи 30} & & & $0 \ldots 50$ & н.в. & 710 & 520 \\
\hline & & & Полидисперсная & н.в. & 870 & 610 \\
\hline
\end{tabular}

* В соответствии с заводской технологией с целью торможения химического взаимодействия с жидким стеклом в обмазке; *** н.в. - значение НКПР превышает $1000 \Gamma^{\circ} \mathrm{M}^{-3}$, а $T_{\text {в }}$ превышает $1000^{\circ} \mathrm{C}$.

МВСК, а также повышают $P_{\text {макс }}$ и $V_{\text {макс }}$ аэровзвесей. Установлено, что на достижение взрывоопасной концентрации водорода, который накапливается в размольной камере вследствие десорбции из частиц ферросплава и их взаимодействия с влагой, может потребоваться не более 1 мин [9]. В таких условиях не достигается нужная эффективность срабатывания аварийных систем газового анализа и своевременная блокировка работы оборудования.

Дополнительную опасность представляют собой микрочастицы (сателлиты), которые, накапливаясь на поверхности более крупных ферросплавных зерен, увеличивают их удельную поверхность. В результате этого значение НКПР полидисперсных порошков может понизиться в 1,5...2,0 раза. С целью предотвращения неблагоприятного влияния этого фактора в размольное оборудование впрыскиваются флегматизирующие добавки склеивающих и обволакивающих жидкостей. Они агломерируют микрочастицы в более крупные агрегаты, покрытые защитной пленкой химически инертной жидкости $[8,10,11]$. На примере порошка ферромарганца, виброизмельченного в течение 3 ч, показано, что долю свободных частиц с размером мельче 40 мкм, можно понизить в нем в 5 раз, а его НКПР — в 3 раза [10].

Изложенные выше результаты показывают, что пожароврывоопасность порошка каждого ферросплава, используемого в электродной технологии, необходимо определять для каждого вида размольного оборудования, режима его работы, места отбора проб, а также использованных технологических приемов предупреждения воспла- менений и взрывов. Другими словами, необходима регулярная аттестация каждой конкретной технологии измельчения ферросплавов подобно тому, как это делается в технологии сварочного производства, с целью регулярного подтверждения качества изготовленной продукции.

Автор признателен О.Д. Нейкову за конструктивные советы и обсуждение материалов.

\section{Список литературы}

1. Толешов А.К. (2009) Метод оценки пожаровзрывоопасности производственных процессов получения порошков металлов и сплавов. Металлург, 6, 30-33.

2. Недин В.В., Нейков О.Д., Алексеев А.Г. и др. (1971) Взрывоопасность промышленных порошков. Киев, Наукова думка.

3. (1990) ГОСТ 12.1.044-89 ССБТ. Пожаровзрывоопасность веществ и материалов. Номенклатура показателей и методы их определения. Москва, Изд-во стандартов.

4. Толешов А.К. (1995) Нормативные характеристики пожаровзрывоопасности порошков ферросплавов, приготовляемых в производстве электродов. Металлург, 4, $19-21$.

5. Бабайцев И.В., Толешов А.К., Державец А.А. (1995) Оценка горючести порошков металлов и сплавов. Там же, 9, 26-27.

6. (2009) Правила улаштування електроустановок. Харків, Форт.

7. Нейков О.Д., Васильева Г.Д., Кузуб А.П. и др. (1971) Исследование взрываемости порошков ферросилиция, ферромарганца, ферротитана, феррохрома, силикокальция и марганца. Предупреждение внезапных взрывов газодисперных систем. Киев, Наукова думка, сс. 36-44.

8. Гридин А.А., Серебрякова В.В., Бабайцев И.В. и др. (1985) Исследование дезинтеграторных процессов диспергирования и активации взрывопожароопасных ферросплавов. Сталь, 11, 36-37.

9. Стрижко Л.С., Бабайцев И.В., Толешов А.К. (1998) Предотвращение взрывов при измельчении ферросплавов. Металлург, 9, 27-28. 
10. Бабайцев И.В., Герусова В.П., Делян В.И. (1983) Пассивация порошков силикокальция. Известия вузов. Черная металлургия, 5, 151-152.

11. Бабайцев И.В., Толешов А.К., Щепелев А.В. (1996) Снижение взрывоопасности порошков ферросплавов в процессе виброизмельчения. Там же, 1, 73-74.

\section{References}

1. Toleshov, A.K. (2009) Method of evaluation of fire and explosion risks of production processes of metal and alloy powders. Metallurg, 6, 30-33 [in Russian].

2. Nedin, V.V., Nejkov, O.D., Alekseev, A.G. et al. (1971) Fire risk of industrial powders. Kiev, Naukova Dumka [in Russian].

3. (1990) GOST 12.1.044-89 SSBT: Fire and explosion risks of substances and materials. Range of blast data and methods of their determination. Moscow, Izd-vo standartov [in Russian].

4. Toleshov, A.K. (1995) Standard characteristics of fire and explosion risks of ferroalloys powder made in electrode production. Metallurg, 4, 19-21 [in Russian].
5. Babajtsev, I.V., Toleshov, A.K., Derzhavets, A.A. (1995) Evaluation of inflammability of powders of metals and alloys. Ibid., 9, 26-27 [in Russian].

6. Rules of arrangement of electric units PUE7 [in Russian].

7. Nejkov, O.D., Vasilieva, G.D., Kuzub, A.P. et al. et al. (1971) Examination of explosibility of ferrosilicon, ferromanganese, ferrotitanium, ferrochrome, silicocalcium and manganese powders. Prevention of sudden explosions of gas-dispersed systems. Kiev, Naukova Dumka, 36-44 [in Russian].

8. Gridin, A.A., Serebryakova, V.V., Babajtsev, I.V. et al. (1985) Study of disintegrator processes of dispersion and activation of explosion and fire hazardous ferroalloys. Stal, 11, 36-37 [in Russian].

9. Strizhko, L.S., Babajtsev, I.V., Toleshov, A.K. (1998) Prevention of explosions in refining of ferroalloys. Metallurg, 9, 27-28 [in Russian].

10. Babajtsev, I.V., Gerusova, V.P., Delyan, V.I. (1983) Passivation of powders of silicocalcium. Izv. Vuzov. Chyorn. Metallurgiya, 5, 151-152 [in Russian].

11. Babajtsev, I.V., Toleshov, A.K., Shchepelev, A.V. (1996) Decrease of explosion risk of ferroalloys powders during vibrogrinding. Ibid., 1, 73-74 [in Russian].

\title{
ФАКТОРИ РИЗИКУ ТА КРИТЕРІЇ ПОЖЕЖО- ТА ВИБУХОНЕБЕЗПЕЧНОСТІ ПРИ ПОДРІБНЕННІ ФЕРОСПЛАВІВ
}

\author{
А.Ю. Марченко
}

IE3 ім. Є.О. Патона НАН України. 03150, м. Київ, вул. Казимира Малевича, 11. E-mail: office@paton.kiev.ua

Розглянуто основні показники, що характеризують пожежо- та вибухонебезпечність продуктів подрібнення феросплавів, що застосовуються в електродній технології. Відзначено вплив типу подрібнювача на поведінку порошків феросплавів та приведена порівняльна оцінка промислових установок, що використовуються в електродному виробництві. Зроблено висновок про необхідність регулярної атестації кожної конкретної технології подрібнення феросплавів. Бібліогр. 11, табл. 4 , рис. 3 .

Ключові слова: зварювальне виробничтво, пожежо- та вибухонебезпечність, електродна технологія, подрібнення феросплавів, якість виготовлення, атестація технологіï.

\section{RISK FACTORS, AND CRITERIA OF FIRE AND EXPLOSION SAFETY AT FERROALLOY GRINDING*}

\author{
A.E. Marchenko
}

E.O. Paton Electric Welding Institute of the NAS of Ukraine.

11 Kazimir Malevich Str., 03150, Kyiv, Ukraine. E-mail: office@paton.kiev.ua

Considered are the main values, characterizing the fire and explosion safety of products of grinding ferroalloys, applied in electrode technology. The effect of grinder type on behaviour of ferroalloy powders is noted, and comparative evaluation of industrial plants used in electrode production, is given. A conclusion is made about the need for regular certification of each specific technology of ferroalloy grinding. 11 Ref., 4 Tabl., 3 Fig.

Keywords: welding production, fire and explosion safety, electrode technology, ferroalloy grinding, manufacturing quality, technology certification

\section{НОВАЯ КНИГА}

Физические процессы при сварке и обработке материалов. Теоретическое исследование, математическое моделирование, вычислительный эксперимент: Сб. статей и докладов под ред. акад. НАН Украины И.В. Кривцуна. - Киев: Международная Ассоциация «Сварка», 2018. - 642 с. 


\section{ВСЕУКРАЇНСЬКИЙ КОНКУРС СТУДЕНТСЬКИХ НАУКОВИХ РОБІТ ЗА НАПРЯМОМ «ЗВАРЮВАННЯ»}

10 квітня 2019 р. в Запорізькому національному технічному університеті (ЗНТУ) відбувся всеукраїнський конкурс студентських наукових робіт за напрямом «зварювання». Традиційно конкурс складався 3 двох етапів. Перший, заочний, етап проводився 3 початку грудня минулого року по березень цього року. На протязі першого етапу виконували рецензування робіт, визначали їх рівень. Кращі наукові студентські роботи рекомендували для доповідей на конкурсі.

Заздалегідь можливим учасникам були направлені запрошення, в яких було наведено умови участі в конкурсі. Для роботи в складі жюрі запрошувались провідні вчені зварювального профілю. Бажання брати участь у конкурсі виявили всі кафедри України, які готовлять спеціалістів зварювального напряму, а також споріднених зварюванню напрямів. Всього з 21 навчального закладу було представлено 78 студентських наукових робіт. Всі роботи були ретельно розглянуті членами конкурсної комісії, а роботи студентів ЗНТУ підлягали зовнішній рецензії. Потім, згідно рецензії, конкурсна комісія оцінила рівень кожної роботи i, таким чином, визначила iï рейтинг. Всього для участі у другому етапі конкурсу, що був представлений як очна конференція, було запрошено студентів-авторів 24 наукових робіт. Безпосередньо 22 автори брали участь у захисті своїх робіт.

Відкрив конференцію проректор з науково-педагогічної роботи і виховання студентів ЗНТУ професор Сергій Тимофійович Ярембаш. 3 вітальним словом до учасників конференції звернувся завідувач кафедри обладнання та технології зварювального виробництва професор Олександр Володимирович Овчинников.

За організацією робота конференції проводилася у двох секціях. Секцією «Технологія та устаткування зварювання» керував професор О.Г. Биковський, а секцією «Відновлення та підвищення зносостійкості деталей і конструкцій» професор С.М. Попова.

Всього на секції «Технологія та устаткування зварювання» було зроблено 7 доповідей, а на секції «Відновлення та підвищення зносостійкості деталей і конструкцій» - 15 .

Кожному студенту, що робив доповідь, учасники конференції давали запитання, за матеріалами окремих доповідей виникали жваві дискусії. Рівень кожної доповіді оцінювався членами жюрі конференції, до складу якого входили провідні вчені як ЗНТУ, так і інших кафедр зварювального напряму.

Згідно виявленого наукового рівня були визначені переможці конкурсу. Диплом І ступеня отримали: О.О. Гайворонський (керівник - ст. викл. Д.М. Голуб, Донбаська державна машинобудівна академія); Ю.С. Патук (керівник - доцент С.М. Ющенко, Чернігівський національний технологічний університет); А.С. Борніков (керівник - доцент О.А. Сливінський, Національний технічний

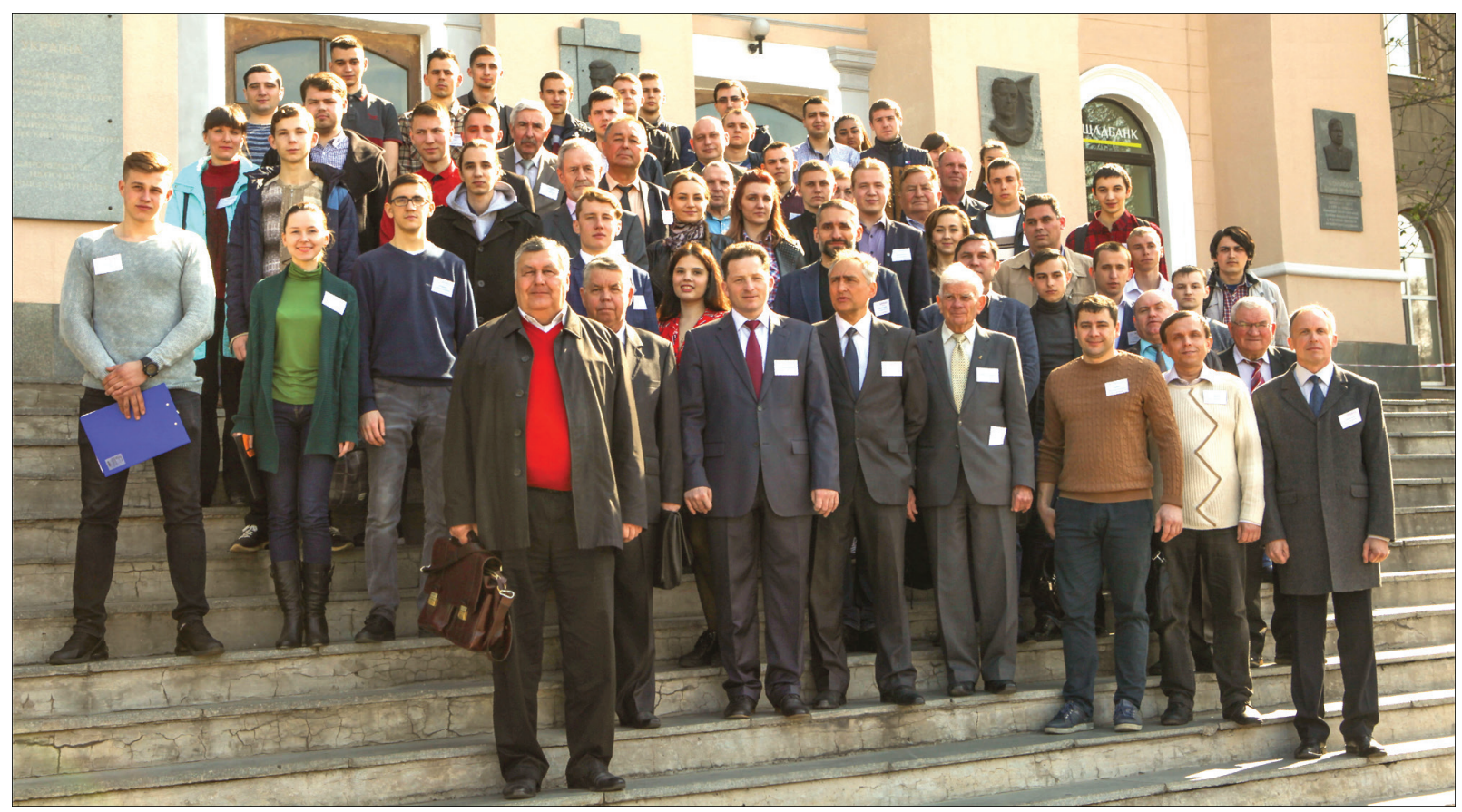

Учасники конкурсу 
університет України «Київський політехнічний інститут» імені Ігоря Сікорського); Р.Ю. Фетісов (керівник - доцент С.П. Бережний, Запорізький національний технічний університет).

Диплом II ступеня отримали: М.M. Биченко (керівник - доцент О.П. Гапонова, Сумський державний університет); С.M. Вінніков (керівник — зав. кафедрою, професор Д.Б. Глушкова, Харківський національний автомобільно-дорожній університет); П.А. Сітніков (керівник - доцент О.В. Крахмальов, НТУ «Харківський політехнічний інститут»); Б.В. Занько (керівник - зав. кафедрою, професор О.С. Калахан, Львівський національний аграрний університет); E.O. Синдецький (керівник - доцент О.Г. Білик, «Приазовський державний технічний університет»); Ю.Р. Михєєв (керівник - професор С.О. Лузан, Харківський національний технічний університет сільського господарства імені Петра Василенка).

Диплом III ступеня отримали: С.О. Кузьма (керівник - доцент М.I. Андрущенко, Запорізький національний технічний університет); O.C. Хоменко (керівник - зав. кафедрою, професор B.І. Савуляк, Вінницький національний технічний університет); Р.А. Нуруллін (керівник - ст. викл. В.М. Ласкін, Національна металургійна академія України); Г.С. Задорожній (керівник професор В.В. Перемітько, Дніпровський державний технічний університет); C.B. Буріков (керівник - доцент В.П. Іванов, ДВНЗ «Приазовський державний технічний університет»); С.А. Захаров (керівник - доцент Ю.С Попіль, НТУУ «Київський політехнічний інститут імені Ігоря Сікорського»); А.В. Шевченко (керівник - доцент М.В. Матвієнко, Херсонська філія «Національного університету кораблебудування ім. адмірала Макарова»); A.B. Малярян (керівник - доцент Д.Д. Марченко, Миколаївський національний аграрний університет); Д.В. Кравченко (керівник - профеcop С.В. Драган, Національний університет кораблебудування ім. адмірала Макарова); I.C. Muненко (керівник - професор В.Д. Макаренко, Полтавський національний технічний університет імені Юрія Кондратюка); Д.І. Ленартович (керівник - професор М.М. Студент, НУ «Львівська політехніка»); Ю.Г. Шамрук (керівник - профеcop Ч.В. Пулька, Тернопільський національний технічний університет імені Івана Пулюя).

Учасники конференції відвідали Музей техніки Богуслаєва і Музей історії технічного прогреcy ЗНТУ.

В цілому рівень організації проведення Всеукраїнського конкурсу студентських наукових робіт за напрямом «Зварювання» у ЗНТУ за оцін-

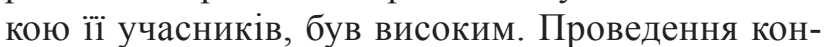
ференції є корисним відносно поглиблення знань студентами і становленню ї як майбутніх висококваліфікованих спеціалістів зварювального профілю.

\section{НАУЧНО-ТЕХНИЧЕСКОЕ СОТРУДНИЧЕСТВО: ИЭС — ТУРБОАТОМ}

15 апреля 2019 г. в Институте электросварки им. Е.О. Патона состоялась встреча директора ИЭС, академика Б.Е. Патона с Генеральным директором АО «Турбоатом» В.Г. Суботиным. Во встрече приняли участие: заместители директора академики С.И. Кучук-Яценко, Л.М. Лобанов, И.В. Кривцун, заведующий отделом А.К. Царюк (ИЭС им. Е.О. Патона) и генеральный конструктор Е.В. Левченко (АО «Турбоатом»).

На встрече было отмечено, что сегодня АО «Турбоатом» совместно с научными академическими институтами создает наукоемкую продукцию, которой может гордиться Украина. Квалифицированный персонал и современное, модернизированное технологическое оборудование позволяет предприятию создавать новые образцы энергомашиностроительной продукции, турбин-

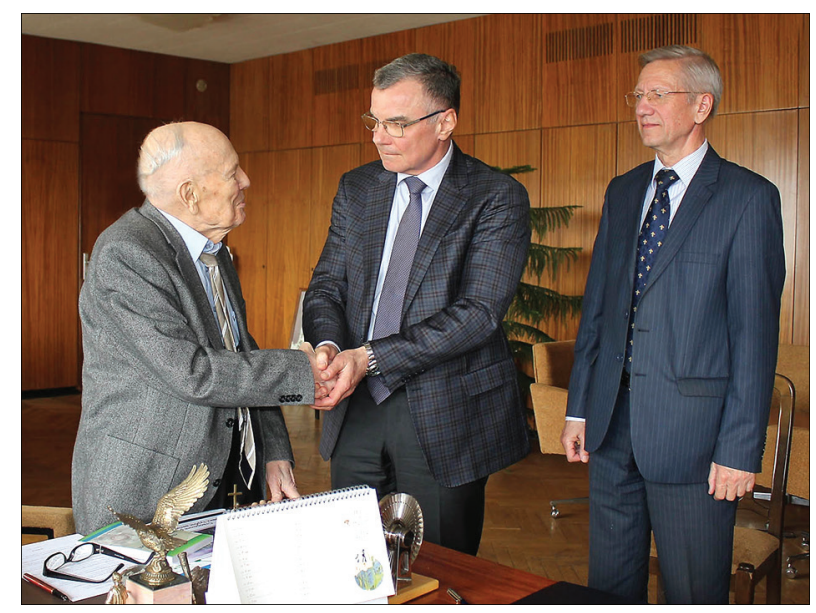

После подписания соглашения. Слева направо: академик Б.Е. Патон, Генеральный директор АО «Турбоатом» В.Г. Суботин и генеральный конструктор Е.В. Левченко 
ное оборудование для АЭС, ТЭС, ГЭС, ГАЭС, которое не уступает лучшим мировым образцам, а зачастую и превосходит их по техническим характеристикам. Среди них известные в мире турбины-«миллионники» для АЭС с реакторами ВВЭР1000 единичной мощностью 1 млн кВт, сварные роторы массой по 200 т для тихоходных турбин большой мощности, крупные роторы с применением композитных материалов, конденсаторы блочно-модульного исполнения с трубными системами из коррозионностойких материалов.

Активизированы совместные усилия ученых и производственников по созданию оборудования по программе импортозамещения. Весомые достижения достигнуты в области гидротурбостроения для ГЭС и ГАЭС.
В модернизацию станочного парка заводского оборудования вложено за последние 10 лет 70 млн дол. США. Модернизировано и переоснащено литейное, сварочное и механообрабатывающее производство.

Отмеченные успехи достигнуты благодаря активному сотрудничеству АО «Турбоатом» с институтами НАН Украины.

В рамках встречи было подписано Соглашение о научно-техническом сотрудничестве между $\mathrm{AO}$ «Турбоатом» и Институтом электросварки им. Е.О. Патона НАНУ, ведущей научной организацией в области сварки, конкретизирующее совместные планы на ближайший период и перспективу.

\section{СЕМИНАР «АВТОМАТИЗАЦИЯ И МЕХАНИЗАЦИЯ СВАРКИ»}

16 мая 2019 г. в Технологическом центре ООО «Фрониус-Украина» (с. Княжичи, Броварского района) состоялся семинар на тему «Автоматизация и механизация сварки». Цель семинара: ознакомить специалистов сварочного производства с новейшими технологиями автоматической сварки компании Fronius (Австрия).

В работе семинара приняли участие свыше 20 специалистов предприятий различного профиля. Программа семинара включала ряд презентаций на темы:

- Системы для автоматизации сварки и наплавки;

- Оборудование для орбитальной сварки;

- Компоненты малой механизации процессов сварки;

- Новая продукция Fronius Automation.

Менеджер по автоматизации В. Полищук в своей презентации рассказал о классификации систем для сварки и наплавки с использованием процессов MAG, MIG, TIG и плазменной сварки. Компаня Fronius на сегодняшний день оснащает выпускаемые системы шланг-пакетами только собственного производства. Системы для автоматизации подразделяются на системы для сварки продольных швов (FLW), кольцевых швов (FCW), мультисварочные универсальные системы (FMW) и системы для наплавки (FOW).

Системы для орбитальной сварки Fronius производит двух типов: закрытого и открытого. Системы комплектуются головками и блоками управления от Fronius. Головки рассчитаны для сварки труб с большим диапазоном по диаметру. Открытый тип используется для сварки труб из черных сталей, закрытый - труб из нержавею- щих сталей, алюминиевых и титановых сплавов. Последние выполнены водоохлаждаемыми. Используются для процессов сварки MIG, MAG, TIG, TIG с присадкой. Системы снабжены устройствами для локальной защиты корня шва (цилиндры поддува), анализаторами контроля атмосферы

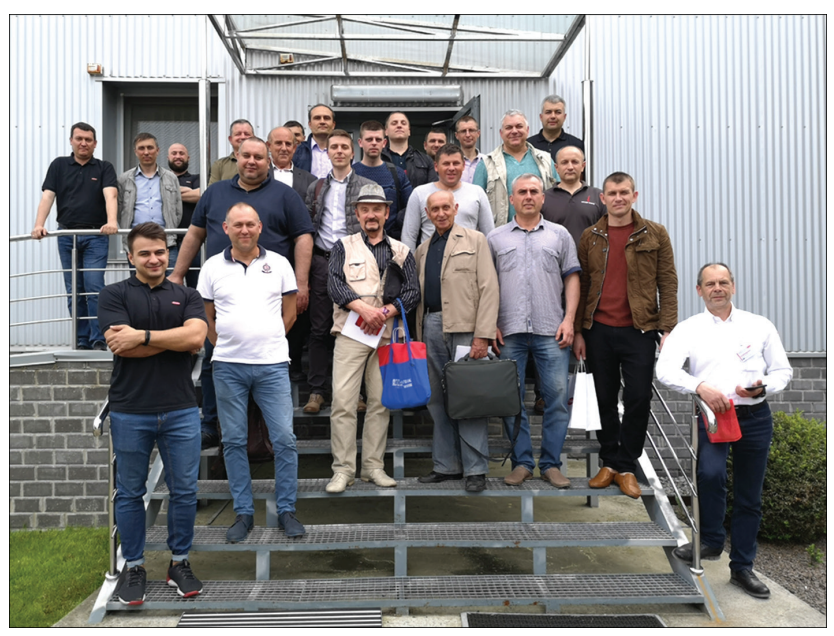

Участники семинара

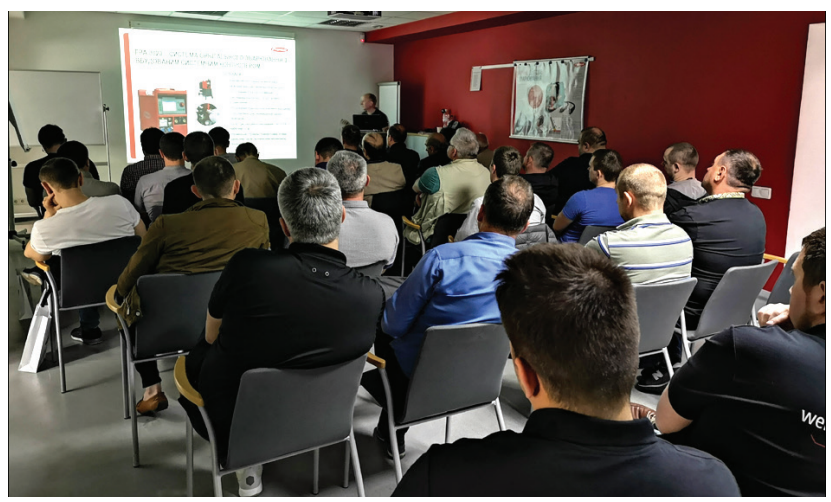

Презентация доклада 


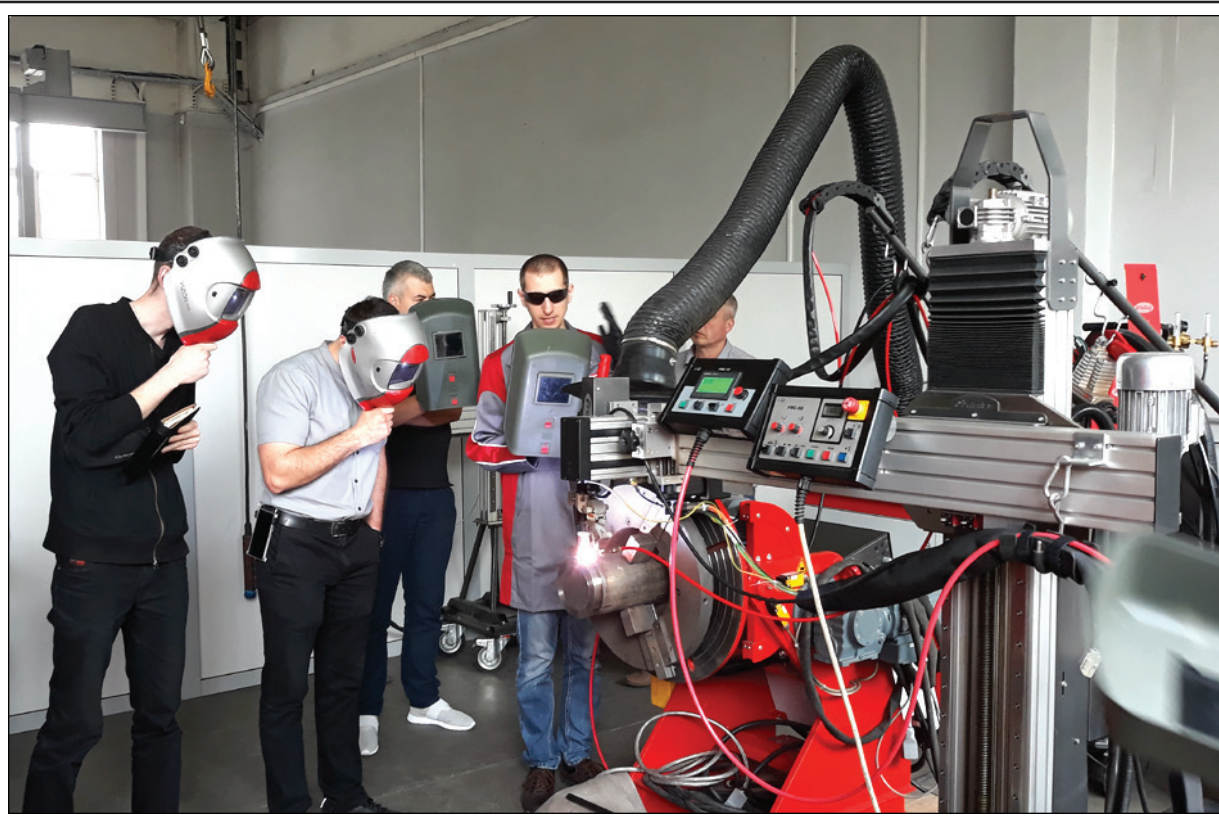

Практическая демонстрация технологий сварки от Fronius

в зоне сварки. Важно обеспечить качественную заточку вольфрамового электрода. Для этой цели используется специализированное оборудование (машинки) с твердосплавным инструментом.

В настоящее время Fronius получил задание и разрабатывает систему автоматизации орбитальной сварки соединений труба-доска и труба-коллектор для энергетической отрасли (с использованием MAG сварки в нижнем и горизонтальном положениях.

В следующей презентации слушателей ознакомили с комплектами малой механизации процессов сварки. Они включали: тележки для механизации сварки продольных швов (FlexTrack, ArcRover, FDV, FTV); поворотные столы FTT/FRT для механизированной сварки кольцевых швов; сварочные головки для позиционирования горелки, опции AVC/OSC; штативы FSB и механизированные колонны FSB для позиционирования сварочной головки; вращатели FPW/FRU для механизации ручной MIG/MAG/TIG сварки кольцевых швов, системы видеонаблюдения.

Далее участники семинара были ознакомлены с новой продукцией Fronius Automation. Наибольший интерес вызвала информации о процессе ArcTIG и оборудовании для ее реализации. По сути это процесс TIG сварки с использованием сжатой дуги. При этом используется охлаждаемая (от специального холодильника) горелка, специальная заточка вольфрамового электрода и стандартный источник питания. В результате достигается возможность стыковой сварки сталей без разделки кромок толщиной 10 мм за один проход.
Fronius в поисках эффективных решений по автоматизации обратил внимание на необходимость автоматизации аддитивной технологии (WAAM), к которой сейчас проявляется повышенный интерес. Работа идет в направлении создания системы, включающей: «проволоку + дугу + аддитивный процесс + источник питания + манипулятор (робот) + сварочную головку + программное обеспечение».

Fronius в настоящее время взаимодействует со многими производителями сварочных роботов (АВВ, КУКА, ФАНУК, КАВАСАКИ и др.). Компания идет по пути создания роботизированных стандартных ячеек. Реализация проектов по автоматизации с применением роботов - новое направление в проектах Fronius.

В заключение участникам семинара были практически продемонстрированы следующие процессы:

- механизированная TIG сварка кольцевого шва на трубе диаметром $150 \times 8$ мм из хромоникелевой стали;

- орбитальная TIG сварка соединения трубаколено диаметром $38 \times 1,5$ мм из хромоникелевой стали;

- механизированная MIG/MAG сварка стыкового шва хромоникелевой стали толщиной 3 мм;

- механизированная MIG/MAG сварка таврового соединения PMC Syncropuls на хромоникелевой стали толщиной 8 мм.

Участники выразили признательность организаторам семинара за теплый прием, содержательные сообщения и практические демонстрации. 


\section{МІЖНАРОДНА КОНФЕРЕНЦІЯ «ІННОВАЦІЙНІ ТЕХНОЛОГІЇ ТА ІНЖИНІРИНГ У ЗВАРЮВАННІ І СПОРІДНЕНИХ ПРОЦЕСАХ - POLYWELD 2019»}

У період 23-24 травня 2019 р. у Національному технічному університеті України «Київський політехнічний інститут ім. Ігоря Сікорського» вдруге проходила Міжнародна конференція «Інноваційні технології та інжиніринг у зварюванні і споріднених процесах - PolyWeld 2019». Організатором заходу стала кафедра зварювального виробництва зварювального факультету КПІ ім. Ігоря Сікорського. На конференції заслухані та обговорені 44 доповіді провідних вчених-фахівців 3 напряму зварювання. Зокрема були представлені доповіді від IE3 ім. Є.О. Патона НАН України, Дослідницької мережі Лукасевич - Інститут зварювання, (м. Глівіце, Польща), Білоруського державного університету, Фізико-технічного інституту НАН Республіки Білорусь, Інституту тепло- та масообміну ім. О.В. Ликова НАН Республіки Білорусь, Китайсько-українського інституту зварювання

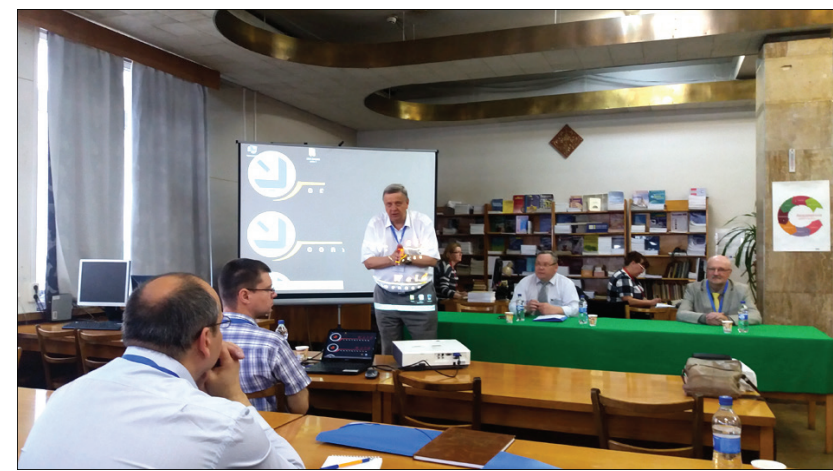

Відкриває конференцію академік НАНУ І.В. Крівцун ім. Є.О. Патона, Школи матеріалознавства та інженерії Шеньянського технологічного університету, Католицького університету Льовена (Бельгія), Інституту проблем матеріалознавства НАН України ім. I.М. Францевича, ЦНДІ ОВТ ЗСУ, НУОУ ім. Івана Черняховського, Національного університету ім. Тараса Шевченка, Національного університету кораблебудування ім. адмірала Макарова, Національного університету «Запорізька політехніка», ДП НВКГ «Зоря»-«Машпроект», ТОВ «Тріада-зварювання», ТОВ «Плазер» та КПІ ім. Ігоря Сікорського.

Цьогорічна конференція присвячена 125-річчю 3 дня народження видатного вченого - фахівця зі зварювання, академіка Хрєнова Костянтина Костянтиновича. Сучасні тенденції у зварюванні та різносторонні наукові інтереси К.К. Хрєнова визначили спрямованість

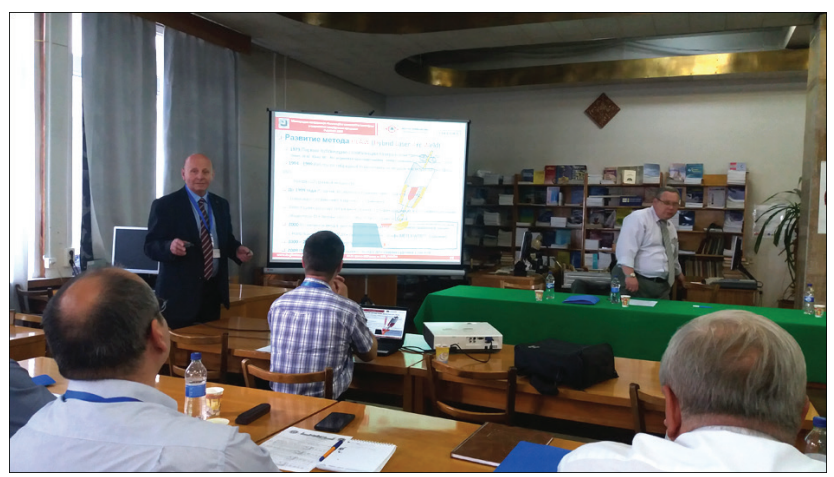

Під час виступу $\mathrm{C}$. Турика

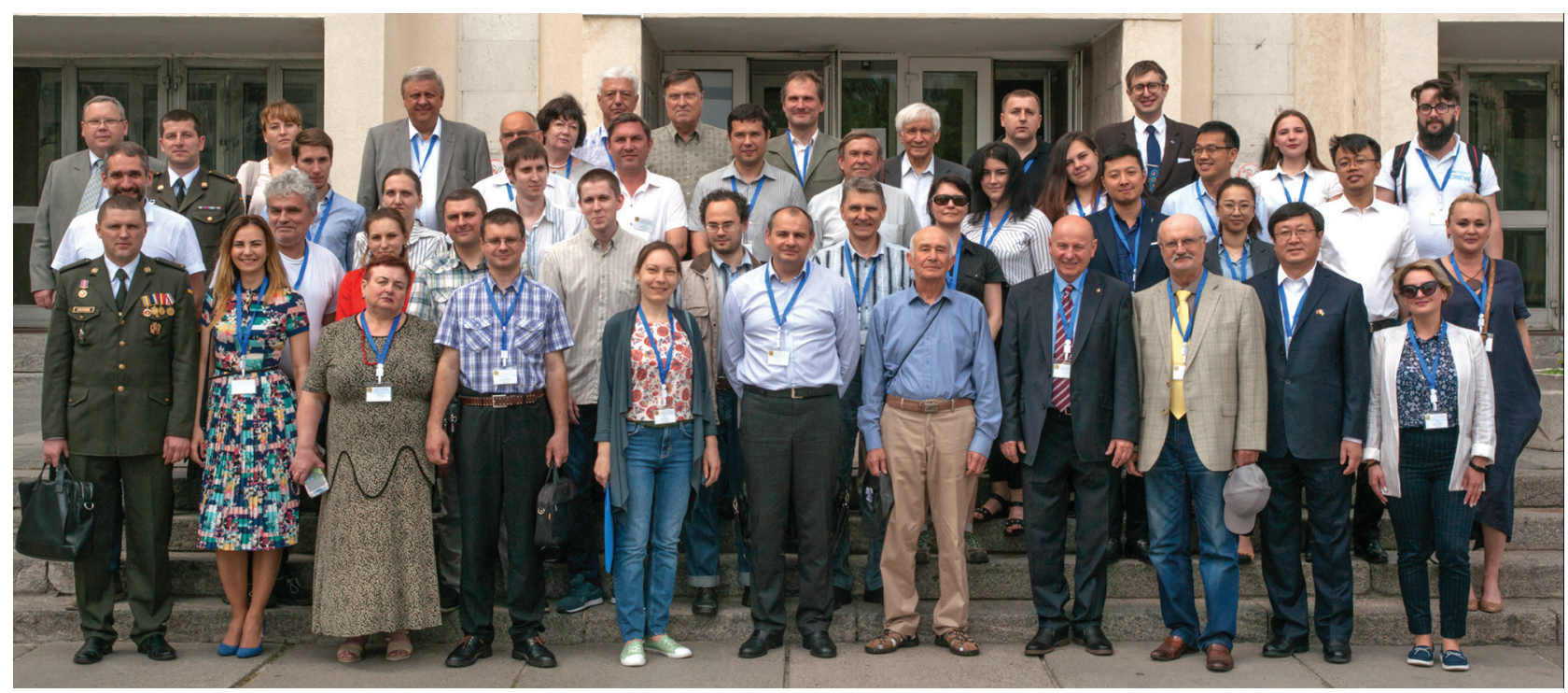

Учасники Міжнародної конференції 
доповідей конференції. Були обговорені актуальні проблеми зварювання та суміжних технологій, у тому числі гібридних лазерно-дугових процесів зварювання, дисперсійного модифікування металу зварних швів, напружено-деформованого стану зварних та паяних з'єднань, технологій плазмової обробки металів, застосування наноматеріалів у зварюванні та нанесенні покриттів, особливостей руйнування об'єктів при високошвидкісному динамічному навантаженні, електронно-променевого зварювання, створення нових зварювальних матеріалів, застосу- вання математичного моделювання для аналізу фізико-хімічних і деформаційних процесів при зварюванні та споріднених технологіях, сучасних методів контролю якості виробів, санітарно-гігієнічної безпеки персоналу, адитивних технологій зварювання, технологій нанесення покриттів, тенденцій розвитку стандартизації в зварюванні та ін.

В ході обговорень учасники конференції визначили напрями подальшого розвитку досліджень за темами доповідей.

\section{МЕЖДУНАРОДНАЯ КОНФЕРЕНЦИЯ «МАТЕРИАЛЫ ДЛЯ СВАРКИ, НАПЛАВКИ, НАНЕСЕНИЯ ПОКРЫТИЙ И 3D-ТЕХНОЛОГИЙ»}

4-5 июня 2019 г. в Киеве в Институте электросварки им. Е.О. Патона прошла Международная научно-техническая конференция «Материалы для сварки, наплавки, нанесения защитных покрытий и $3 \mathrm{D}$-технологий», организованная ИЭС им. Е.О. Патона, международными ассоциациями «Сварка», «Электрод» и Обществом сварщиков Украины. К началу работы конференции были изданы труды в виде специального выпуска журнала «Автоматическая сварка», №6, 2019 г.

В конференции приняли участие ученые, преподаватели и инженерно-технические специалисты НИИ, вузов, промышленных и коммерческих предприятий, представители ассоциаций из ряда городов Украины, а также зарубежные участники из Польши, Германии, Франции. Bceго свыше 60 человек.

В перечень организаций и компаний, чьи специалисты приняли участие в конференции, вошли: ИЭС им. Е.О. Патона, ОЗСО ИЭС им. Е.О. Патона, ООО «ТМ Велтек», ООО «Сумы-Электрод», ООО «ВИТАПОЛИС», НТУУ «Киевский политехнический институт», Днепропетровский национальный университет, Институт черной металлургии НАН Украины, ГП «Ивченко-Прогресс», ООО «ПЛАН-Т», ООО «Аддитивные лазерные технологии Украины», ООО «Технологии высоких энергий», ООО «Зираст-Днепр», Днепровский ГТУ, ООО «ВАНТ», Институт сварки в Гливицах (Польша), компании «Dr. Rosert RCT» (Германия), «Welding Alloys Group» (Франция) и другие.

На открытии конференции с приветствием выступил заместитель директора ИЭС им. Е.О. Патона по науке академик И.В. Кривцун. Он передал слова приветствия участникам конференции от имени академика Б.Е. Патона, кратко охарактеризовал основные тенденции на мировом рынке сварочных материалов и пожелал успешной и плодотворной работы конференции. Особо подчеркнута важность встреч и обсуждений специалистов в области сварочных материалов, помогающих повышать эффективность сварочного производства.

На конференции в пленарном режиме было заслушано 16 докладов по ряду актуальных для сварочного производства тем. Не останавливаясь подробно на каждом из них (как отмечалось, доклады вошли в выпуск журнала «Автоматическая сварка», №6, 2019 г.), отметим лишь те, которые вызвали наибольший интерес и по которым состоялась оживленная дискуссия. Так, в докладе А.А. Мазура (ИЭС им. Е.О. Патона) «Состояние и перспективы мирового рынка сварочных материалов» отмечено, что сварка в обозримой перспективе является базовой технологией во многих отраслях промышленности и строительства. Для промышленно развитых стран характерна достаточно устойчивая динамика развития

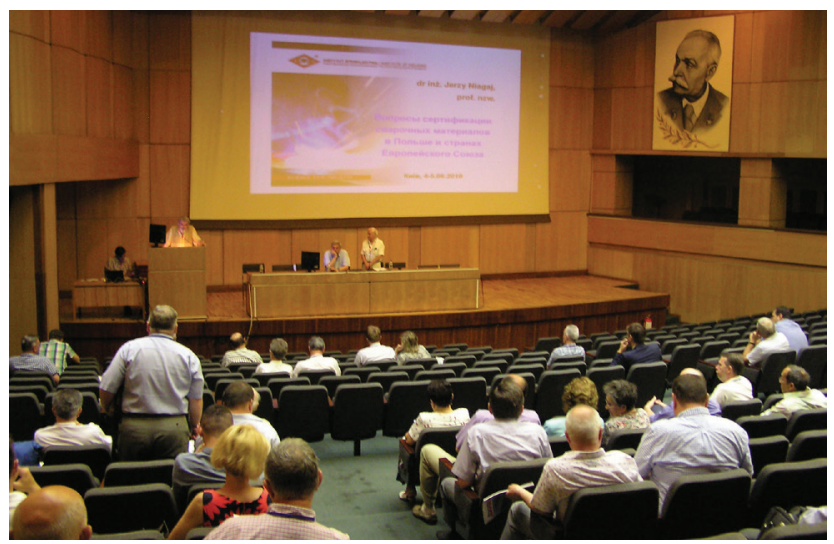

Дискуссия во время доклада А.А. Мазура 


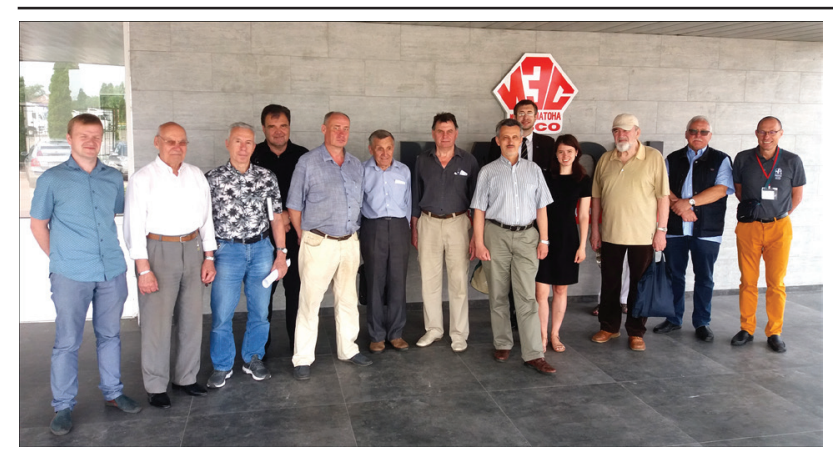

Во время посещения ОЗСО ИЭС им. Е.О. Патона

сварочного производства и сварочного рынка, которая определяется стабильным ростом потребления конструкционных материалов и расширением их сортамента, а также появлением на сварочном рынке новых прогрессивных материалов, технологий и оборудования для сварки и связанных с ней процессов.

Р. Росерт (Германия) в докладе «Сварка и наплавка под флюсом высоколегированных сталей порошковыми проволоками» подробно остановился на нескольких примерах реализованных проектов по изготовлению уникального сварочного оборудования. Отмеченные технологии сварки и наплавки сегодня эффективно используются для сварки всех классов высоколегированных сталей и сплавов, для наплавки сплавов на кобальтовой основе.

Е. Нагай (Польша) в докладе «Вопросы сертификации сварочных материалов в Польше и странах Европейского Союза» остановился на алгоритме действий любой компании, ставившей своей целью войти на европейский рынок. Он подробно осветил шаги, которые прошла Польша на пути экономического развития, позволившие стать ей равноправным членом ЕС.

Большой интерес вызвал доклад А.А. Кононенко (Днепропетровский национальный университет) «Исследование условий глубокого проплавления при изготовлении образцов из жаропрочного сплава Juconel 718 методом выборочного лазерного плавления». Этот метод (Selictive Laser Melting) позволяет изготавливать сложнопрофильные изделия по компьютерной модели практически из любых металлических порошков.

Во время конференции была проведена выставка производителей сварочных материалов, в которой приняли участие ИЭС им. Е.О. Патона, ОЗСО им. Е.О. Патона, ООО «Сумы-Электрод», ООО «ВИТАПОЛИС», ООО «ВЕЛТЕК», ООО «ПЛАН-Т».

Во время работы конференции и выставки состоялся ряд двухсторонних переговоров, направленных на кооперацию и дальнейшее сотрудничество, выполнению совместных проектов.

Во второй день конференции ее участники посетили Опытный завод сварочного оборудования им. Е.О. Патона.

А.Т. Зельниченко, В.Н. Липодаев

\section{В.В. ГОЛОВКО -75}

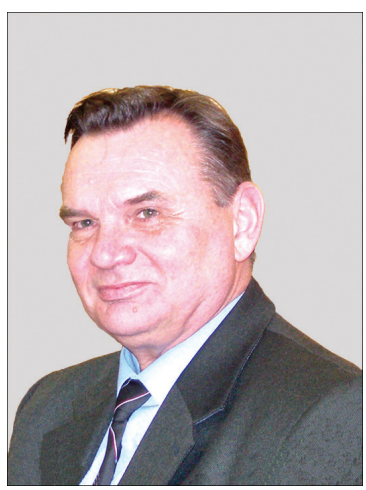

2 июля исполнилось 75 лет Виктору Владимировичу Головко, заведующему отделом исследований физико-химических процессов в сварочной дуге ИЭС им. Е.О. Патона НАН Украины, доктору технических наук, известному ученому и специалисту в области металлургии сварки и сварочных материалов.

В.В. Головко родился 2 июля 1944 г. в г. Йошкар-Ола Марийской АССР. В 1971 г. после окончания Киевского политехнического института по специальности «Технология и оборудование сварочного производства» был направлен на работу в Институт электросварки им. Е. О. Патона АН Украины, где прошел путь от инженера до заведующего научным отделом.
На протяжении почти 50 лет работы в институте основными направлениями научной и практической деятельности В. В. Головко являются исследования и разработка агломерованных флюсов, создание технологий для их производства и применения в промышленных условиях, работы в области физического и математического моделирования, численного моделирования процессов взаимодействия расплавленного металла с флюсом при дуговой сварке, исследования влияния окислительного потенциала и состава шлаковых систем на образование и распределение неметаллических включений в металле низколегированных сварных швов, изучение путей снижения сорбции водорода сварочной ванной. В.В. Головко провел фундаментальные исследования влияния морфологии неметаллических включений и микролегирования металла сварных швов на условия формирования микроструктуры и свойства сварных соединений низколегированных сталей повышенной и высокой прочности. Результаты этих исследований легли в основу докторской диссер- 
тации, успешно защищённой в 2006 г. Разработанные им флюсы помогли решить проблемы сварки объектов специального судостроения, производства газопроводных труб большого диаметра, мостовых и других металлоконструкций.

В настоящее время В. В. Головко большое внимание уделяет вопросам моделирования процессов, определяющих химический состав и структуру металла сварных швов, а также разработке системного подхода и расчётных алгоритмов численного прогнозирования образования и роста неметаллических включений в металле шва, изучению возможностей наномодифицирования металла сварных швов за счёт использования тугоплавких дисперсных частиц, созданию расчётной модели для практического прогнозирования формирования неметаллических включений в металле сварного шва. Результаты этих работ вносят существенный вклад в развитие сварочной науки.

В. В. Головко является автором свыше 130 научных работ, 23 авторских свидетельств на изобретения, патентов Украины, США, ФРГ и Швеции.
Много сил и энергии он отдает подготовке молодых квалифицированных научных кадров, осуществляя руководство практикой студентов-выпускников НТУУ КПИ в ИЭС им. Е. О. Патона.

Много внимания В. В. Головко уделяет общественной работе. На протяжении ряда лет он неизменно избирается председателем профкома ИЭС им. Е. О. Патона.

За весомые достижения в развитии фундаментальных и прикладных научных исследований, успехи в разработке и внедрении новых научных решений и эффективных технологий, а также за укрепление научно-технического потенциала Украины В. В. Головко был награжден Почетным знаком отличия Национальной академии наук Украины «За научные достижения». В 2017 г. за цикл работ «Высокоэффективные сварочные материалы с улучшенными санитарно-гигиеническими показателями для сварки современных высокопрочных низколегированных сталей» В. В. Головко была присуждена премия им. И. К. Походни НАН Украины.

\section{Л.А. ВОЛГИНУ -80}

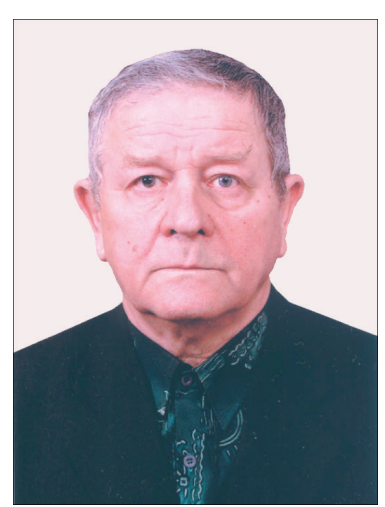

5 июля 2019 г. исполнилось 80 лет Волгину Леониду Александровичу - директору научно-инженерного центра «Материалообработка взрывом» с 1979 по 2018 гг.

Вся его трудовая и научная жизнь неразрывно связана с ИЭС им. Е.О. Патона. В 1963 г. после окончания КПИ он активно включился в работу Института, проявив при этом немалые инженерные и организаторские способности. С 1982 г., с момента создания Опытного производства ИЭС (ныне научно-инженерный центр «Материалообработка взрывом»), по 2018 г. являлся его руководителем. Это были годы появления и расцвета комплекса технологий материалообработки взрывом: сварки композитных материалов, резки кумулятивными зарядами и обработки взрывом с целью повышения служебных свойств сварных металлоконструкций.

За время его руководства была создана внушительная материальная база как для производства взрывных работ, так и для анализа результатов применения новых взрывных технологий. Построен участок оснащения кумулятивных зарядов и различных изделий специального назначения взрывчатыми веществами, построена уникальная мощная трубчатая камера, позволяющая подрывать заряд взрывчатого вещества до 200 кг.

В научном направлении (резка взрывом) НИЦ «Материалообработка взрывом» входит в число мировых лидеров. Результаты работ широко используются в авиакосмической и оборонной технике, на трубопроводном транспорте, в нефте- и газодобыче, при демонтаже крупногабаритных металлоконструкций, ликвидации последствий аварии на Чернобыльской АЭС, резке и утилизации конверсионной военной техники и во многих других уникальных работах.

Желаем юбиляру крепкого здоровья, бодрости и благополучия! 


\section{Подписка - 2019 на журнал «Автоматическая сварка» www.patonpublishinghouse.com/rus/journals/as Подписной индекс 70031}

\begin{tabular}{|c|c|c|c|}
\hline \multicolumn{2}{|c|}{ Украина } & \multicolumn{2}{c|}{ Зарубежные страны } \\
\hline на полугодие & на год & на полугодие & на год \\
\hline 990 грн. & 1980 грн. & 90 дол. США & 180 дол. США \\
\hline В стоимость подписки включена доставка заказной бандеролью. \\
\hline
\end{tabular}

Подписку на журнал «Автоматическая сварка» можно оформить непосредственно через редакцию или по каталогам подписных агентств: ДП «Преса», «Пресцентр», «Меркурий» (Украина); каталог зарубежных изданий «Белпочта» (Беларусь); каталог АО «Казпочта» Издания Украины (Казахстан); каталог «Газеты. Журналы» агентства «Роспечать», Объединенный каталог «Пресса России» (РФ).

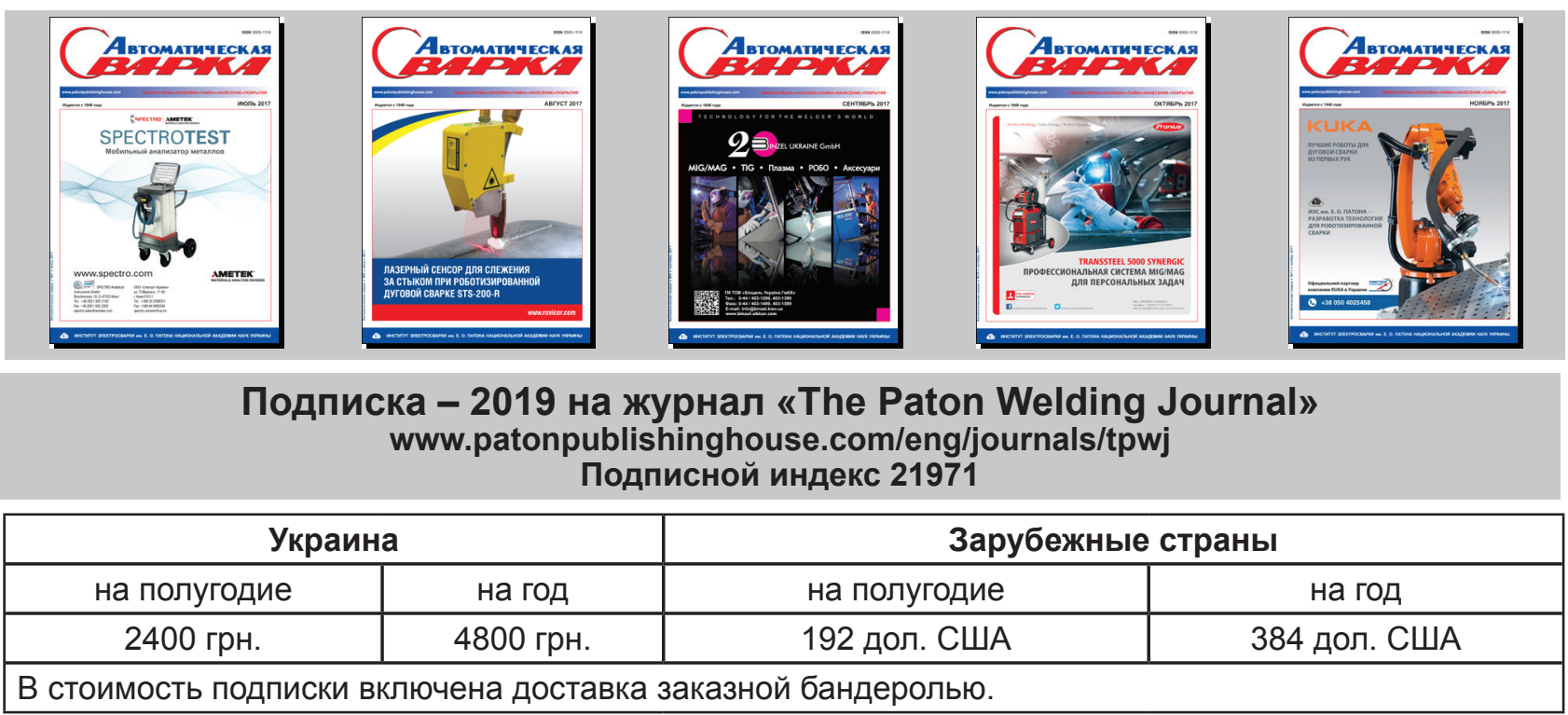

Журнал «Автоматическая сварка» в полном объеме переиздается на английском языке под названием

«The Paton Welding Journal». Журналы распространяются по редакционной подписке (тел./фракс: 38044 200-82-77, E-mail: journal@paton.kiev.ua).
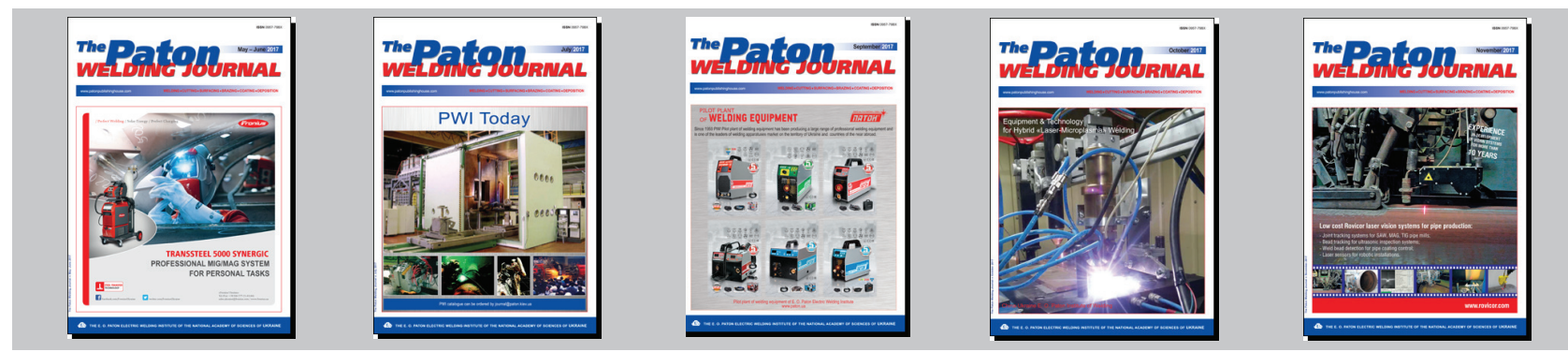

Правила для авторов, лицензионные соглашения, архивные выпуски журналов на сайте издательства www.patonpublishinghouse.com.

В 2019 г. в открытом доступе выпуски журналов с 2009 по 2017 гг. в формате *.pdf.

\section{Реклама в журналах «Автоматическая сварка» и «The Paton Welding Journal»}

Реклама публикуется на обложках и внутренних вклейках следующих размеров

- Первая страница обложки, 200×200 мм

- Вторая, третья и четвертая страницы обложки, $200 \times 290 \mathrm{~mm}$

- Первая, вторая, третья, четвертая страницы внутренней обложки, 200×290 мм

- Вклейка A4, 200×290 мм

- Разворот А3, 400×290 мм

- A5, $165 \times 130 \mathrm{~mm}$
Стоимость рекламы

- Цена договорная

- Предусмотрена система скидок

- Стоимость публикации статьи на правах рекламы составляет половину стоимости рекламной площади

- Публикуется только профильная реклама (сварка и родственные технологии)

- Ответственность за содержание рекламных материалов несет рекламодатель

Подписано к печати 11.06.2019. Формат 60×84/8. Офретная печать. Усл. печ. л. 9,04. Усл.-отт. 9,89. Уч.-изд. л. 10,24.

Печать ООО «ДИА». 